\title{
Develop and Test Fuel Cell Powered On-Site Integrated Total Energy Systems
}

\section{Final Report}

A. Kaufman

J. Werth

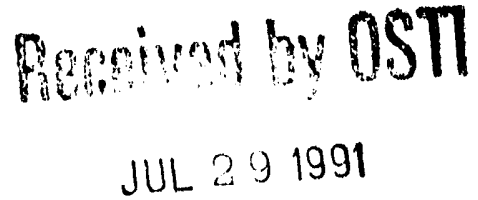

Decernber 1988

Work Performed Under Contract No.: DE-AC21-81MC24224

For

U.S. Department of Energy

Office of Fossil Energy

Morgantown Energy Technology Center

Morgantown, West Virginia

By

Engelhard Corporation

Research and Development Department

Edison, New Jersey

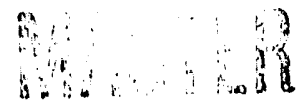




\section{DISCLAIMER}

This report was prepared as an account of work sponsored by an agency of the United States Government. Neither the United States Government nor any agency thereof, nor any of their employees makes any warranty, express or implied, or assumes any legal liability or responsibility for the accuracy, completeness or usefulness of any information, apparatus, product, or process disclosed, or represents that its use would not infringe privately owned rights. Reference berein to any specific commercial product, process, or service by trade name, trademark, manufacturer, or otherwise, does not necessarily constitute or imply its endorsement, recommendation, or favoring by the United States Government or any agency thereof. The views and opinions of authors expressed herein do not necessarily state or reflect those of the United States Government or any agency thereof.

This report has been reproduced directly from the best available copy.

Available to DOE and DOE contractors from the Office of Scientific and Technical Information, P.O. Box 62, Oak Ridge, TN 37831; prices available from (615)576-8401, FTS 626-8401.

Available to the public from the National Technical Information Service, U.S. Department of Commerce, 5285 Port Royal Rd., Springfield, VA 22161. 


\title{
Develop and Test Fuel Cell Powered On-Site Integrated Total Energy Systems
}

\author{
Final Report
}

\author{
A. Kaufman \\ J. Werth
}

Work Performed Under Contract No.: DE-AC21-81MC24224

\author{
For \\ U.S. Department of Energy \\ Office of Fossil Energy \\ Morgantown Energy Technology Center \\ P.O. Box 880 \\ Morgantown, West Virginia 26507-0880 \\ By \\ Engelhard Corporation \\ Research and Development Department \\ Menlo Park CN-28 \\ Edison, New Jersey 08818
}

December 1988 


\section{$\underline{\text { ABSTRACT }}$}

This report describes the design, fabrication and testing of a $25 \mathrm{~kW}$ fuel cell system aimed at stationary applications, and the technology development underlying that system. The $25 \mathrm{~kW}$ fuel cell ran at rated power in both the open and closed loop mode in the summer of 1988. Problems encountered and solved include acid replenishment leakage, gas cross-leakage and edge-leakage in bipolar plates, corrosion of metallic cooling plates and current collectors, cooling groove depth variations, coolant connection leaks, etc. 
Page

ABSTRACT

TABLE OF CONTENTS ii

LIST OF TABLES iv

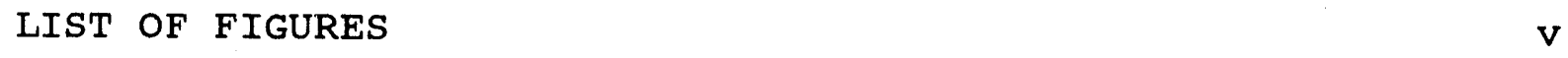

SUMMARY $\quad x$

INTRODUCTION 1

TASK I - 5kW POWER SYSTEM DEVELOPMENT 1

TASK II - ON-SITE SYSTEM APPLICATION ANALYSIS 2

TASK III - ON-SITE SYSTEM DEVELOPMENT 2

SUB-TASK III-1 LARGE STACK DEVELOPMENT 2

$4 \mathrm{~kW}$ Stacks 2

Full-Size Stacks $\quad 21$

SUB-TASK III-2 LARGE FUEL PROCESSOR DEVELOPMENT

Methanol Fuel Processor 43

Natural Gas Fuel Processor 46

SUB-TASK III-3 OVERALL SYSTEM ANALYSIS 51

SUB-TASK III-4 OVERATL SYSTEM DESIGN AND DEVELOPMENT 53

TASK IV - STACK TECHNOLOGY DEVELOPMENT

PERFORMANCE OPTIMIZATION

Catalysts 53

Reduced Cell IR-Loss $\quad 77$

Alternative Acid-Transport Layer $\quad 82$

Alternative Carbon Paper $\quad 96$ 
$\begin{array}{ll}\text { COST REDUCTION } & 96\end{array}$

Large Sub-Stacks Between Cooling Plates 96

Non-Metallic Cooling Plates 96

Current Collectors $\quad 100$

Bipolar Plates 103

$\begin{array}{ll}\text { IMPROVED RELIABILITY } & 103\end{array}$

Non-Metallic Cooling Plates 103

Bipolar Plates $\quad 110$

Carbon Supports 116

Cathode Wetproofing 116

Automated Electrolyte Replenishment 119

Gas and Coolant Manifolds 119

stack Start-Up and Shut-Down 119

Single Cell Life Test Fixtures 122

Dry Five-Cell Stack 122

$\begin{array}{ll}\text { TASK V - FUEL PROCESSING SUPPORT } & 125\end{array}$

TASK VI - IMPROVED ELECTROCATALYSTS 125 
Page

TABLE I Composition Analysis of Reformate Gas Sample

TABLE II Platinum Surface Area and Single-cell

Performance for $\mathrm{A}-1$ Catalyst Used as Cathode

66

TABLE III Short-Term Performance of Trimetaliic Cathode Catalysts in single cells

TABLE IV Immersion Corrosion of Carbon Fiber Materials

TABLE V Large Diameter Cooling Tubes

101

TABLE VI Corrosion Testing of Gold-clad wire in Concentrated Phosphoric Acid

TABLE VII Tafel Slopes for Bipolar Plate B-Element Materials 


\section{LIST OF FIGURES}

Page

FIGURE 1 Automated Electrolyte Management system 3

FIGURE 2 Engelhard Liquid-Cooled PAFC Stack 5

FIGURE 3 Cell Voltages in stack No. $1 \quad 7$

FIGURE $4 \quad \mathrm{H}_{2}$-Gain in Stack No. 1

FIGURE 5 Cell Voltages in stack No. 199

FIGURE $6 \quad$ Cell Voltages in stack No. $2 \quad 10$

FIGURE 7 Cell Voltages in stack No. 2 at 2928 Hours 11

FIGURE $8 \quad \mathrm{H}_{2}$-Gain in stack No. 2

FIGURE 9 Cell Configuration 14

FIGURE 10 ABA Bipolar Plate 15

FIGURE 11 Performance of $4 \mathrm{~kW}$ stack No. $3 \quad 16$

FIGURE 12 Voltage Loss at Bottom Current Collector 18

FIGURE 13 Performance of $4 \mathrm{~kW}$ Stack No. 3 at 3200 Hours 19

FIGURE 14 Performance Comparison in $4 \mathrm{~kW}$ stack No. $3 \quad 20$

FIGURE 15 Voltage Distribution in $4 \mathrm{~kW}$ stack No. 4

FIGURE 16 Performance History of $4 \mathrm{~kW}$ Stack No. $4 \quad 23$

FIGURE 17 Voltage Distribution in $4 \mathrm{~kW}$ Stack No. 4

FIGURE 18 Performance History of $4 \mathrm{~kW}$ stack No. 4

to 5000 Hours

$\begin{array}{lll}\text { FIGURE } 19 & 25 \mathrm{KW} \text { stack No. } 1 & 27\end{array}$

$\begin{array}{llll}\text { FIGURE } 20 & 25 \mathrm{~kW} \text { Stack No. } 1 & 28\end{array}$

FIGURE $2125 \mathrm{~kW}$ Stack No. $1 \quad 29$

FIGURE 22 Details of $25 \mathrm{~kW}$ Stack No. $1 \quad 30$ 


\section{LIST OF FIGURES}

\section{Page}

FIGURE 23 Teflon Cooling Tube End Connections 33

FIGURE 24 Cooling Tube End Connection 34

FIGURE 25 Voltage and Power Curves for $25 \mathrm{~kW} \mathrm{stack} 39$

FIGURE 26 Performance History of $25 \mathrm{~kW}$ Stack at Full Load 41

FIGURE 27 Stack Temperature Profiles $\quad 42$

$\begin{array}{lll}\text { FIGURE } 28 & \text { Natural Gas Reformer Schematic } & 47\end{array}$

$\begin{array}{lll}\text { FIGURE } 29 & \text { Natural Gas Reformer section } & 48\end{array}$

FIGURE 30 Reformer Burner Assembly 49

FIGURE 31 Reformer output $\quad 52$

FIGURE 32 Steady-Load Performance of Single-cell 54

with E-3 catalyst

FIGURE 33 Steady-Load Performance of single-cell 55

with E-3 Catalyst

FIGURE 34 Performance of Single-Cell with E-3 Catalyst 56

FIGURE 35 Performance of Single-Cell with E-3 Catalyst 57

FIGURE 36 Steady-Load Performance of Single-Cell with 58

E-7 Catalyst

FIGURE 37 Steady-Load Performance of single-cell with by

E-7 Catalyst

FIGURE 38 Performance of Single-Cell with E-7 Catalyst 60

FIGURE 39 Performance of Single-cell with E-7 Catalyst 61

FIGURE 40 Average Cell Voltages for Various Catalysts 63

in 1983 stack No. 3 


\section{LIST OF FIGURES}

Page

FIGURE 41 Voltammograms for Electrodes Before and

After Heat-Treatment

FIGURE 42 Effect of $900^{\circ} \mathrm{C}$ Catalyst Post-Trearment

FIGURE $43 \quad$ Single-Cell Performance stability 67

FIGURE 44 Heat-Treated A-2 Cathode Catalyst in 68

single-cell

FIGURE 45 E-8 Tri-Metallic Cathode in Single-Cell

FIGURE 46 E-3 Bimetallic Cathodes in Single-Cells 71

FIGURE 47 E-9 Trimetallic Cathode in single-cell 72

FIGURE $48 \quad$ E-3 Bimetallic Cathodes in Single-Cells 73

FIGURE 49 E-3 Bimetallic Cathode in Single-cell

FIGURE 50 Additional Single-Cell Test of E-3

Cathode Catalyst

FIGURE 51 Performance of E-8 Trimetallic Catalyst 78 in Single-cell

FIGURE 52 Open-Circuit Voltage of Stack No. 4 Rebuild 79

FIGURE 53 Open-Circuit Voltage of Stack No. 4 Rebuild 80 to 1600 Hours

FIGURE 54 Steady-Load Performance of Stack No. 4 Rebuild 81

FIGURE 55 Corrosion Behavior of Carbon Fiber Materials 84

FIGURE $56 \quad$ Single-Cell Performance stability 85

FIGURE 57 Performance stability of Five-Cell stack 86 with Alternative Acid-Transport Layer 


\section{LIST OF FIGURES}

Page

FIGURE 58 Performance of Five-Cell stack with 88 Alternative Acid-Transport Layer

FIGURE 59 Performance of Individual Cells in

Five-Cell stack

FIGURE 60 Performance of Five-Cell stack with

Alternative Acid Transport Layer to 5200 Hours

FIGURE 61 Performance of Individual Cells in

Five-cell stack to 5200 Hours

FIGURE 62 Performance Comparison in $4 \mathrm{~kW}$ stack No. 3

FIGURE 63 Performance Comparison in $4 \mathrm{~kW}$ stack No. 3 to 3200 Hours

FIGURE 64 Alternative Acid-Transport Layers in Single-Cells

FIGURE 65 Alternative Acid-Transport Layers in

Single-Cell to 3300 Hours

FIGURE 66 Single-cell Evaluation of Toray Carbon

Paper Substrates

FIGURE 67 Single-Cell Evaluation of Great Lakes

Carbon Papex Substrates

FIGURE 68 Second Single -Cell Evaluation of Great

Lakes Carbon Paper Substrates

FIGURE 69 Gold-clad Wire Current Collector concept

FIGURE 70 Corrosion Test of Gold-Clad wire 


\section{LIST OF FIGURES}

Page

FIGURE 71 Corrosion Current of Graphite Plates 106

FIGURE 72 Tafel Plots of Graphite Plates in 107

Phosphoric Acic

FIGURE 73 Temperature Distribution in stack No. $3 \quad 108$

FIGURE 74 Horizontal and Vertical Temperature 109

Distribution in stack No. 3

FIGURE 75 Steady-Load Performance of 1983 stack No. $3 \quad 111$

FIGURE 76 Corrosion Current of B-Elements 112

FIGURE 77 Test Circuit for ABA Plates. $3 \quad 114$

FIGURE 78 Electrical Test Fixture for ABA Platesor 115

FIGURE 79 Single-Cell Performance Stability 3200 Hours 117

FIGURE $80 \quad$ Cathode Hydrophobicity Evaluation in 118

Single-cell

FIGURE 81 Open-Circuit Voltage History of 1983

Stack No. 3

FIGURE 82 Automated Eiectrolyte Management system 123

FIGURE 83 Shut-Down/Start-Up stack 124

FIGURE 84 Acid Uptake of Dry Five-Cell Stack 126 


\section{SIJMNARY}

\section{INTRODUCTION}

Engelhard's objective under this concract was to contribute to the national fuel conservation program by developing a commercialiy viable and cost-effective on-site integrated energy system (OS/IES) powered by a phosphoric acid fuel cell. The fuel cell offers energy efficiencies in the neighborhood of 408 of the lower heating value of available fuels in the form of electrical energy. By utilizing the thermal energy generated for heating, ventilating, and air-conditioning (HVAC), a fuel cell OS/IES colild provide total energy efficiencies in the reighborhood of 80 . Also, the Engelhard fuel cell OS/IL'S, which was the objective of the present program, offers the important incentive of replacing importea oil with domestically produced fuel.

This report covers the period February 1984 through July 1988. The prededing periud from February 1981 throigh January 1984 was covered by the Interim Report dated octover 1984 and titled "Develop and Test Fuel Cell Powered on-site Integrated Total Energy systems." Together, these two reports are a complete set for the entire period of this contract.

Engelhard successfully completed the first two phases of this program by 1984. The culmination of the pre-commercialization program was to be the integration of the fuel cell system into a total energy system for multi-family residential and commercial buildings. The mandate of the Phase III effort was to develop a $25 \mathrm{~kW}$ integrated system and to identify a suitable type of application site.

A previously accomplished objective of phase III was the integration and testing of the $5 \mathrm{~kW}$ system whose components irad been developed during Phase II. In addition to the development and testing of this sub-scale system, scale-up activities had been carried out under Phase III. Throughout the program, continued technology development was carried out to insure that the periormance, reliability and cost objectives would be attained.

\section{TASK I - 5kW POWER SYSTEM DEVELOPMENT}

The objective of this task was the integration of the $5 \mathrm{~kW}$ components developed during the Phase II contract and operation of the ensuing $5 \mathrm{~kW}$ system. This task was described and discussed in the Feb. 81 - Jan. 84 Interim Report. 


\section{TASK II - ON-SITE SYSTEM APPLICATICIY ANALYSIS}

The purpose of this task was to develop an application model for on-site integrated energy systems (OS/IES). The work of this task was carried out under subcontract by Arthur D. Little, Inc. and was described in the Feb. 81 - Jan. 84 Interim Report.

\section{TASK III - ON-SITE SYSTEM DEVELOPMENT}

This task formed the core of the Phase III contract effort work under this task resulted in the breadboard design of a system for an on-site application. The power plant was designed for a rated output of $25 \mathrm{~kW}$ (electrical). The fuel processor and power conditioner were each $25 \mathrm{~kW}$ units. This task was broken down into four sub-tasks as follows:

III-1. Large Stack Development

III-2. Large Fuel Processor Development

III-3. Overall system Analysis

III-4. Overall system Design and Development

Sub-Task III-1 was the main focus of the contract activities under Task III during the period covered by this report.

\section{SUB-TASK III-1. LARGE STACK DEVELOPMENT}

This sub-task was directed toward the development of a $25 \mathrm{~kW}$ stack with cells of nominal two-ft ${ }^{2}$ area. The work was pursued via two parallel paths: (i) design, fabrication, and testing of the overall $25 \mathrm{~kW}$ stack along with its associated hardware; and (ii) development of two-ft ${ }^{2}$ (scaled-up) components, including verification testing using smaller (shorter) stacks rated at about 4 kilowatts each.

\section{A. 4-kW STACKS}

A key activity of the program has been long-term reliability testing of stacks incorporating state-of-the-art components and concepts. This effort served to verify their effectiveness and durability; alternatively, as problem areas (or potential problem areas) were exposed over the course of the program, modifications were carried out as appropriate to attain long-term durability.

This phase has consisted of the construction, testing and evaluation of $4 \mathrm{~kW}, 13$ inch $\times 23$ inch stacks. The first two stacks were essentially the same, each containing both the E-3 type and E-7 type of developmental cathode catalysts. Much of the testing utilized synthetic reformate fuel $\left(75 \% \mathrm{H}_{2}, 24 \% \mathrm{CO}_{2}, 1 \% \mathrm{CO}\right.$, moisturized to about $15 \% \mathrm{H}_{2} \mathrm{O}$ ). 


\section{4-kW STACK NO. 1}

This stack comprised 25 cells of the 13 inch $x 23$ inch size and six non-metallic cooling plates, spaced at five-cell intervals and at the ends of the stack. The stack ran in tye shut-down/ start-up mode through most of 1984, altogether logging about 7000 hours on load before it was permanently shut doin in early 1985 .

$$
\underline{4-\mathrm{kW}} \text { STACK NO. } 2
$$

The components used in this stack were essentially the same as those in Stack No. 1. It was placed on load in June of 1984 .

Stack No. 2 benefited from the installation of a protection control system designed to respond to and protect against factors that could damage the stack; such factors are loss of fuel, loss of air, loss of house power, over-temperature, and underremperature. The system provided a nitrogen purge through the fuel and air ports when an electrical power shut-down and attendant hydrogen supply interruption occurred overnight. No significant performance loss was sustained, whereas stack No. 1 and other stacks running in the laboratory without protection control systems had incurred noticeable losses.

$$
\text { 4-kW STACK NO. } 3
$$

Stack No. 3 contained 24 cells of the 13 inch $\times 23$ inch size. Several new technical features were included in this stack compared to the technology used in Stacks No. 1 and 2 . These included: (i) alternative bipolar plate B-element (separator) materials (polyetheretherketone and PFA Teflon) instead of polyet:hersulfone; ( $i$ ) new cathode catalyst types, including those held on more corrosion-resistant supports; (iii) an alternative acid-transport layer arrangement; and (iv) a single-component liquid coolant (triethylene glycol) in place of mineral oil. Also, there were six cells between cooling plates in this stack, instead of five.

This stack was shut down after 3200 hours for inspection of the PFA and PEEK type plates. The results were as follows:

- Stack performance was good throughout the test.

- The performance of the six-cell substack with alternative acid-transport layers was far superior to that of the other substacks.

- The PFA and PEEK type plates showed no tendency to delaminate. 
- The voltage loss at the gold-clad wire type current collector was less than $10 \mathrm{mV}$ at 161 $\mathrm{mA} / \mathrm{cm}^{2}$.

- The temperature spread among the cells in interior substacks was only about $7^{\circ} \mathrm{C}$, thus confirming the viability of six-cell substacks.

\section{$4-\mathrm{kW}$ STACK NO. 4}

This stack went on load in August 1987 for bench trials and evaluation of a Teflon-based graphite plate edge-sealing method. The stack ran for 5000 hours and was still working satisfactorily when it was shut down in March of 1988.

\section{B. FULL-SIZE STACKS}

\section{5-kW STACK NO. 1}

The stack components were mainly of the type that had been successfully used in the first pair of $4 \mathrm{~kW}$ stacks (above). Where appropriate in light of data obtained on the smaller stacks, design changes were carried out for the $25 \mathrm{~kW}$ stack. These involved an acid collection/drainage method to avoid corrosion at the bottom of the gas manifolds and a 0.0015 inch thick gold foil layer at the bottom current-collecting plate interface, to avoid both corrosion and the buildup of interfacial IR-loss.

The cells (175 of them, 13 inches $\times 23$ inches) were stacked using cooling plates at five-cell intervals. The acid-addition and compressive loading sequences were delayed by a series of unplanned stack heating system shut-downs. Interruptions due to external problems caused many temperature cycles (to and from room-temperature).

The stack was started on load in July 1985. The load was brought up gradually, as the cells appeared to be breaking-in very slowly. Acid was added (and taken up) in piecemeal fashion as the stack's load and temperature increased. Performance slowly improved during July and into August. The load was taken to $13 \mathrm{~kW}$ at a stack voltage of about $97 \mathrm{~V}$ with the temperature reaching $177^{\circ} \mathrm{C}$. Test results of using both hydrogen and reformate fuel, however, suggested that cell damage had occurred from the freezethaw cycles experienced before stack start-up.

A rebuild was completed in May 1986. The stack was integrated with the methanol reformer and ran until November 1986. Both the reformer and the overall system ran smoothly and trouble-free. Testing was suspended in mid-November 1986 to prepare for the installation of $25 \mathrm{~kW}$ stack No. 2 . 


\section{5-kW STACK NO. 2}

Substack assembly was completed in early December 1986, All substacks were installed in a special alignment fixture, and the overall assembiy of the stack was completed sy mid-month.

It was placed on load in January 1987. Initial performance was satisfactory at $45 \mathrm{~A}\left(27 \mathrm{~mA} / \mathrm{cm}^{2}\right)$ and $140^{\circ} \mathrm{C}$ with a voltage of $113 \mathrm{~V}(0.675 \mathrm{~V} / \mathrm{cel} 1)$. After various corrections to improve operation, electrical load was reapplied at the enc of January. The stack output then rose to $113.5 \mathrm{~V}(0.68 \mathrm{~V} / \mathrm{cell})$ at $97 \lambda_{1}$ $\left(58 \mathrm{~mA} / \mathrm{cm}^{2}\right)$.

The two bottom six-cell substacks were damaged during stack break-in and failed in mid-1987, so it was decided that those components would be replaced and other problems corrected at the same time. The stack was temporarily maintained in the hotstandby mode within the methanol-fueled system during rework preparations.

A rework was completed in May 1988. All substacks were reassembled using the reworked components and fresh electrode/electrolyte-matrix packages that had been prepared for this purpose. The stack was reassembled and was placed on load in May 1988.

The reworked stack ran successfully in the open-loop mode on steam-reformed natural gas as the load was brought up to maximum rated value. The power generated was $24.3 \mathrm{~kW}$ at $147 \mathrm{~mA} / \mathrm{cm}^{2}$ and at an average cell voltage of $0.613 \mathrm{~V}$.

The integrated system ran in the open-loop mode until the last week in July 1988; performance in general romained good. Two cell pairs, one in substack No. 6 and one in substack No. 27 (top substack), showed weakness, indicating likely flaws in the intervening bipolar plates. These substacks were bypassed.

Closed-loop operation (complete integration including anode vent gas from the stack being returned to the reformer burner) was approached during the last week of July 1988 and achieved in August 1988. The initial phase of this task involved simulating anode vent gas by throttling a portion of the reformate from the shift converter exit to the burner, so as to partially displace the natural gas that had been delivered to the burner in the openloop mode. This resulted in a burner feed gas with a hydrogen concentration in excess of $40 \%$, greater than typical concentrations in anode vent gas. There were no signs of flashback, despite concern about this based on preliminary tests results. 
In all, the test program lasted 10 weeks, 260 hours of which were on load, 125 hours at full load, 9 hours in the closed-loop mode. The initial performance was 0.605 to 0.610 volt per cell on averag:s at full load, as against a performance goal of 0.60 volt. The average cell voltage at the end of the test program was about 0.595 volt at fuil load. The estimated overall efficiency, including a $6 \%$ allowance for parasitic power, was $34.8 \%$.

The following was then ancomplished through these tests:

- Acceptable performance from a stack that was reouilt primarily from used components.

- Acceptable performance from the natural gas processing system designed and constructed by KTI and Engelhard.

- Performance from the power conditioner in line with specifications (e.g., $95 \%$ efficiency at full load).

- Demonstration of closed-loop operation (complete integration of. the system with anode vent gas being returned to the reformer burner) under conditions for which preliminary burner testing at Alzeta would have predicted flash-back.

- Effectiveness of control logic and control componerits in achieving smooth integrated system operation.

The following problems were addressed:

- Development of a leak in the acid-replenishment column, which led to irreversible damage to certain cells in the bottom substack; solution: (i) improved sealing technique for "spare" holes in column, and (ii) use of shorter, more frequent "on" times for the pump that circulates acid in response to signals from the timer.

- Development of cross-leakage in used bipolar plates in two separate substacks; solution: (i) use of polyetheretherketone (PEEK) B-element resin as the gas separator phase in bipolar plates, in place of PFA Teflon which was found to transport $\mathrm{H}_{2}$ about 30 times faster than PEEK, and (ii) more stringent quality control procedures for graphite plate elements (A-elements) to avoid large voids that could promote B-element permeation. 
'roo much heat loss in the reformer and the auxiliary components; solution: (i) improved thermal management through a more compact layout of the system, and (ii) upgraded thermal insulation of the reformer, auxiliary units, and connecting piping.

- A burner prone to flashback; solution: a non-porous radiative/convective burner design is being pursued by KTI.

\section{SUBTASK III-2 LARGE FUEL PROCESSOR DEVELOPMENT}

\section{A. METHANOL FUFL PROCESSOR}

A $50 \mathrm{~kW}$ methanol processing sub-system was constructed for use as a hydrogen generator for the $25 \mathrm{~kW}$ stack. Testing and troubleshooting of this unit started in May 1985.

The reformer ran at flow rates equivalent to $32 \mathrm{~kW}$, and essentially complete methanol conversion was obtained (>99\% based on condensate analysis). Also, outside analysis of an effluent gas sample showed satisfactory composition despite an unrecognized peak that showed up on the in-house chromatograph.

The methanol conversion efficiency fell during the early part of September 1985; this was attributed to an inadvertent overheating that occurred during a start-up. The reformer catalyst was taken out in lite september and new catalyst reduced in-situ.

The reformer resumed operation in early october 1985. However, the catalyst was rapidly deactivating. The methanol in the fuel storage tanks was analyzed and found to contain almost 1000 ppm of chlorinated hydrocarbons. The reformer catalyst was replaced after confirmation of contamination, reduced in situ and restarted in January 1986. The load was gradually increased and at the equivalent of $22 \mathrm{~kW}$, methanol conversion was essentially complete (>99\%).

The reformer continued to run at essentially complete methanol conversion during February 19\%5. The load range was extended to $30 \mathrm{~kW}$ equivalent and reformate fuel was supplied to the $25 \mathrm{~kW}$ stack at the February system restart. The reformer continued to work well both before and after a planned shutdown in March 1985 when it was subjected to minor upgrading and maintenance. 


\section{B. NATURAL GAS FUEL PROCESSOR}

Preliminary testing of the KTI-Engelhard natural gas processor began in November 1987. By February 1988, the reformer was running at $100 \%$ and $110 \%$ of rated throughput, each time with two separate steam/fuel ratios ( 3.0 and 3.5 moles $\mathrm{H}_{2} \mathrm{O} /$ mole $\mathrm{C}$ ).

The reformer-burner fuel feed requirement as a function of process gas feed rate was determined in May of 1988 . The results showed, as expected, that the ratio of burner fuel to process gas increased as the load fell from $100 \%$ to $30 \%$ of rated; however, the increase was small.

The natural gas reformer ran in the integrated mode in July 1988 , as described for $25 \mathrm{~kW}$ stack No. 2 , above.

\section{SUBTASK III-3 OVERALL SYSTEM ANALYSIS}

The Physical Sciences Inc. subcontract was completed in 1983. (See Interim Report for the period Feb. 1981 - Jan. 1984).

\section{SUBTASK III-4 OVERALL SYSTEM DESIGN AND DEVELOPMENT}

The Trane Co. completed work in 1983 under its subcontract to Engelhard. The main conclusions of Trane's study with respect to the HVAC sub-system and the utilization of waste heat were summarized in the 1981-1984 Interim Report.

\section{TASK IV - STACK TECHNOLOGY DEVELOPMENT}

The purpose of this task was to investigate new materials and component concepts through bench-testing and stack trials. The criteria for selecting activities under this task were the prospects for improved performance, reduced costs, or improved reliability.

\section{A. PERFORMANCE OPTIMIZATION}

\section{CATALYSTS}

A performance comparison between two developmental cathode catalysts (E-3 and E-7) was provided through the testing of stacks No. 1 and 2 in the 1984 series. The average disparity of performance between the two catalysts was about $15 \mathrm{mV}$ for stack No. 1 (about 4000 hours) and about $10 \mathrm{mV}$ for stack No. 2 (about 2900 hours), each in favor of $\mathrm{E}-7$. 
Long-term single-cell evaluations were carried out for the E3 bimetallic catalyst. One cell was shut down after 4180 hours due to cross-leakage associated with the single-cell hardware, while the other continued on test. The surviving cell had an output of $0.674 \mathrm{~V}$ IR-free $\left(\mathrm{H}_{2}-\mathrm{air}\right)$ at $161 \mathrm{~mA} / \mathrm{cm}^{2}$ and $191^{\circ} \mathrm{C}$ at shutdown after 5032 hours on load.

Another E-3 cathode gave $0.695 \mathrm{~V}$ IR-free $\left(\mathrm{H}_{2}-\mathrm{air}\right)$ at $161 \mathrm{~mA} / \mathrm{cm}_{2}$ and $191^{\circ} \mathrm{C}$ after 2400 hours on load.

A single-cell test of an E-8 trimetallic cathode catalyst showed high peak activity with an IR-free cell voltage of $0.734 \mathrm{~V}$ at $161 \mathrm{~mA} / \mathrm{cm}^{2}$ and $191^{\circ} \mathrm{C}$ on hydrogen-air after about 200 hours. At about 1900 hours, it was running at about $0.716 \mathrm{~V}$ when a fuel supply interruption caused a severe drop in output. Thereafter, the cell improved by about $9 \mathrm{mV}$ (to $0.694 \mathrm{~V}$ ), and testing continued for a total of 2400 hours.

\section{REDUCED CELL IR-LOSS}

1983 Stack No. 4 showed some progress with cell IR-loss. The individual cells had losses ranging from 30 to $36 \mathrm{mV}$ at $161 \mathrm{~mA} / \mathrm{cm}^{2}$, an improvement of about $15 \mathrm{mV}$ over typical earlier stacks.

New approaches to IR-loss reduction were also tested in single-celis. Two approaches that showed encouraging results (24$26 \mathrm{mV}$ IR-loss a $161 \mathrm{~mA} / \mathrm{cm}^{2}$ ) are described in Appendix 1 .

\section{ALTERNATIVE ACID-TRANSPORT LAYER}

A five-cell, 10.7 inch $\times 14$ inch stack was constructed in October 1985 with an alternative acid-transport layer configuration. Even though one cell ran well below par, the average cell voltage was $0.64 \mathrm{~V}$ at $161 \mathrm{~mA} / \mathrm{cm}^{2}$ and $191^{\circ} \mathrm{C}, \mathrm{H}_{2}-\mathrm{air}$. The stack opencircuit voltage was quite high at $4.53 \mathrm{~V}$. The average cell IR-loss was about $40 \mathrm{mV}$ at $161 \mathrm{~mA} / \mathrm{cm}^{2}$.

This acid-transport layer was also tested in one of the sixcell substacks of $4 \mathrm{~kW}$ stack No. 3. These cells performed much better than those in other substacks.

\section{ALTERNATIVE CARBON PAPER}

Single cells were tested to evaluate new carbon paper electrode substrate materials from both Toray and Great Lakes; these were replacement candidates for the stackpole material (PC-206), which was no longer available from stackpole. 
A cell in which Toray paper was evaluated showed good stability through the first 3300 hours; but it decayed rapidly during November 1987 , losing $36 \mathrm{mV}$ at $161 \mathrm{~mA} / \mathrm{cm}^{2}$ (to $0.665 \mathrm{~V}$ IRfree). It was shut down at the end of November (after 4000 hours on load) because of a heating pad failure.

\section{B. COST REDUCTION}

\section{LARGER SUBSTACKS BETWEEN COOLING PLATES}

The use of five cells per cooling plate instead of four in 1983 stacks No. 1,2 and 3 produced satisfactory thermal profiles. Consequently, all subsequent stacks were made with $20 \%$ fewer cooling plates. Later, the number of cells per cooling plate was increased to 6 , for a total reduction in cooling plates of $33 \%$.

\section{NON-METALLIC COOLING PLATES}

A simpler way to connect the cooling tubes to the coolant manifold, using Swagelok fittings with Teflon ferrules and a direct connection without a viton gasket between the tubes and the fittings, was included in the $25 \mathrm{~kW}$ stack.

\section{CURRENT COLLECTORS}

The concept of current collectors made of base metal coated with a protective and electronically conductive carbon-polymer composite was set aside. While they have performed reasonably well, irregular flaws occurred often enough to cast doubt on the achievability of a five-year life for this component. Of special concern was the fact that a corroded or delaminated current collector (at the bottom) could not be repaired or replaced without taking the entire stack apart.

A current collector concept based on the use of standard gold-clad base metal wire made at Engelhard's Plainville plant was studied in 1985. This design was substantially cheaper than an earlier current collector made of gold foil. Analysis of a design based on this type of collector showed that the cost of the recoverable gold cladding would be well under $\$ 10 / \mathrm{kW}$ in a $25 \mathrm{~kW}$ stack. Electrical tests on small graphite coupons showed an IRdrop of under 100 millivolts (out of a stack voltage of over 100 volts).

\section{BIPOLAR PLATES}

A method of cutting graphite plates with a kerf loss of about $0.030 "$ was demonstrated by the Glaiss Fab Co. This technique, when scaled up, could greatly reduce the material cost of the stack. 
Lower cost graphite materials were evaluated for possible use in bipolar plates. An inexpensive material designated "PH", supplied by the SERS Division of Pechiney S.A., was tested for corrosion resistance. The corrosion tests showed $\mathrm{PH}$ to be superior to both graphite materials previously used ("HLM" from Great Lakes Carbon and "940G" from Airco-Spear).

\section{IMPROVED RELIABILITY}

\section{NON-METALLIC COOLING PLATES}

The heat-transfer performance of the non-metallic cooling plates in 1983 stack No. 3 exceeded the goals established for this component. The effective temperature difference (log mean) from the cooling fluid to the adjacent cell element was only $9.4{ }^{\circ} \mathrm{F}$, compared to the goal of $18^{\circ} \mathrm{F}$. The corresponding overall heat transfer coefficient was $116 \mathrm{Btu} / \mathrm{hr}-\mathrm{ft}^{2}-\mathrm{O}_{\mathrm{F}}$.

\section{BIPOLAR PLATES}

Wetproofing of $A B A$ bipolar plates requires that the fluoropolymer wetproofing compound be cured at elevated temperature, preferably at $550^{\circ} \mathrm{F}\left(288^{\circ} \mathrm{C}\right)$. However, the presence of PES B-elements in the finished $A B A$ plate required a lower curing temperature to avoid a loosening of the film bond. Films of poly-etheretherketone (PEEK) and PFA Teflon, unlike PES, do not soften at $288^{\circ} \mathrm{C}$. Tests to det $\epsilon$ mine the suitability of these two materials as substitute B-elements showed electrical and sealing properties as good as those of PES. Later tests showed that PEEK was superior to PFA Teflon in its impermeability to hydrogen (See Task III-B).

\section{CARBON SUPPORTS}

A cathode using E-3 catalyst on Gulf Acetylene Black was tested in a single-cell. This cell showed a peak performance of $0.711 \mathrm{~V}$ IR-free $\left(161 \mathrm{~mA} / \mathrm{cm}^{2}, 191^{\circ} \mathrm{C}, \mathrm{H}_{2}\right.$-air) after about 600 hours, but an optimum electrode structure had clearly not yet been achieved with this catalyst support. Performance was $0.686 \mathrm{~V}$ (same conditions) at shut-down after about 2650 hours on load.

\section{CATHODE WETPROOFING}

A single-cell test in which variations in cathode hydrophobicity were examined was carried out. After having peaked at about $0.705 \mathrm{~V}$ (IR-free, $161 \mathrm{~mA} / \mathrm{cm}^{2}, 191^{\circ} \mathrm{C}$ ) at 1900 hours, the cell was putting out $0.676 \mathrm{~V}$ after 4600 hours. The voltage dropped significantly at about 2000 hours, after which the cell ran stably for quite a while at about $0.680 \mathrm{~V}$. A house power failure (resulting in a hot no-load condition) after about 4600 hours caused a severe loss in performance; nevertheless, the overall stability was encouraging. 


\section{AUTOMATED ELECTROLYTE REPLENISHMENT SYSTEM}

1983 Stack No. $3(11-\mathrm{cell}, 10.7$ in. $x 14$ in.) ran successfully for 6900 hours on load with the automated electrolyte replenishment system.

\section{GAS AND COOLANT MANIFOLDS}

Testing of the two $198425-c e l l$ stacks showed the need for improvements in protecting the manifolds. The proposed improvements fell into three categories: better corrosion resistance, periodic removal of excess phosphoric acid, and replaceability of vulnerable parts.

Corrosion resistance was improved by switching, wherever possible, from Teflon-coated aluminum, copper, brass, or low carbon steel to Teflon-coated Type-316 stainless steel, a material which has shown much better resistance to phosphoric acid corrosion than any of the other base metals used so far. The coolant manifolds were further protected by moving them from the hydrogen exhaust manifold to the hydrogen inlet manifold in the $25 \mathrm{~kW}$ stack.

Acid tends to accumulate at the bottoms of the gas manifolds, causing corrosion. To prevent this, the manifold bottoms of the $25 \mathrm{~kW}$ stack were provided with removable trays from which acid could be periodically drained.

\section{STACK START-UP ANR SHUT-DOWN}

Thermal cycling of single-cells was successfully carried out. The main precautions shown to be required were a continued supply of $105 \% \mathrm{H}_{3} \mathrm{PO}_{4}$ and the presence of an electrical load at any temperature higher than $270^{\circ} \mathrm{F}$.

A five-cell, 10.7" $x 14 "$ stack designed to examine the effectiveness of the shut-down/start-up procedure ran for about 2200 hours, including six room-temperature shut-downs. The loss from peak performance was similar to the loss pattern in stacks not subjected to periodic shut-downs.

\section{SINGLE-CELL LIFE TEST FIXTURES}

A fixture in which the aluminum body was replaced by Type 316 stainless steel was used in single-cell testing to allow more meaningful long-term tests to be conducted without the complicating effects of fixture corrosion. This fixture showed no sign of corrosion after a test of 1800 hours duration and two additional, shorter-term runs. 


\section{DRY FIVE-CELL STACK}

A dry five-cell stack ( 10.7 inches $x 14$ inches) was built to test the feasibility of acid-filling after assembly. The stack ran for about 500 hours on load. On hydrogen fuel, the average cell voltage was about $0.64 \mathrm{~V}\left(161 \mathrm{~mA} / \mathrm{cm}^{2}, 191^{\circ} \mathrm{C}\right)$, close to what is typical for the standard stack construction (as was the average open-circuit voltage of $0.86 \mathrm{~V}$ per cell). This result was encouraging, suggesting that far greater flexibility is feasible in the assembly and transport of fuel cell stacks.

\section{TASK V - FUEL PROCESSING SUPPORT}

The intent of this task was to provide background data to support the design and construction of an optimized methanol fuel processor under Task III. The results were described and discussed in Engelhard's Interim Report for the period February 1981 - January 1984 .

\section{TASK VI - IMPROVED ELECTROCATALYSTS}

Developmental electrocatalyst formulations were prepared under Engelhard sponsorship. These were provided to the main program and results reported under Task IV.

\section{ACHIEVEMENTS, CONCLUSIONS AND RECOMMENDATIONS}

Four stacks rated at $4 \mathrm{~kW}$ each were designed, built and tested under this contract. They ran for 7,000 hours, 2,900 hours, 3,200 hours and 5,400 hours respectively. Stack No. 4 was still working satisfactorily when it was shut-down in March of 1988. These stacks have validated the reliability and cell-spacing of the nonmetallic cooling plates, the latter having been increased stepwise from 4 cells to 6 cells, with consequent cost, volume and weight savings and no degradation in temperature uniformity. The stacks also demonstrated improved performance (no delamination) from advanced B-element materials (P.E.E.K. and P.F.A.), improved cathode catalysts, corrosion-resistant catalyst supports, a greatly improved acid-transport layer design, a reliable and durable gold-clad wire current collector, and a superior, Teftonbased graphite plate edge-sealing method.

The 25-kW stack design, fabrication and testing successfully demonstrated the complete integration of the fuel cell stack with the natural gas reformer, the control system, the power conditioner and the various other system components. specifically, closed loop operation was achieved without the predicted flash-back, the logic and control components worked smoothly and reliably and the power conditioner was $95 \%$ efficient 
at full load. Other achievements of the $25 \mathrm{~kW}$ stack tests included an improved sealing technique for the acid replenishment column, a more responsive control technique for the acid pump and the demonstration of P.E.E.K. as greatly superior to PFA in minimizing cross-leakage of gas across the B-elements.

The methanol reformer was demonstrated at $30 \mathrm{~kW}$ equivalent with greater than 998 methanol conversion and was successfully used in generating reformate fuel for the $25 \mathrm{~kW}$ stack.

Two superior cathode catalysts, the E-7 bimetallic catalyst and the E-8 trimetallic catalyst, demonstrated IR-free performance well above those available from earlier catalysts: $0.674 \mathrm{~V}$ and $0.716 \mathrm{~V}$ respectively, both at $161 \mathrm{~mA} / \mathrm{Cm}^{2}$ and $191^{\circ} \mathrm{C}$.

A reduction of about $15 \mathrm{mV}$ in cell IR loss was achieved during the period covered by this report.

other achievements included improved cooling tube connections, a cheaper graphite ( $\mathrm{PH}$ by Pechiney) of acceptable performance in bipolar plates, an improved method of wetproofing bipolar plates based on curing at $288^{\circ} \mathrm{C}$, a more stable hydrophobic agent for cell cathodes, more corrosion-resistant designs (based on Teflon-coated 316 stainless steel) for gas and coolant manifolds, the addition of removable trays to get rid of acid collecting at the bottom of the stack, the successful demonstration of damage-free stack thermal cycling, the ciesign of corrosion-resistant single-cell test fixtures, and the demonstration of a method for acid-filling cells after (instead of before) assembly, which could greatly ease the assembly and transport of stacks.

The conclusions and recommendations resulting from this work are as follows:

1. The li.quid-based cooling system has shown superior performance, reliability and economics and should be adopted for most types of phosphoric acid fuel cells.

2. Both methanol and natural gas reforming are feasible anode fuel sources for phosphoric acid fuel cells. Methanol is more practical for vehicles, natural gas more econmical for on-site systems.

3. Bi-metallic and tri-metallic cathode catalysts should be used in preference to single-metal catalysts.

4. There should be six cells between cooling plates.

5. B-elements should be made of P.E.E.K. in preference to P.F.A. or P.E.S. 
6. Bottom current collectors should use gold-clad wire rather than copper or aluminum coated with carbon paper.

7. Edge seals should be made of electrostatically sprayed Teflon rather than baked graphite adhesive.

8. A-elements should be made of inexpensive $\mathrm{PH}-t y p e$ graphite.

9. Wet-proofing of bipolar plates should be done at about $290^{\circ} \mathrm{C}$.

10. Stack metal hardware exposed to phosphoric acid should be made of Teflon-coated 316 stainless steel.

11. Long-lived $25 \mathrm{~kW}$ stacks should be achievable based on tine performance observed and technological improvements achieved under this contract.

12. The thermal management and thermal insulation of the reformer, auxiliary units and conrecting piping should be improved.

13. A non-porous radiative/convective burner should be designed to avoid flashback. 


\section{INTRODUCTION}

Engelhard's objective under the present contract was to contribute to the national fuel conservation program by developing a commercially viable and cost-effective on-site integrated energy system (OS/IES) powered by a phosphoric acid fuel cell. The fuel cell offers energy efficiencies in the neighhorhood of $40 \%$ of the lower heating value of available fuels in the form of electrical energy. By utilizing the thermal energy generated for heating, ventilating, and air-conditioning (HVAC), a fuel cell os/IES could provide total energy efficiencies in the neighborhood of $80 \%$. Also, the Engelhard fuel cell OS/IES, which was the objective of the present program, offers the important incentive of replacing imported oil with domestically produced fuel.

This report covers the period February 1984 through July 1988. The preceding period from February 1981 through January 1984 was covered by the Interim Report dated October 1984 and titled "Develop and Test Fuel Cell powered on-site Integrated Total Energy systems." Together, these two reports are a complete set for the entire period of this contract.

Engelhard successfully completed the first two phases of this program by 1984. The first involved the construction and testing of a $5 \mathrm{~kW}$ fuel cell stack and the study of fuel cell applications where industrial waste hydrogen is the fuel source; the second was devoted to stack technology upgrading, fuel processor development based on methanol, and development of a $5 \mathrm{~kW}$ integrated system. The culmination of the pre-commercialization program was to be the integration of the fuel cell system into a total energy system for multi-family residential and commercial buildings. The mandate of the Phase III effort was to develop a $25 \mathrm{~kW}$ integrated system and to identify a suitable type of application site. A previously accomplished objective of Phase III was the integration and testing of the $5 \mathrm{~kW}$ system whose components had been developed during phase II. In addition to the development and testing of this sub-scale system, scale-up activities had also been previously carried out under Phase III. Throughout this program, continued technology development was carried out to insure that the performance, reliability and cost objectives would be attained.

\section{TASK I - 5kW POWER SYSTEM DEVELOPMENT}

The objective of this task had been the integration of the $5 \mathrm{~kW}$ components developed during the Phase II contract and operation of the ensuing $5 \mathrm{~kW}$ system. This work was described and discussed in the February 1981-January 1984 Interim Report. 


\section{TASK II - ON-SITE SYSTEM APPLICATION ANALYSIS}

The purpose of this task had beento develop an application model for on-site integrated energy systems. The model considered fuel availability, costs, building types and sizes, power distribution requirements (electrical and thermal), waste heat utilization potential, types of ownership of the os/IES, and grid connection vs. stand-alone operation. The work of this task was carried out under subcontract by Arthur D. Little, Inc. (ADL) and was summarized in the February 1981 - January 1984 Interim Report.

\section{TASK III - ON-SITE SYSTEM DEVELOPMENT}

This task formed the core of the Phase III contract effort. Work under this task resulted in the breadboard design of a system for an on-site application. The power plant was designed for a rated output of $25 \mathrm{~kW}$ (electrical). The task was broken down into four subtasks as follows:
III-1. Large Stack Development
III-2. Large Fuel Processor Development
III-3. Overall system Analysis
III-4. Overall System Design and Development

\section{SUB-TASK 1. LARGE STACK DEVELOPMENT}

$$
\text { A. 4-kW STACKS }
$$

A key activity of the program has been long-term reliability testing of stacks incorporating state-of-the-art components and concepts. This effort served to verify their effectiveness and durabili'cy; alternatively, as problem areas (or potential problem areas) were exposed over the course of the program, modifications were carried out as appropriate to attain long-term durability. The stacks included an automated electrolyte management system developed during the period covered by the February 1981 - January 1984 interim period (see Figure 1). This system pumps acid from an overflow reservoir to a return reservoir where it is distributed to the individual cells by means of carbon sponges and graphite wicks sheathed in Teflon tubing. 


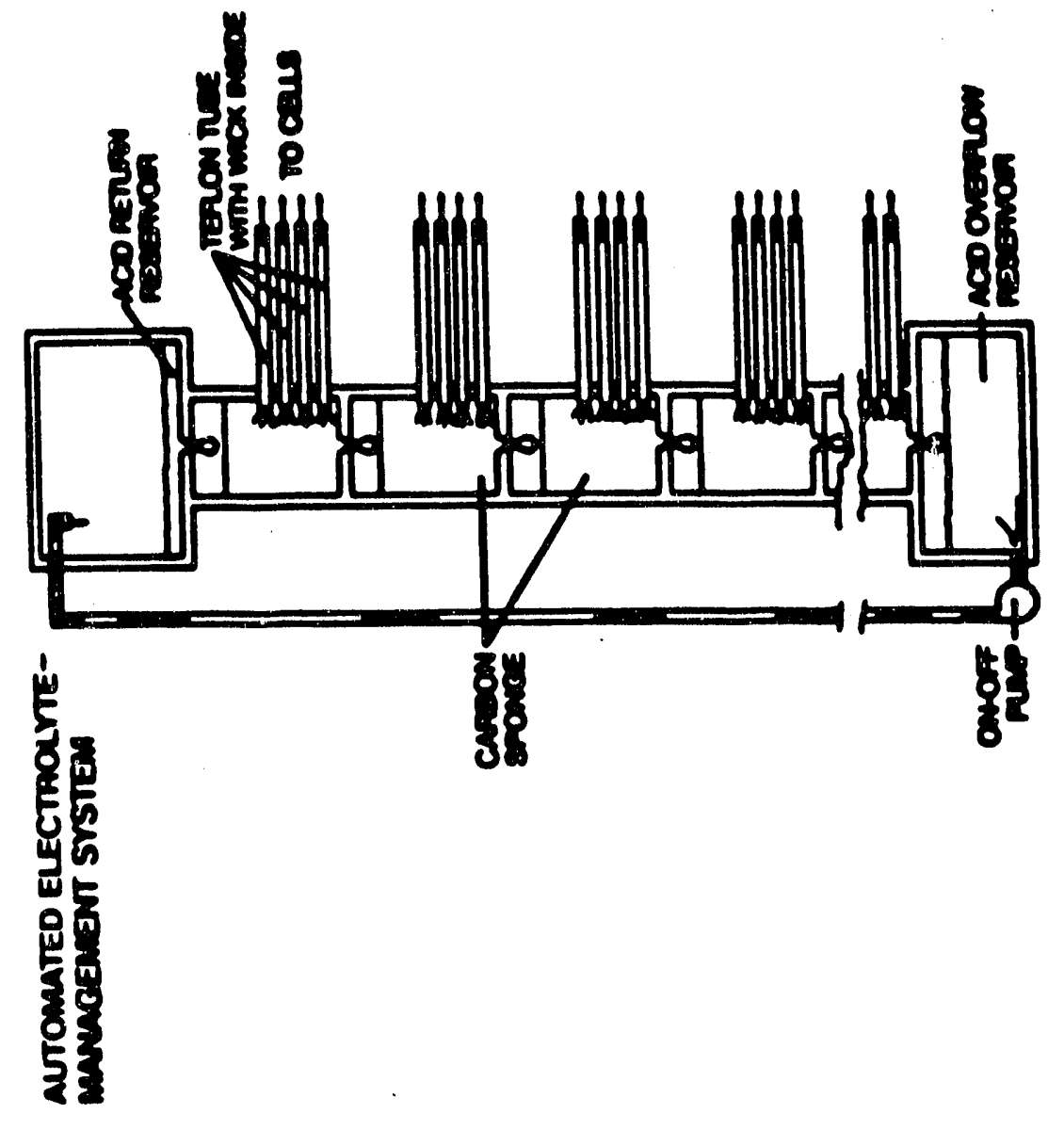

E

足

1

$-1$

崩 
This phase has consisted of the construction, testing and evaluation of $4 \mathrm{~kW}, 13$ inch $\times 23$ inch stacks. The first two stacks were essentially the same, each concaining both the E-3 type and E-7 type of developmental cathode catalysts. Much of the testing utilized synthetic reformate fuel $\left(75 \% \mathrm{H}_{2}, 24 \% \mathrm{CO}_{2}, 1 \% \mathrm{CO}\right.$, moisturized to about $\left.15 \% \mathrm{H}_{2} \mathrm{O}\right)$. These 25 -cell stacks were shut down after operating for about 7000 and 8400 hours on load, respectively.

Stack No. 3 contained 24 cells of the 13 inch $\times 23$ inch size. E-3 cathode catalyst was used except in one substack in which E-2 (Pt-only) cathode catalyst was used.

In addition, several advanced features were put into this stack, including:

(i) six-cell substacks, instead of five-cell;

(ii) one six-cell substack with alternative acid-transport layers;

(iii) one substack each with PFA Teflon and polyetheretherketone (PEEK) bipolar plate B-elements;

(iv) current collector based on gold-clad wire.

This stack was shut down after 3200 hours for inspection of the PFA and PEEK plates.

$4 \mathrm{~kW}$ Stack No. 4 (24 cells, 13 in. $\times 23$ in.) included an advanced graphite plate edge-sealing method that had been developed in the laboratory. Its design closely reflected that of $25 \mathrm{~kW}$ stack No. 2. It comprised four six-cell substacks along with three inboard cooling plates which separate pairs of substacks. The two outboard substacks used the E-7 bimetallic cathode catalyst, while the two inboard substacks used the E-3 bimetallic cathode catalyst. The stack ran on both hydrogen and synthetic reformate fuels.

The stack was shut down at the beginning of March 1988 following a D.O.E. managerial decision.

\section{$4 \mathrm{~kW}$ STACK NO. 1}

This stack comprised 25 cells of the 13 inch $\times 23$ inch size and six non-metallic cooling plates, spaced at iive-cell intervals and at the ends of the stack. (See Figure 2:. The stack was operated in the shut-down/start-up mode through most of 1984, altogether logging about 7000 hours on load before it was shut down in early 1985. 


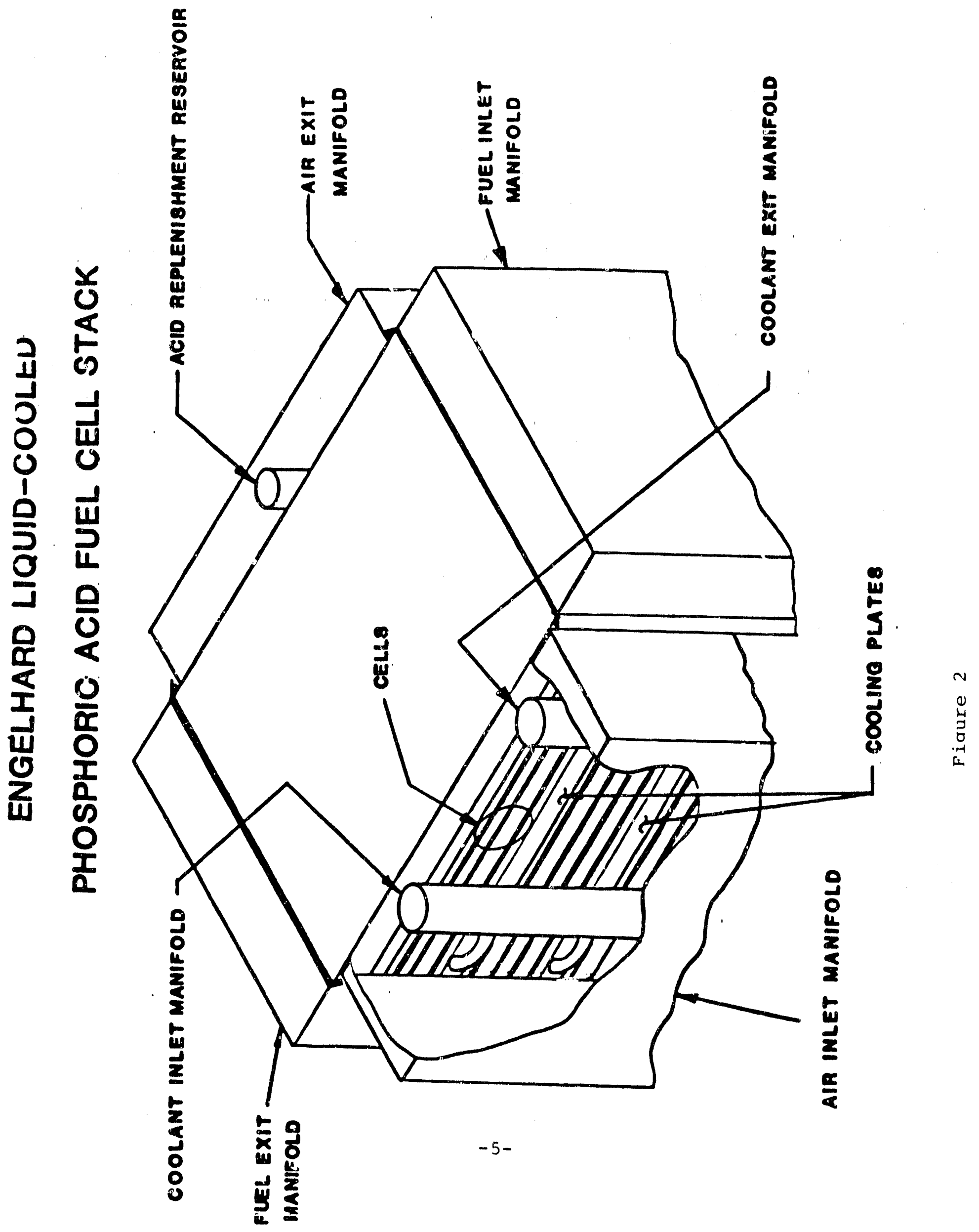


Operation on synthetic reformate fuel $\left(75 \% \mathrm{H}_{2}, 24 \% \mathrm{CO}_{2}, 1 \%\right.$ CO: moisturized to about $10 \% \mathrm{H}_{2} \mathrm{O}$ ) started in August of 1984 . The performance level was $0.59 \mathrm{~V}$ per cell on average at $161 \mathrm{~mA} / \mathrm{cm}^{2}$, reformate-air. The distributions of cell voltages and $\mathrm{H}_{2}$-gains are shown in Figures 3 and 4 , respectively.

The stack-protection control system was applied to this stack in september 1984. However, before the over-temperature/undertemperature sensor was installed, an unexplained overnight coolant pump stoppage caused an excessive stack temperature of about $500^{\circ} \mathrm{F}$.

The stack was returned to its normal operating temperature the following morning when the coolant pump restarted normally. The stack suffered no overt damage, but because of the overheating, it was shut down for inspection of manifold gaskets, coolant distribution hoses, etc. A minor leak was found in a Viton reactant gas manifold gasket; this gasket section was replaced, and the stack restarted and returned to normal load.

The performance loss suffered by stack No. 1 from having overheated was surprisingly small. However, there was evidence of increasing $\mathrm{H}_{2}$-gain in several cells during october (especially Cell No. 24; see Figure 5). This apparently reflected some electrolyte flooding of the anodes (loss of wetproofing effectiveness).

\section{$4 \mathrm{~kW}$ STACK NO. 2}

The components used in this stack were essentially the same as those in Stack No. 1. It was placed on load in June of 1984. The initial terminal voltage was $15 . \mathrm{sV}$ at $161 \mathrm{~mA} / \mathrm{cm}^{2}$; the initial distribution of voltages is shown in Figure 6 . Much of the testing used synthetic reformate fuel $\left(75 \% \mathrm{H}_{2}, 24 \% \mathrm{CO}_{2}, 1 \% \mathrm{CO}\right.$, moisturized to about $15 \% \mathrm{H}_{2} \mathrm{O}$ ).

stack No. 2 was running at $0.55 \mathrm{~V}$ on average at $161 \mathrm{~mA} / \mathrm{cm}^{2}$ (reformate-air) after having been on load for a total of 8400 hours when it was shut down in August 1985. At that time, it was torn down and its components and hardware were inspected. This inspection caused several changes and alternative approaches to be made in stack No. 3 .

The distribution of cell voltages and $\mathrm{H}_{2}$-gains at 2900 hours is shown in Figures 7 and 8 , respectively.

Stack No. 2 benefited from the installation of a protection control system designed to respond to factors that could damage the suck and, in doing so, to minimize the potential damage; such factors are loss of fuel, loss of air, loss of house power, over-temperature, and under-temperature. The system provided a 

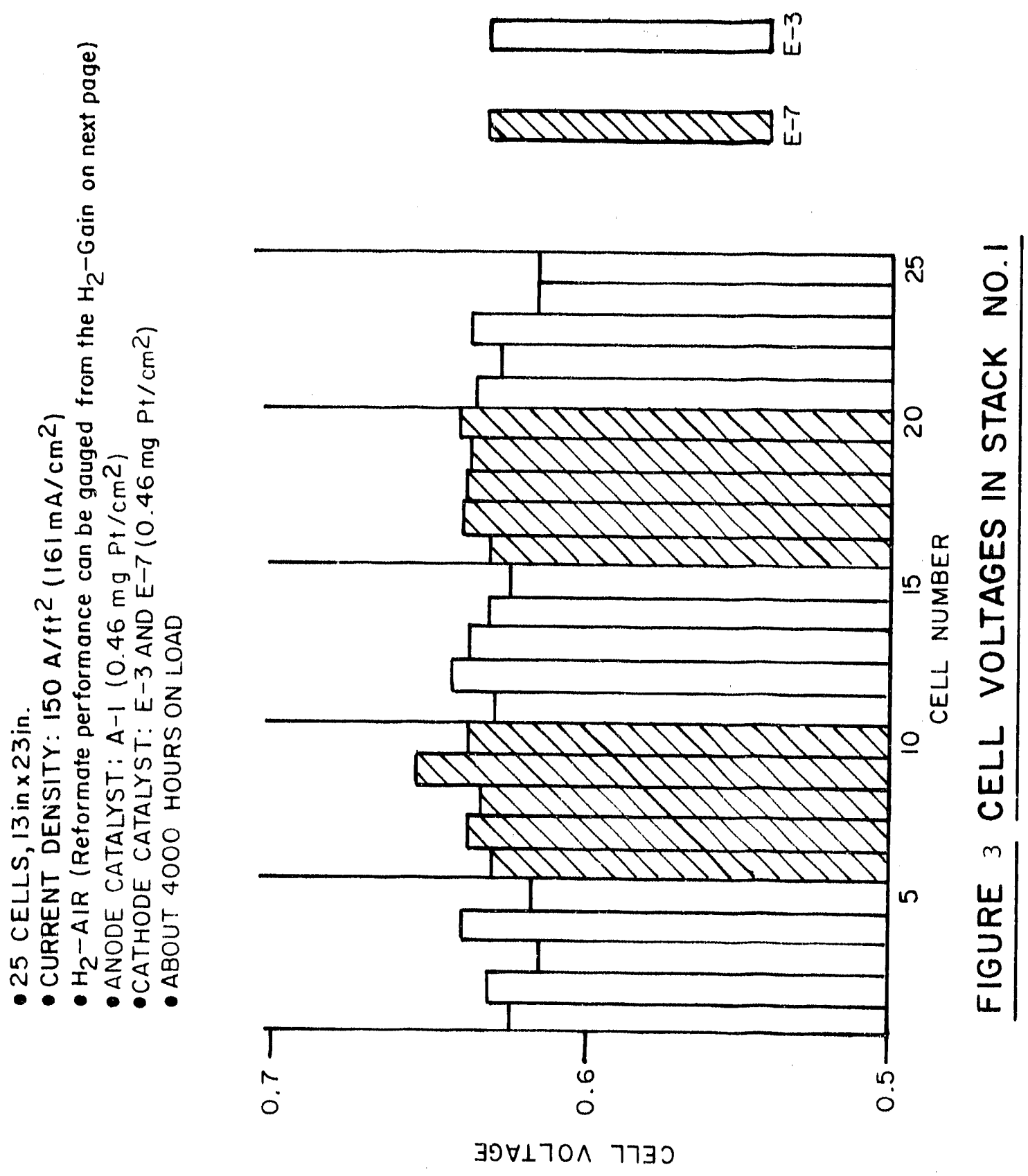

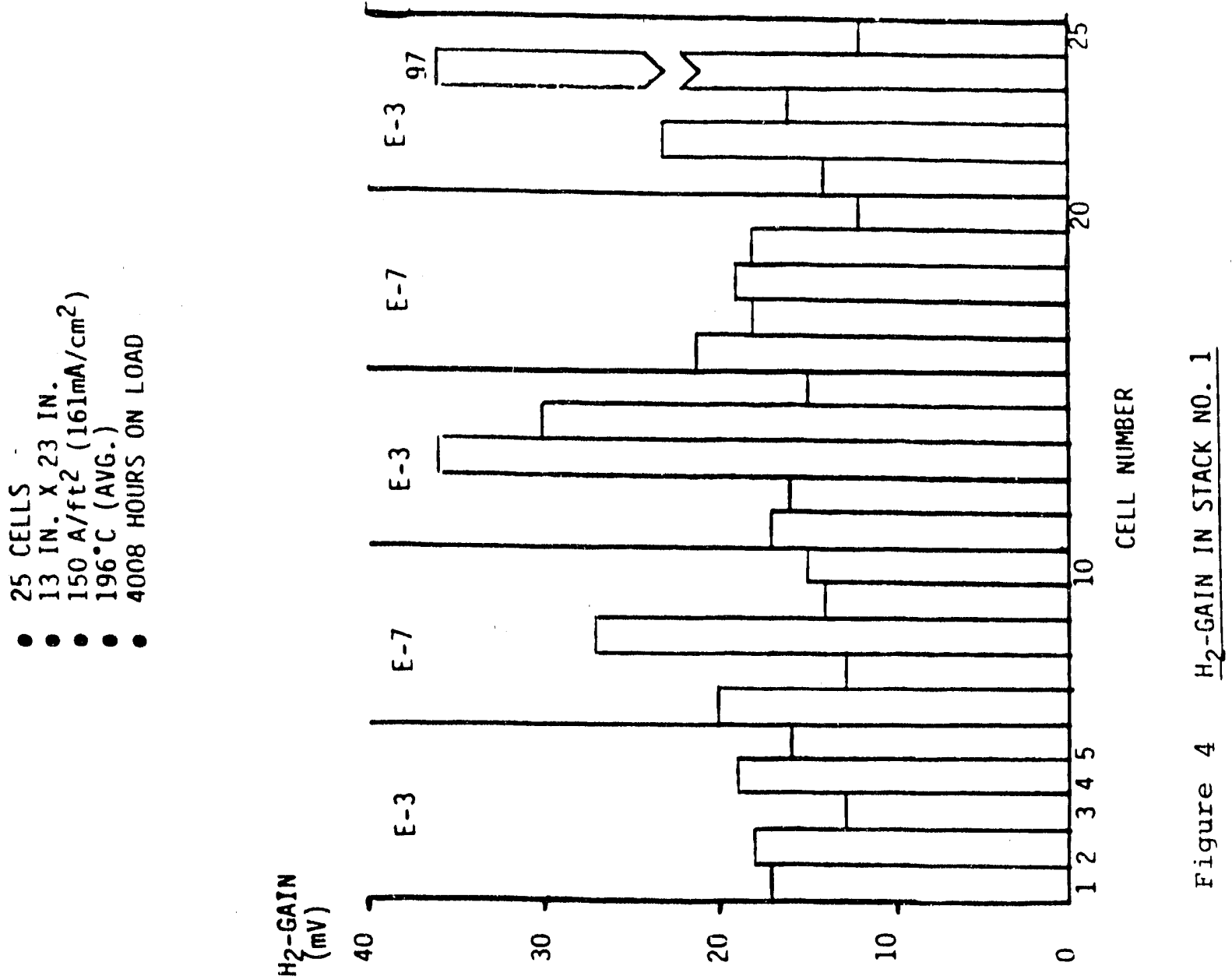

$-8-$ 

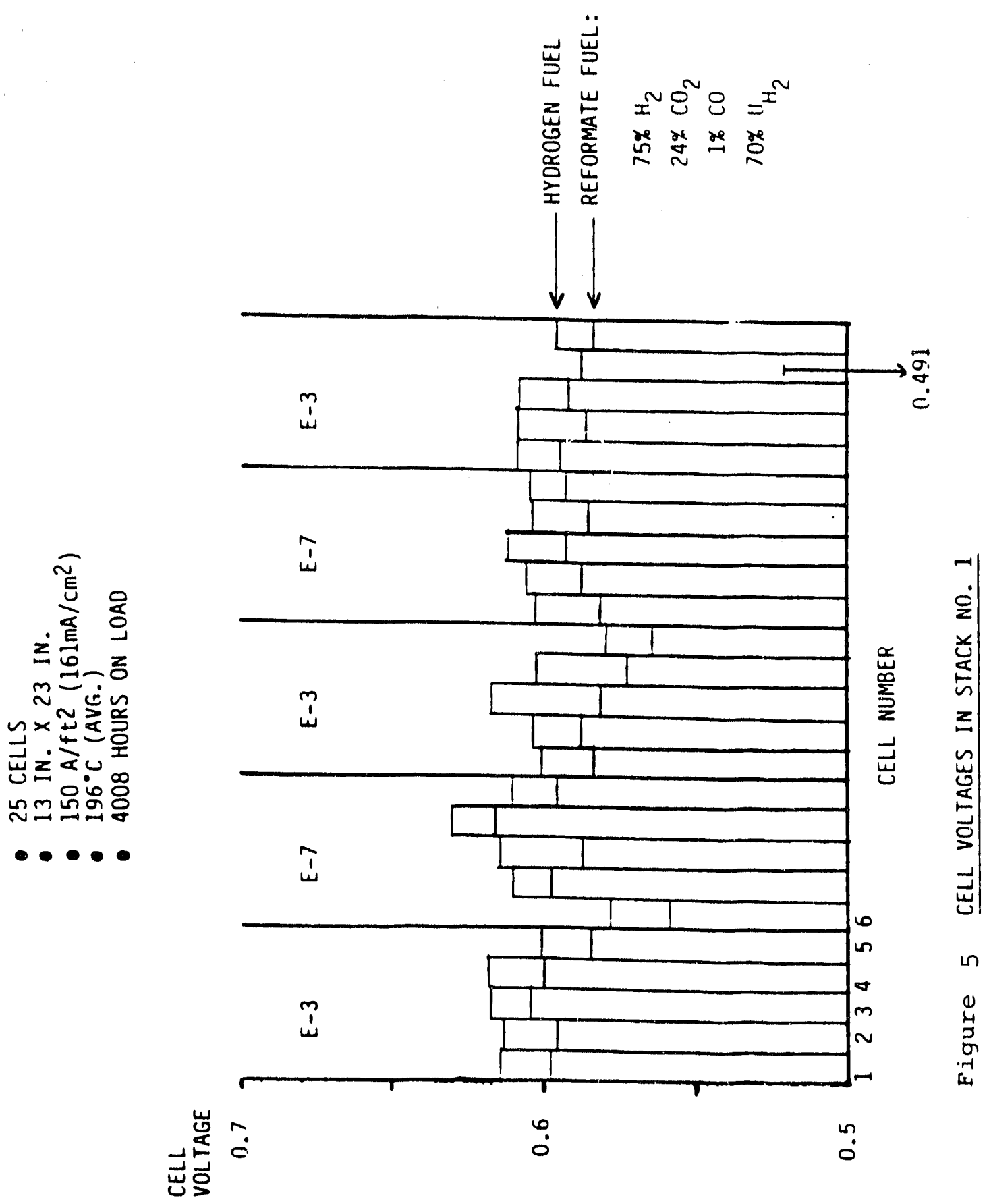


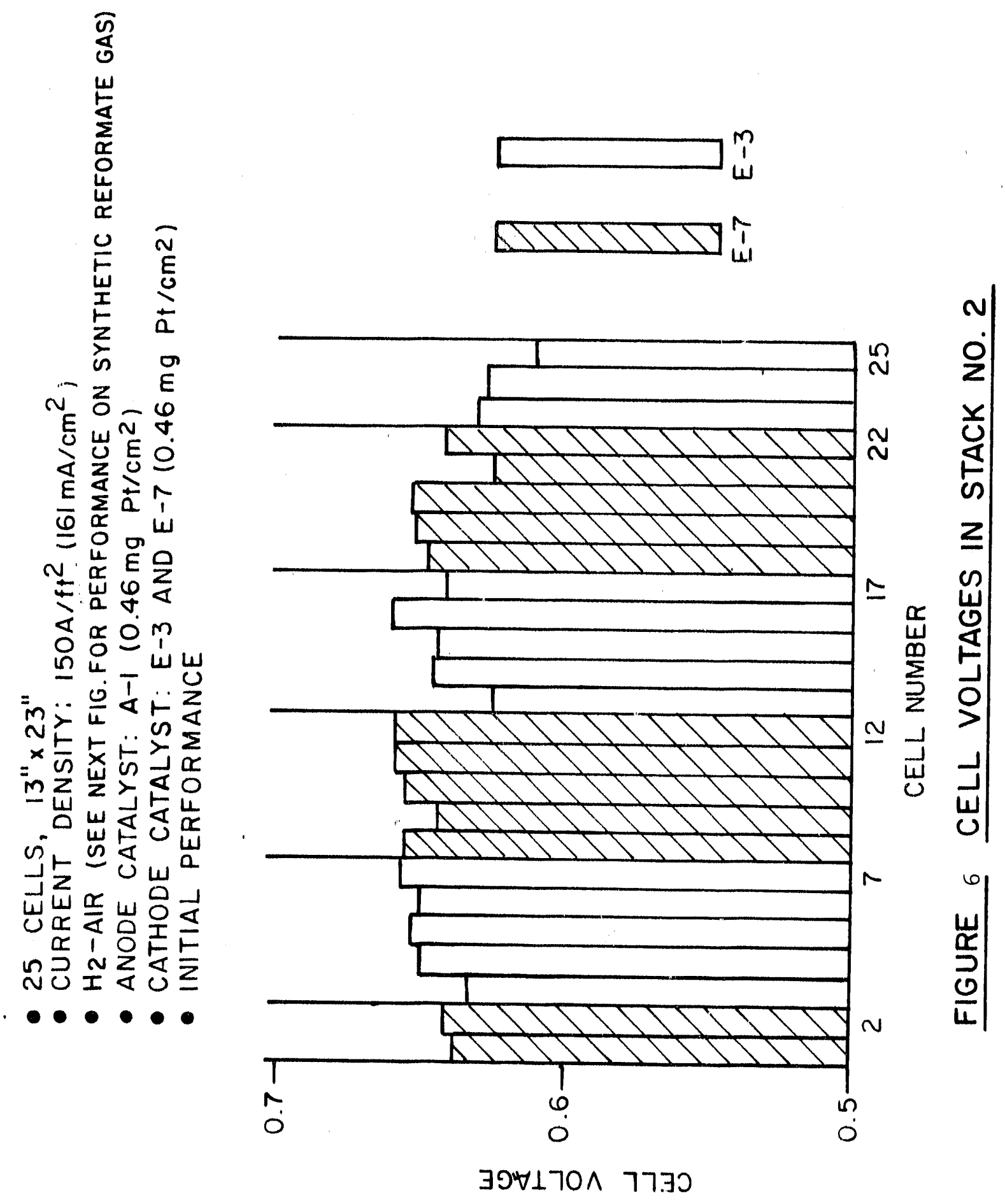



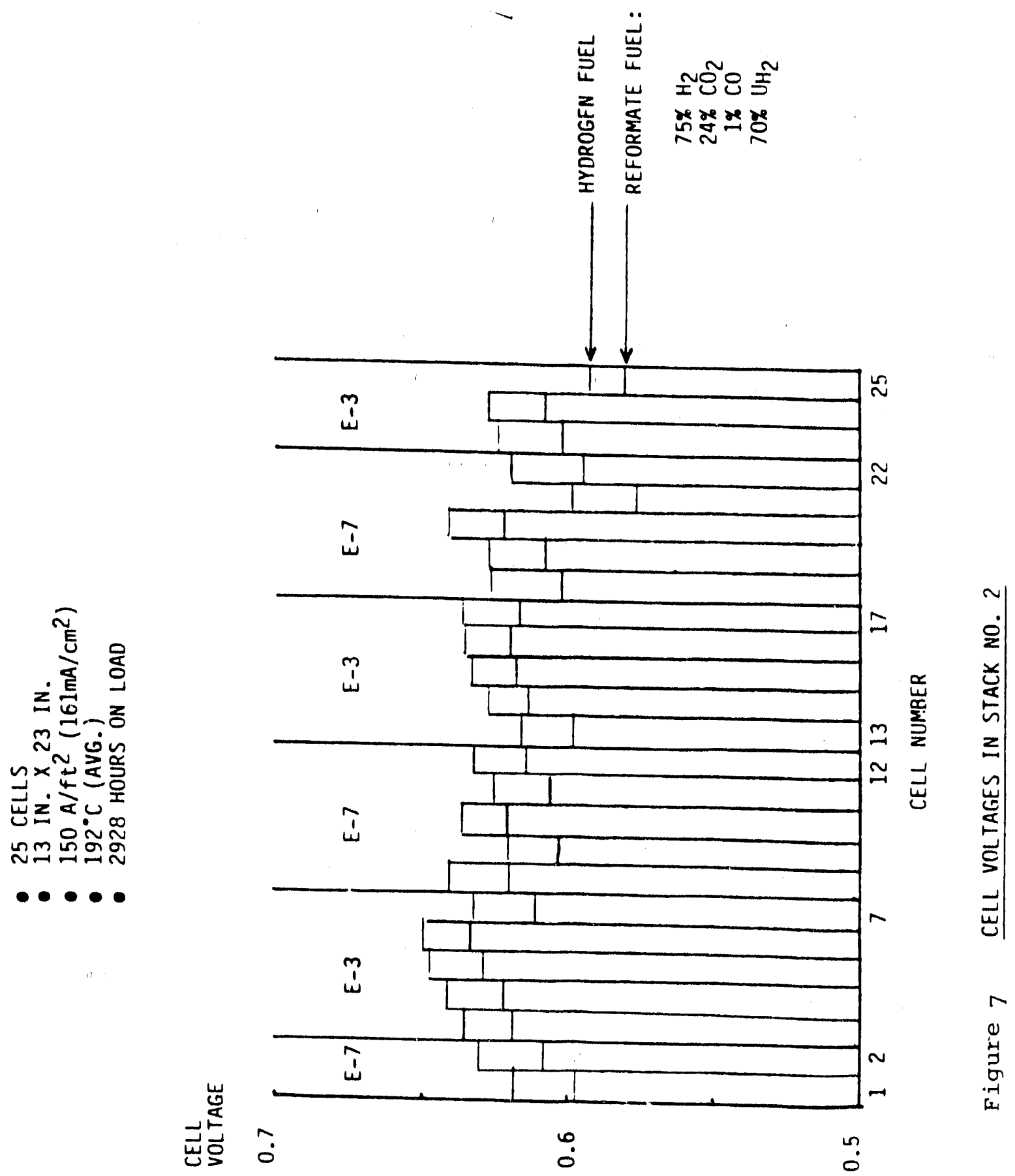

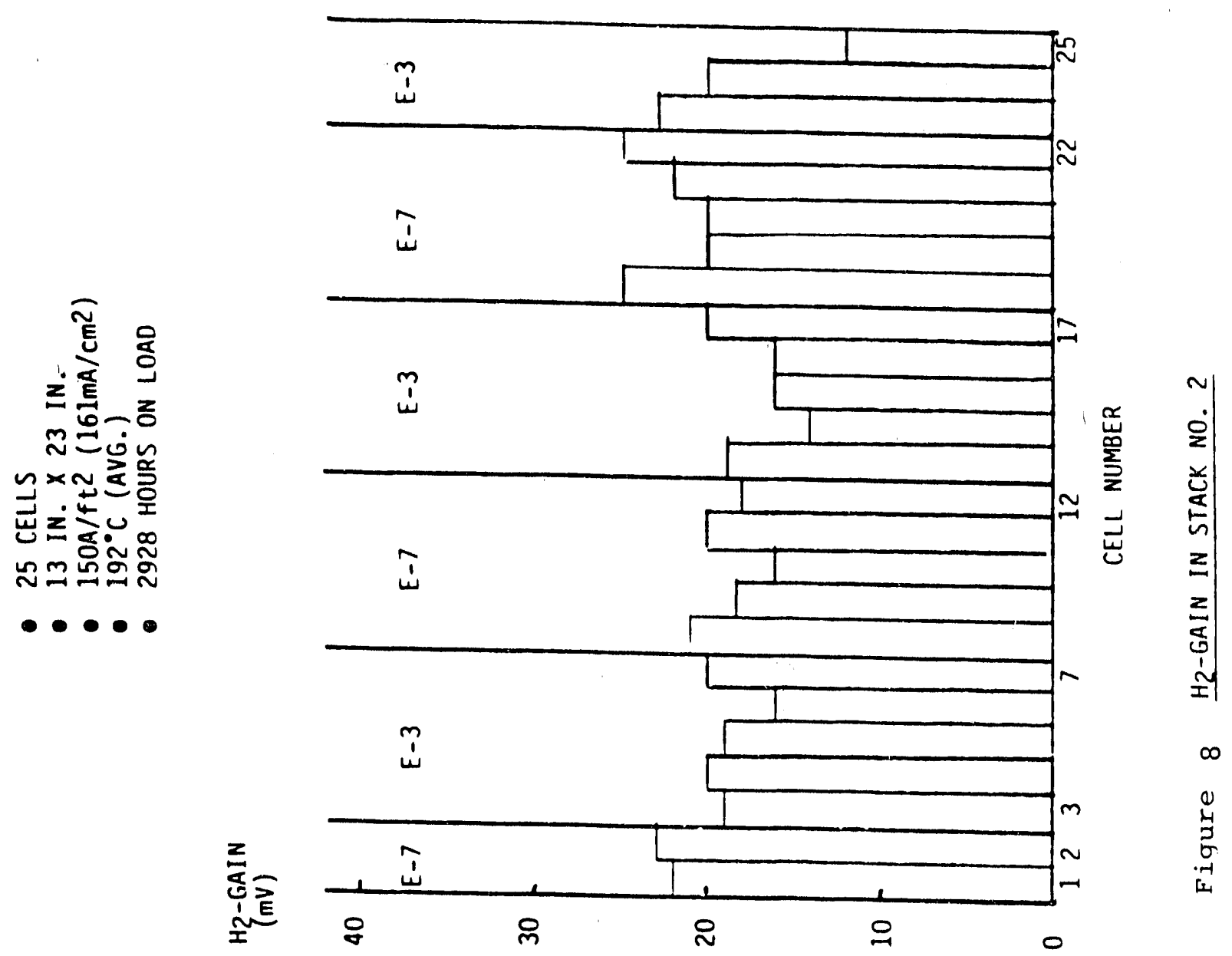
nitrogen purge through the fuel and air ports whenever an electrical power shutdown and attendant hydrogen supply interruption occurred overnight. No significant performance loss was sustained, whereas stack No. 1 and other stacks running in the laboratory without protection control systems incurred noticeable losses.

Both stacks 1 and 2 were adversely affected by a hydrogen supply interruption in August 1984. This incident, caused by an unexpected gas delivery lapse over a weekend, resulted in both a hot no-load condition ( $1-1 / 2$ hours) and a water soak (because the fuel humidification stream remained on during that time). Stack No. 1 lost about $10 \mathrm{mV}$ per cell on average as a result of this. About $2 \mathrm{mV}$ of this loss was attributable to an increase in $\mathrm{H}_{2}$-gain.

Stack No. 2 also suffered some damage even though its stackprotection control system had been operational, providing a nitrogen purge in place of both the fuel and air feeds upon a loss of hydrogen. However, the continuing flow of water in the humidification stream apparently caused some soaking, especially as the temperature of the stack dropped. The performance loss resulted wholly from an increase in $\mathrm{H}_{2}$-gain (to an average of 20$21 \mathrm{mV}$ per cell, compared to 10-11mV earlier).

In October 1984, both stacks 1 and 2 went through a controlled shut-down (via the stack-protection control systems) in response to a simulated upset. An automatic restart was also carried out for both stacks, and in each case there was no apparent performance loss.

\section{$4 \mathrm{~kW}$ STACK NO. 3}

Stack No. 3 contained 24 cells of the 13 inch $x 23$ inch size. Several new technical features were included in this stack. compared to the technology used in stacks No. 1 and 2 . These included: (i) alternative bipolar plate B-element (separator) materials (polyetheretherketone and PFA Teflon) instead of polyethersulfone; (ii) new cathode catalyst types, including those held on more corrosion-resistant supports; (iii) an alternative acid-transport layer arrangement; and (iv) a single-component liquid coolant (triethylene glycol) in place of mineral oil. Also, there were six cells between cooling plates in this stack, instead of five. Figures 9 and 10 illustrate the cell concepts.

At $161 \mathrm{~mA} / \mathrm{cm}^{2}$, with the stack temperature ranging between $181^{\circ} \mathrm{C}$ and $191^{\circ} \mathrm{C}$, the stack voltage-versus-time plot after 1600 hours is shown in Figure 11. One cooling plate interface showed an erratic IR-drop during December 1985; it was traced to the inadvertent use of a K-element pair with undersized groove depths. The stack was shut down for one day for disassembly and rework of these elements; it was then reassembled and returned to load. 


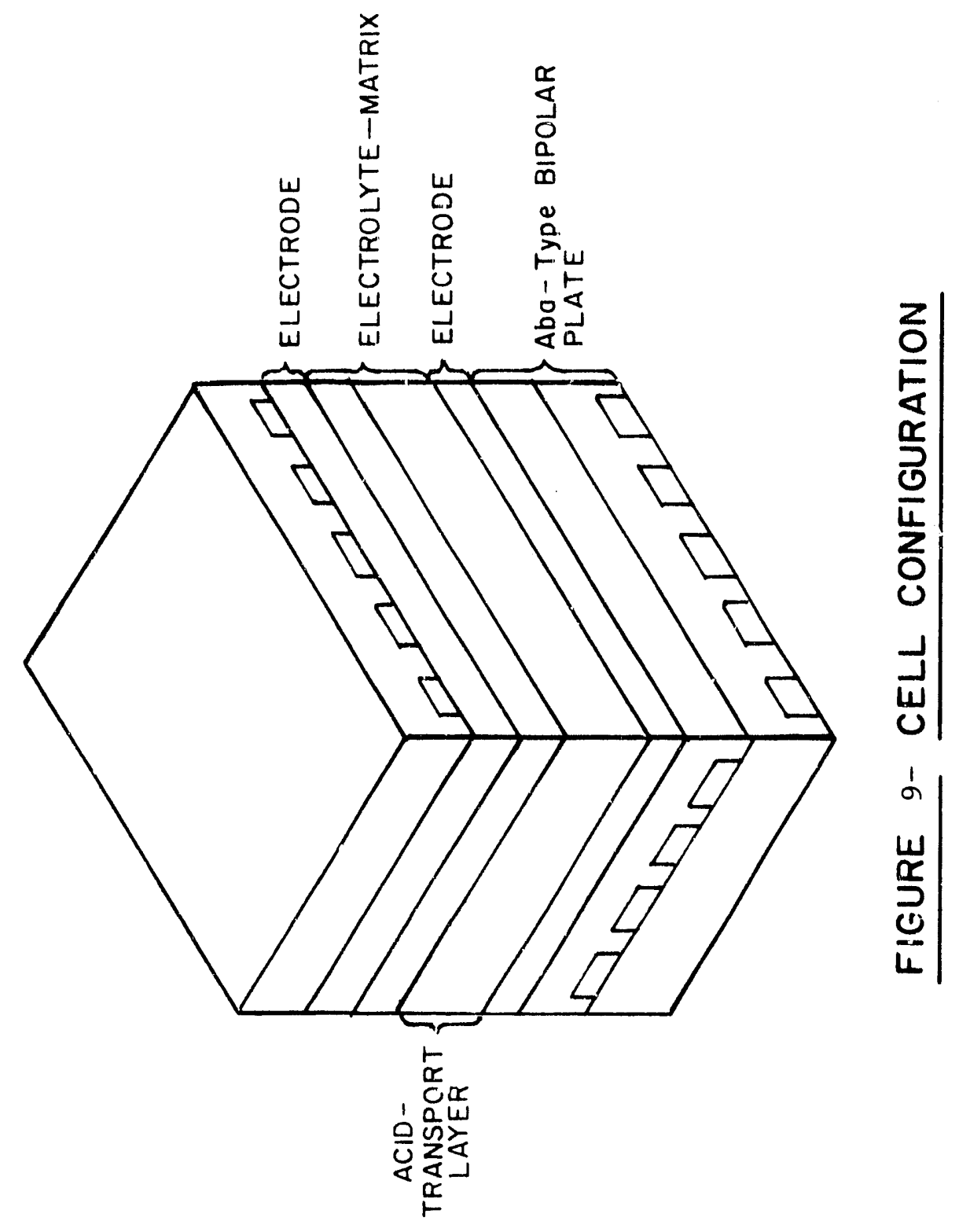



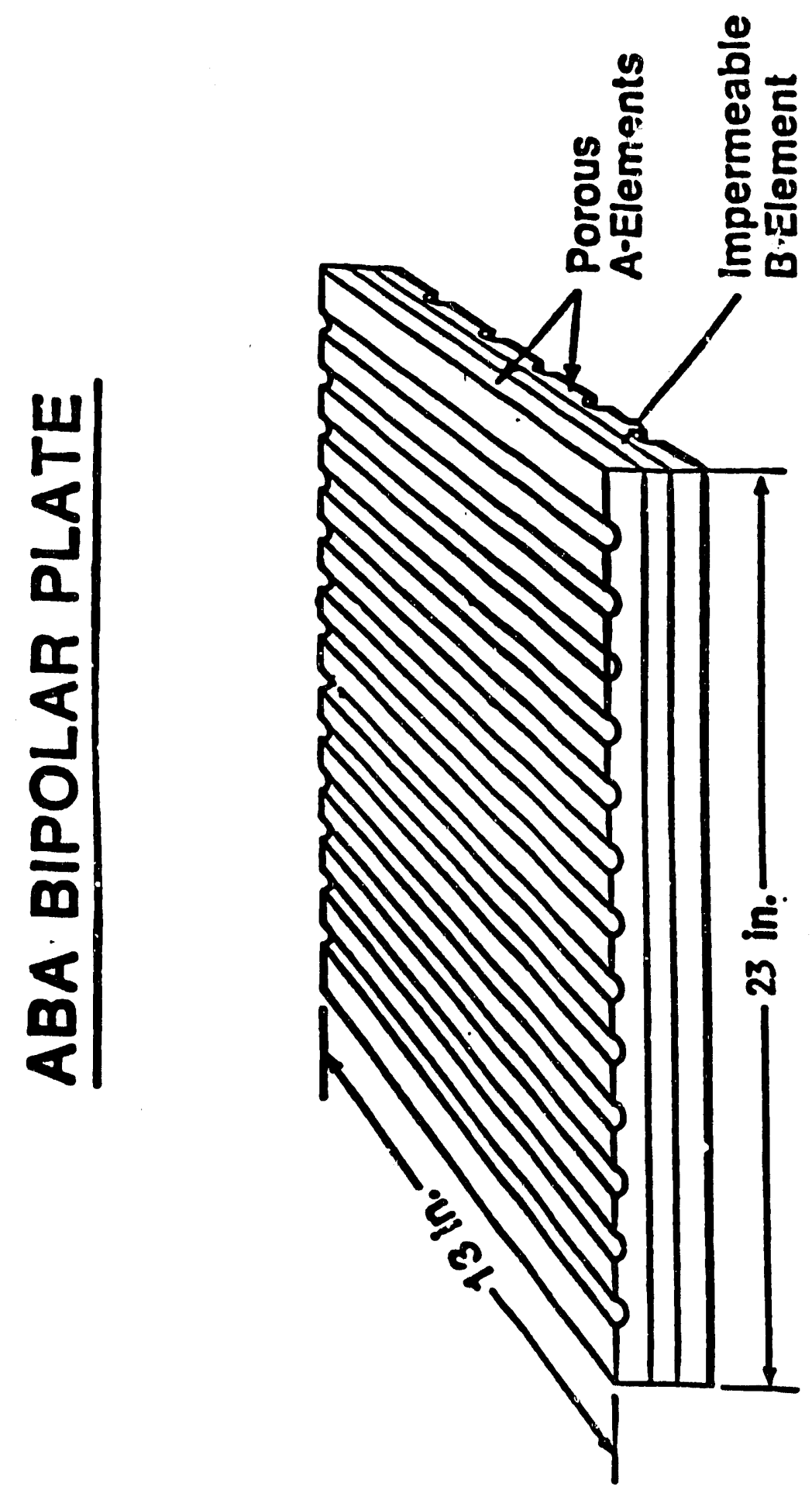

$\underset{1}{0}$

อ్ 


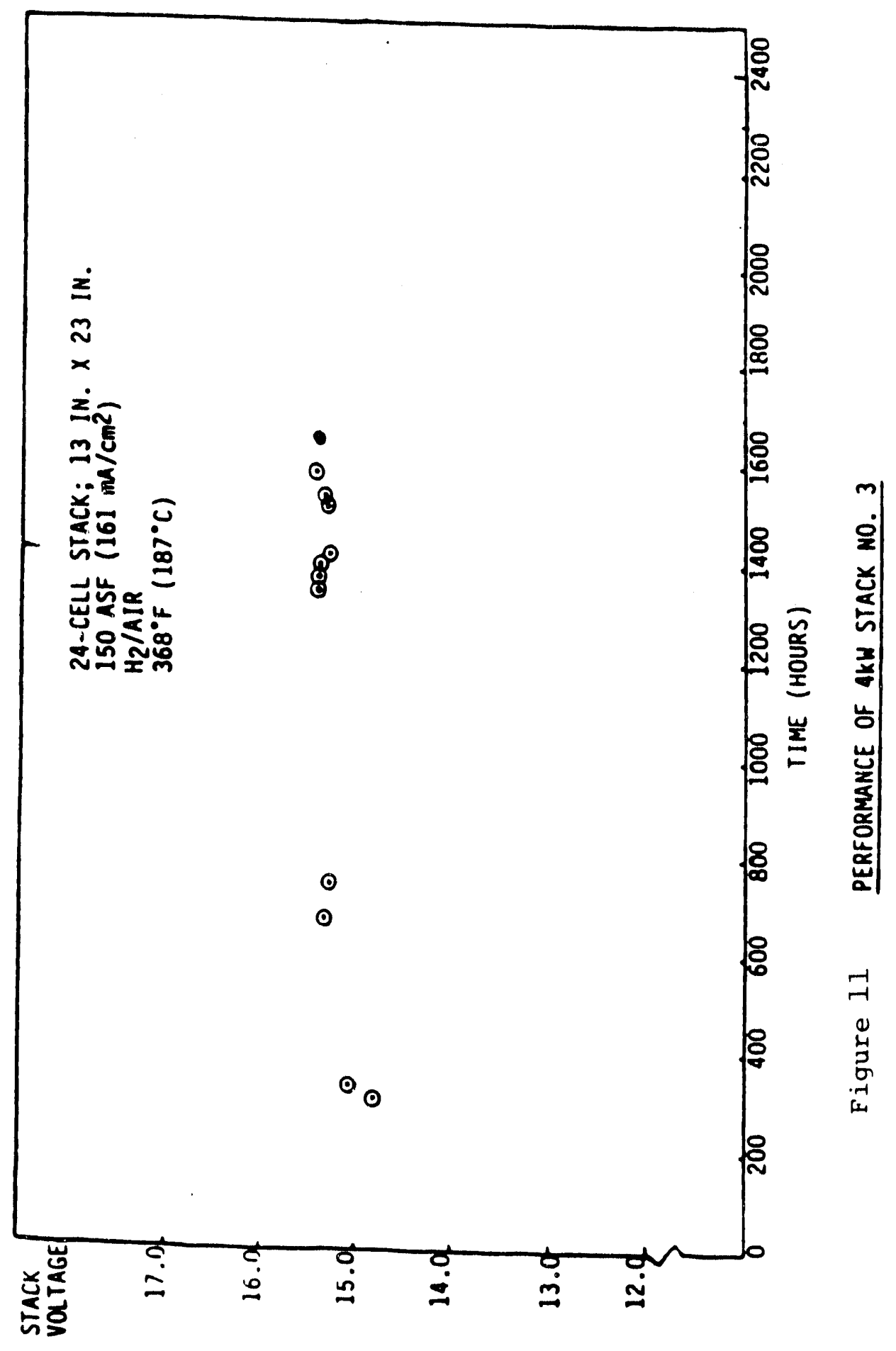

16 
The new technology features included in this stack were monitored for comparison with the corresponding standard features. Cells in the six-cell substack with alternative acid-transport layers outperformed those in other substacks, while the voltage loss at the bottom current collector, which was based on gold-clad wire, was well below $10 \mathrm{mV}$ at $161 \mathrm{~mA} / \mathrm{cm}^{2}$; this easily met the established goal (25mV maximum) and outperformed other configurations used in prior stacks at the same elapsed time, as shown in Figure 12. The temperature spread among the interior cells of the stack was only about $7{ }^{\circ} \mathrm{C}$ even though six-cell substacks (between cooling plates) were used instead of the previous five-cell sub-stacks.

This stack was shut down after 3200 hours for inspection of the PFA and PEEK type plates. The results were as follows:

- Stack performance was good throughout the test, as illustrated in Figure 13;

- The performance differences between cells with E-3 and E-2 cathode catalyst were minor;

- The performance of the six-cell substack with alternative acid-transport layers was far superior to that of the other substacks, as seen in Figure 10 .

- The PFA and PEEK type plates showed no tendency to delaminate, unlike prior stacks with polyethersulfonebonded plates; the latest plates looked like new, and even a strong force applied with a screwdriver could not delaminate the plates.

- The voltage loss at the gold-clad wire type current collector was less than $10 \mathrm{mV}$ at $161 \mathrm{~mA} / \mathrm{cm}^{2}$, clearly better than other configurations in prior stacks, as shown in Figure 14;

- The temperature spread among the cells in interior substacks was only about $7^{\circ} \mathrm{C}$, thus confirming the viability of six-cell substacks.

\section{$4 \mathrm{~kW}$ STACK NO. 4}

This stack was put on load in August 1987 for bench trials and evaluation of a Teflon-based graphite plate edge-sealing method (see Appendix 4).

At the beginning of November 1987, the average voltage of cells utilizing the E-3 bimetallic cathode catalyst (Substacks No. 2 and No. 3) was $0.637 \mathrm{~V}$ at full load $\left(161 \mathrm{~mA} / \mathrm{cm}^{2}\right)$ on hydrogen-air. 


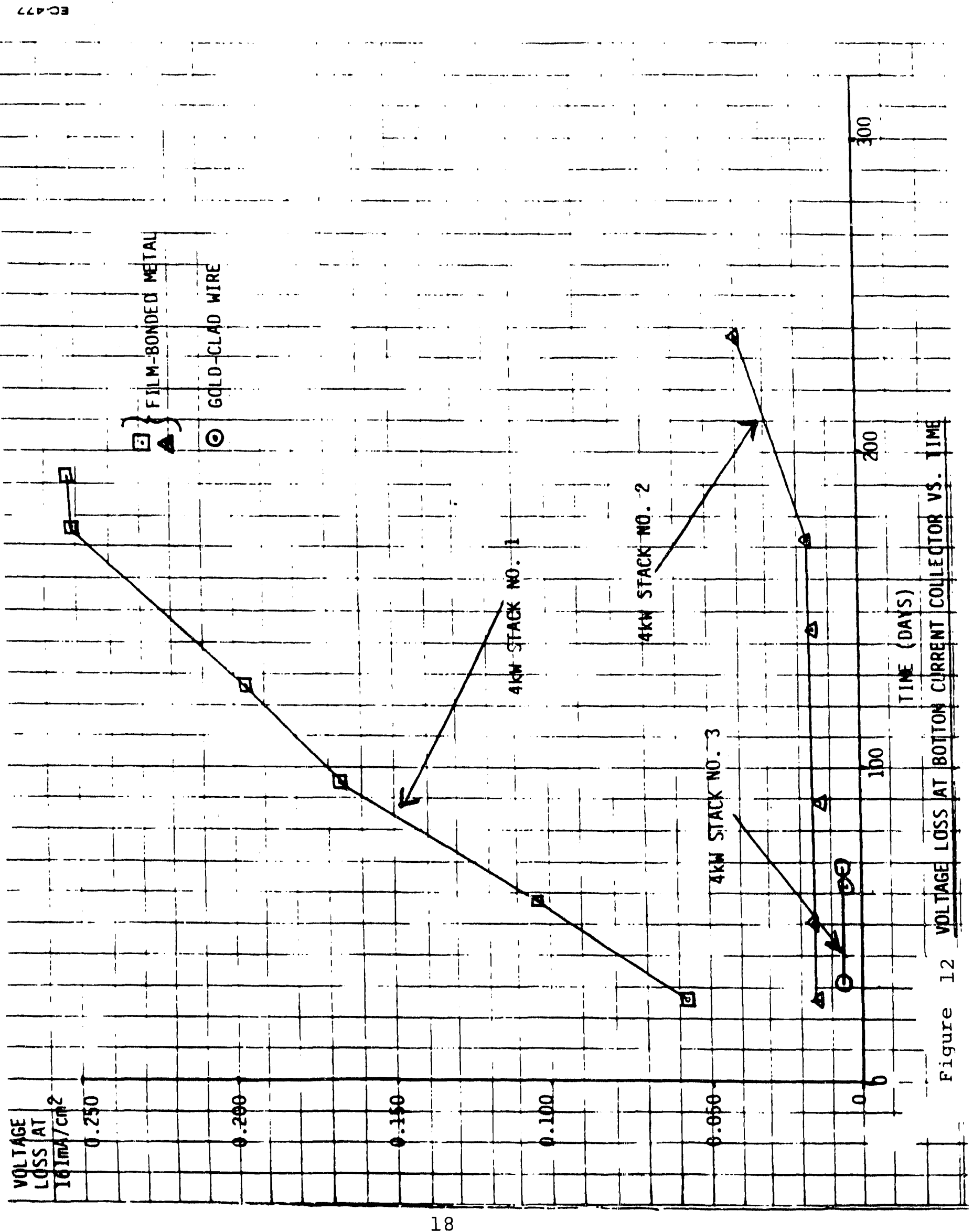




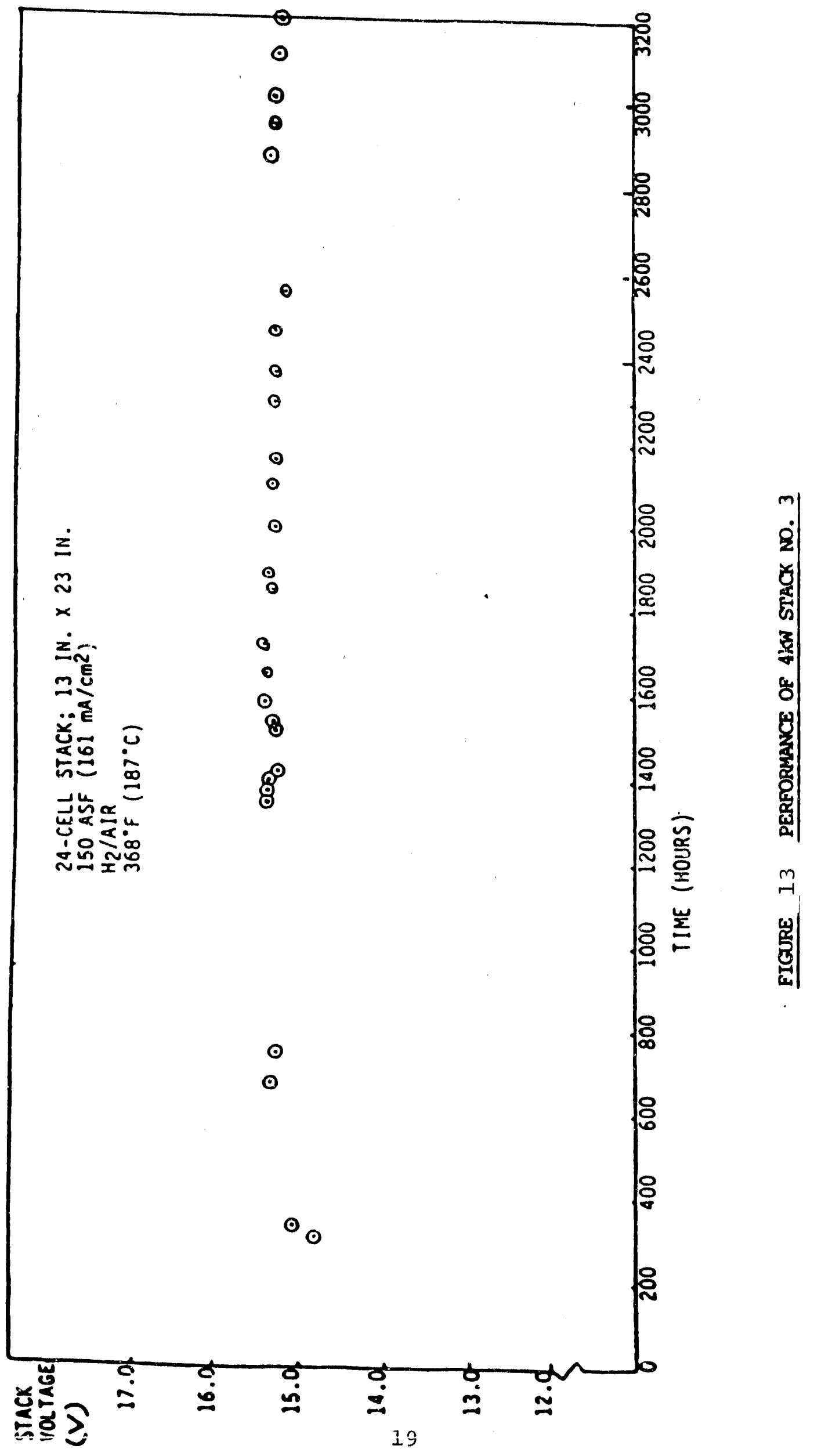




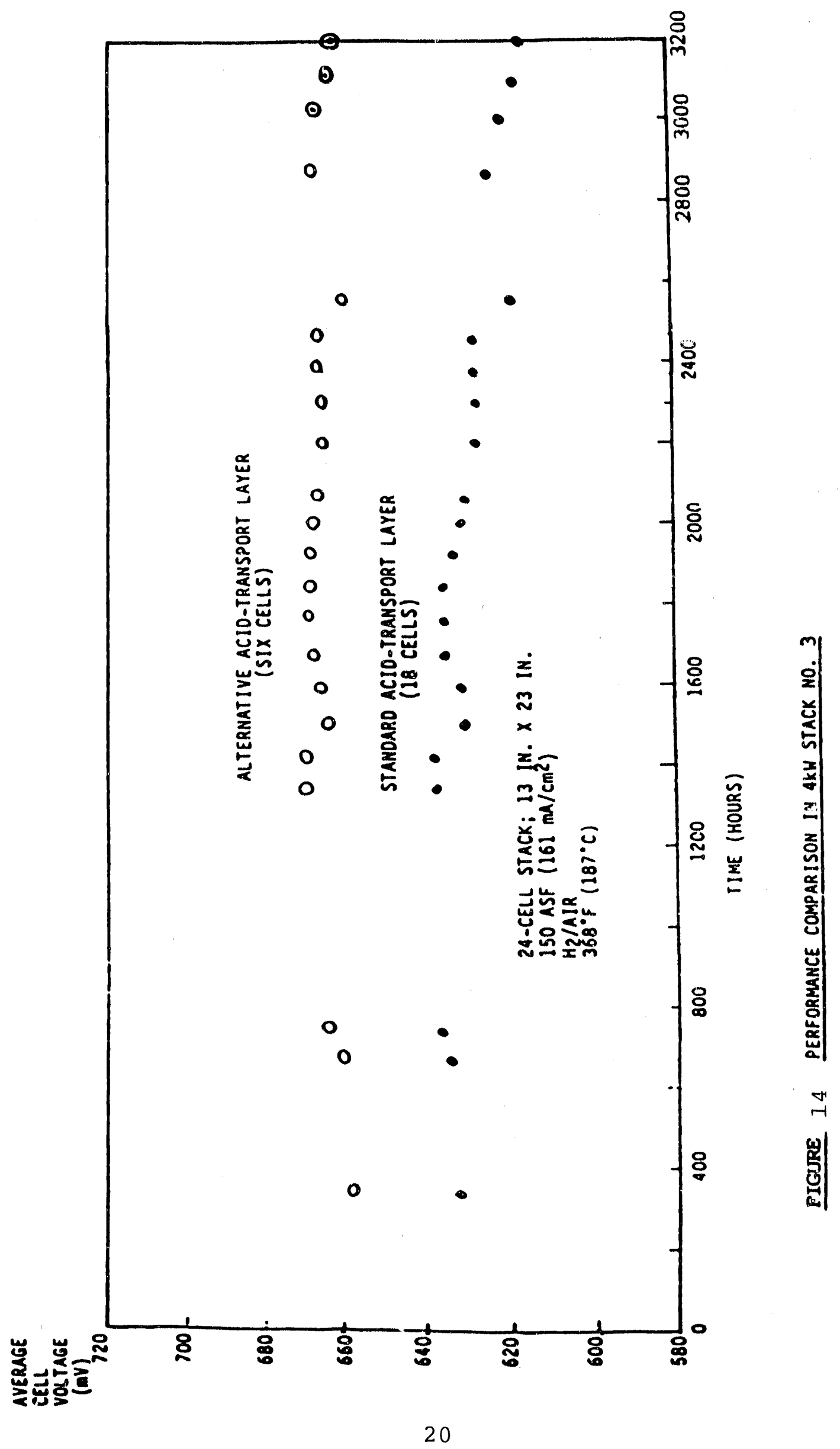


The cells with the E-7 bimetallic cathode catalyst (Substacks No. 1 and No. 4) sustained their performance advantage over the E-3 cells, with an average cell voltage of $0.651 \mathrm{~V}$, excluding Cell No. 3 (from the top), which showed substantial losses. These losses suggested that a section of the cell had been damaged due to acid deficiency, and acid was therefore added routinely to avert any repetition. Before this, acid had been added to the stack only twice over the first 2000 hours of operation because of the greater acid retention means built into the cells; however, the experience with Cell No. 3 showed that routine acid addition was still necessary.

Because of the seriously weakened condition of Cell No. 3 ( $<0.4 \mathrm{~V}$ at full load), the stack was shut down for inspection and replacement of this cell in November 1987 . Inspection confirmed that the scurce of the problem had been acid deficiency: there was a wedge-shaped burned area on the cathode and adjacent bipolar plate. The pattern of the burned area suggested that a section of the electrode wet-seal on the fuel inlet edge had dried out and had allowed hydrogen to penetrate the cathode. (The adoption of routine acid addition procedures after the start of decay in this cell avoided any further acid-starvation problems.)

Cell No. 3 was replaced along with Cell No. 4 and the damaged plate between them. The stack was reassembled and operated well thereafter. Pe:formance rose slowly and stabilized, and the average cell voltage at the end of January 1988 was $0.635 \mathrm{~V}$ at full load on hydrogen-air. The performance of the individual cells is shown in Figure 15; a plot showing the stack voltage history at full lcad over six months of operation is presented in Figure 16.

Just before this stack was shut down in March 1988 following a D.O.E. managerial decision, the average cell voltage had been $0.635 \mathrm{~V}$ at full load $\left(161 \mathrm{~mA} / \mathrm{cm}^{2}\right)$ on hydrogen-air. The distribution of performance at that time among the various cells is shown in Figure 17. Cells 17 and 20 showed abnormally low performance. This was probably due to greater than usual loses from a combination of the following: reactant gas crossover in adjacent bipolar plates and through the electrolyte matrix; and partial blockage of hydrogen flow paths in the anode grooves due to acid droplets. The performance history of the stack extended to the end of its 5000 hour test period is shown in Figure 18 .

$$
\text { B - FULL-SIZE STACKS }
$$

\section{System Considerations and Summary}

After initial testing with the methanol reformer, all subsequent testing was conducted on natural gas fuel. 


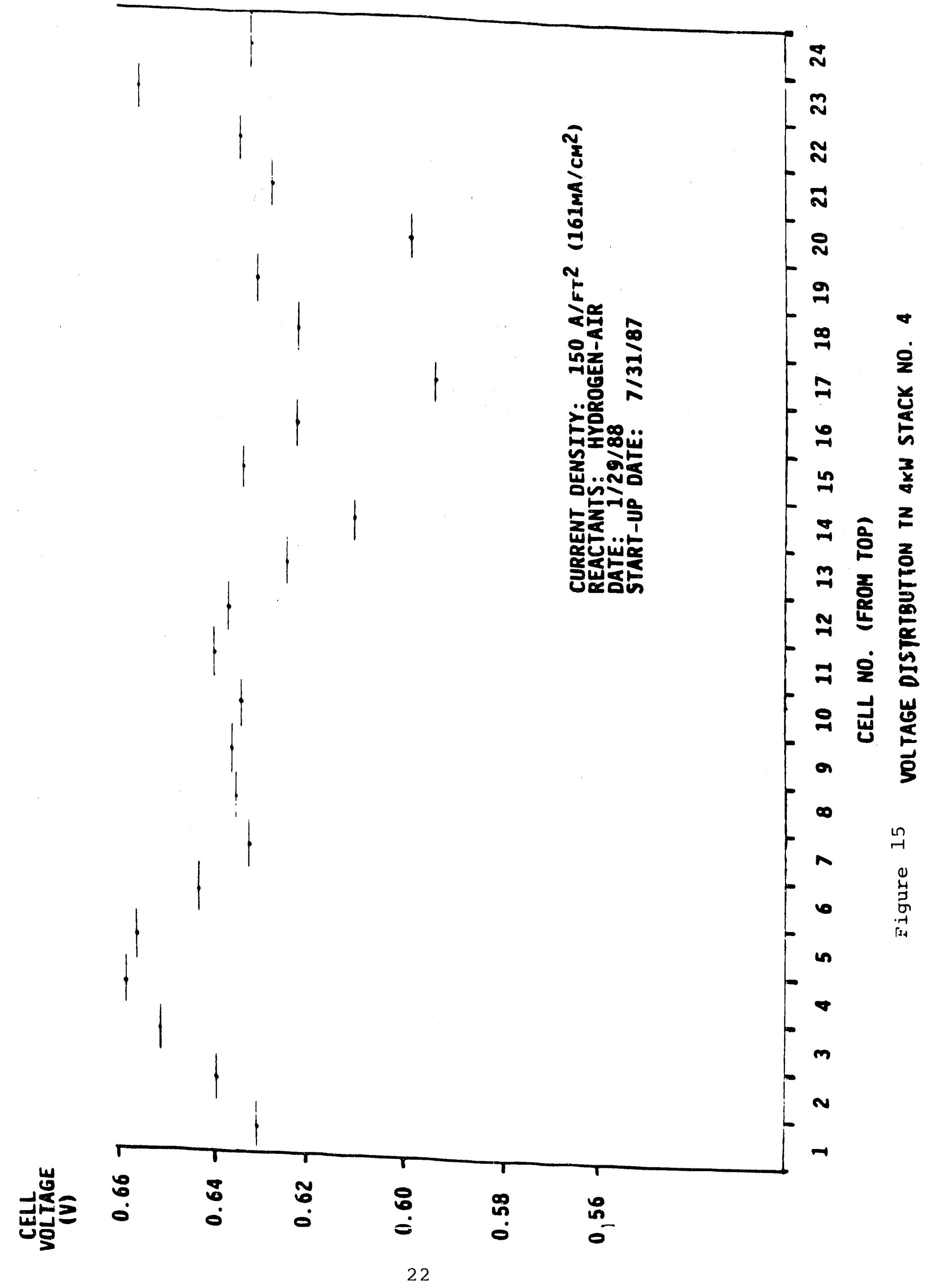




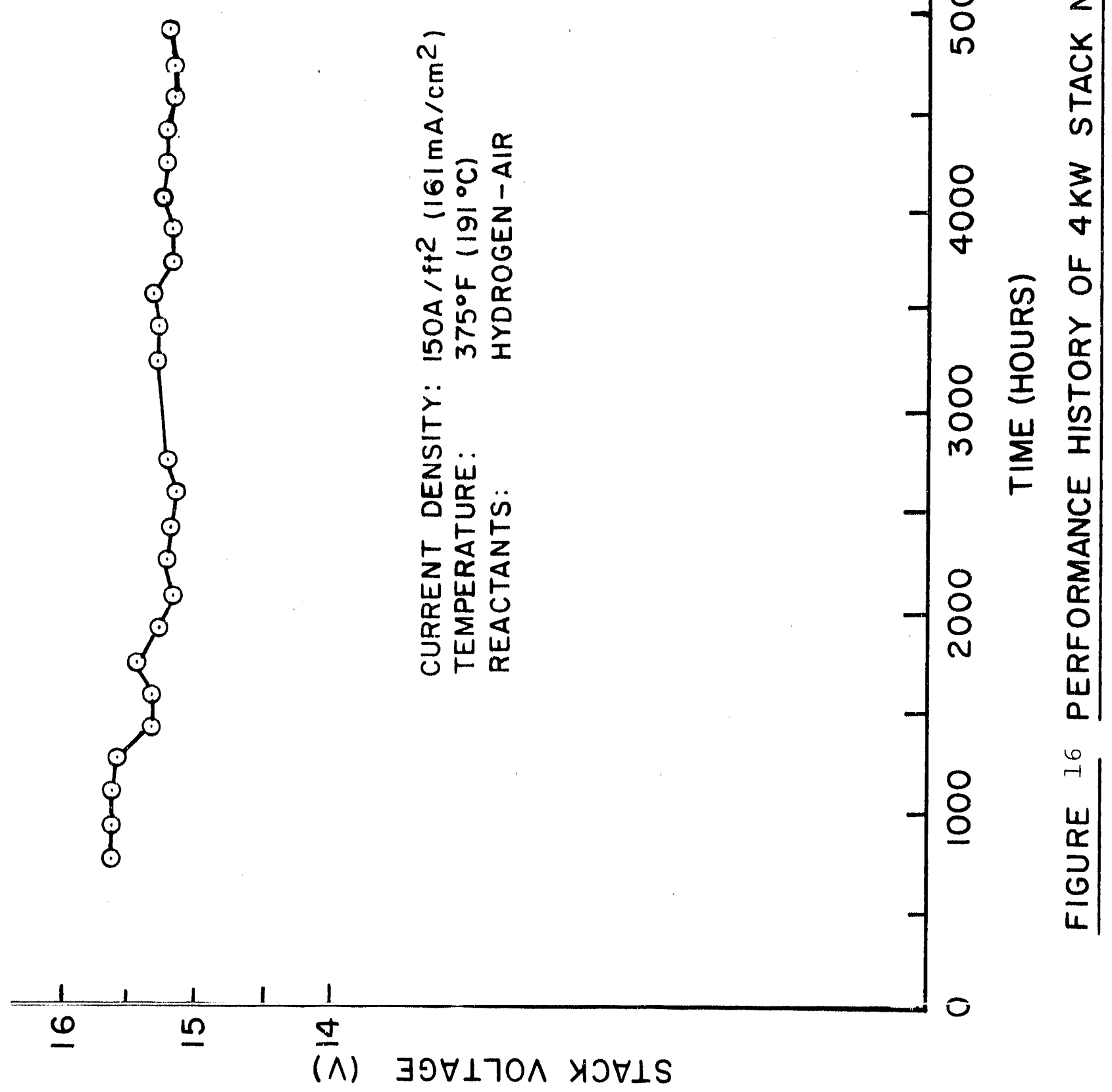




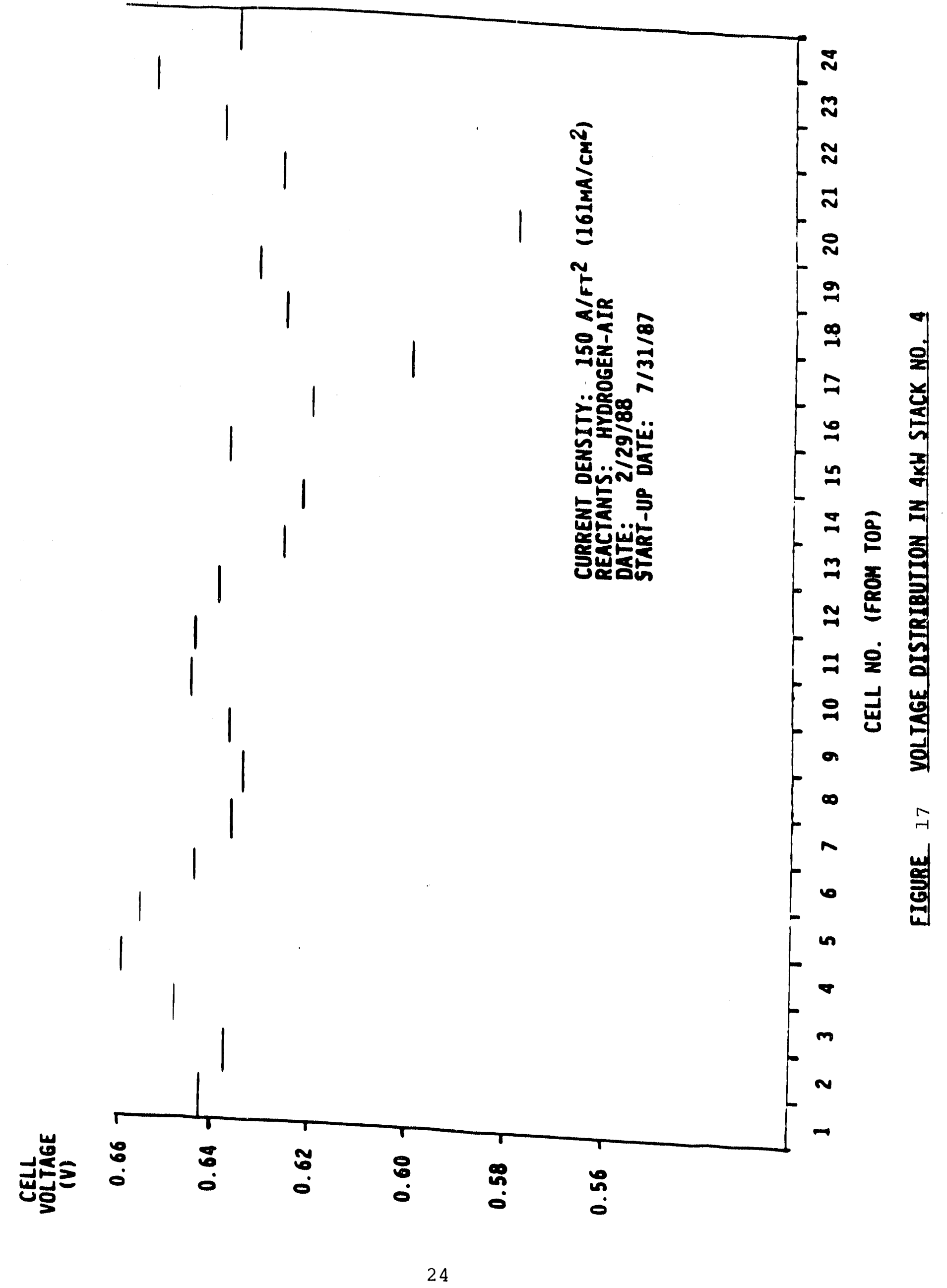




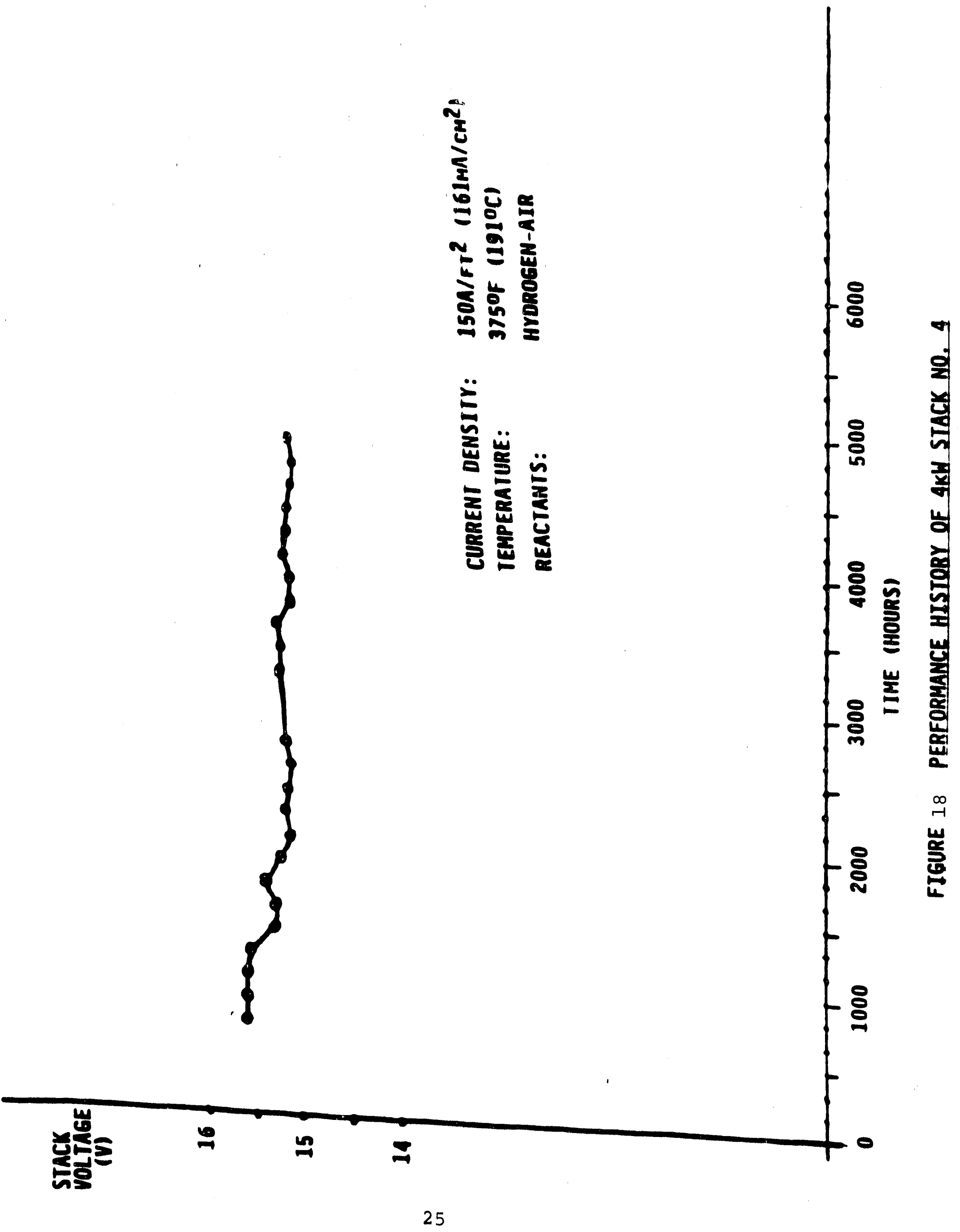


Initial integrated testing of the natural-gas/air system used the stack as received from the methanol-air system. The first integration of the stack and natural gas reformer took place in March 1988 and the stack was then reworked. The goal was to allow full-load operation, which could not previously take place because of damage to the bottom two substacks (this had occurred during the original startup phase with the methanol reformer due to inadequately tightened cooling tube end-connections). The rework. consisted of stack shutdown, disassembly, inspection, replacement of the bottom two substacks, and reassembly. Rework involving other potential problem areas was carried out as appropriate.

The preparations for stack rework included the fabrication of replacement electrodes (with electrolyte-matrix layers) and the selection and earmarking of bipolar plate and cooling plate spares. Since the prior standard carbon paper (the electrode substrate material) made by stackpole Carbon Co. (PC-206) was no longer available, two alternative carbon paper materials were tested for possible use in future electrodes (see Task IV). Toray paper and Great Lakes paper appeared to be promising substitutes; the Great Lakes paper was processed in the necessary size for the $25 \mathrm{~kW}$ stack.

The stack was reassembled in May 1988 and then recommissioned to prepare it for integration with the natural gas reformer. Meanwhile, that reformer had been tested and optimized, and was first integrated with the $25 \mathrm{~kW}$ stack in March of 1988. After this integration and during the stack rework, the fuel processing system was further improved, maintained and modified as appropriate. Integrated system testing began at the end of May 1988. The full-load performance goal was a minimum average cell voltage of $0.6 \mathrm{~V}$ per cell throughout the test program.

\section{$25 \mathrm{~kW}$ STACK NO. 1}

The stack components were mainly of the type that had been successfully used in the first two $4 \mathrm{~kW}$ stacks (above). Where appropriate in light of data obtained on the smaller stacks, design changes were carried out for the $25 \mathrm{~kW}$ stack. These involved an acid collection/drainage method to avoid corrosion at the bottom of the gas manifolds and a 0.0015 inch thick gold foil layer at the bottom current-collecting plate interface, also to avoid corrosion as well as the buildup of interfacial IR-loss. Figures 19, 20, 21, and 22 illustrate various features and aspects of the stack.

The cells (175 of them, 13 inches $\times 23$ inches) were stacked in May 1985 using cooling plates at five-cell intervals. After assembly of the stack hardware, a light compressive load was applied. This was followed by connecting the fuel, air, and coolant 1 ines to and from the stack. 


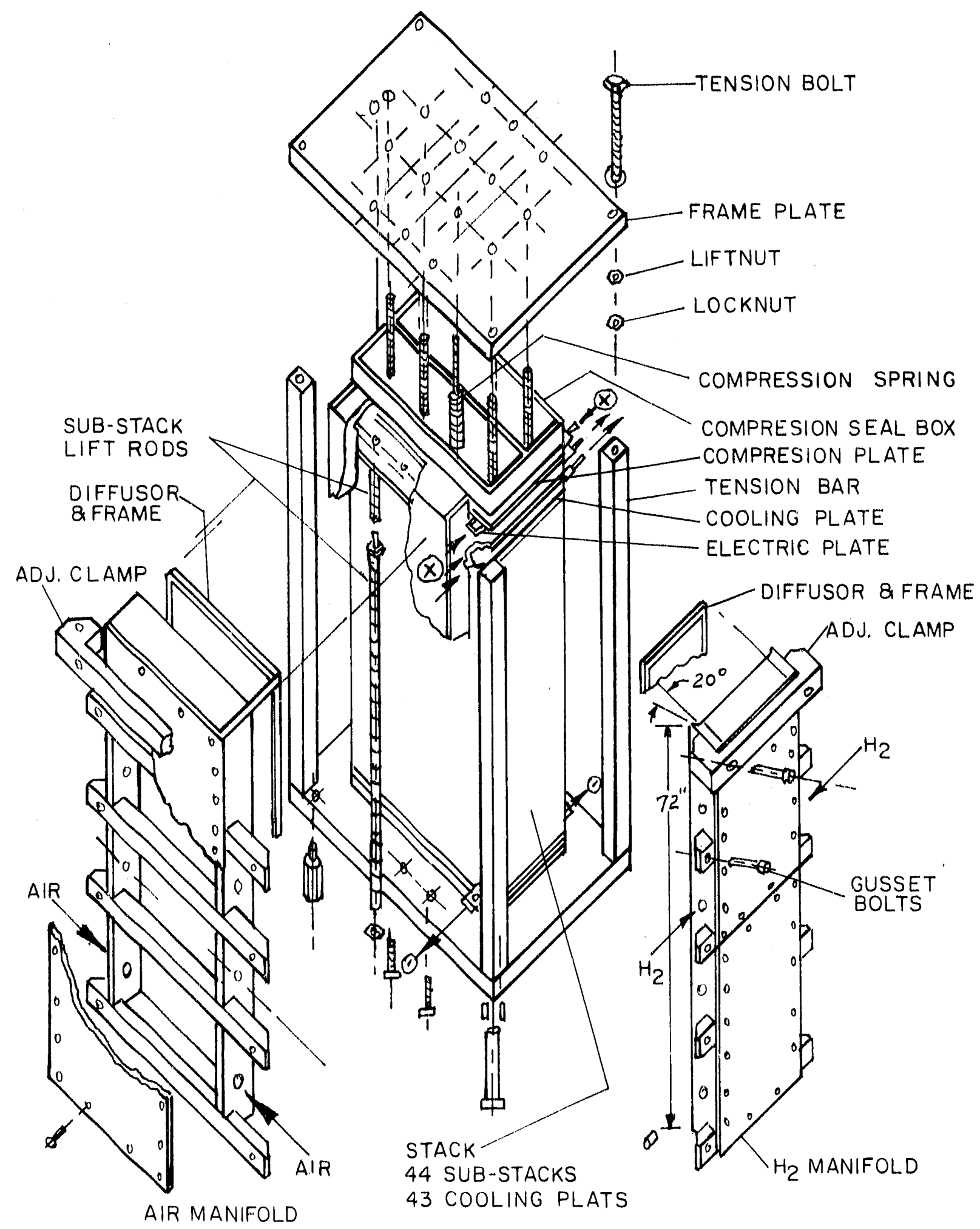

FIGURE $1925 \mathrm{KW}$ STACK NO.I 


\section{$=25 \mathrm{~kW}$ STACK N0.1}

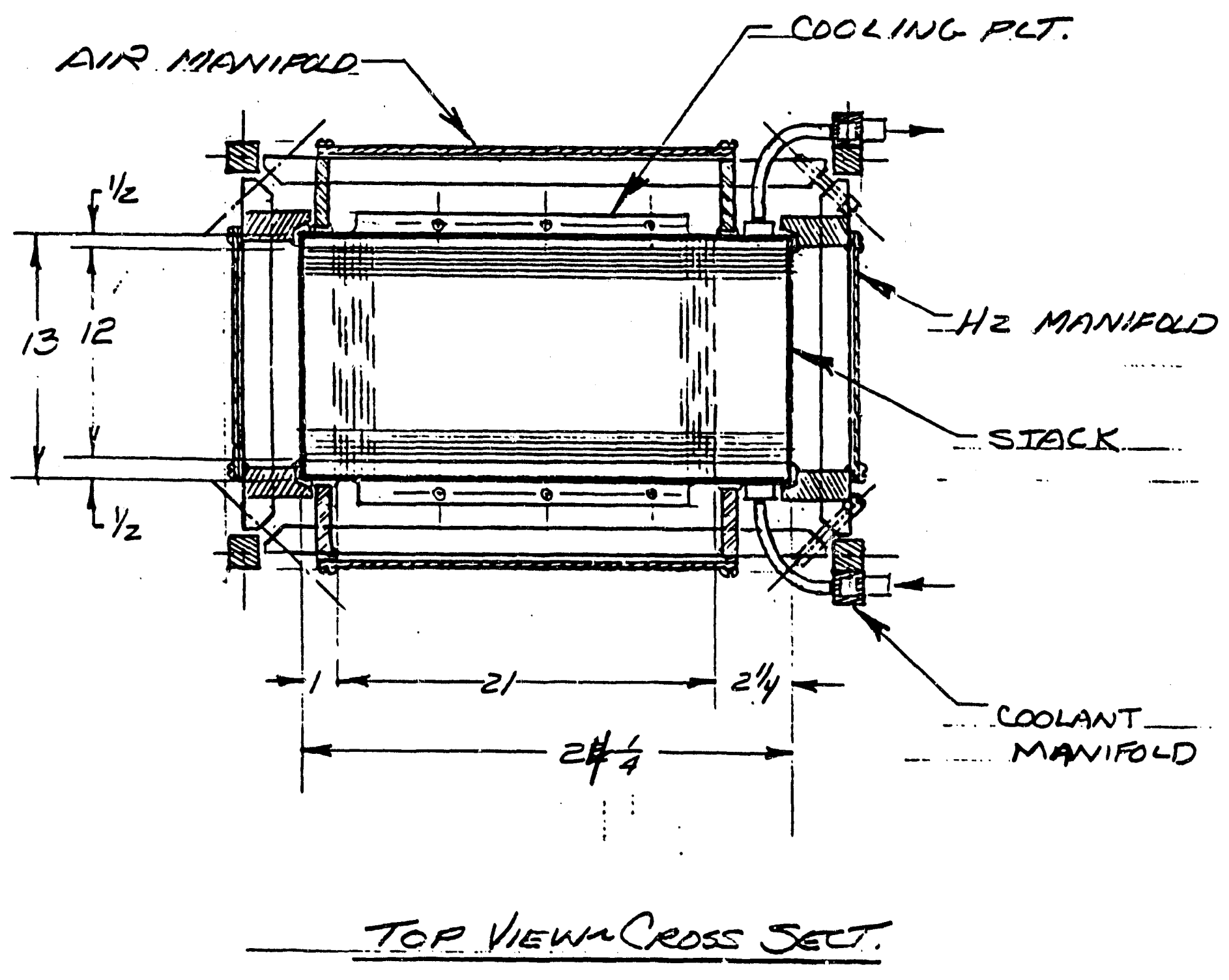

Piqure 20 


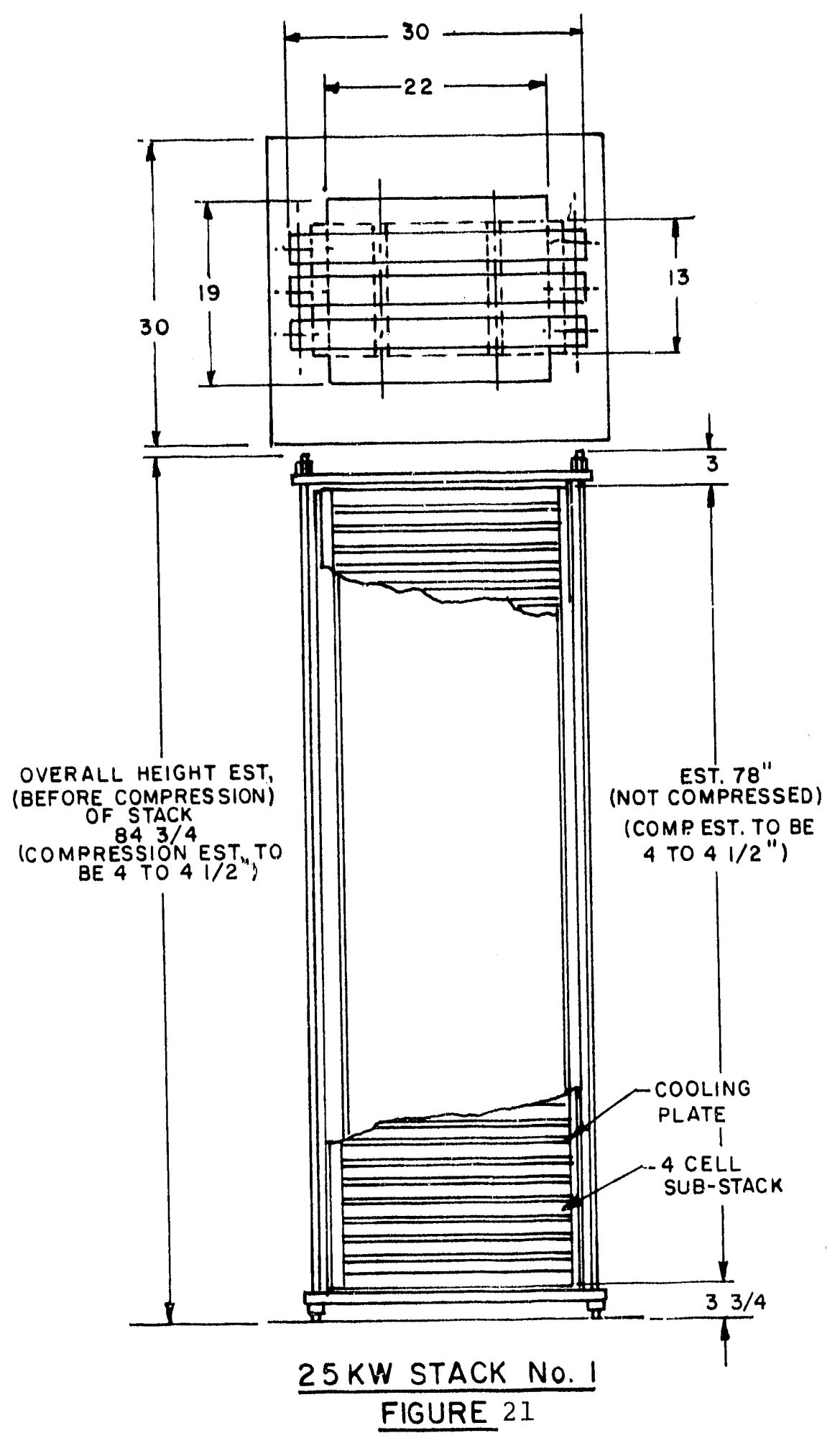




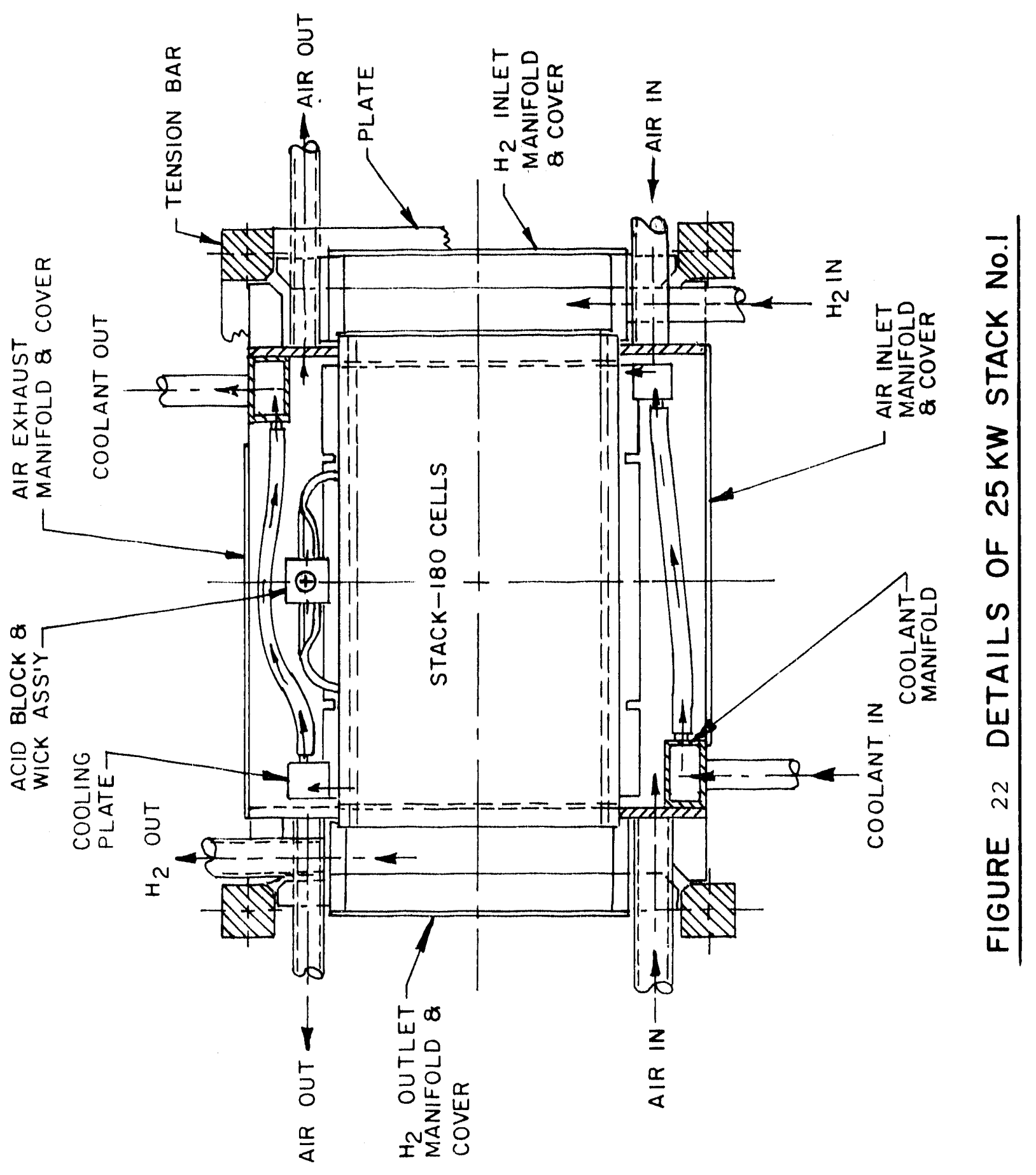


The acid-addition and compressive loading sequences were delayed into June 1985 by a series of unplanned stack heating system shut-downs (see below). Thereafter, the reactant gas manifolds were fully tightened. For the most part the stack remained in the hot-standby mode during June (about $120^{\circ} \mathrm{C}$; no load); however, interruptions due to external problems caused many temperature cycles (to and from room-temperature) during that month.

The stack was started on load in July 1985. The load was brought up gradually, as the cells appeared to be breaking-in very slowly. Acid was added (and taken up) in piecemeal fashion as the stack's load and temperature increased. Performance slowly improved during July and into August. Load was taken to $13 \mathrm{~kW}$ at a stack voltage of about $97 \mathrm{~V}$ with the temperature reaching $177^{\circ} \mathrm{C}$. Test results of using both hydrogen and reformate fuel, however, suggested that cell damage had occurred from the freeze-thaw cycles experienced before stack startup.

Due to problems with the methanol reformer system (see below), the integrated test of the stack did not resume until February of 1986 when the reformer was recommissioned. Testing continued into March; at mid-month and according to plan, the system was shut down to allow stack teardown, inspection of the bipolar plates, and rebuilding of the stack with fresh electrodes.

It was found that many of the PES-bonded plates had partially delaminated (as had happened in $4 \mathrm{~kW}$ Stacks No. 1 and No. 2 ). These plates were subsequently qualified for reuse through a combination of bench-tests and stack tests. Selected plates (from the group showing delamination) were subjected to gas permeability tests, which they passed. Also, others from this group were put into two six-cell sub-siacks, retrofitted into a rebuild of $4 \mathrm{~kW}$ stack No. 3 (see above), and tested briefly in this mode to confirm the stack-worthiness of plates from this group.

A full complement of ABA plates was qualified for a rebuild of $25 \mathrm{~kW}$ stack No. 1 in May 1986. Substack assembly began while all cooling plates were checked electrically under heat and pressure using a simulated assembly in the hot-press. Some cooling groove rework was required to establish good electrical contact in five of the plates. (This was attributed to a combination of out-of-spec groove depths and a slightly larger than nominal cooling tube outside diameter.)

The rebuild was completed in May 1986. The cooling/heating loop was then connected to bring the stack to hot-standby condition in preparation for testing. 
Testing of the gas manifolds showed a leak in a cover gasket of the fuel inlet manifold; this was corrected. When the system was restarted, two of the cooling tubes leaked late in the heat-up cycle. The leaks were traced to the reuse of cooling tubes and their compression fittings. The retightening of the fittings had apparently failed to provide enough contact between the ferrules and the prestrained cooling tubes, resulting in varying degrees of coolant leakage at the fuel inlet section of the stack.

It became apparent that reuse of Teflon cooling tube endconnections of the compression fitting type was risky. For this stack, the cooling tubes were therefore cut back and new Teflon ferrules installed on unstrained sections of the tube. In later assemblies, a spring-clamp type end-connection, found to be particularly reliable in the past, was utilized together with an adjacent metal-to-metal compression fitting, the latter to allow easy, damage-free disconnection and reconnection. (See Figures 23 and 24 ).

Rework of the cooling tube end-connections was completed in July 1986 and testing of these with coolant circulating at $175^{\circ} \mathrm{C}$ confirmed their leak-tightness. The stack was reassembled and placed on hot-standby $\left(135^{\circ} \mathrm{C}\right)$, with nitrogen flowing through the fuel side in the reverse direction to help drive off any coolant that might have been absorbed as a result of the earlier leak.

During August of $1986,175^{\circ} \mathrm{C}$ nitrogen was passed through the fuel side of the stack in the reverse direction for one week to further help drive off coolant absorbed as a result of the leak. The observed discharge of coolant vapor abated substantially during the week-long procedure. The fuel manifolds/gaskets were then reinstalled and the stack was started on load, once again using the methanol reformer to supply fuel.

The bottom five-cell substack showed signs of severe damage from the prior coolant leak; this substack was therefore electrically bypassed to allow testing to proceed. Load was reestablished at $90 \mathrm{~A}$ (one-third of rated load) before the end of August 1986. Operation was smooth except for a minor anode vent gas leak that became apparent when this stream was fed to the reformer burner; this was corrected by adjusting a manifold frame hold-down support structure at the top of the stack, and testing was resumed.

Integrated operation of the $25 \mathrm{~kW}$ stack in conjunction with the methanol reformer system continued during september and october 1986. The stack current was raised to 135A (half of rated load) during this period. After the first week the system was operated intermittently, and start-ups and shut-downs were performed uneventfully. 


\section{TEFLON COOLMLA TUBE END CONhLCTIONS}
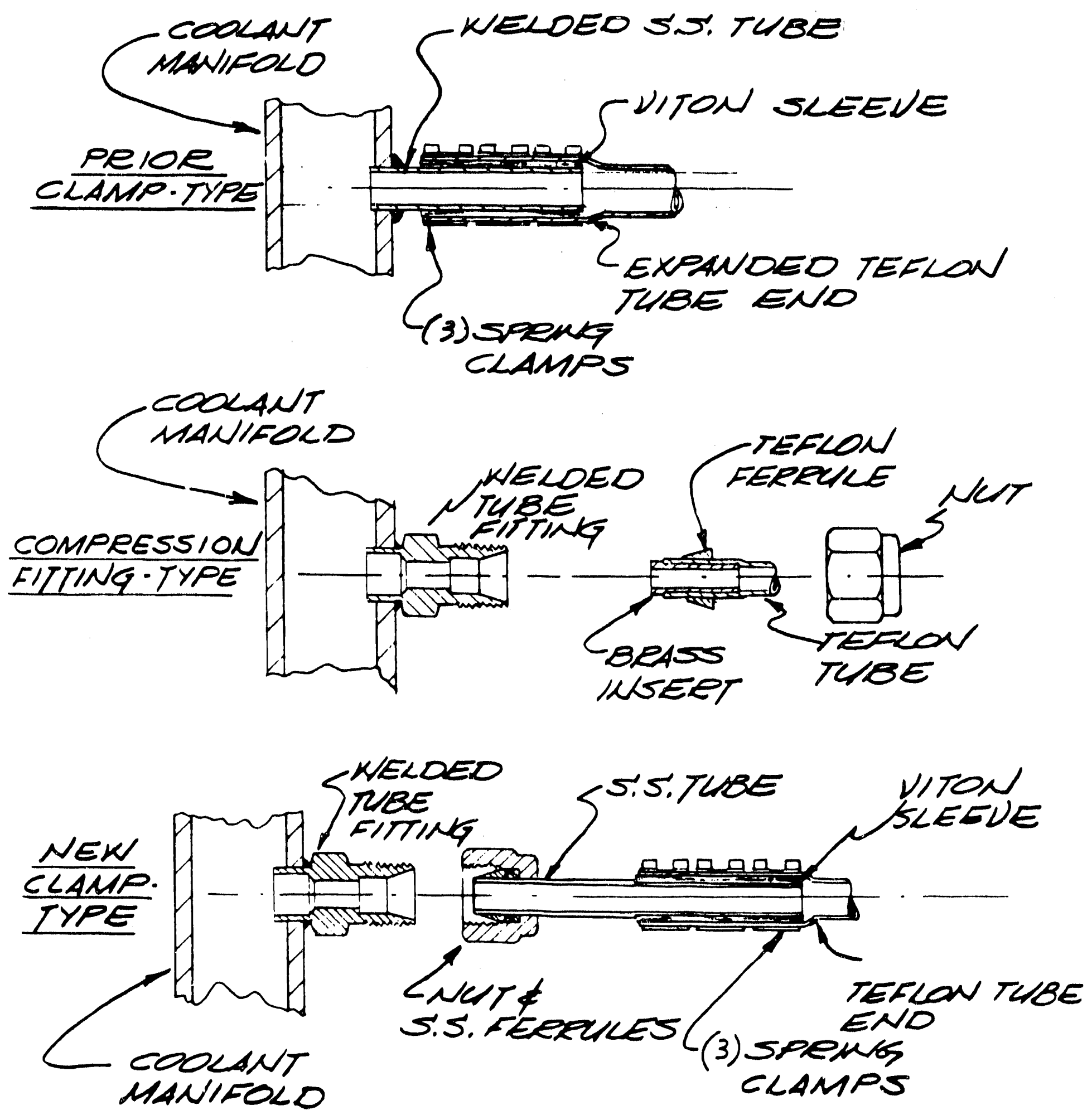

FI.JURE 23 
Integrated operation with the methanol reformer system continued during the early part of November 1986. Both the reformer and the overall system ran smoothly and trouble-free. Testing was suspended during the second week of the month to prepare for the installation of $25 \mathrm{~kW}$ Stack No. 2 .

\section{$25 \mathrm{~kW}$ STACK NO. 2}

Preparations for the advanced $25 \mathrm{~kW}$ stack (No. 2) started in May 1986. This stack had six cells per cooling plate instead of four and it used thinner bipolar plates than $25 \mathrm{~kW}$ stack No. 1 . All graphite plates were received in sanded condition, and their thickness was found to be uniform ( \pm 0.0025 inch). Film-bonding, sizing, and edge-sealing were carried out and the plates grooved by an outside vendor.

The 3/8-inch diameter cooling tubes used in this stack allowed one cooling tube per cooling plate (instead of two, as would have been required by pressure-drop considerations if 1/4inch diameter tubing had been used). The end-connection design for these tubes was bench tested and the first $3 / 8$-inch diameter tube array received in July; compression-versus-deflection was checked after the ABK plates had been grooved. (This tubing was particularly sturdy compared to the previous 1/4-inch diameter tubing; its O.D. was 0.425 inch and its wall thickness 0.025 inch, compared to 0.290 inch $0 . D$. and 0.020 -inch wall thickness, for its predecessor. It held up especially well, even with a lot of handling.

Catalyst for this stack was prepared in $500 \mathrm{~g}$ batches for electrode fabrication. In contrast to previous stacks, one of the coolant headers was shifted from the fuel inlet manifold to the fuel exit manifold, thereby minimizing interference among the cooling tube arrays. This also eased the task of connecting and disconnecting tubes to the headers, thus avoiding tube stress at the corrugations.

Two problem areas were encountered and corrected during this effort: cooling plate groove depth irregularities and inadequate bipolar and cooling plate edge-seals.

The cooling plates were completed during August 1986, but quality-control checking of groove depths at Engelhard showed that several plates had grooves that were too shallow, appparently due to undetected tool wear. These plates were subsequently reworked at the grooving vendor and accepted after re-tests.

Testing of the graphite plates for gas leakage showed that the edge seals were inadequate. This was attributed to the greater porosity and larger pores present in the PH graphite, as compared to the previous HLM material (for which the edge-seal 
method had been developed). After considering several rework alternatives (on both full-size plates and sub-scale samples), Engelhard adopted a procedure in which a fluoropolymer adhesive layer was applied to the existing edge-seal; this method was then carried out for all graphite plates, which were then leak-tested to confirm gas-tightness.

The electrodes were completed along with their electroytematrix layers. Acid-transport layers were also fabricated after the performance of the alternative configuration (see Appendix 5) had been confirmed in single-cells.

The stack metal hardware was completed in October 1986. Before that, minor rework of the gas manifolds was carried out at a vendor's site to improve the seal between the frame and cover of the manifold. The desirability of this rework became evident during the testing of $25 \mathrm{~kW}$ stack No. 1 . The hardware was checked out (alignment, etc.) in early November via a "dummy-build"; a wooden box was constructed to simulate the stack during this exercise. This dummy stack was then inserted into the $25 \mathrm{~kW}$ system test station to allow preparation of suitable plumbing connections.

Substack assembly was completed in early December 1986. All substacks were installed in the alignment fixture, and the overall assembly of the stack was completed by mid-month. Plumbing connections to the stack were fine-tuned, and coolant was circulated through the stack and system.

The cooling fluid was heated electrically to bring the stack to a hot-standby condition $\left(250^{\circ} \mathrm{F}\right.$, no load). (The new cooling tube end-connection design, confirmed in bench-testing, was used in this stack; see Figure 14.) The compressive loading sequence for the stack was then started. This sequence was interrupted, however, by an involuntary shut-off of the coolant circulation pump. The problem was traced to a clogged filter element; after this was corrected, the compressive loading sequence was resumed and completed. The gas manifolds were tightened, and the stack was then ready for operation on load.

It was placed on load in January 1987. Initial performance was satisfactory at $45 \mathrm{~A}\left(27 \mathrm{~mA} / \mathrm{cm}^{2}\right)$ and $140^{\circ} \mathrm{C}$ with a voltage of $113 \mathrm{~V}(0.675 \mathrm{~V} / \mathrm{ce} 11)$, despite a shunt current that was traced to a new packing in the acid-replenishment column; unexpectedly, this packing was found to have appreciable electronic conductance and it was therefore replaced by the packing that had been used previously.

Another problem was the warping of the acid column at higher temperatures; this caused some of the wicks to pull out of either the cells or the column. A new column was therefore fabricated 
and annealed at a temperature slightly above the stack operating temperature. This replacement column was installed and its warping was insignificant. Electrical load was reapplied and both the load and the temperature were slowly increased. At the end of January, the stack showed $113.5 \mathrm{~V}(0.68 \mathrm{~V} / \mathrm{cell})$ at $97 \mathrm{~A}\left(58 \mathrm{~mA} / \mathrm{cm}^{2}\right)$.

The stack remained on load into February 1987, with its performance showing steady improvement at $90 \AA$. Testing was interrupted by an electrolytic short across a gas manifold gasket from the stack to the manifold frame. This apparently resulted from an abnormal buildup of acid/water at the corresponding corners of two cells (the bottom cell and one midway up the stack) on the air exit side.

To protect against the consequences of another such occurrence, the manifold frames were removed, sent out for Teflon coating, and reinstalled at the end of the month.

Testing resumed in early March 1987. The load was increased from $90 \mathrm{~A}$ to $180 \mathrm{~A}\left(108 \mathrm{~mA} / \mathrm{cm}^{2}\right)$ over the course of the month. The stack voltage was $103 \mathrm{~V}$. Operation was temporarily switched back to hydrogen fuel because of a malfunction of the pump feeding methanol from the outdoor supply tanks to the system holding tank.

The pump was repaired and methanol-air system testing resumed at the beginning of April. Testing continued at $135 \mathrm{~A}$ and about 108V through April 1987.

The bottom two six-cell substacks, damaged during stack break-in, failed in mid-1987, so Engelhard decided to replace those components. Meanwhile, the stack was maintained in the hotstandby mode within the methanol-fueled system until late February 1988. It was then transferred to the natural gas processing test station and hooked up to its coolant loop. Fuel, air, and purgegas plumbing were connected, and the integrated system test started at the beginning of March 1988.

The integration sequence was carried out stepwise as follows:

(i) removal of stack from methanol system and placement in the natural gas system location;

(ii) connection of all plumbing hookups to the stack (fuel, air, conlant, and purge);

(iii) circulation of coolant through the stack to maintain the warm-standby condition;

(iv) operation of the natural gas reformer with the stack on hot-standby; 
(v) load-testing of the stack using bottled-hydrogen fuel while the natural gas reformer was fully operating;

(vi) open-loop integrated operation of the entire $25 \mathrm{~kW}$ natural gas system, including the stack (fueled by reformate) and the DC-AC power conditioner (which supplied AC power to the grid).

The stack ran at roughly half load (about 135A) while the power conditioner put out $12.5 \mathrm{~kW}$ AC. Further increases in stack load were deferred pending the rework.

Following the first phase of open-loop integrated system operation, the stack was disassembled for component inspection and rework. Inspection revealed that the graphite plate edge seals used in the original construction had developed cleavages in some regions of most plates (possibly occurring for the most part during the disassembly process); these seals were stripped off and the advanced Teflon-based edge-seals applied.

The rework was completed in May 1988, primarily having involved the application of the Teflon-based edge-seals to the graphite plates and the cleaning and quality-control testing of the cooling tubes.

All substacks were reassembled using the reworked components and fresh electrode/electrolyte-matrix packages that had been prepared for this purpose. The stack was reassembled and, after all the preliminary preparation and checkout procedures, it was placed on load in May 1988.

It was tested at $90 \mathrm{~A}$ on hydrogen fuel before the end of May, with all cells carefully examined for uniformity of voltage and temperature. They were all performing satisfactorily.

Testing of the reworked $25 \mathrm{~kW}$ stack on steam-reformed natural gas proceeded successfully into June 1988 as the load was raised to the maximum. The power generated was $24.3 \mathrm{~kW}$ at $147 \mathrm{~mA} / \mathrm{cm}^{2}$ and at an average cell voltage of $0.613 \mathrm{~V}$. Initially the current was held down by excessive minimum resistance in a resistive load bank which had been used temporarily in place of the power conditioner. The latter had a series of blown fuses (apparently incurred during an improper startup sequence) which were not immediately replaceable. The voltage-versus-current curve and the powerversus-current curve of the stack during open-loop operation on steam-reformed natural gas are shown in Figure 25 .

Before blowing its fuses, the power conditioner had performed at or above expectation at lower loads. At an input power of $7 \mathrm{~kW}$, it delivered $A C$ power to the house grid at $87 \%$ efficiency. During 


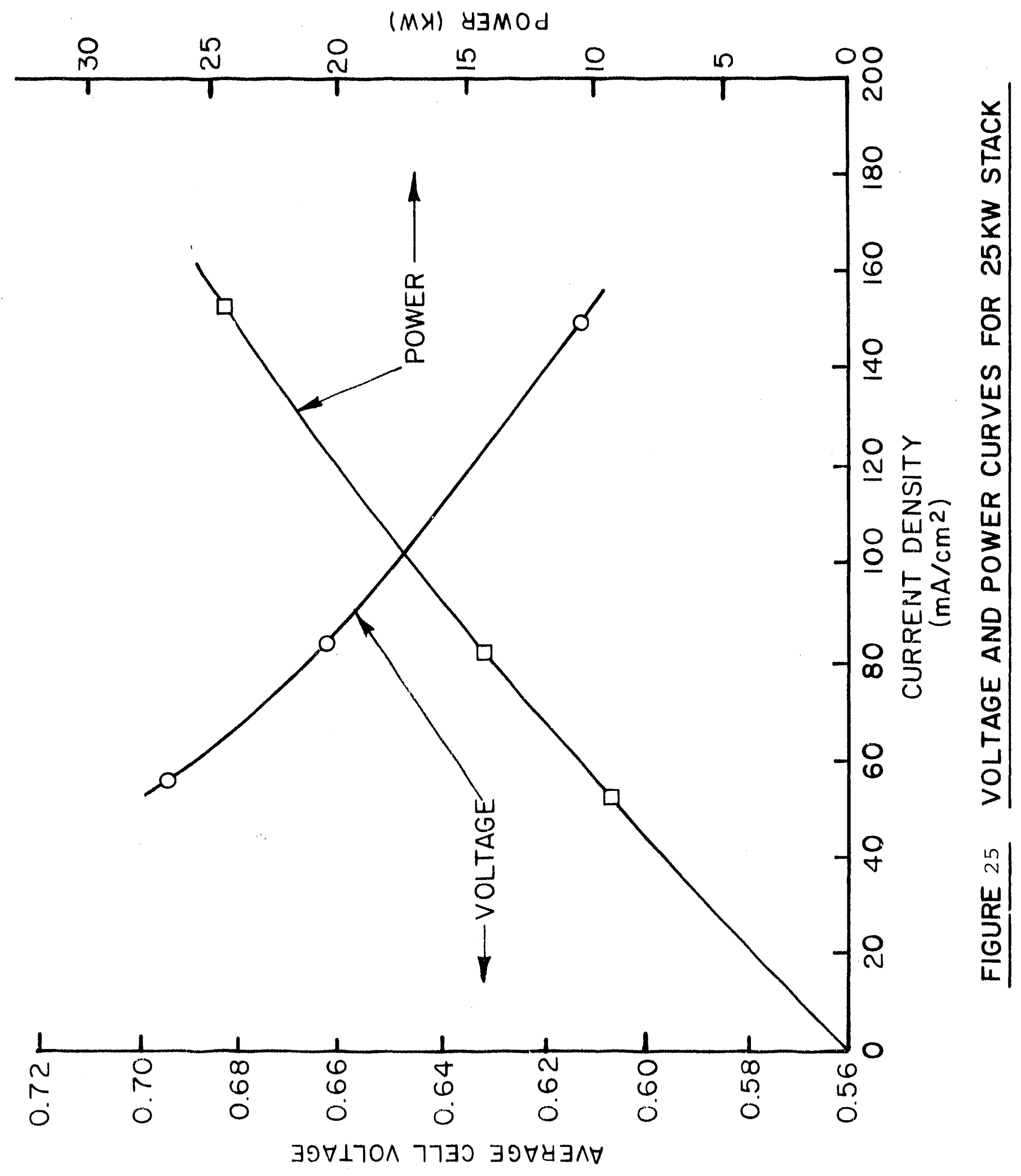


later tests at high loads, the efficiency virtually reached the specified value of $95 \%$.

Integrated system testing was interrupted in late June 1988 due to of a malfunction in the acid replenishment column. A plug in a spare hole became loose without being detected, thereby allowing acid to spill to the bottom of the air exit manifold and into the cells at the bottom of the stack. These cells became seriously clogged with acid and attempts to blow them out were unsuccessful. The bottom substack was therefore shorted out and isolated from the reactants. Testing was then resumed.

The integrated system ran in the open-loop mode until the last week in July 1988; performance in general remained good. Two cell pairs, one in substack No. 6 and one in substack No. 27 (top substack), showed weakness, indicating likely flaws in the intervening bipolar plates. These substacks were bypassed to avoid their interference with the test program. The average cell voltage during system testing is shown in Figure 26. Temperature distribution throughout the stack was also monitored during the test program. Figure 27 illustrates temperature variations as a function of load.

Closed-loop operation (complete integration including anode vent gas from the stack being returned to the reformer burner) was approached during the last week of July 1988 and achieved in August 1988. The initial phase of this task involved simulating anode vent gas by throttling a portion of the reformate from the shift converter exit to the reformer burner, so as to partially displace the natural gas that had been delivered to the burner in the open-loop mode. This resulted in a burner feed gas with a hydrogen concentration in excess of $40 \%$, greater than typical concentrations in anode vent gas. There were no signs of flashback.

In all, the test program lasted 10 weeks, 260 hours of which were on load, 125 hours at full load, 9 hours in the closed-1oop mode. 'ihe initial performance was 0.605 to 0.610 volt per cell on average at full load, as against a performance goal of 0.60 volt. The average cell voltage at the end of the test program was about 0.595 volt at full load. The estimated overall efficiency, including a $6 \%$ allowance for parasitic power, was $34.8 \%$.

The following was then accomplished through these tests:

- Acceptable performance from a stack that was rebuilt primarily from used components.

- Acceptable performance from the natural gas processing system designed and constructed by KTI and Engelhard. 


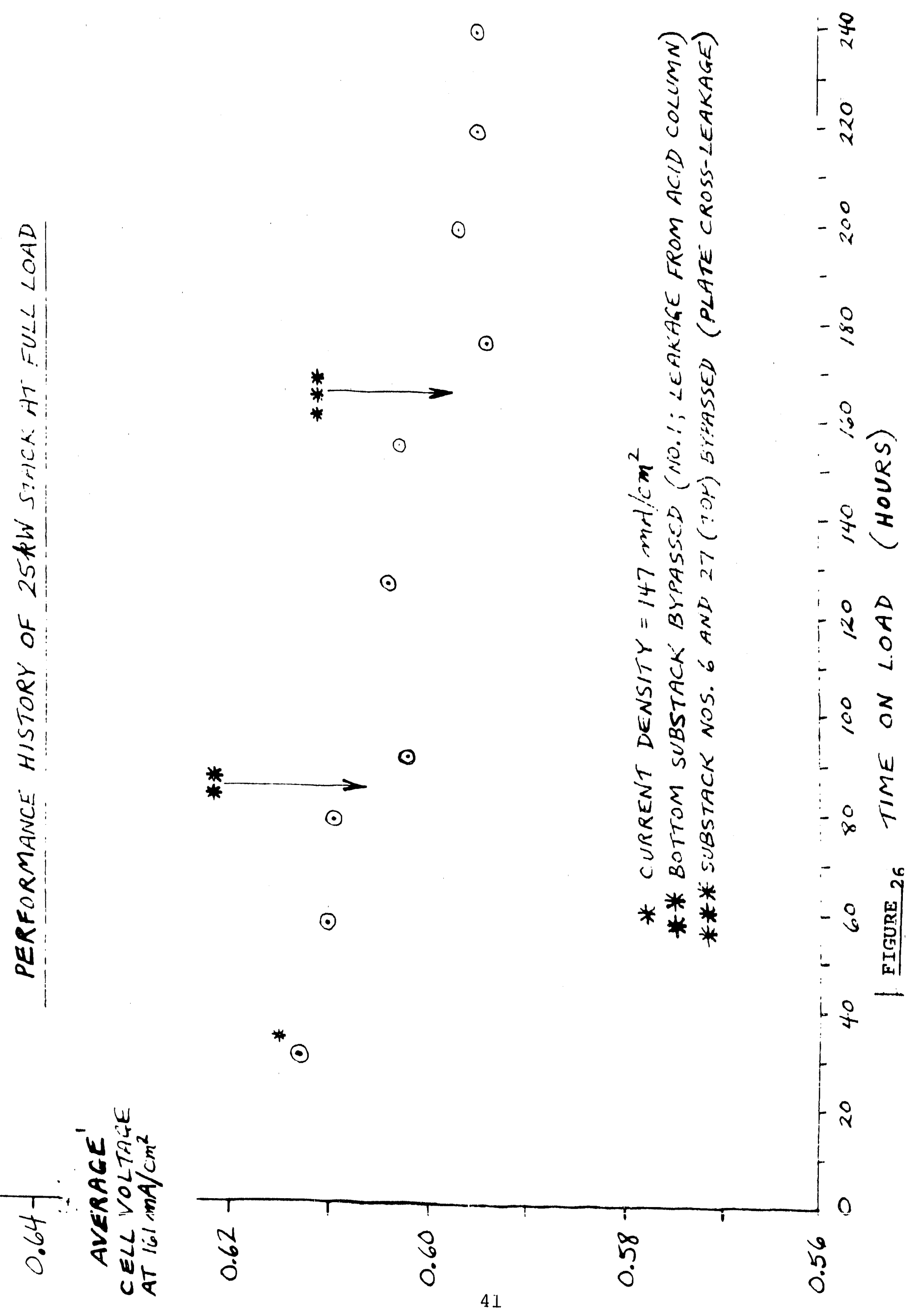




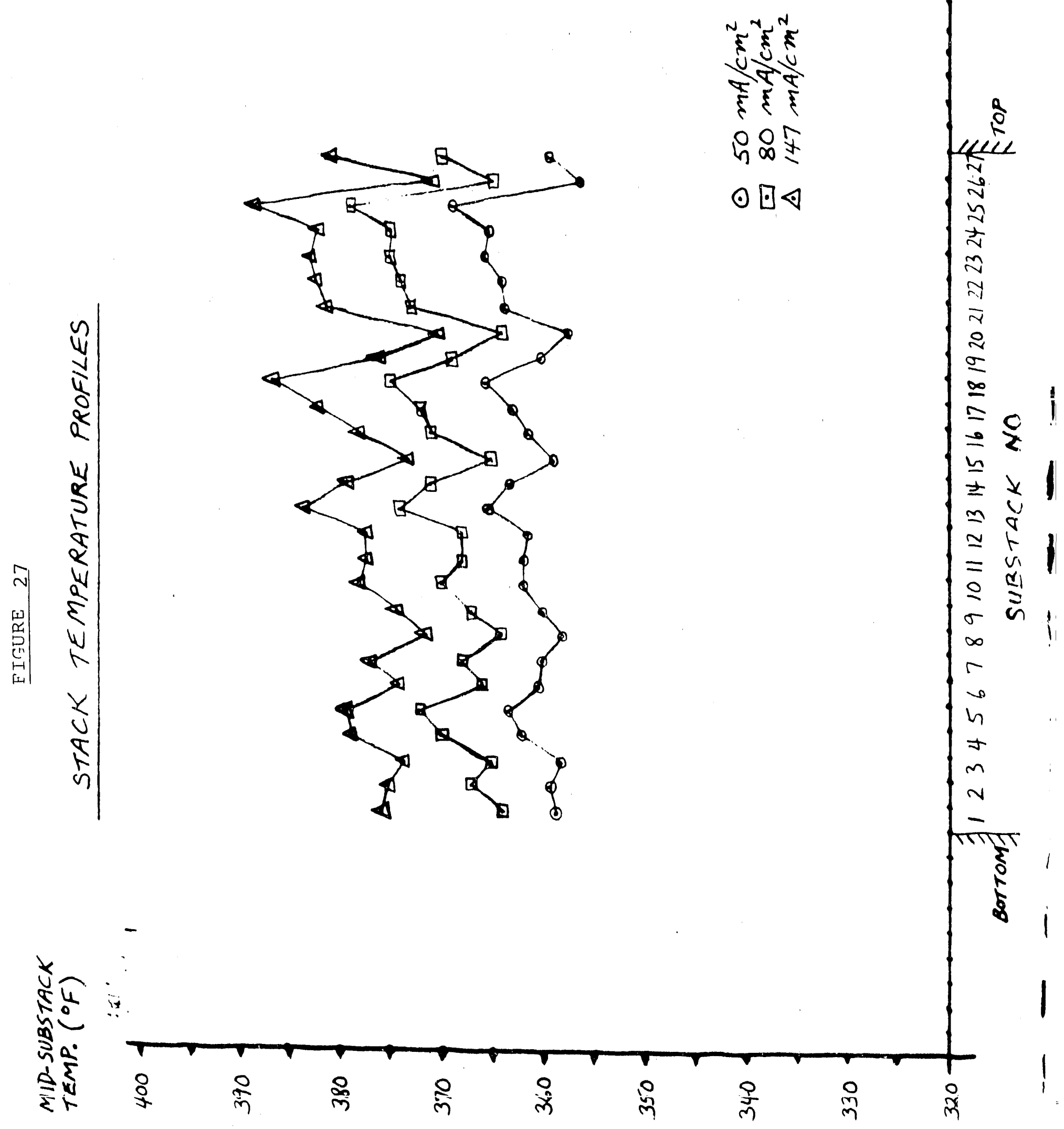


- Performance from the power conditioner in line with specifications (e.g., 958 efficiency at full load).

- Demonstration of closed-loop operation (complete integration of the system with anode vent gas being returned to the reformer burner) under conditions for which preliminary burner testing at Alzeta would have predicted flash-back.

- Effectiveness of control logic and control components in achieving smooth integrated system operation.

The following problems were addressed:

- Development of a leak in the acid-replenishment column, which led to irreversible damage to certain cells in the bottom substack; solution: (i) improved sealing technique for "spare" holes in column, and (ii) use of shorter, more frequent "on" times for the pump that circulates acid in response to signals from the timer.

- Development of cross-leakage in used bipolar plates in two separate substacks, as evidenced by voltage deterioration in the two adjacent cells; solution: (i) use of polyetheretherketone (PEEK) B-element resin as the $r_{j i} s$ separator phase in bipolar plates, in place of PFA Tuflon which was found to transport $\mathrm{H}_{2}$ about 30 times faster than PEEK, and (ii) more stringent quality control procedures for graphite plate elements (A-elements) to avoid large voids that could promote B-element permeation.

- Too much heat loss in the reformer and the auxiliary cciuponents, which tends to lower the system efficiency; solution: (i) improved thermal management through a compact layout of the system, and (ii) upgraded thermal insulation of the reformer, auxiliary units, and connecting piping.

- A burner prone to flashback; although the reformer burner resisted flasin-jack far better than expected, the tendency for flash-back mandates that alternatives be explored; solution: a non-porous radiative/ convective burner design is being pursued by KTI.

\section{SUBTASK III-2 LARGE FUEL PROCESSOR DEVELOPMENT}

\section{A. METHANOL FUEL PROCESSOR}

A $50 \mathrm{~kW}$ methanol processing sub-system was constructed for use as a hydrogen generator for the $25 \mathrm{~kW}$ stack. Testing and trouble- 
shooting of this unit started in May 1985.

The HVAC coil in the burner/heat-exchanger unit was found to remove more burner-generated heat than estimated. This cut down on the heat needed by the reformer. The coil was accordingly reworked to cut it by more than half, and adequate temperatures were subsequently achieved in the reformer.

A variable, resistive, electrical load bank was installed and custom rework was carried out. This involved additional circuitry for automatic switching in emergency or out-of-limits situations.

The reformer ran at flow rates equivalent to $32 \mathrm{~kW}$, and essentially complete methanol conversion was obtained ( $>99 \%$ based on condensate analysis). Also, outside analysis of an effluent gas sample showed satisfactory composition despite an unrecognized peak that showed up on the in-house chromatograph. The results are shown in Table $I$.

There was some loss of reformer performance in June 1985 when various system upsets occurred (see below). An apparent decline in reformer catalyst activity was traced to two out-of-limits conditions that, by design, should have triggered system shut-down (an over-temperature excursion and a methanol-water soak caused by reformer-burner flame-out).

The installation of control system hardware and wiring as well as the debugging of the software was completed during May 1985. (A software error, uncovered in June, allowed the aforementioned reformer catalyst soak to occur during unattended operation.)

The outdoor methanol storage tank became usable in June 1985 when a temporary permit allowing operation was issued by the Township of Union.

Numerous shut-downs were experienced during automatic operation of the $25 \mathrm{~kW}$ system in June and July of 1985. These were primarily related to the methanol pump that feeds the reformerburner and to the microprocessor. The pump was equipped with a heavy-duty motor, and the contacts of the computer were cleaned and sprayed with a protective coating. These steps were designed to improve the tolerance to the heat, humidity, and dust surrounding the system.

The methanol conversion efficiency fell during the early part of september 1985; this was attributed to an inadvertent overheating that occurred during a start-up. The reformer catalyst was taken out in late september and new catalyst reduced in-situ.

The reformer resumed operation in early october 1985. However, the catalyst was rapidly deactivating. The methanol in 
TABLE I

Composition Analysis of Reformate Gas Sample

May 1985
$50 \mathrm{~kW}$ Methanol Reformer
HP 5880 Chromatograph

Compound

$\mathrm{H}_{2}$

$\mathrm{CO}$

$\mathrm{CO}_{2}$

$\mathrm{CH}_{4}$
Gas Composition, Vol. $\frac{8}{8}$

$$
\begin{gathered}
77.8 \\
1.40 \\
21.0 \\
<0.05
\end{gathered}
$$


the fuel storage tanks was analyzed and found to contain almost $1000 \mathrm{ppm}$ of chlorinated hydrocarbons. The reformer catalyst was replaced after confirmation of contamination, reduced, and put back in operation during January 1986. The load was gradually increased and, at the equivalent of $22 \mathrm{~kW}$, methanol conversion was essentially complete ( $>99 \%)$.

The reformer continued to run at essentially complete methanol conversion during February 1985. The load range was extended to $30 \mathrm{~kW}$ equivalent and reformate fuel was supplied to the $25 \mathrm{~kW}$ stack at the February system restart. The reformer continued to work well until the planned shutdown in mid-March when it was subjected to minor upgrading and maintenance.

\section{B. NATURAL GAS FUEL PROCESSOR}

Preliminary testing of the natural gas processor (see Figures 28 and 29) began in November 1987. The Alzeta radiant burner (see Figure 30) was placed inside the reformer, and a flame-sensing scheme involving a flame-ionization detector cell inside a 3/4inch diameter protective pipe was evaluated. Flame-sensing was carried out successfully down to $25 \%$ of rated burner heat load during initial testing. During a subsequent extended test involving reduction and break-in of the reformer catalyst, however, the flame detection became less sensitive because of the higher temperatures as the reformer walls heated up. This caused a weaker signal from the flame-ionization cell: roughly 50\% of rated heat was needed to generate an adequate signal. The problem was alleviated by placing two thermocouples where they could respond quickly to a flame-out.

Preliminary reformer testing showed that the system temperature distribution needed upgrading, especially during start-up. In particular, the flue gas effluent from the reformer, which transfers heat to the incoming steam and to the combustion air, had too little sensible heat because of excessive heat losses. Therefore, the reformer and auxiliary units, along with the appropriate intermediate plumbing, were more heavily insulated.

Additional trouble-shooting within the fuel processor involved the igniter for the reformer burner. An additional access pipe was installed in the base of the burner to allow the igniter to be cooled by a small stream of air through the pipe, thereby preventing overheating and subsequent burn-out of the igniter.

The reformer started generating hydrogen in December 1987 up to the $25 \%$ load point. Higher throughputs were postponed because of problems in the fuel and steam flow-sensing systems. 
1

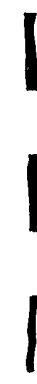

NATURAL GAS REFORMER SCHEMATIC

1
1
1
1
1

I

1

1

I

1

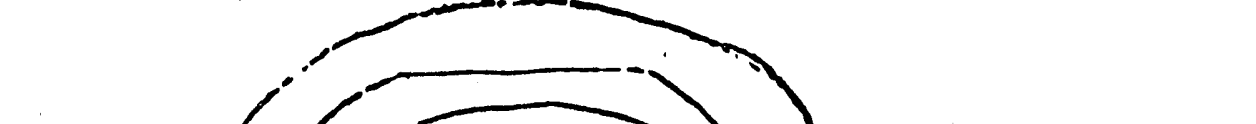

1

1
1
1
1
1
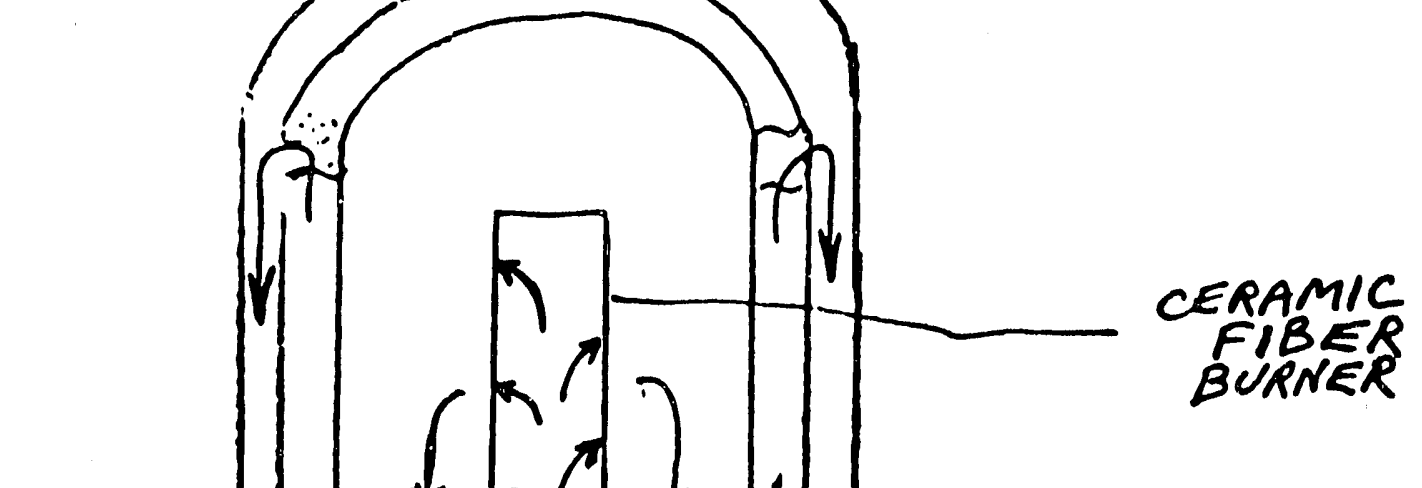

.

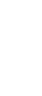
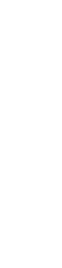

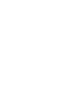

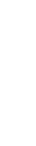




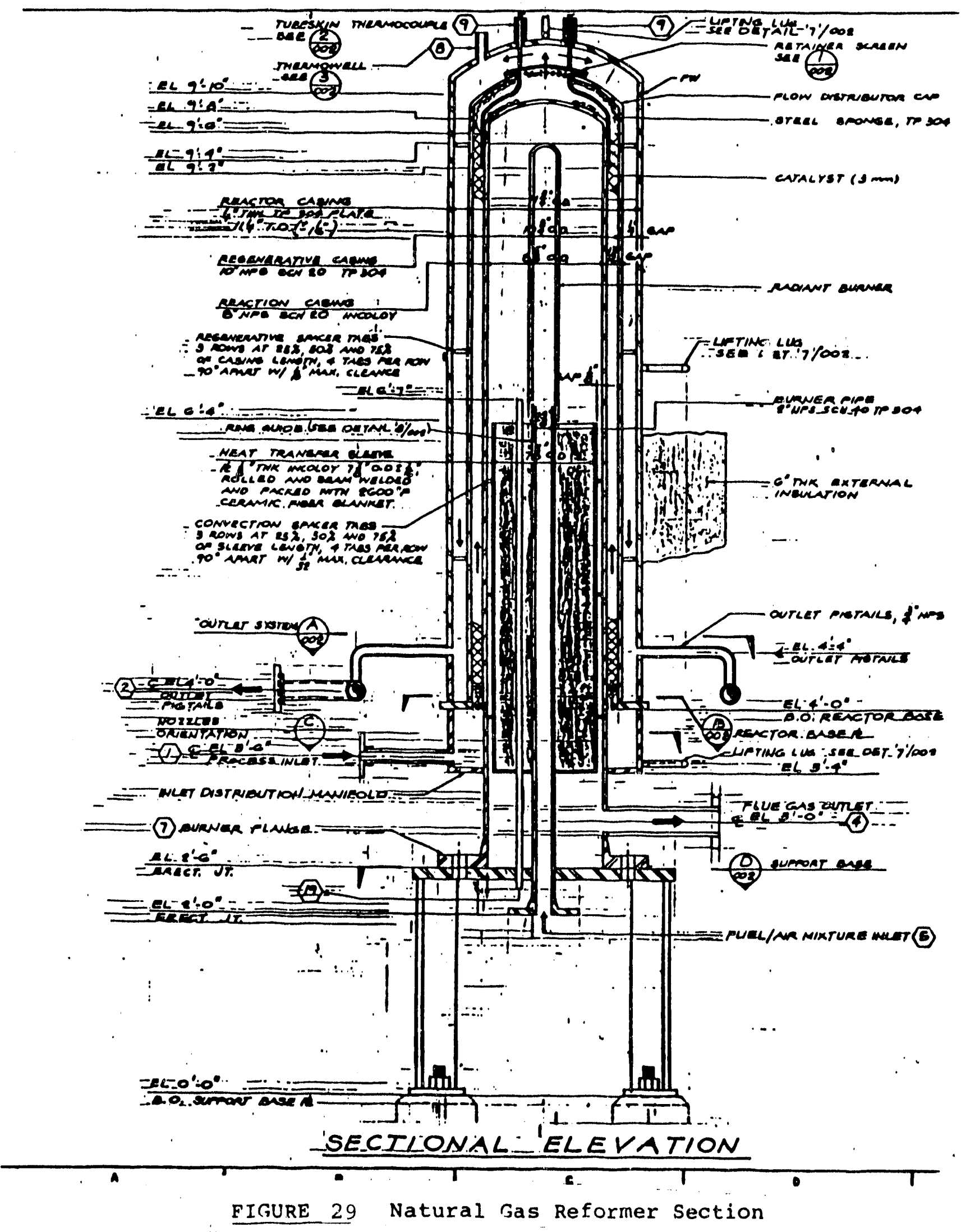




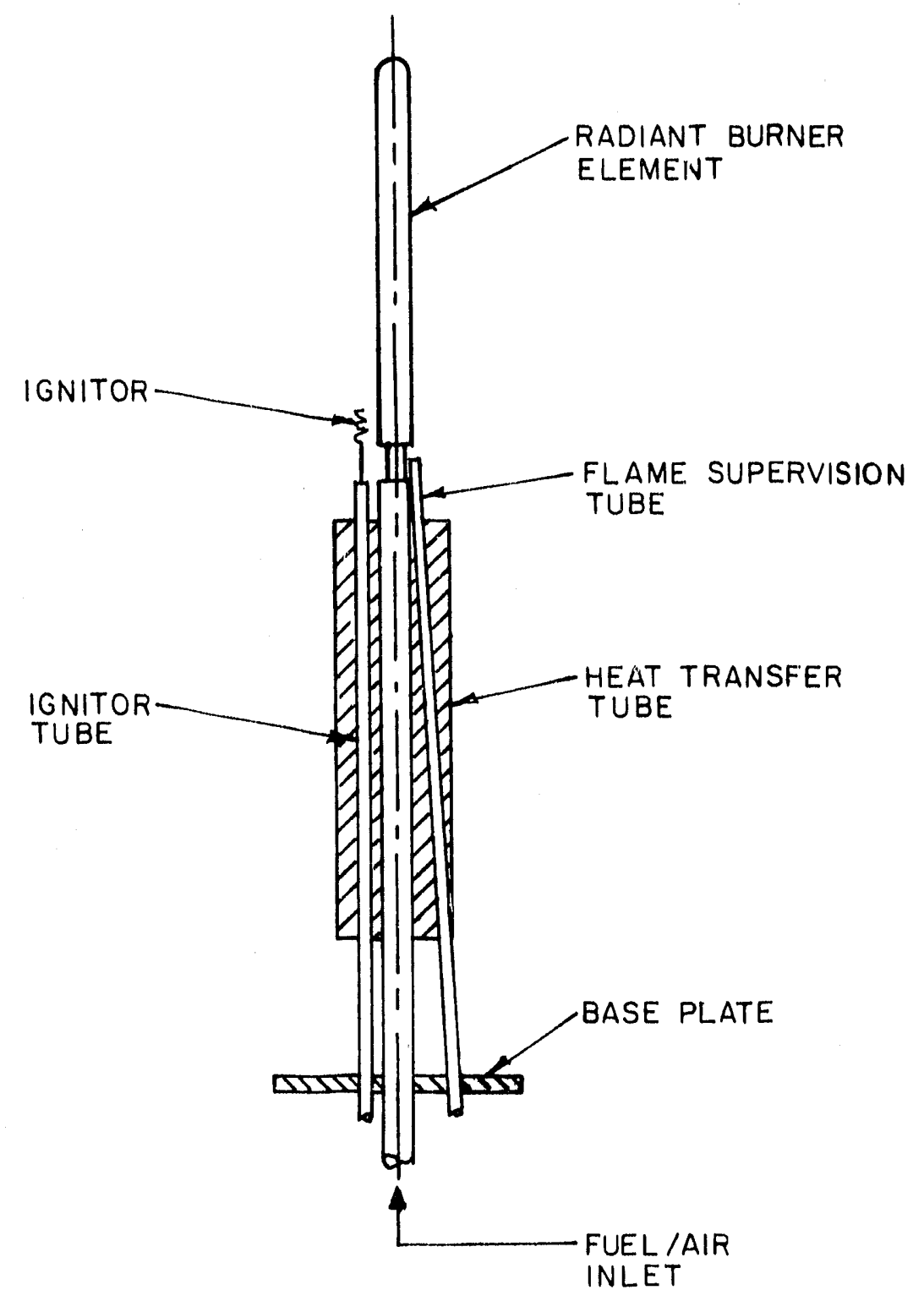

FIGURE 30 -REFORMER BURNER ASS'Y 
Within the steam loop, the flow-sensing device was found to give readings higher than actual, due to condensation in the trap located just upstream of the reformer and downstream of the flow sensor. This problem was overcome by relocating the sensor downstream of the trap. Also, during a run aimed at operating the reformer at faster fuel feeds, the two natural gas flow sensors malfunctioned. Interference with the turbine-type rotation of the sensors was found in both the process feed sensor and the burner feed sensor; they were sent to the manufacturer for repair.

Hydrogen generation tests up to full load (about 250 standard cubic feet, or 7200 liters, of methane per hour) and beyond started in January 1988. Flow rates were taken as high as $110 \%$ of design values; $\mathrm{CH}_{4}$ conversion rates were in the 95-97\% range, slightly above the specification.

The improved insulation above and around the reformer was essential to achieving these favorable results. However, the process gas reformer inlet temperatures remained unacceptably low. This appeared to be due to residual heat losses at the reformer base and at adjacent flanges and piping. For the longer term, this will require better thermal integration among the reformer and adjacent units; in the meantime, besides further upgrading of the insulation, resistive heating was used on the piping leading to the reformer so as to achieve the design inlet temperature of $700^{\circ} \mathrm{F}$ (about $370^{\circ} \mathrm{C}$ ). This allowed the catalyst bed exit temperature to reach the desired values without a faster than normal fuel feed to the burner.

In February 1988, the reformer ran at $100 \%$ and $110 \%$ of rated throughput, each time with two separate steam/fuel ratios $(3.0$ and 3.5 moles $\mathrm{H}_{2} \mathrm{O} / \mathrm{mole} \mathrm{C}$ ). At first, these runs inadvertently used peak-shaved fuel; this fuel, consisting of 2:0.5:0.5 natural gas/propane/air by volume, is supplied by the gas utility when it expects the 24-hour average temperature to fall below $20^{\circ} \mathrm{F}$. (Notification is normally sent under such circumstances but was not received in this case.) Methane concentrations in the exit gas ranged up to $0.6 \%$ (well within the acceptable range), with the temperature of the reformer at the exit of the catalyst bed controlled at about $1400^{\circ} \mathrm{F}$.

Corresponding runs were later conducted with unadulterated natural gas; the results were similar to those obtained on peaked-shaved fuel. In addition, the shift converter was brought on line for the first time during these runs; it ran successfully, with the exit co concentrations remaining below $0.5 \%$. On the other hand, the pressure-drop through the reformer catalyst bed was higher than normal during these runs, possibiy because of the prior operation on peak-shaved fuel. 
A steaming run was carried out, in accordance with the catalyst manufacturer's instructions, in an attempt to reduce reformer catalyst bed pressure-drop to previous values (by eliminating any build-up of carbon deposits within the bed). This procedure succeeded in lowering the pressure drops; however, the catalyst activity, although still acceptable, fell as a result of this treatment. At rated throughput, the methane concentration in the reformer catalyst bed exit gas was just over $1.0 \%$.

To determine the reformer's tolerance to insufficient heat, two runs were conducted in April 1988 at the following operating points:

1) At rated feed flows to the reformer and rated fuel flow to the reformer burner.

2) At $110 \%$ of rated feed flows to the reformer and rated fuel flow to the reformer burner.

Run 1 served as a control, while Run 2 was used to test under insufficient heat. The results are summarized below.

Run (1)

Run (2)
Catalyst Bed

Exit Temp.

$$
\frac{1375-1400^{\circ} \mathrm{F}}{1375-1300^{\circ} \mathrm{F}}
$$$$
1275-1300^{\circ} \mathrm{F}
$$

Methane Conc. in Exit Gas

$1.0-1.4 \%$

$2.6-3.0 \%$

These results showed that the methane slip would eventually become unacceptable without enough heat; however, a substantial fall in temperature when shifting from Condition 1 to Condition 2 was significantly delayed. Accordingly, the methane slip remained acceptable for about a half hour during the transition. These results suggested that the lag time would allow the system to run satisfactorily during suddenly and unintentionally applied disturbances.

The reformer-burner fuel feed requirement as a function of process gas feed rate was determined in May of 1988. Seven individual runs allowed burner fuel settings to be selected at any load condition. The results showed, as expected, that the ratio of burner fuel to process gas increased as the load fell from 100\% to $30 \%$ of rated; however, the increase was small, as shown in Figure 31 .

The natural gas reformer ran in the integrated mode in July 1988, as described for $25 \mathrm{~kW}$ stack No. 2, above.

\section{SUBTASK III-3 OVERALL SYSTEM ANALYSIS}

The Physical Sciences Inc. subcontract was completed in 1983 . Final reports involving the off-design and transient analysis 


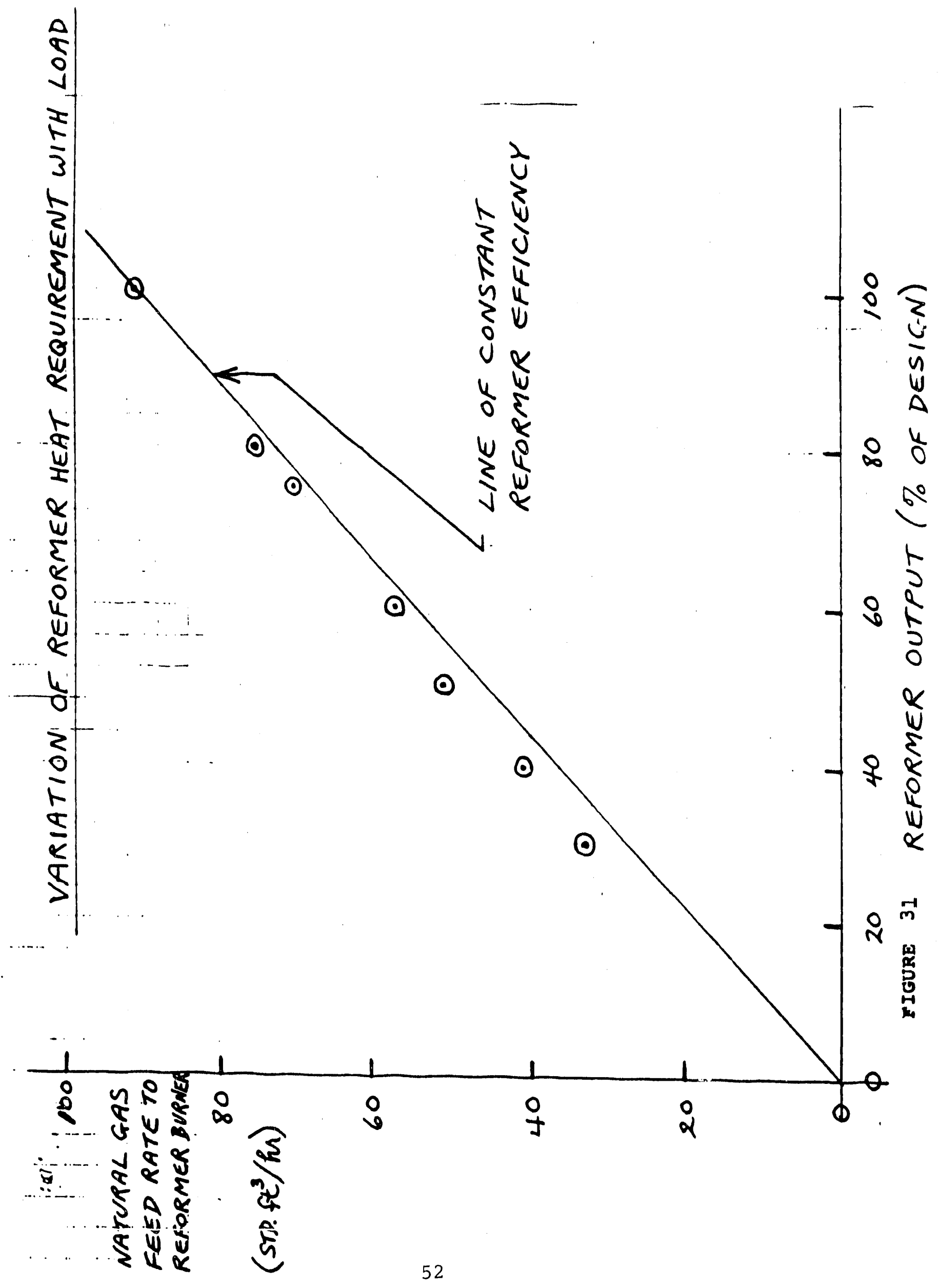


portions of the work were received at that time; the corresponding computer modules were integrated into the overall fuel cell system program, and these were successfully utilized in-house.

\section{SUBTASK III-4 OVERALL SYSTEM DESIGN AND DEVELOPMENT}

The Trane Co. Completed work in 1983 under its subcontract to Engelhard. The main conclusions of Trane's study with respect to the HVAC sub-system and the utilization of waste heat were summarized in the 1981-1984 Interim Report. Trane's results are fully described in that Company's report to Engelhard and.NASA, dated July 15, 1983 .

\section{TASK IV - STACK TECHNOLOGY DEVELOPMENT}

The purpose of this task was to investigate new materials and component concepts through bench-testing and stack trials. The criteria for selecting activities under this task were the prospects for improved performance, reduced costs, or improved reliability. Improvements in the performance of electrocatalysts generated under Engelhard-sponsored Task VI have also been reported under Task IV.

\section{A. PERFORMANCE OPTIMIZATION}

\section{Catalysts}

Larger batches (750g.) of developmental cathode catalyst E-3 and E-7 were prepared in 1984 for stack tests and single-cell evaluations.

Two cathodes with this developmental E-3 catalyst showed performance levels at or near those expected for E-3. Figure 32 shows this for cells that had run about 1000 hours and 850 hours, respectively. The corresponding voltage-current curves are shown in Figures 33 and 34 .

Two cathodes with the developmental E-7 catalyst were also tested. These, too, performed reasonably in keeping with earlier, smaller batches. The steady-load performance is shown in Figures 35 and 36 for cells that had run about 200 hours and 800 hours, respectively. The corresponding voltage-current curves are shown in Figures 37 and 38 .

Performance comparisons between cathode catalysts E-1 (baseline) and $\mathrm{E}-7$ (developmental) continued to be provided in 1983 Stack No. 3. Figure 39 shows that although losses were sustained by both catalyst types, the performance differential in 


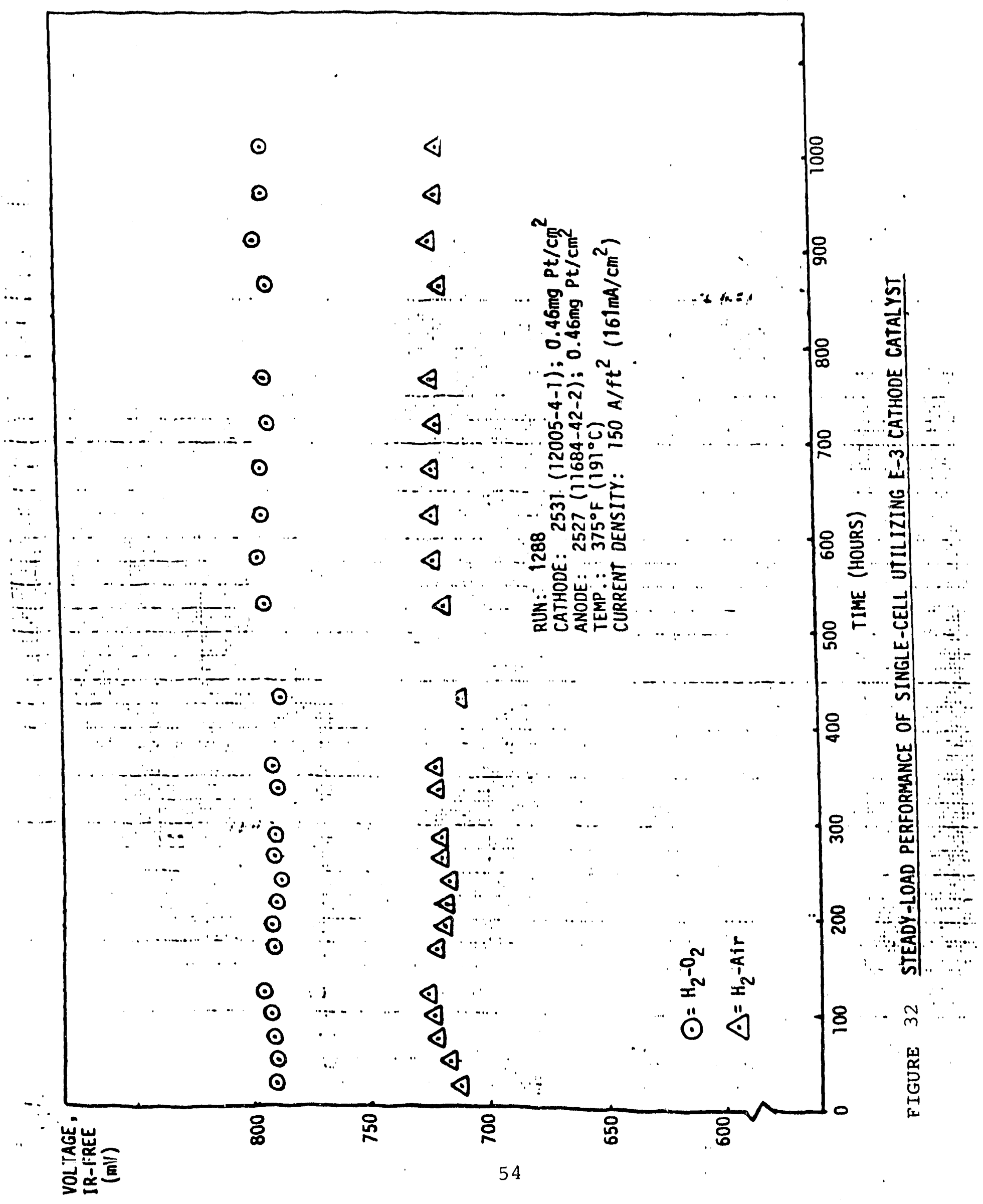




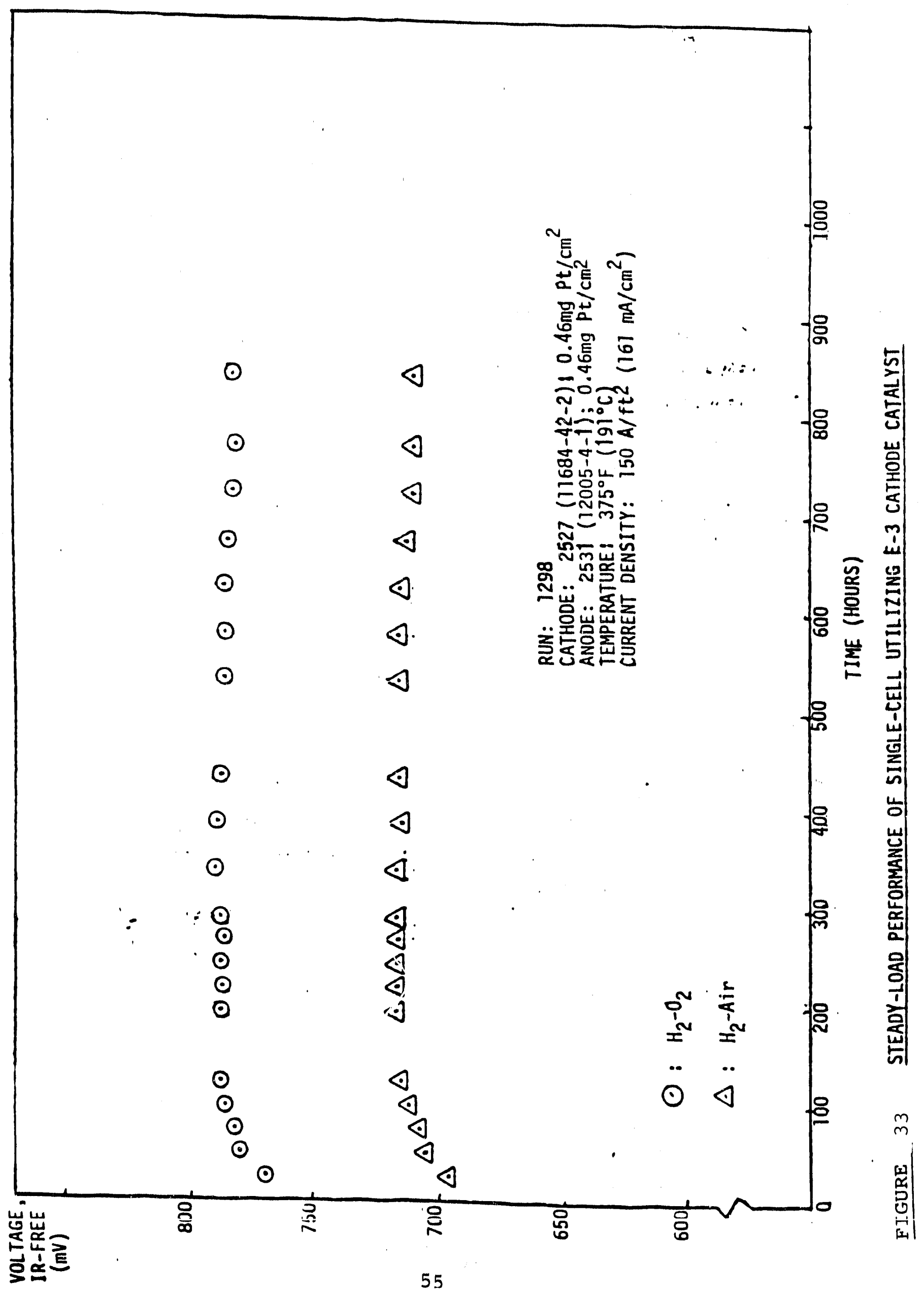




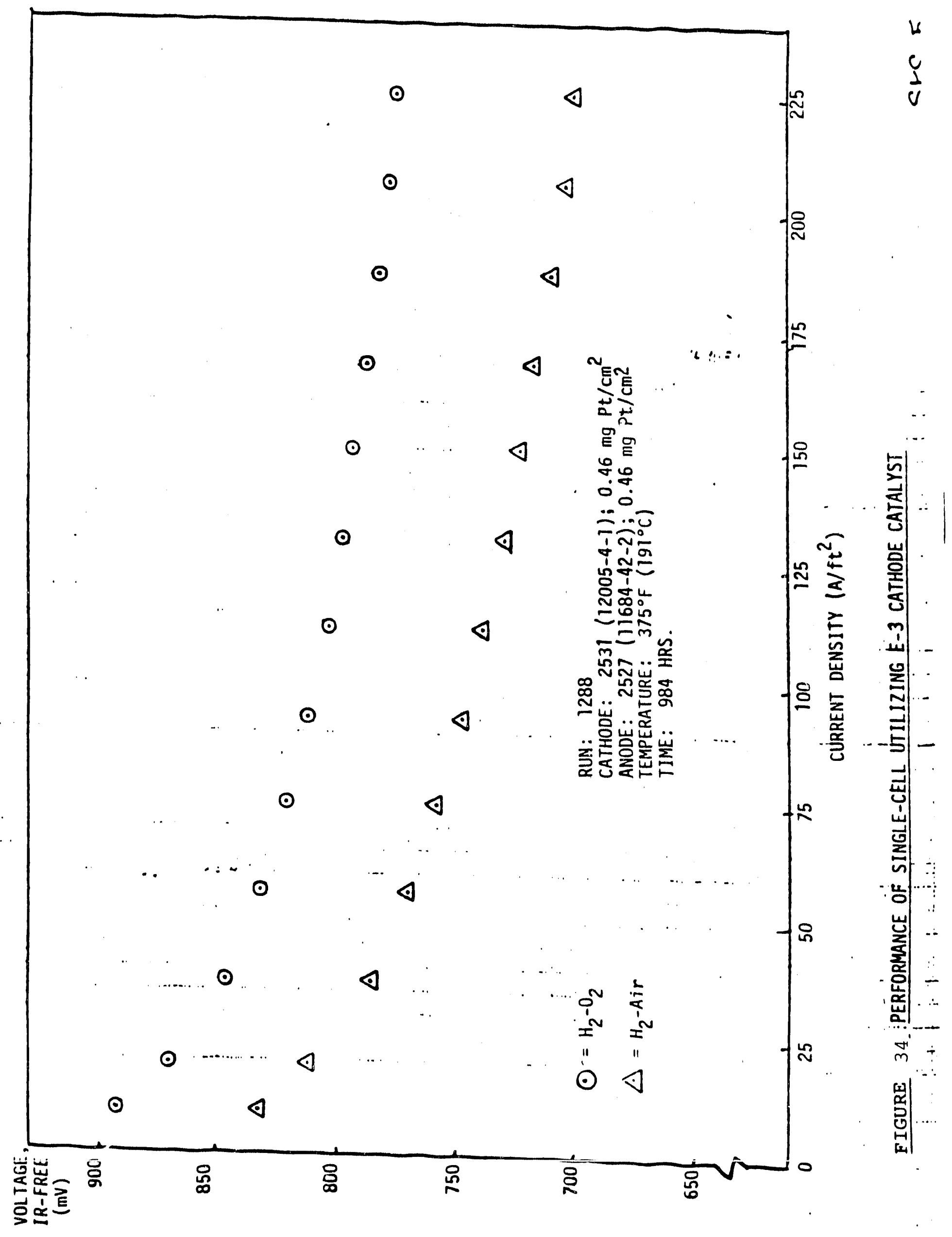




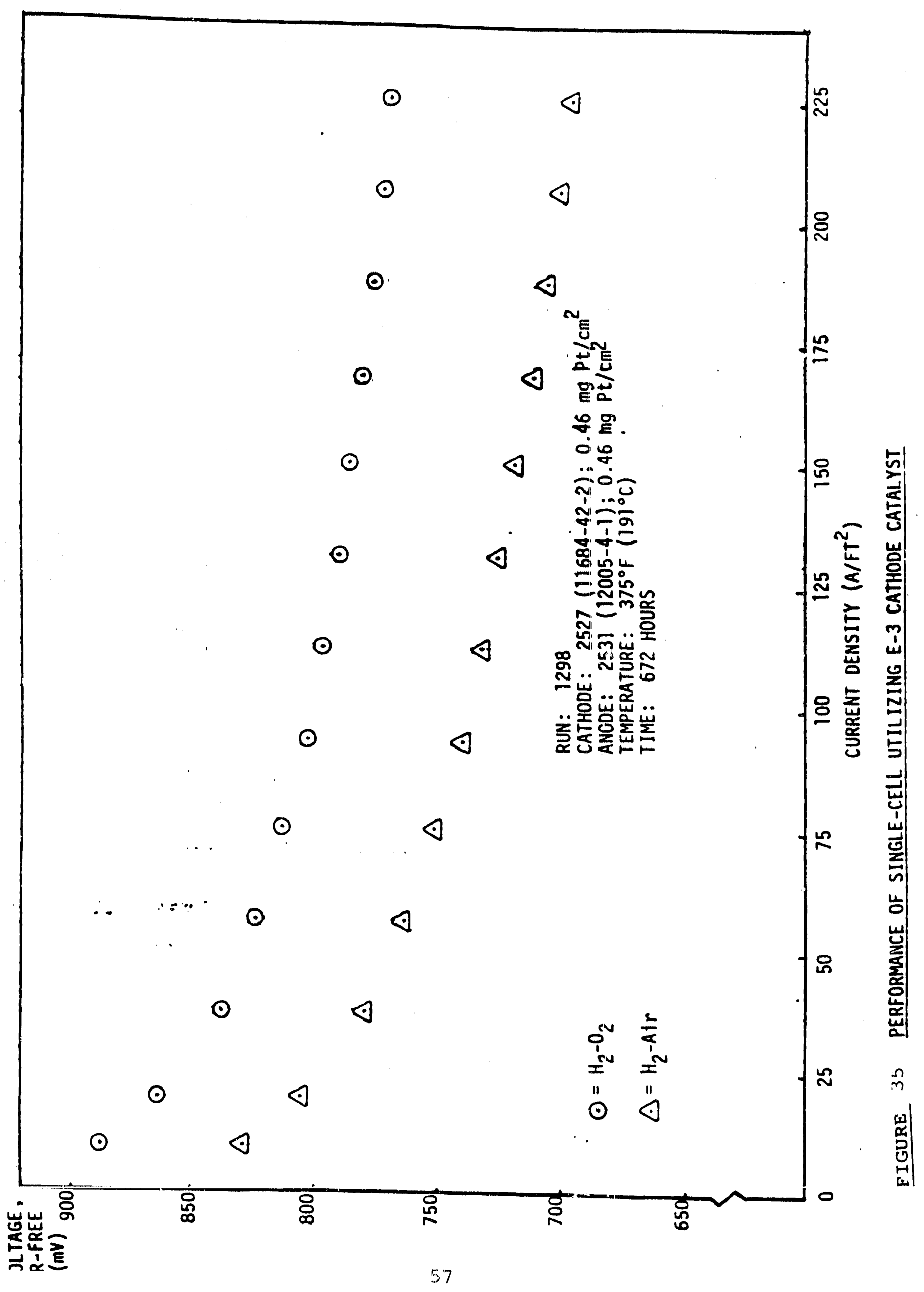




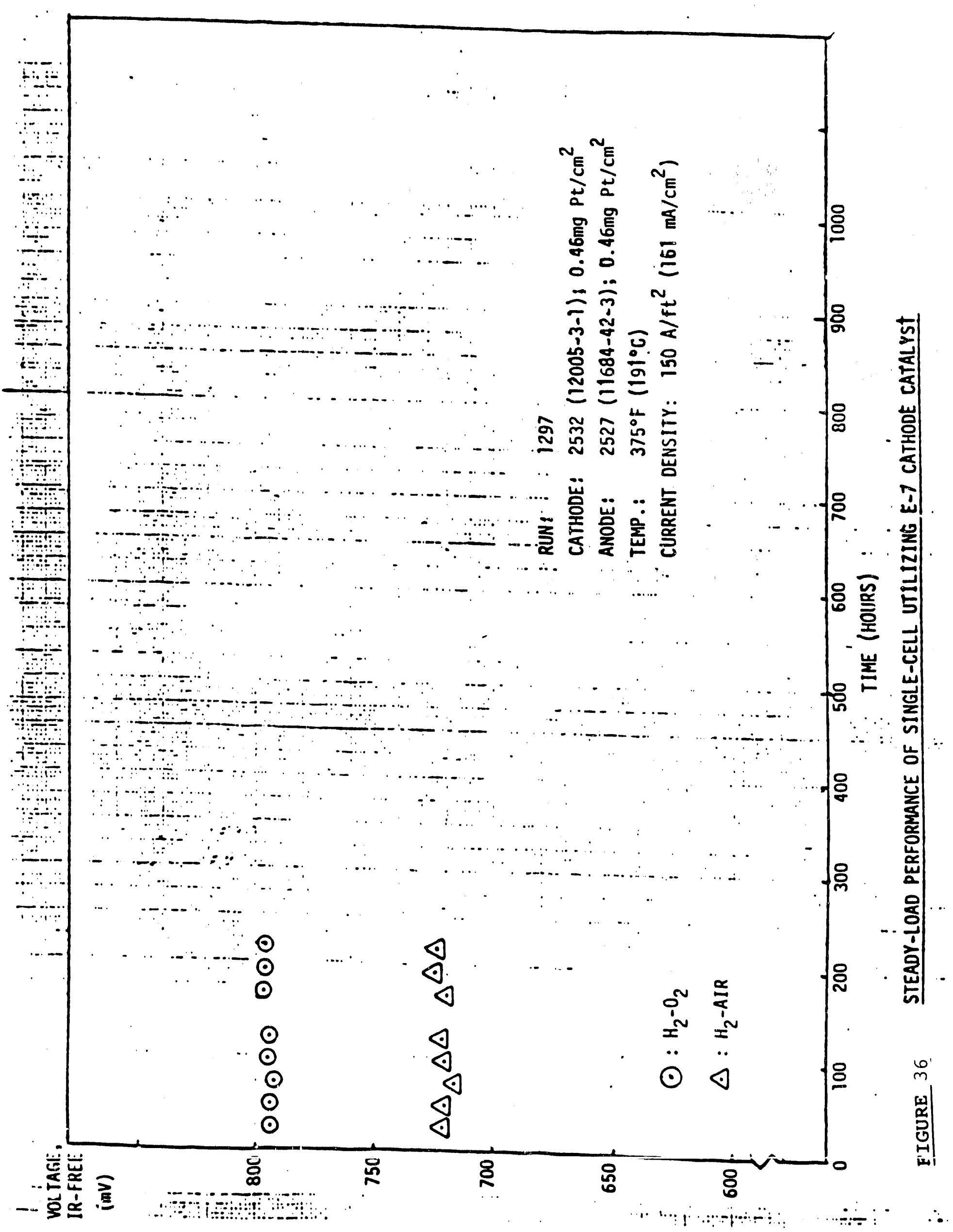




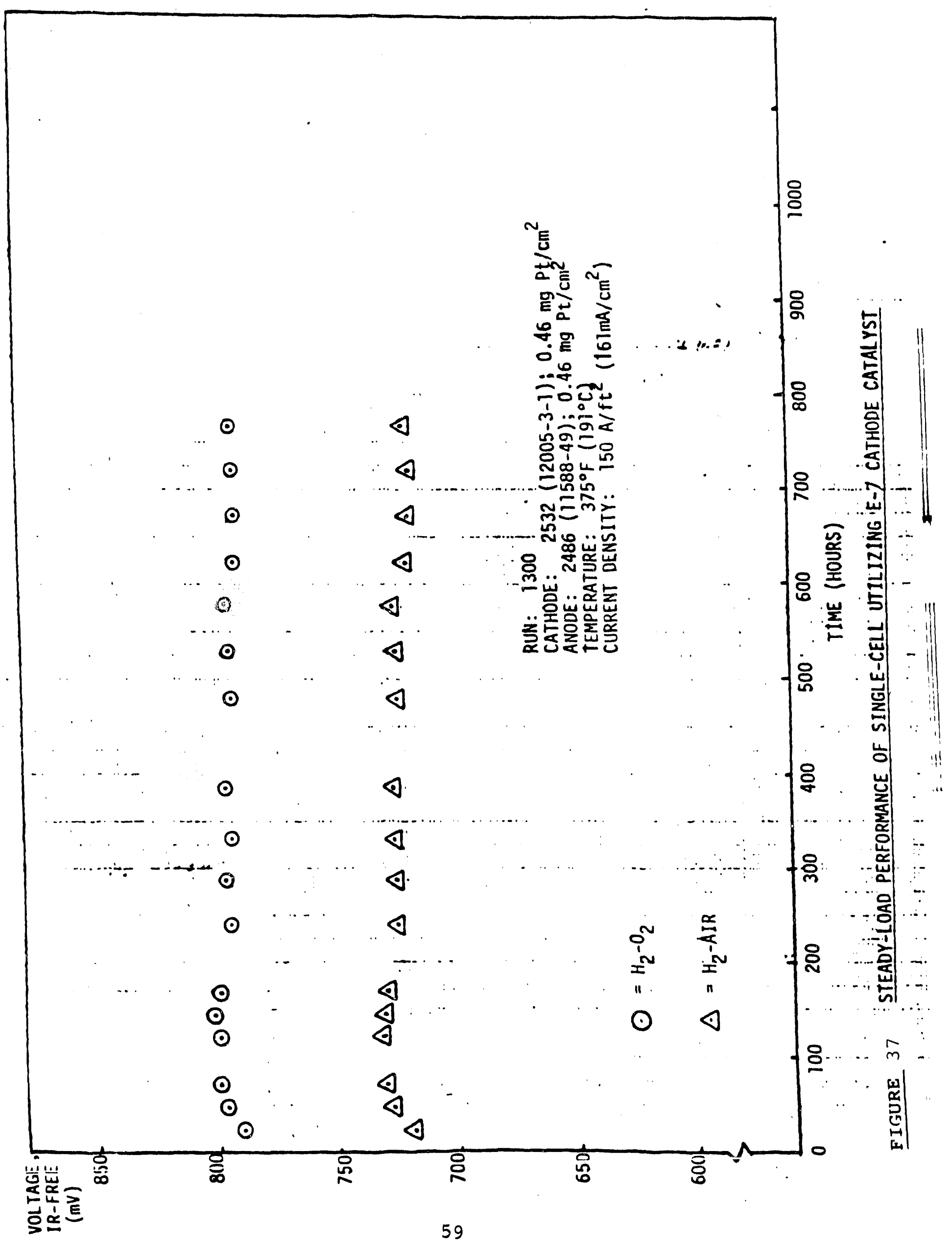




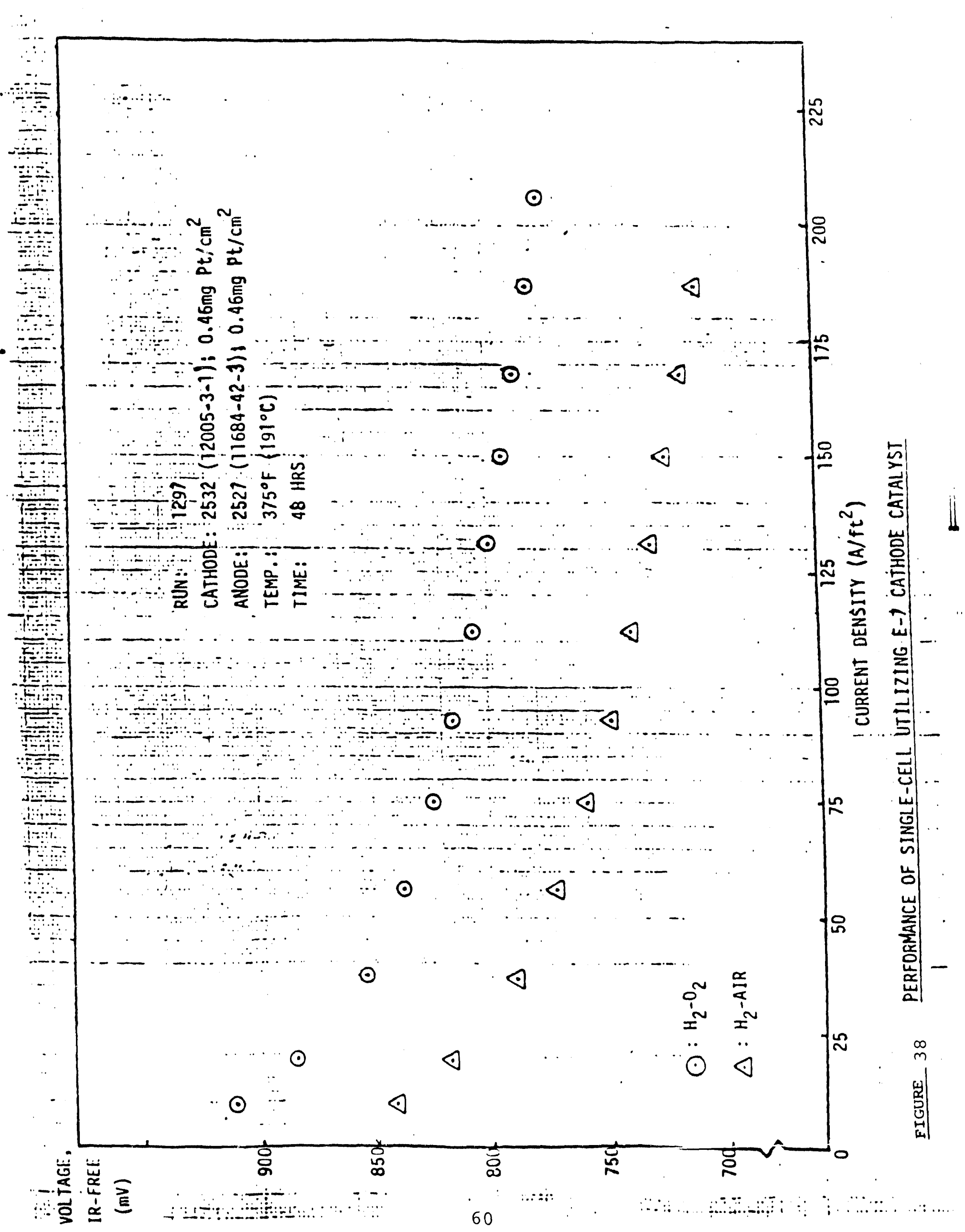




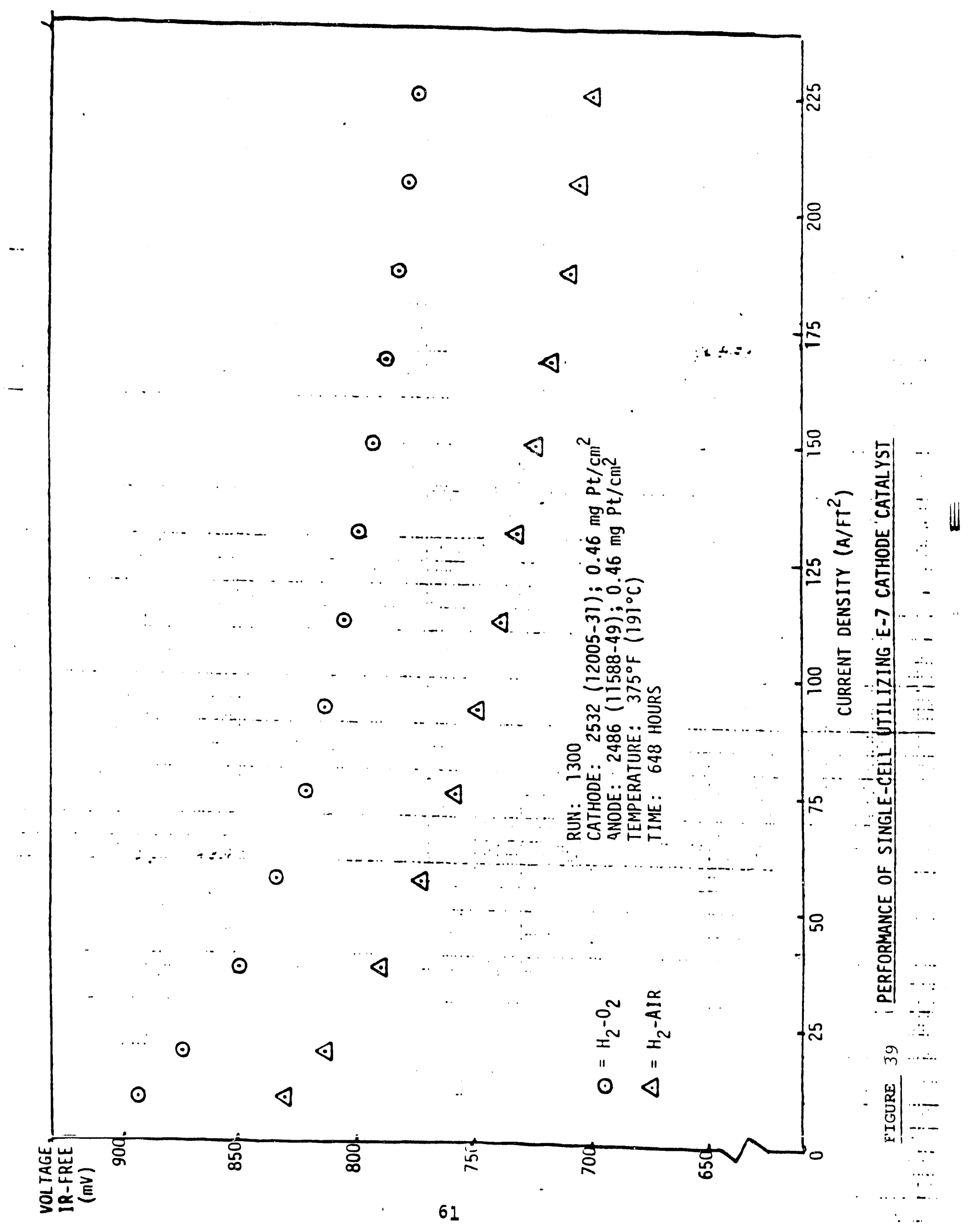


favor of E-7 was sustained through about 4800 hours. The losses were for the most part attributed to hot open-circuit exposure following house power outages and subsequent fuel supply interruptions, as indicated by the vertical arrows in Figure 40.

A performance comparison between the two developmental cathode catalysts $(2-3$ and $\mathrm{E}-7)$ was also provided through the testing of stack No. 1 and stack No. 2 in the 1984 series. The average disparity of performance between the two cathodes was about $15 \mathrm{mV}$ for Stack No. 1 (about 4000 hours) and about $10 \mathrm{mV}$ for stack No. 2 (about 2900 hours), each in favor of $E-7$.

Engelhard's standard A-1 anode catalyst was heat-treated at $900^{\circ} \mathrm{C}$ under $\mathrm{N}_{2}$ and evaluated as a cathode in single-cells and by cyclic-voltammetry (Figs. 41 and 42 and Table II). The results showed that, although the platinum surface area of the catalyst and the B.E.T. surface area of the carbon support were significantly reduced after heat-treatment, the single-cell performance of this electrode (as a cathode) improved by $19 \mathrm{mV}$ ( 150 ASF, $\left.191^{\circ} \mathrm{C}, \mathrm{H}_{2} / \mathrm{air}\right)$. The stability of the heat-treated catalyst also improved markedly. After 3100 hours, the performance was $0.686 \mathrm{~V}$ IR-free at $161 \mathrm{~mA} / \mathrm{cm}^{2}$ and $191^{\circ} \mathrm{C}$.

A new batch of ternary cathode catalyst (E-8) was then tested in a single-cell. Compared to the corresponding binary catalyst $(E-7)$, it showed an improvement of about $20 \mathrm{mV}$ (average of two cells each); one comparison can be seen in Figure 43. However, the binary catalyst performed about 20-30mv lower than typical.

Meanwhile, the $900^{\circ} \mathrm{C}$ heat-treated platinum-only cathode catalyst on an anode-type carbon black support continued on load in a single-cell for more than 4000 hours. Although its performance was particularly stable at $0.703 \mathrm{~V}$ IR-free at $161 \mathrm{~mA} / \mathrm{cm}^{2}$ and $191^{\circ} \mathrm{C}$ over the first 2200 hours, substantial decay took place afterward. The cell was shut down after 4440 hours because of an accidental reactant gas cross-over. Performance prior to shutdown had been $0.662 \mathrm{~V}$ IR-free at $161 \mathrm{~mA} / \mathrm{cm}^{2}, 191^{\circ} \mathrm{C}$. The performance history is shown in Figure 44 .

Another E-8 tri-metallic cathode catalyst was evaluated in a single cell. The cell was shut down after 2808 hours because of a thermocouple failure that caused severe overheating. Its peak $\mathrm{H}_{2}-$ air performance was high at $0.73 \mathrm{~V}$ IR-free at $161 \mathrm{~mA} / \mathrm{cm}^{2}$ and $191^{\circ} \mathrm{C}$; it ran very stably before the shutdown which occurred at a voltage of $0.714 \mathrm{~V}$. The performance history is shown in Figure 45 .

This encouraging cell was rebuilt using the same cathode catalyst and put on test. The peak performance of the rebuilt cell was still attractive at $0.729 \mathrm{~V}$ IR-free $\left(\mathrm{H}_{2}-\mathrm{air}\right)$ at $161 \mathrm{~mA} / \mathrm{cm}^{2}$ and $191^{\circ} \mathrm{C}$; however, its stability was far worse than that of its 


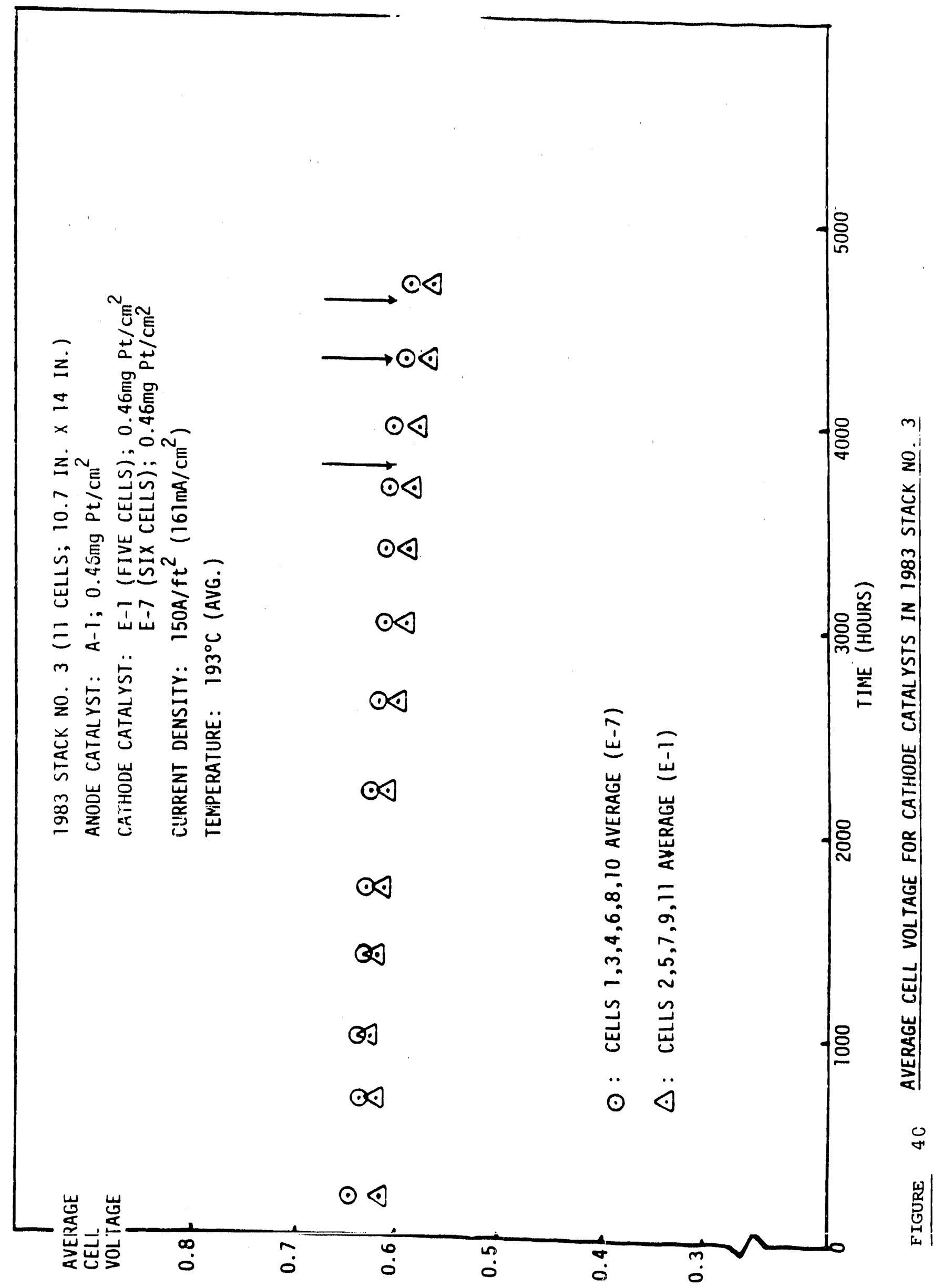



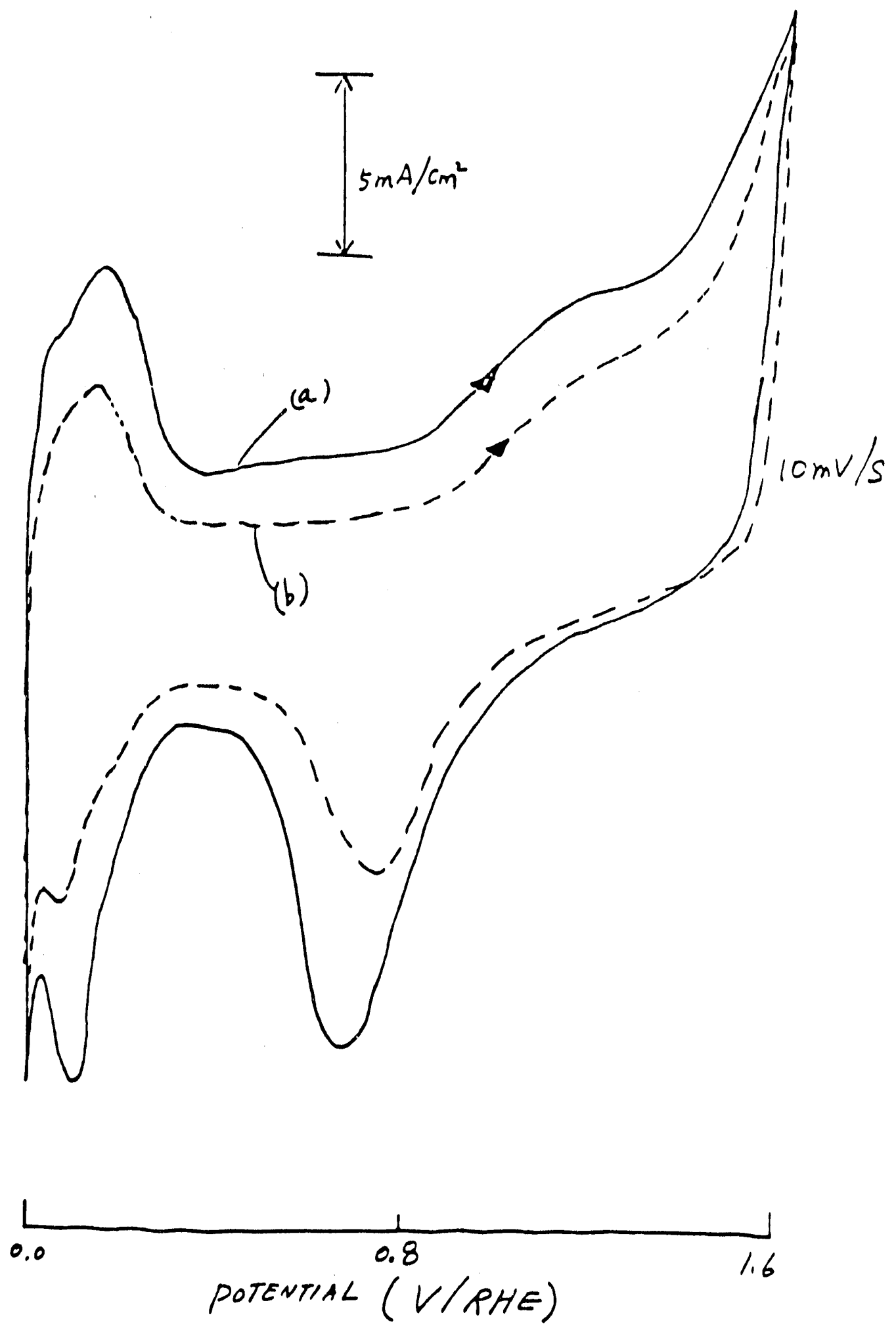

FIGURE 41

VOLTAMANGRAMS FOR ELECTROOES IN $25 \%$ H HFOA

(A) BEFORE AND (B) AFTER $900^{\circ} \mathrm{C}$ HEAT-TREATMENT 


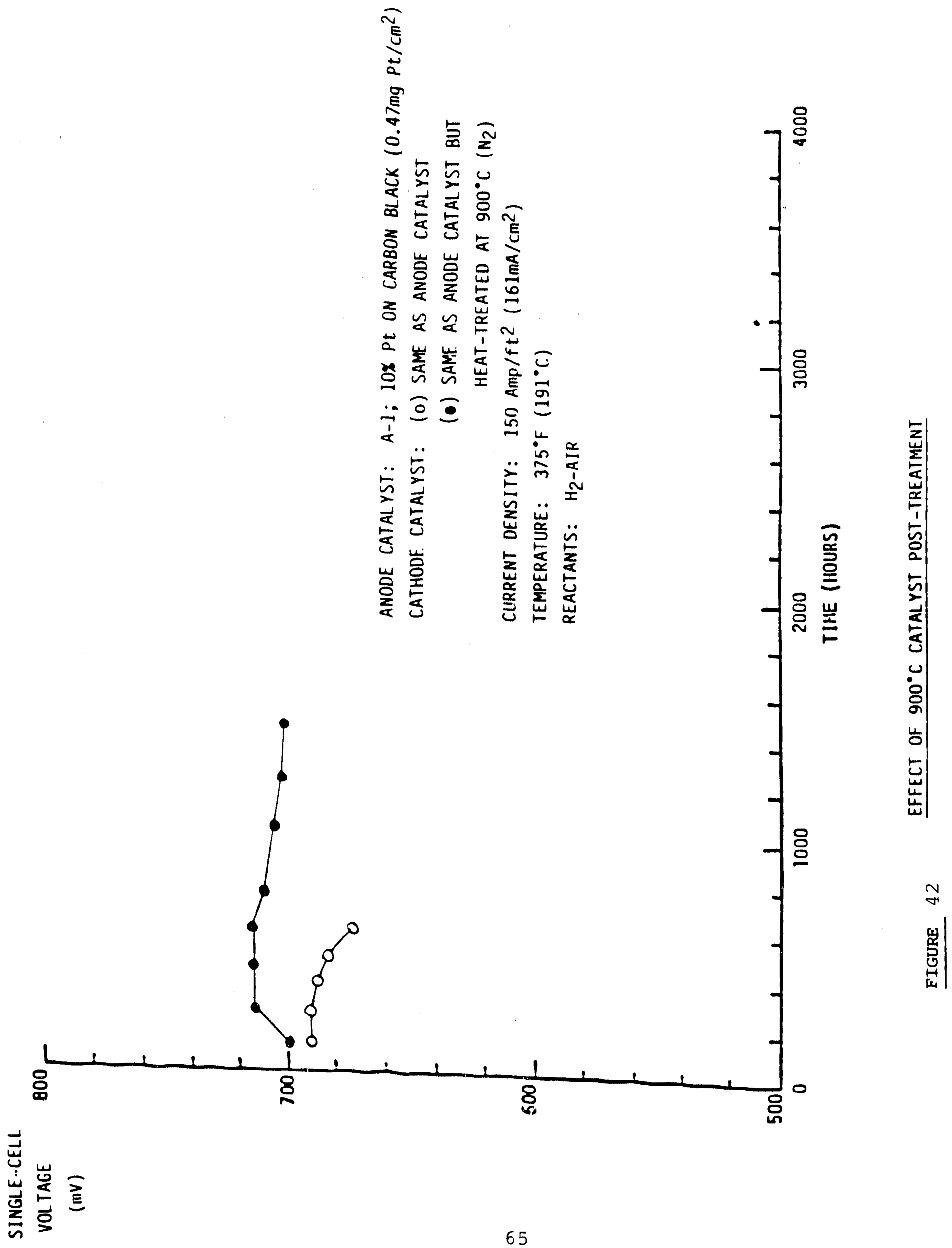




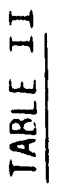
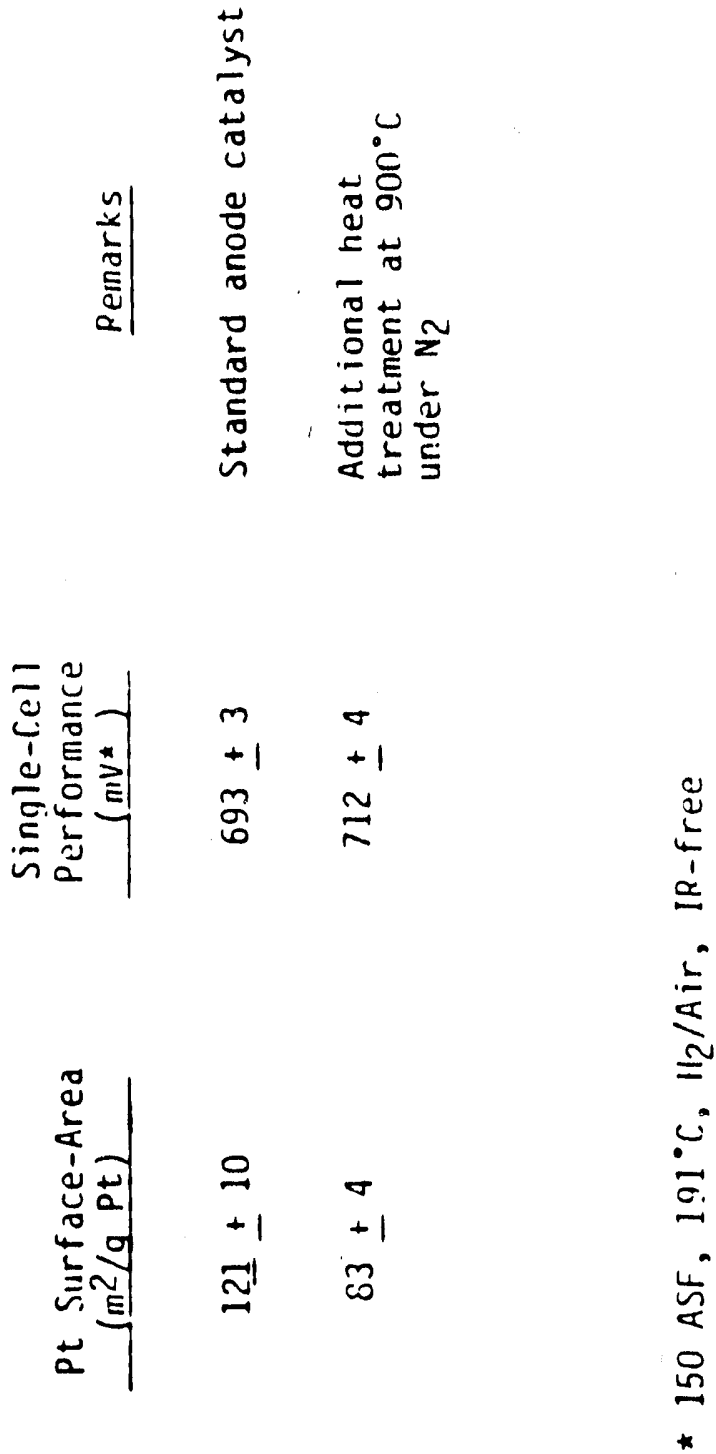

部

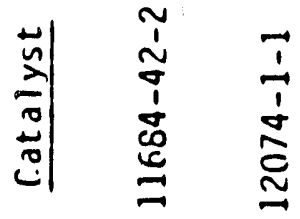




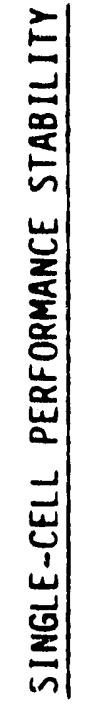

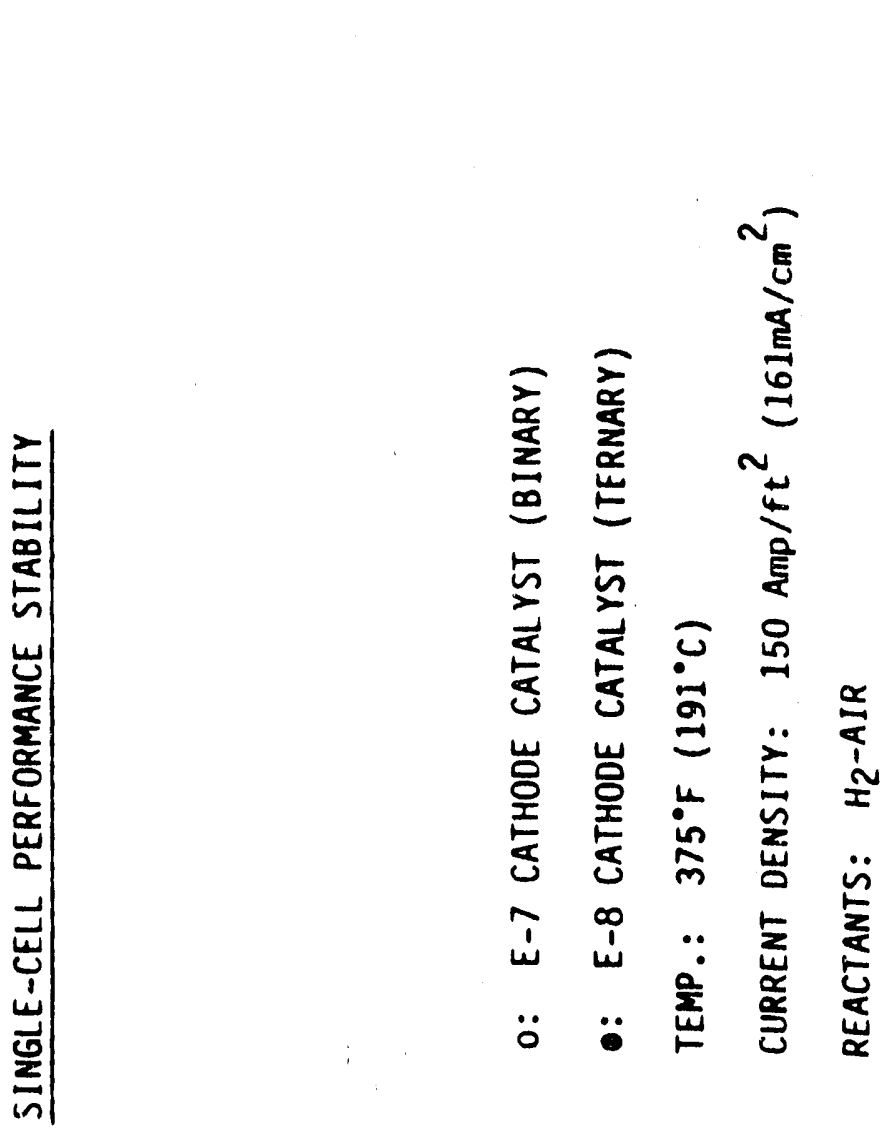

$m$
+
0
0
0
0
01
01

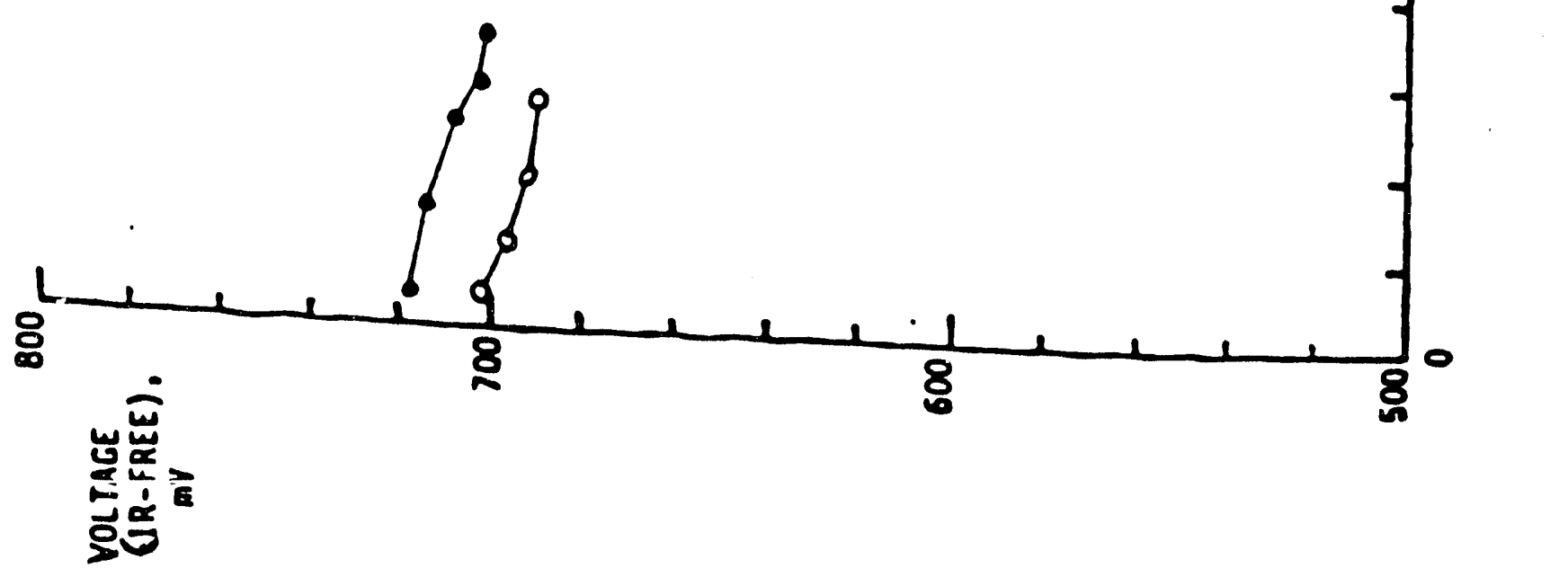




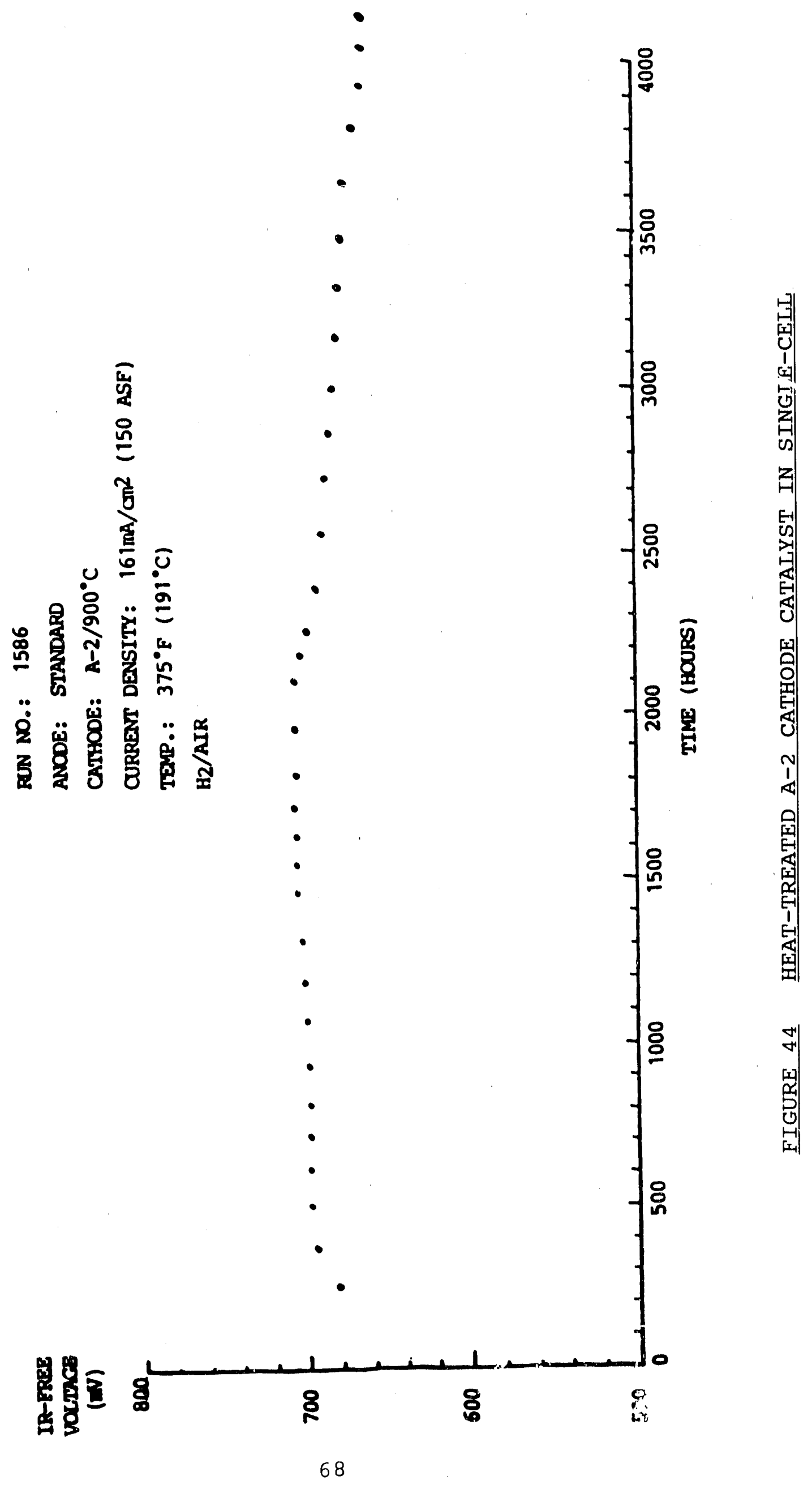




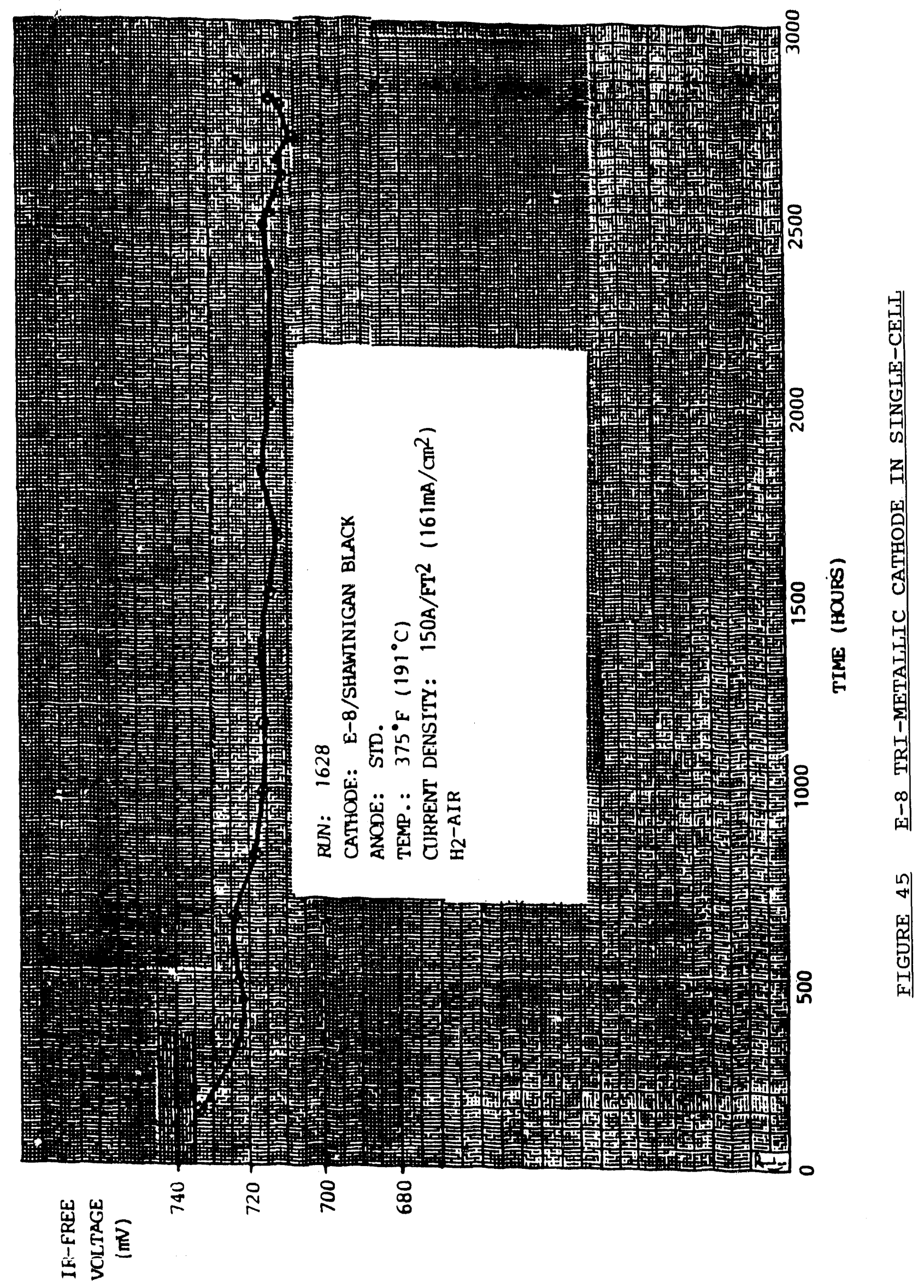


predecessor. It was shut down after 2930 hours on load, when its performance was down to $0.679 \mathrm{~V}$ IR-free $\left(\mathrm{H}_{2}-\mathrm{air}\right)$ at $161 \mathrm{~mA} / \mathrm{cm}^{2}$ and $191^{\circ} \mathrm{C}$. Another cell using the E-7 bimetallic counterpart of this catalyst showed a corresponding performance of $0.700 \mathrm{~V}$ after 2800 hours. (See Figure 46.)

Another tri-metallic cathode catalyst formulation designated E-9 (based on the E-3 precursor) was also evaluated. Its peak performance was $0.728 \mathrm{~V}$ IR-free at $161 \mathrm{~mA} / \mathrm{cm}^{2}$ and $191{ }^{\circ} \mathrm{C}$.

The cell was shut down after 3408 hours on load with a performance of $0.671 \mathrm{~V}$; it was replaced with a similar E-9 preparation, which also showed poorer stability than its bimetallic counterpart.

This cell was shut down after 2200 hours on load. The performance history is shown in Figure 47 .

Long-term single-cell evaluations were carried out for the E-3 bimetallic catalyst. Results for two such cells, each using Gulf Acetylene Black as the cathode catalyst support, are shown in Figure 48. One cell was shut down after 4180 hours due crossleakage associated with the single-cell hardware, while the other continued on test. The performance of the surviving cell is shown in Figure 49 . It was $0.674 \mathrm{~V}$ IR-free $\left(\mathrm{H}_{2}\right.$-air) at $161 \mathrm{~mA} / \mathrm{cm}^{2}$ and $191^{\circ} \mathrm{C}$ at shut-down after 5032 hours on load.

Another E-3 cathode gave $0.695 \mathrm{~V}$ IR-free $\left(\mathrm{H}_{2}-\mathrm{air}\right)$ at $161 \mathrm{~mA} / \mathrm{cm}^{2}$ and $191^{\circ} \mathrm{C}$ after 2400 hours on load.

Two more single-cells were started in February 1987 to further examine the stability of the E-3 bimetallic cathode catalyst. One of these was shut down during March because of a test-fixture malfunction, but the other put out $0.700 \mathrm{~V}\left(\mathrm{H}_{2}\right.$-air) IR-free at $161 \mathrm{~mA} / \mathrm{cm}^{2}$ and $191^{\circ} \mathrm{C}$ after 2000 hours on load. The performance history is shown in Figure 50 .

The development of trimetaliic cathode catalysts was resumed in 1987 in light of the encouraging initial performance results obtained earlier. Two single-cells were started using cathodes of the E-8 type (based on E-7 bimetallic catalyst). Another singlecell test was begun to evaluate the E-9 type of cathode catalyst (based on the E-3 bimetallic catalyst). The initial performance of these cells is shown in Table III.

A single-cell test of an E-8 cathode catalyst showed high peak activity with an IR-free cell voltage of $0.734 \mathrm{~V}$ at $161 \mathrm{~mA} / \mathrm{cm}^{2}$ and $191^{\circ} \mathrm{C}$ on hydrogen-air after about 200 hours. It was running at about $0.716 \mathrm{~V}$ when a fuel supply interruption caused a severe drop in output after about 1900 hours. Thereafter, the cell improved by about $9 \mathrm{mV}$ (to $0.694 \mathrm{~V}$ ), and testing continued for a 


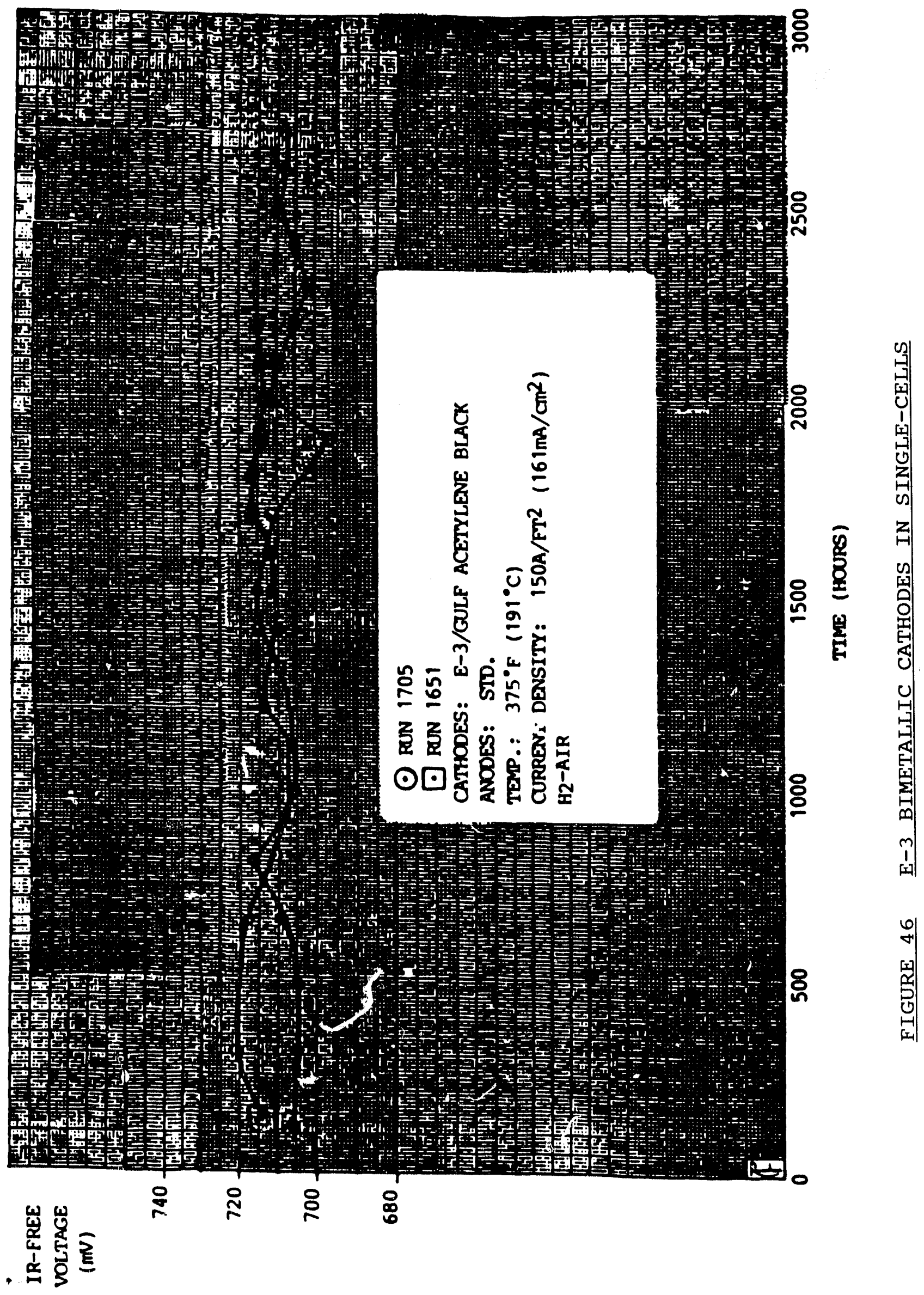




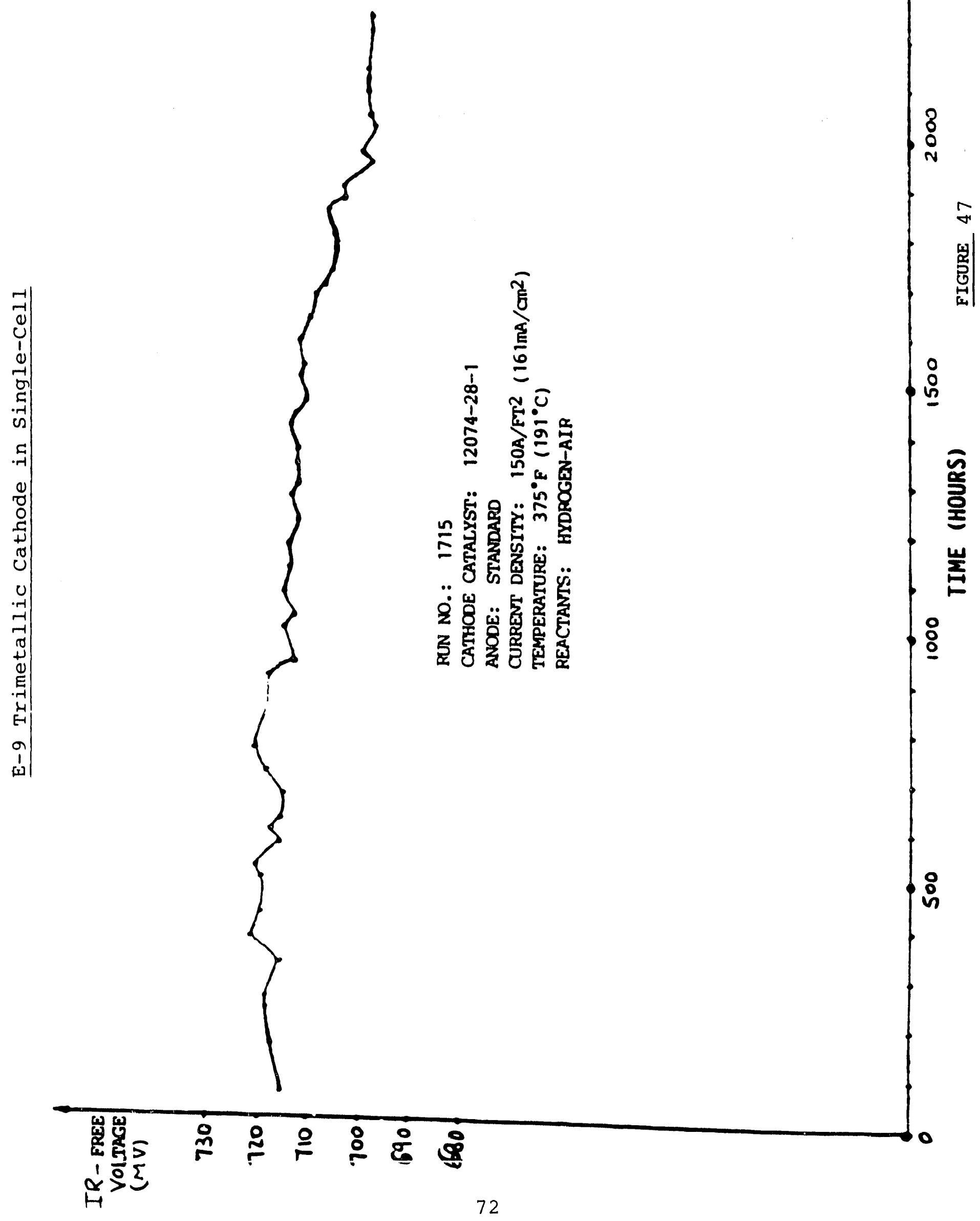




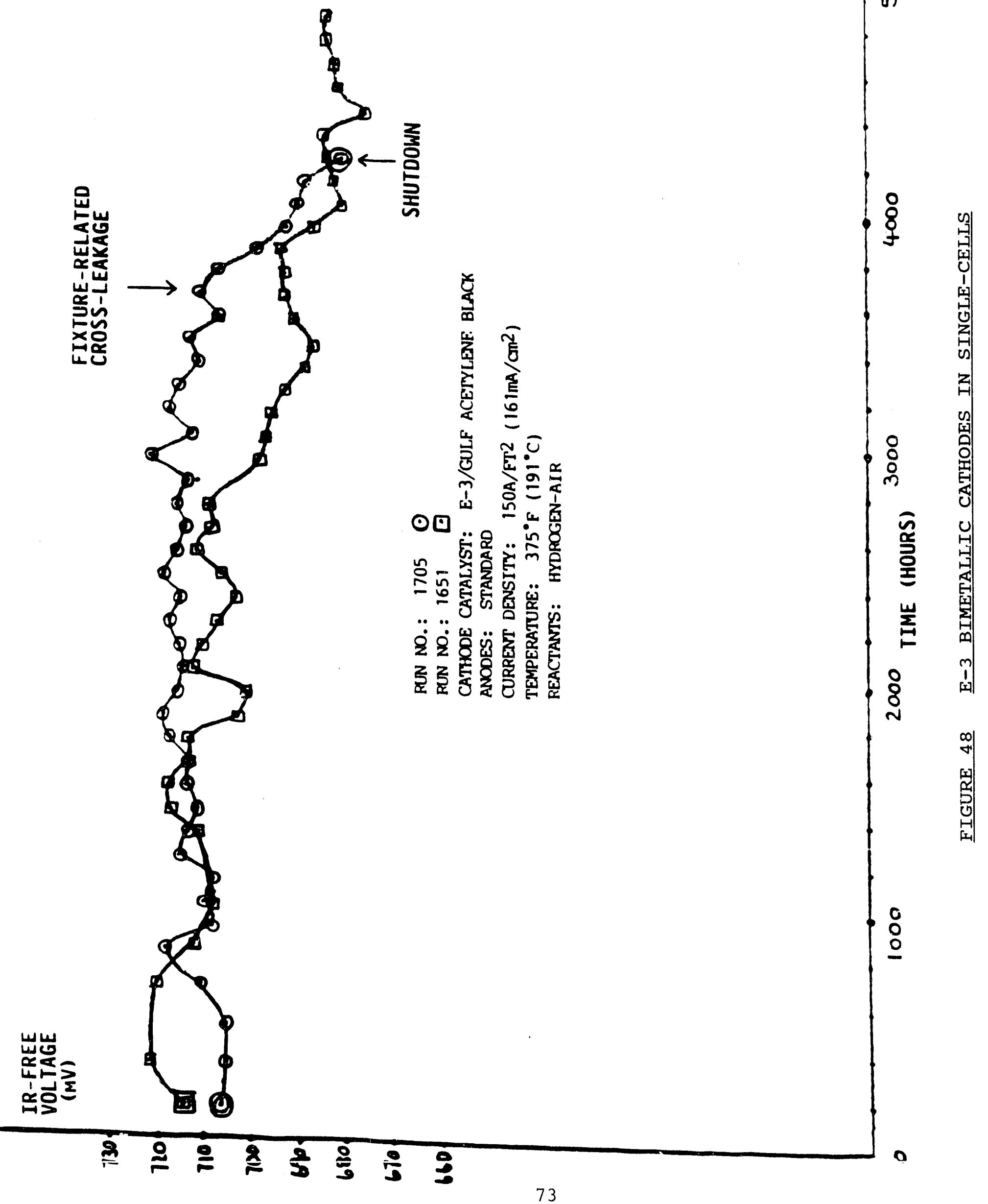




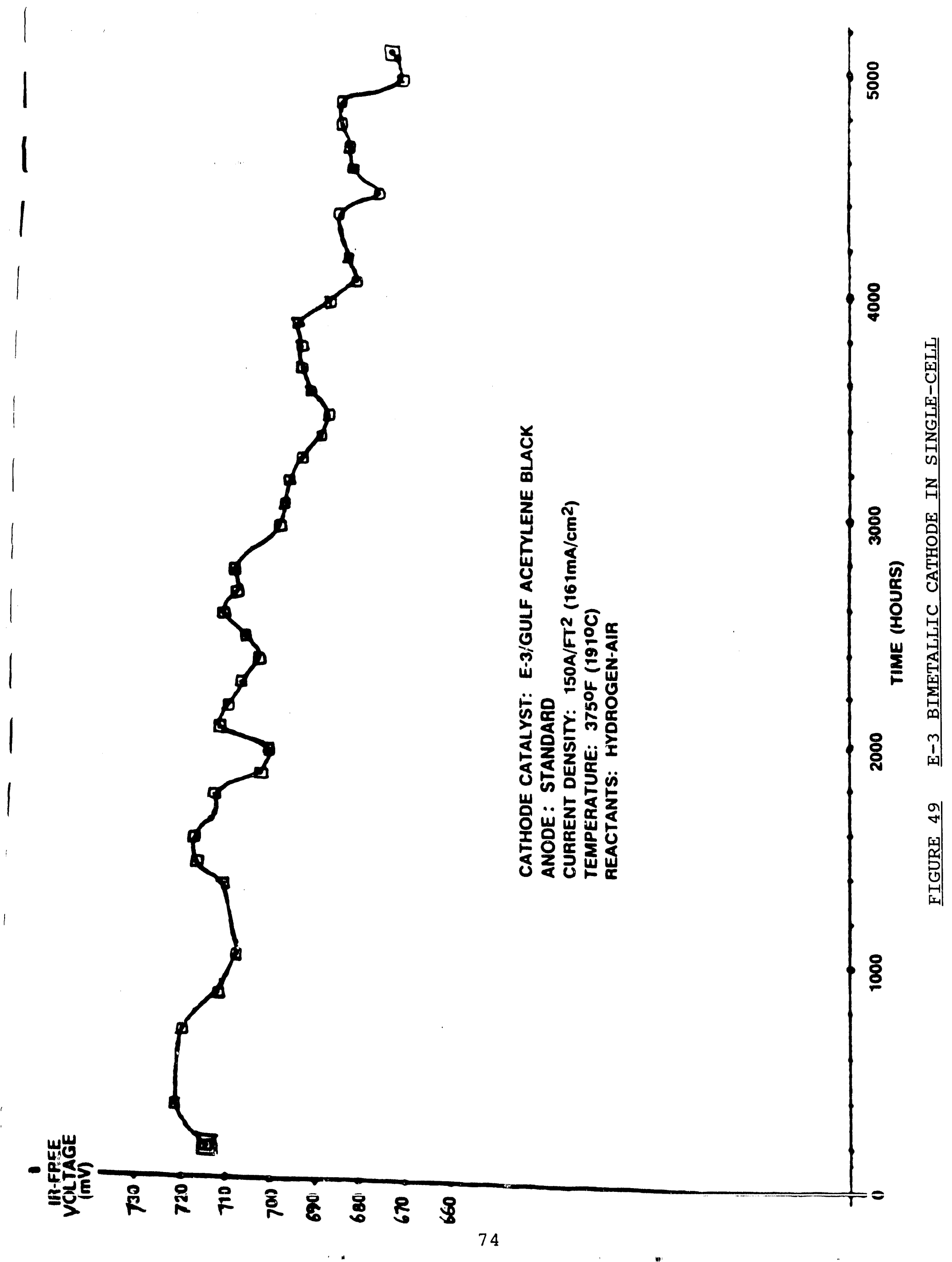




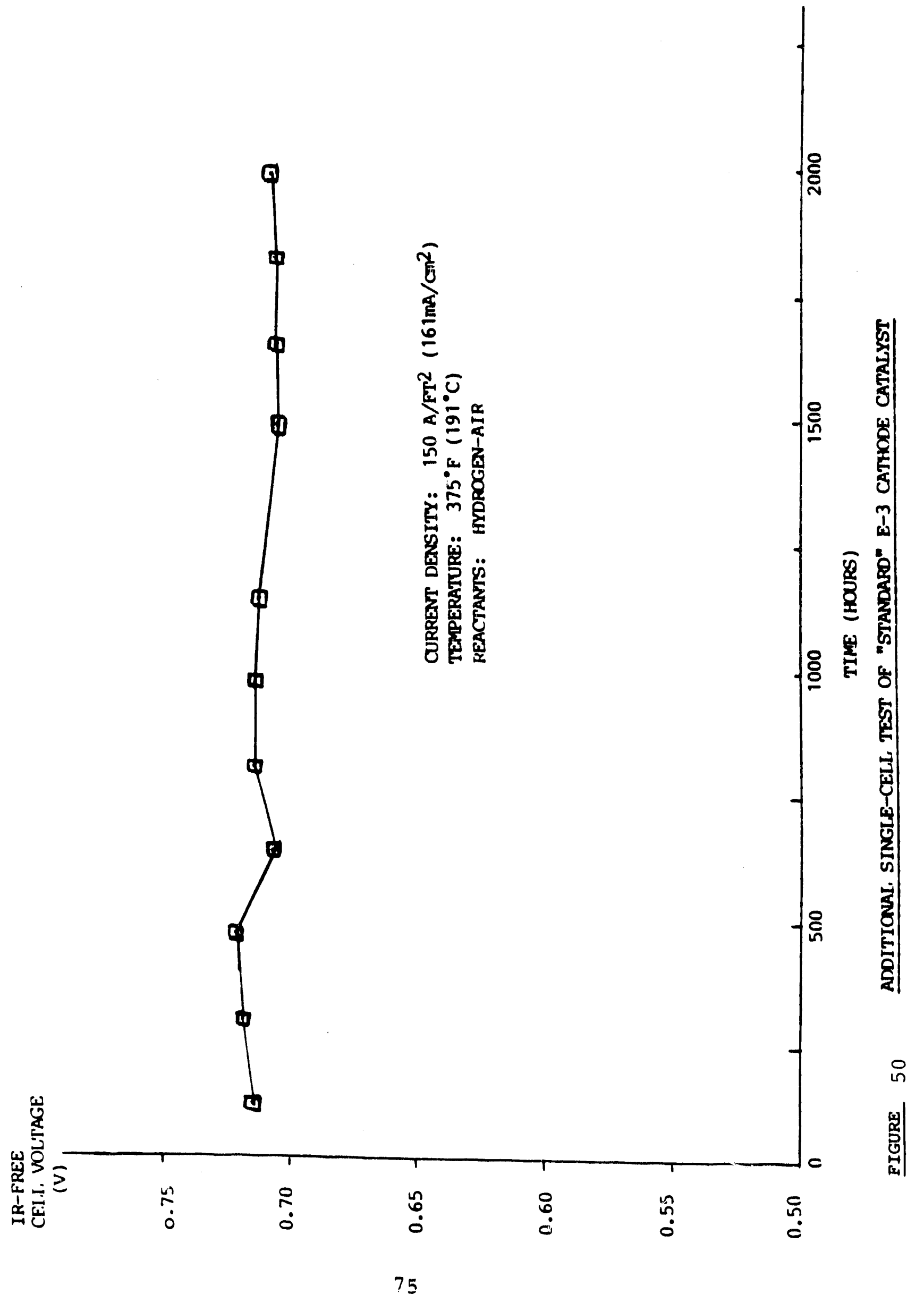




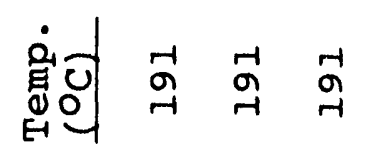

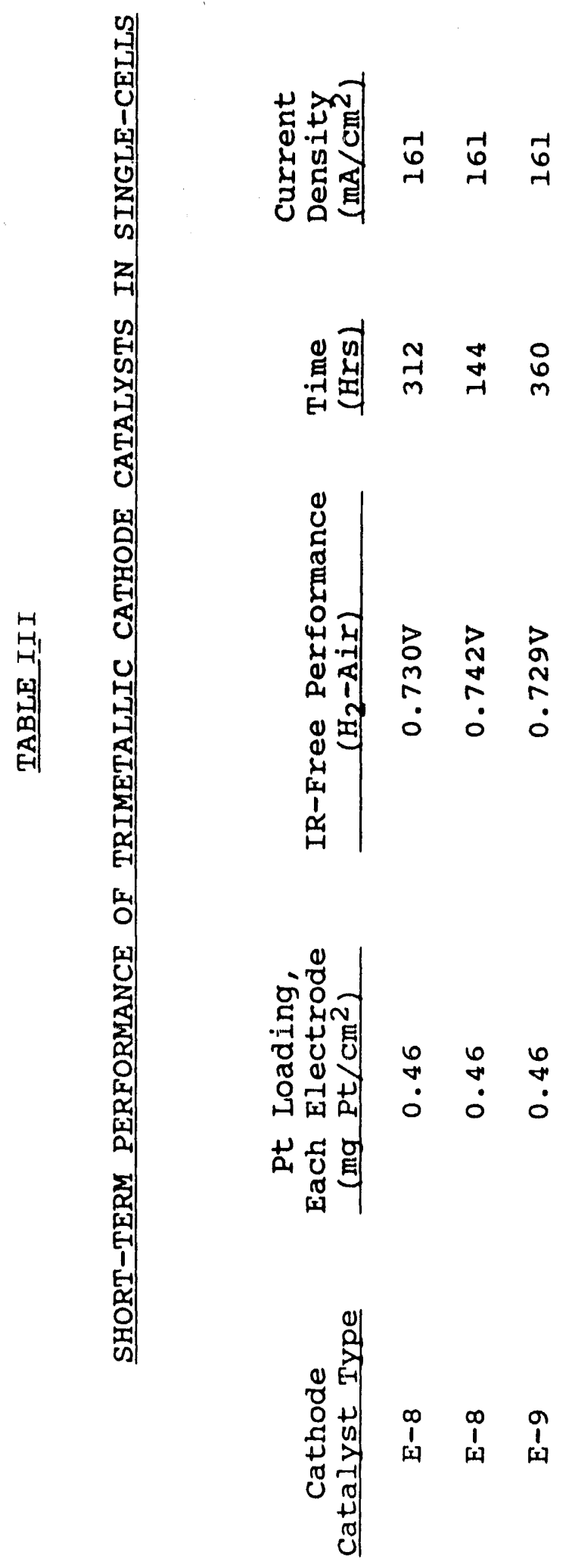


total of 2400 hours. The performance history is shown in Figure 51 .

\section{Reduced Cell IR-Loss}

Stack No. 4 in the series started in 1983 was built in January 1984 to evaluate a cell configuration that had provided reduced IR-loss in single cells $(2.75$ in. $x 2.75 \mathrm{in}$. and $10.7 \mathrm{in}$. $x 14$ in.). The configuration entailed a modification of the electrolyte-matrix, details of which are described in Appendix 1.

Stack No. 4 started on test with each of the 10 cells $(10.7$ in. $x 14$ in.) performing reasonably well, but three of these showed signs of serious electrolyte starvation after three days of operation. The stack had to be shut down shortly thereafter.

Stack No. 4 was then rebuilt and tested starting at the end of March 1984. As in the original build, this stack comprised cells with electrolyte-matrix configurations modified to achieve a lower IR-loss (See Appendix 1). The rebuild involved altered methods aimed primarily at keeping enough electrolyte in the matrix through the first few days, during which time the demand for acid by other cell components is greatest.

Although the start-up of this stack was more successful than that of the original build, two of the 10 cells were weak, apparently due once again to electrolyte starvation. operation at the normal current density $\left(161 \mathrm{~mA} / \mathrm{cm}^{2}\right)$ was therefore delayed.

The stack ran at a low current density $\left(54 \mathrm{~mA} / \mathrm{cm}^{2}\right)$ and on hot standby $\left(120^{\circ} \mathrm{C}\right.$, no load) throughout most of April 1984. The two weak cells improved over this period and full load was applied during the last week of the month. Their cell voltages remained very low (less than $0.5 \mathrm{~V}$ ), but there appeared to be signs of a further slow improvement. The overall open-circuit voltage of the stack was acceptable, though erratic, as shown in Figure 52 .

This stack showed some progress with cell IR-loss. The individual cells had losses ranging from 30 to $36 \mathrm{mV}$ at $161 \mathrm{~mA} / \mathrm{cm}^{2}$, an improvement of about $15 \mathrm{mV}$ over typical earlier stacks. The reason for the improvement can be found in Appendix 1 .

While the two weak cells in this stack had improved somewhat, their output level was still not much above $0.5 \mathrm{~V}$. The opencircuit voltage of the stack overall was still acceptable, though erratic, as shown in Figure 53 for the next 800 hours. On the other hand, the performance on load, while also erratic, clearly showed poorer stability than that of a typical stack (See Figure 54). The stack was shut down. 


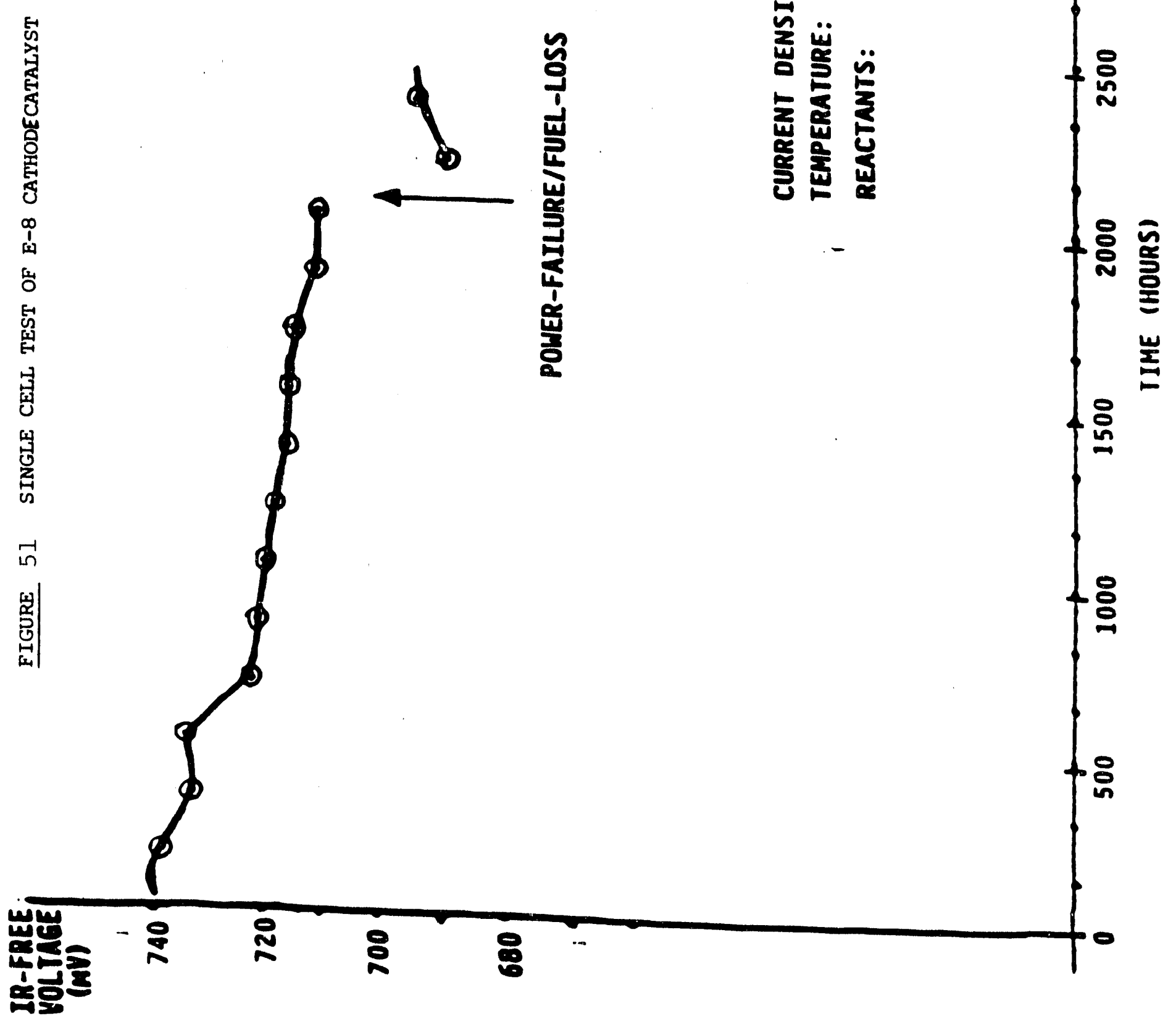




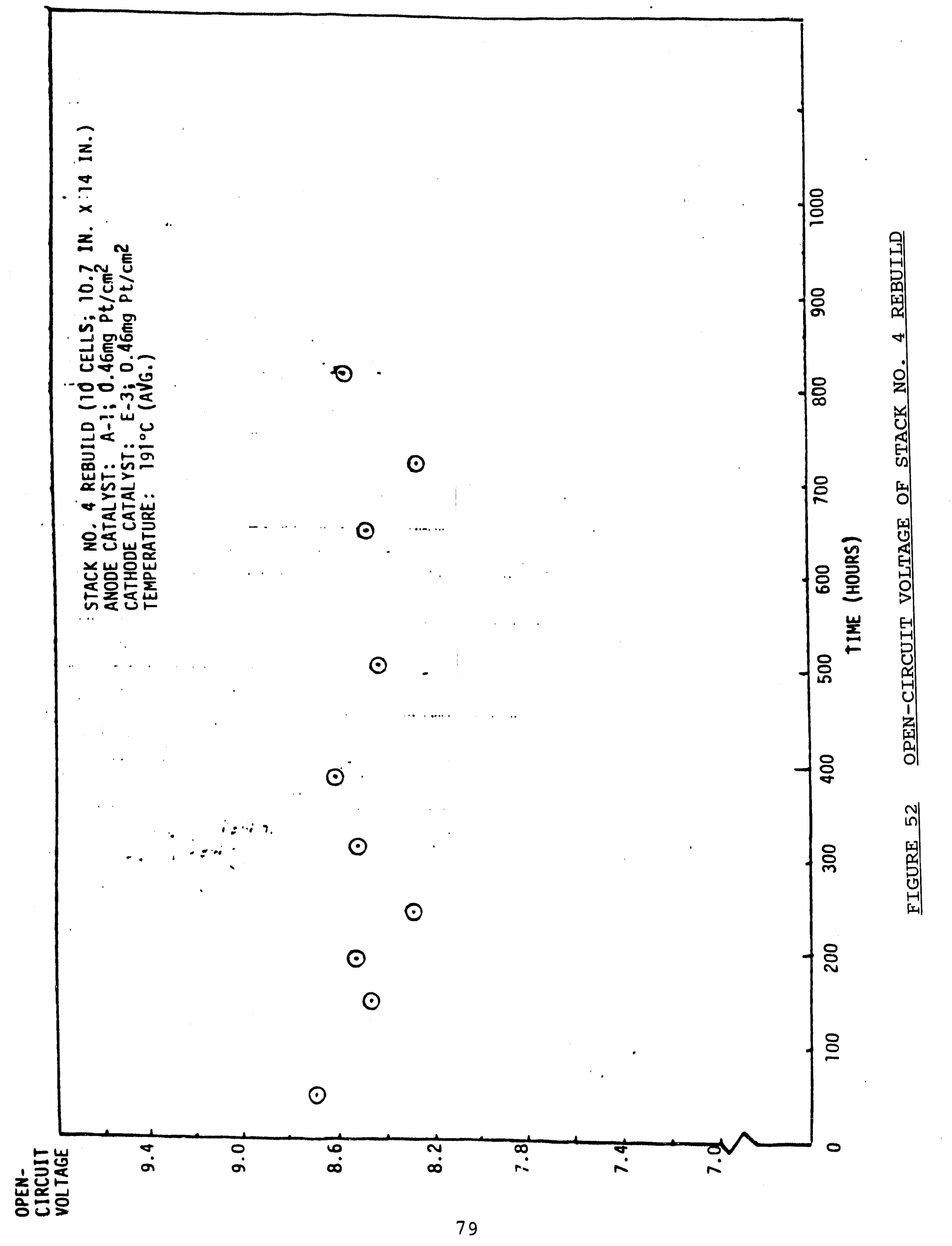




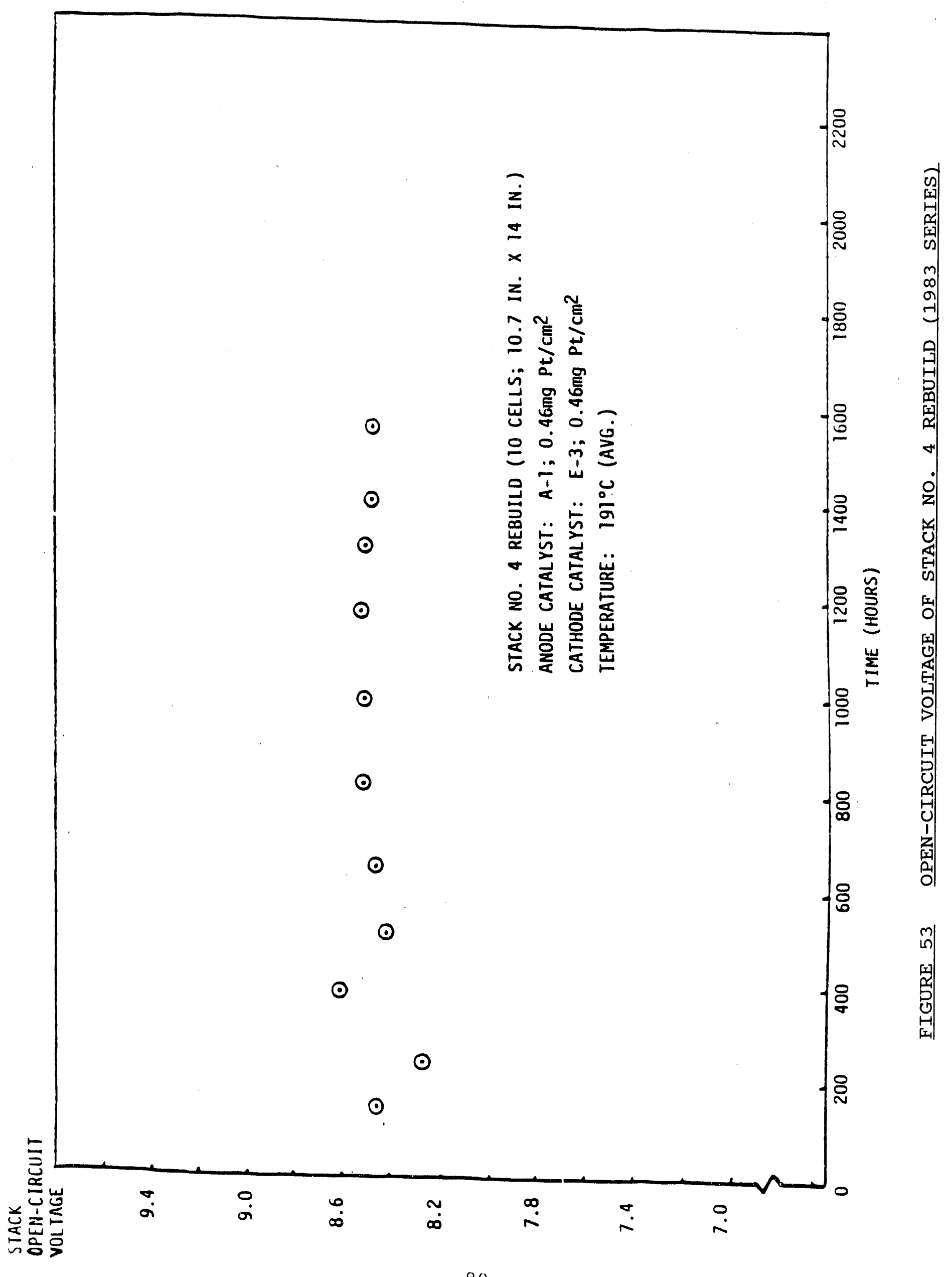




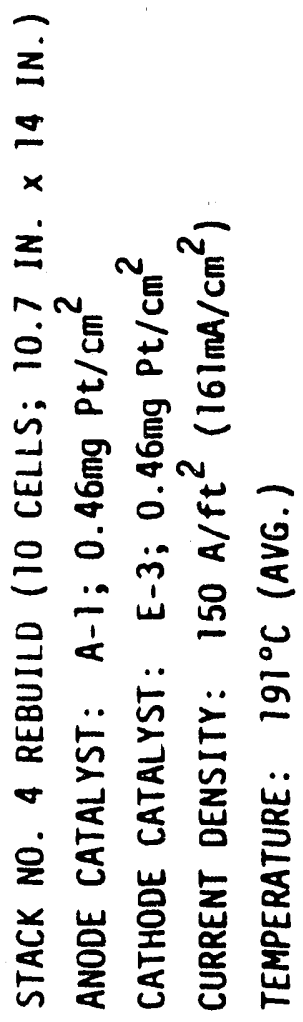

$\odot$

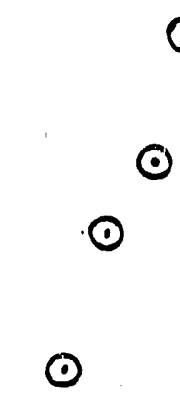

$\odot$

$\odot$

$\odot$

曾京

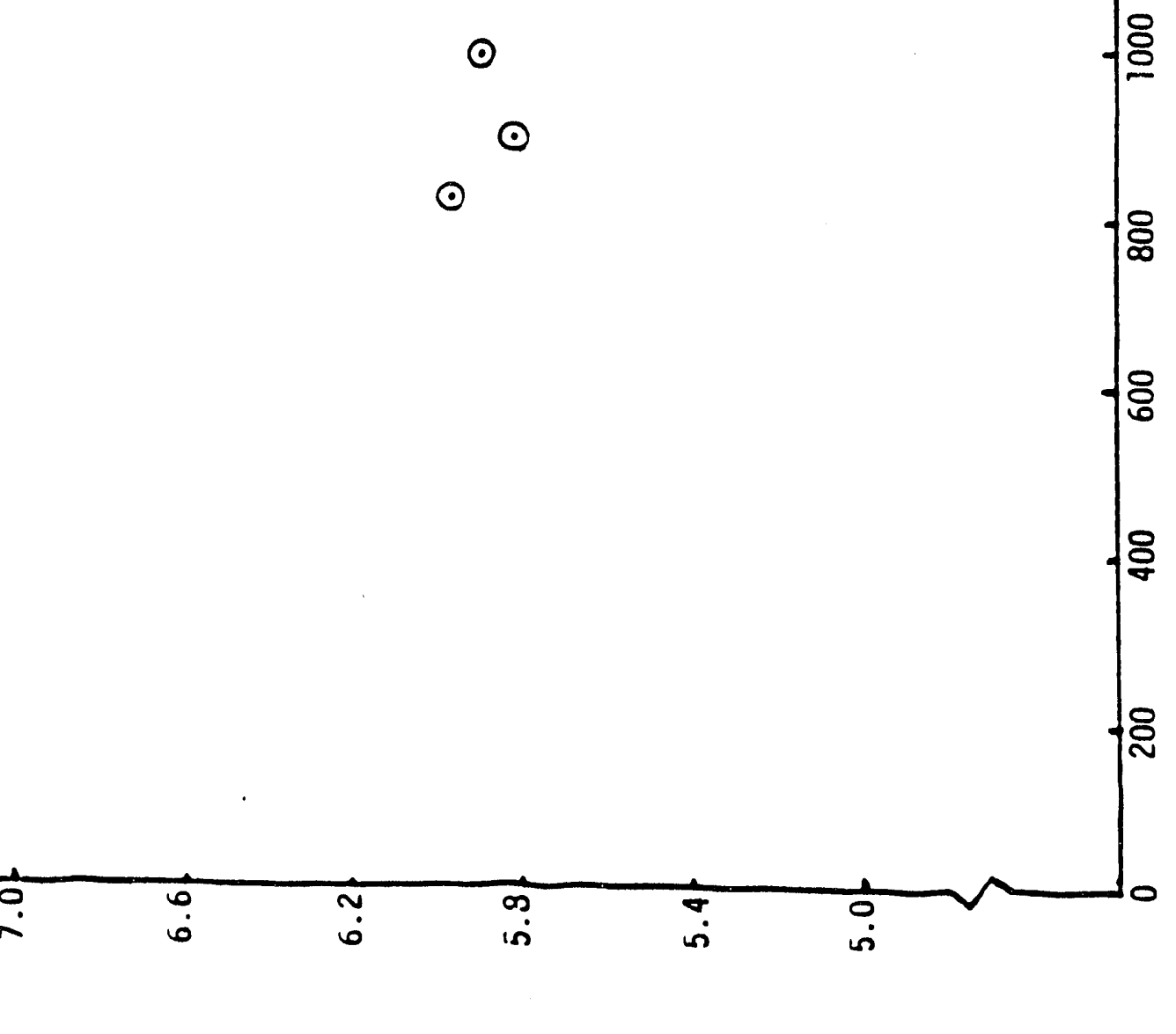


New approaches to IR-loss reduction were also tested in single-cells. Two approaches that shcwed encouraging results (24$26 \mathrm{mV}$ IR-loss a $161 \mathrm{~mA} / \mathrm{cm}^{2}$ ) are described in Appendix 1 .

\section{Alternative Acid-Transport Layer}

Alternatives that could result in a lower resistance of the electrolyte matrix were evaluated. Six stackpole Panex carbon fiber products were screened as acid-transport layers. Their corrosion rates were measured in hot $\mathrm{H}_{3} \mathrm{PO}_{4}$ in both immersion and potentiostatic tests (Table IV and Fig. 55) and compared to those of Kureha carbon paper (the standard acid-transport layer material). Panex materials KFB, PWB3, SWB8 and PWB6 appeared to resist corrosion better than Kureha paper.

A single-cell using an alternative acid-transport layer showed a peak hydrogen-air output of about $0.710 \mathrm{~V}$ IR-free at $161 \mathrm{~mA} / \mathrm{cm}^{2}$ and $191^{\circ} \mathrm{C}$, as shown in Fig. 56 , with an open-circuit voltage of $0.86 \mathrm{~V}$. Its voltage then rapidly fell to about $0.700 \mathrm{~V}$; the cause was not clear, but it did not appear to be related to the acid-transport layer (no change in IR-loss or open-circuit voltage).

After 2500 hours, the IR-free voltage was $0.695 \mathrm{~V}$, as shown in Figure 56. Subsequently, the cathode oxygen-gain began to increase, indicating electrolyte flooding of the cathode, with attendant loss of open-circuit voltage as the electrolyte-matrix became starved of acid.

The IR-loss of the above cell was $50 \mathrm{mV}$ at $161 \mathrm{~mA} / \mathrm{cm}^{2}$, no improvement over that of a typical cell with a standard acidtransport layer. Other cells of this type showed lower IR-losses, however, so that a greater degree of reproducibility was clearly required for the new configuration.

A five-cell, 10.7 inch $\times 14$ inch stack was constructed in October 1985 with an alternative acid-transport layer

configuration (See Appendix 2). Even though one cell ran well below par, the average cell voltage was $0.64 \mathrm{~V}$ at $161 \mathrm{~mA} / \mathrm{cm}^{2}$ and $191^{\circ} \mathrm{C}, \mathrm{H}_{2}$-air. The stack open-circuit voltage was quite high at $4.53 \mathrm{~V}$. The average cell IR-loss was about $40 \mathrm{mV}$ at $161 \mathrm{~mA} / \mathrm{cm}^{2}$.

After 2300 hours, two of the five cells showed significant performance loss, while the remaining three held essertially steady to this point (see Figure 57).

These results suggested that the alternative acid-transport layer configuration could improve cell performance: the average cell IR-1oss was about $37 \mathrm{mV}$ at $161 \mathrm{~mA} / \mathrm{cm}^{2}$, about $15 \mathrm{mv}$ below the typical loss in stacks, while the average cell open-circuit 


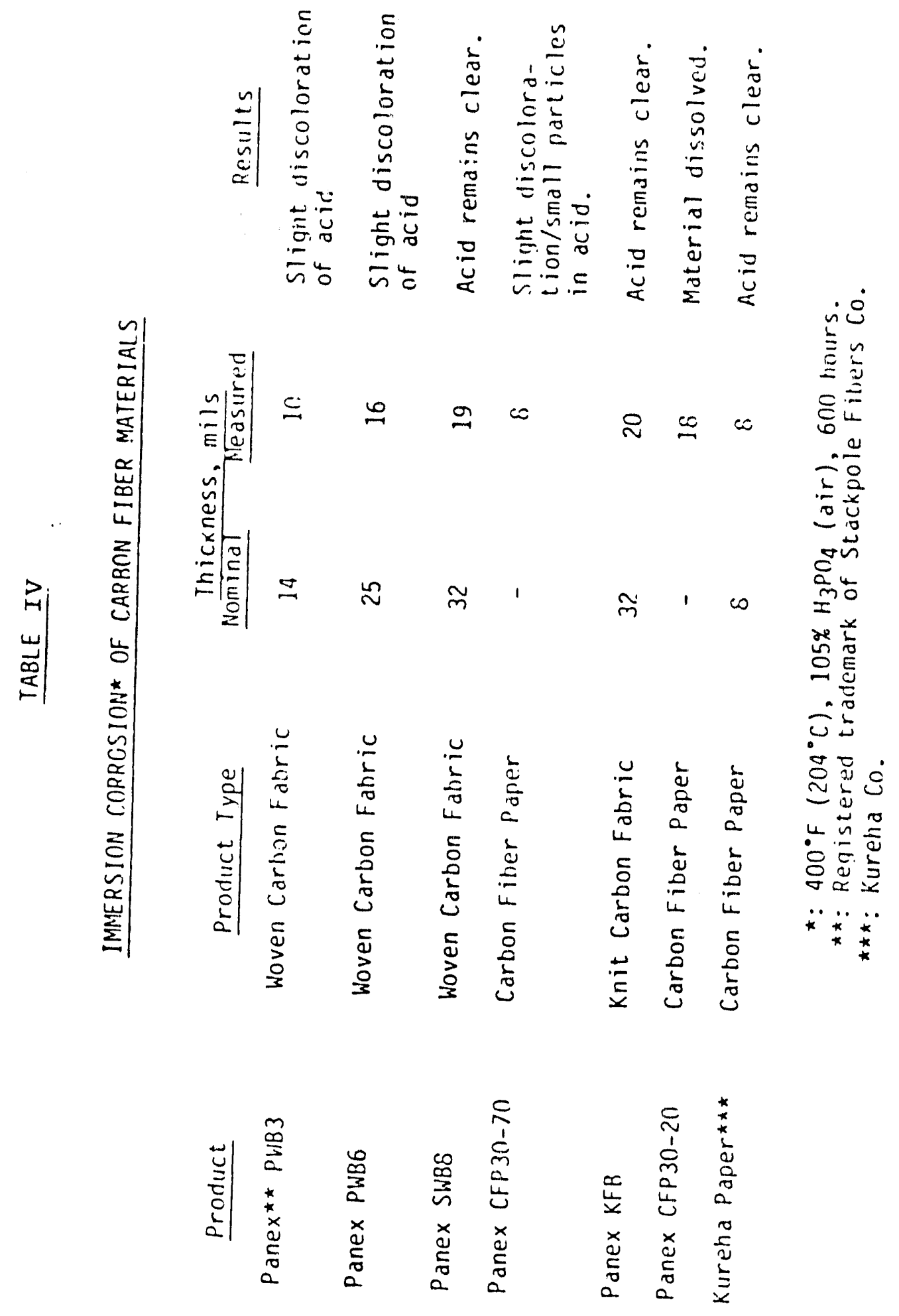




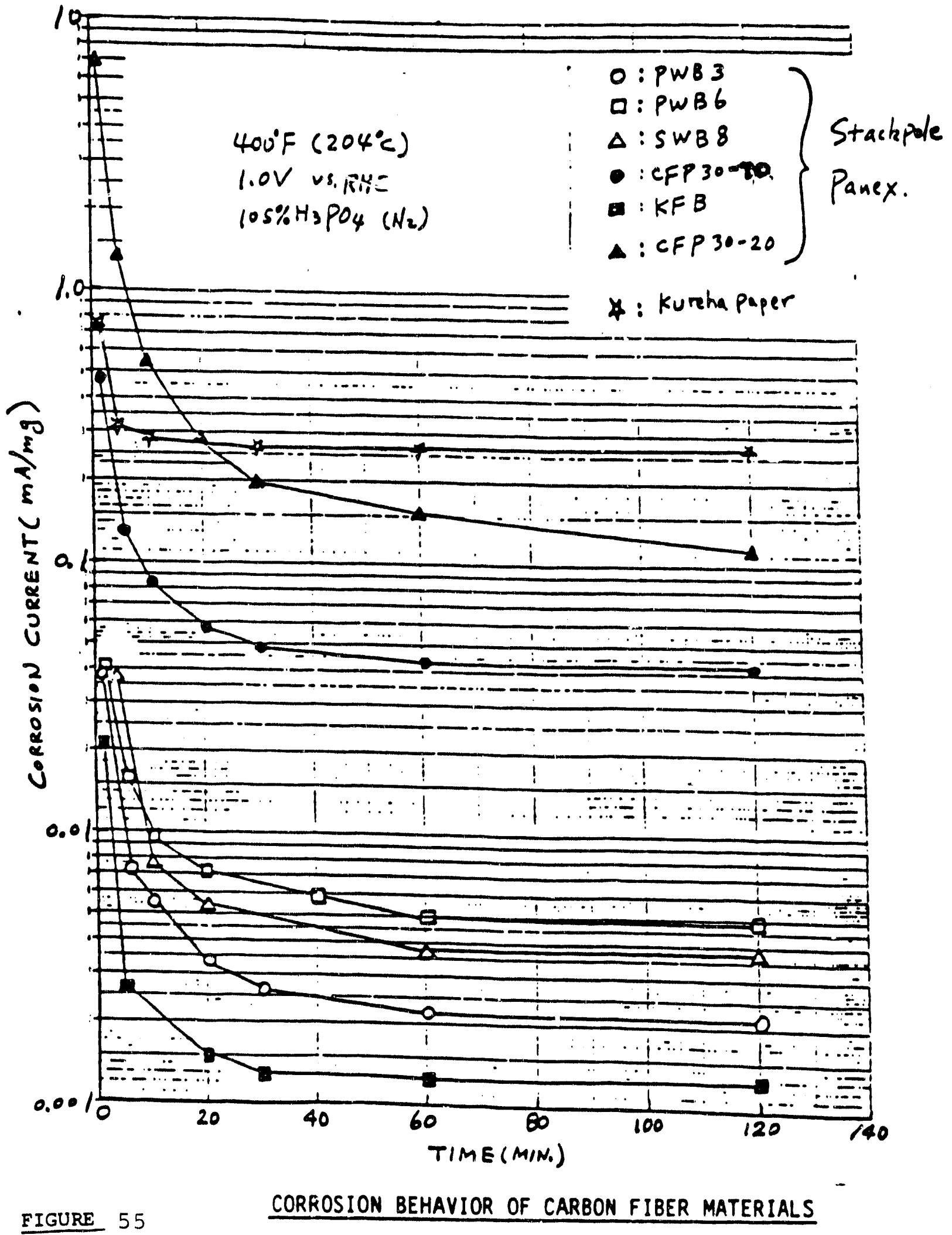



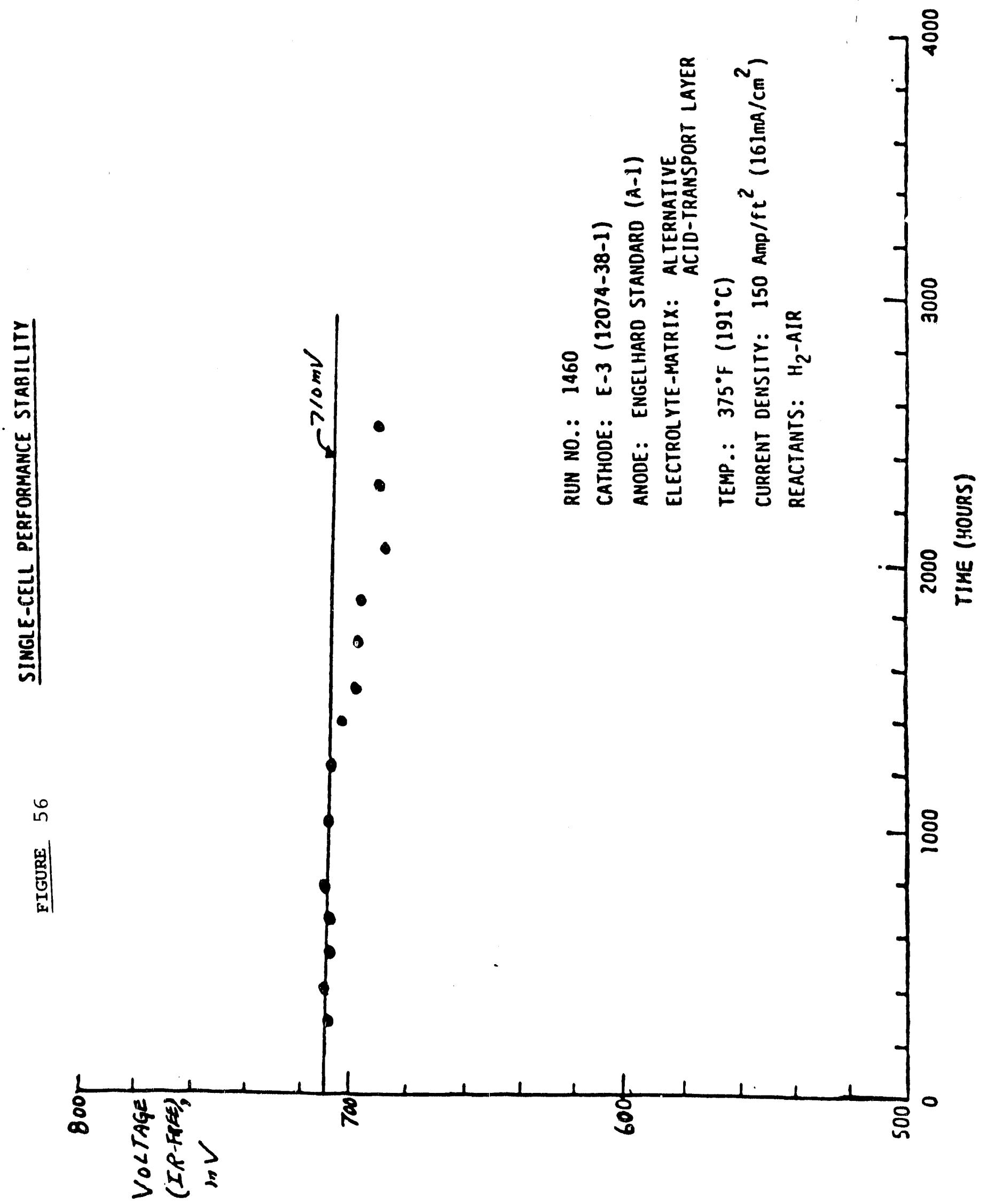


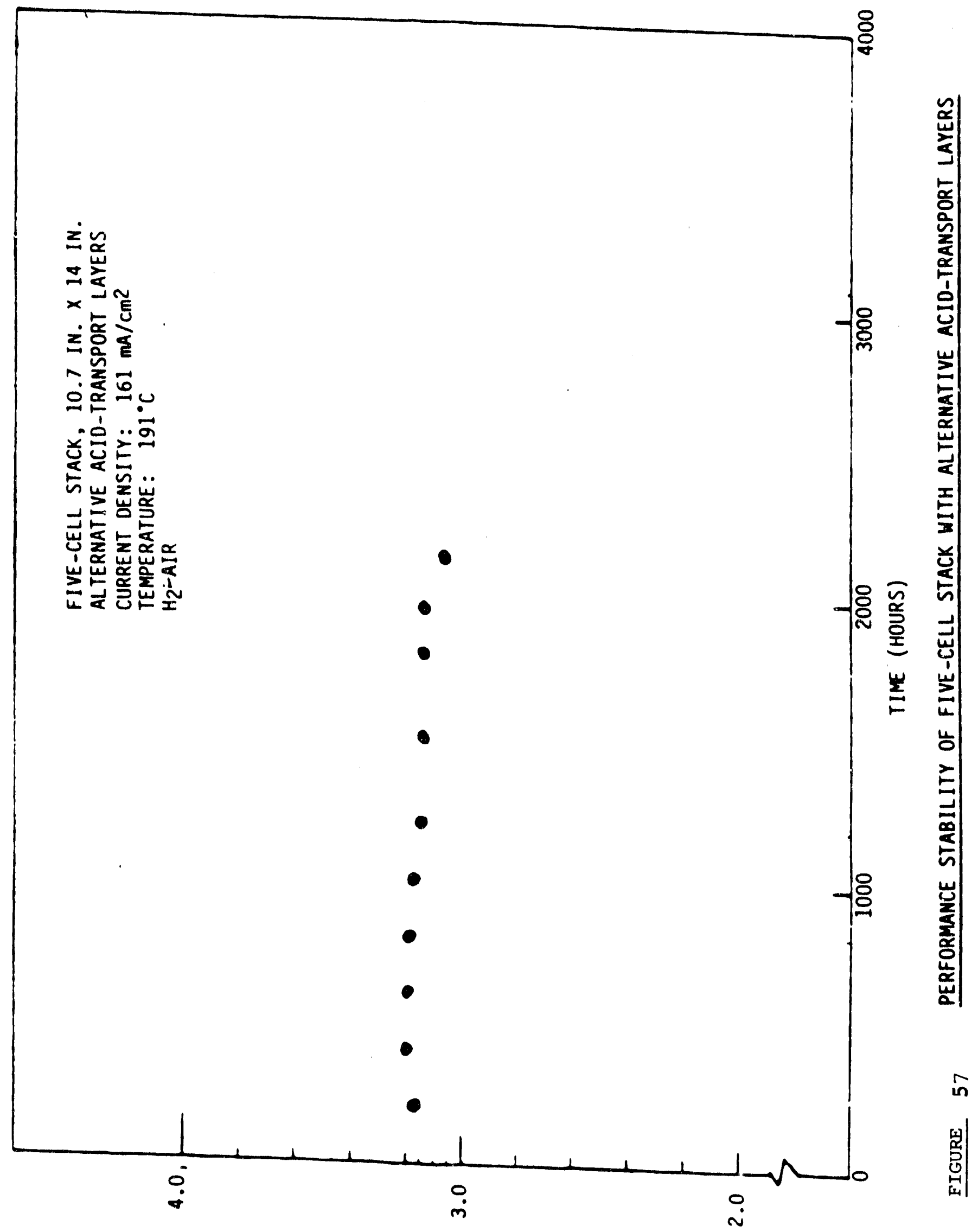

(S170A) $39 \forall 170 \Lambda 7 \forall N I W Y 3 \perp \times 3 \forall 1 S$ 
voltage exceeded $0.90 \mathrm{~V}$. However, it was also apparent that processing conditions were not yet consistent enough to yield uniform behavior.

At 4300 hours, three of the five cells had lost significant performance, while the remaining two had held steady. The performance history is shown in Figure 58, while that of the individual cells is shown in Figure 59.

The remaining two cells maintained an essentially corstant voltage for over 5000 hours on load. The stack was shut down at 5232 hours. The overall performance history is shown in Figure 60 , that of the individual cells in Figure 61.

This test showed that the alternative acid-transport layer configuration had the potential for improved cell performance. The early erratic results were corrected in the subsequerit construction and testing of $4 \mathrm{~kW}$ Stack No. 3 .

This acid-transport layer was tested in one of the six-cell substacks of $4 \mathrm{~kW}$ stack No. 3. These cells performed much better than those in other substacks, as seen in Figures 62 and 63 . In this case, the outputs of the various cells of the six-cell substack were quite similar (within a $10 \mathrm{mV}$ range), suggesting that progress had been made since the construction of the earlier fivecell stack in optimizing the process for making the alternative acid-transport layer.

Two single-cells using the type of alternative acid-transport layer intended for $25 \mathrm{~kW}$ Stack No. 2 were built and placed on test. one cell was shut down early because of unacceptable reactant gas cross-over, apparently resulting from an assembly error; the other put out $0.714 \mathrm{~V}$ IR-free at $161 \mathrm{~mA} / \mathrm{cm}^{2}$ and $191^{\circ} \mathrm{C}$ after about 1000 hours on load, down about $4 \mathrm{mV}$ from its peak. The initial performance history of both cells is shown in Figure 64 .

After 3360 hours on load, this cell put out $0.688 \mathrm{~V}$ IR-free $\left(\mathrm{H}_{2}-\mathrm{air}\right)$ at $161 \mathrm{~mA} / \mathrm{cm}^{2}$ and $1.91^{\circ} \mathrm{C}$. Because of a house power failure at 1100 hours, it dropped from a higher level after about 20 hours of hot, no-load exposure (See Figure 65). Another such sell was placed on test, putting out $0.692 \mathrm{~V}$ IR-free $\left(161 \mathrm{~mA} / \mathrm{cm}^{2}\right.$ and $\left.191^{\circ} \mathrm{C}\right)$ after about 2100 hours on load. Its performance is also shown in Figure 65. The cell was shut down in February 1987 because of the damage caused by a series of house air compressor malfunctions. It had been performing at $0.647 \mathrm{~V}$ IR-free $\left(\mathrm{H}_{2}-\mathrm{air}\right)$ at $161 \mathrm{~mA} / \mathrm{cm}^{2}$ and $191^{\circ} \mathrm{C}$ after 5330 hours on load.

The overall test results were sufficiently encouraging that this concept/material was adopted for the ensuing PAFC work. 


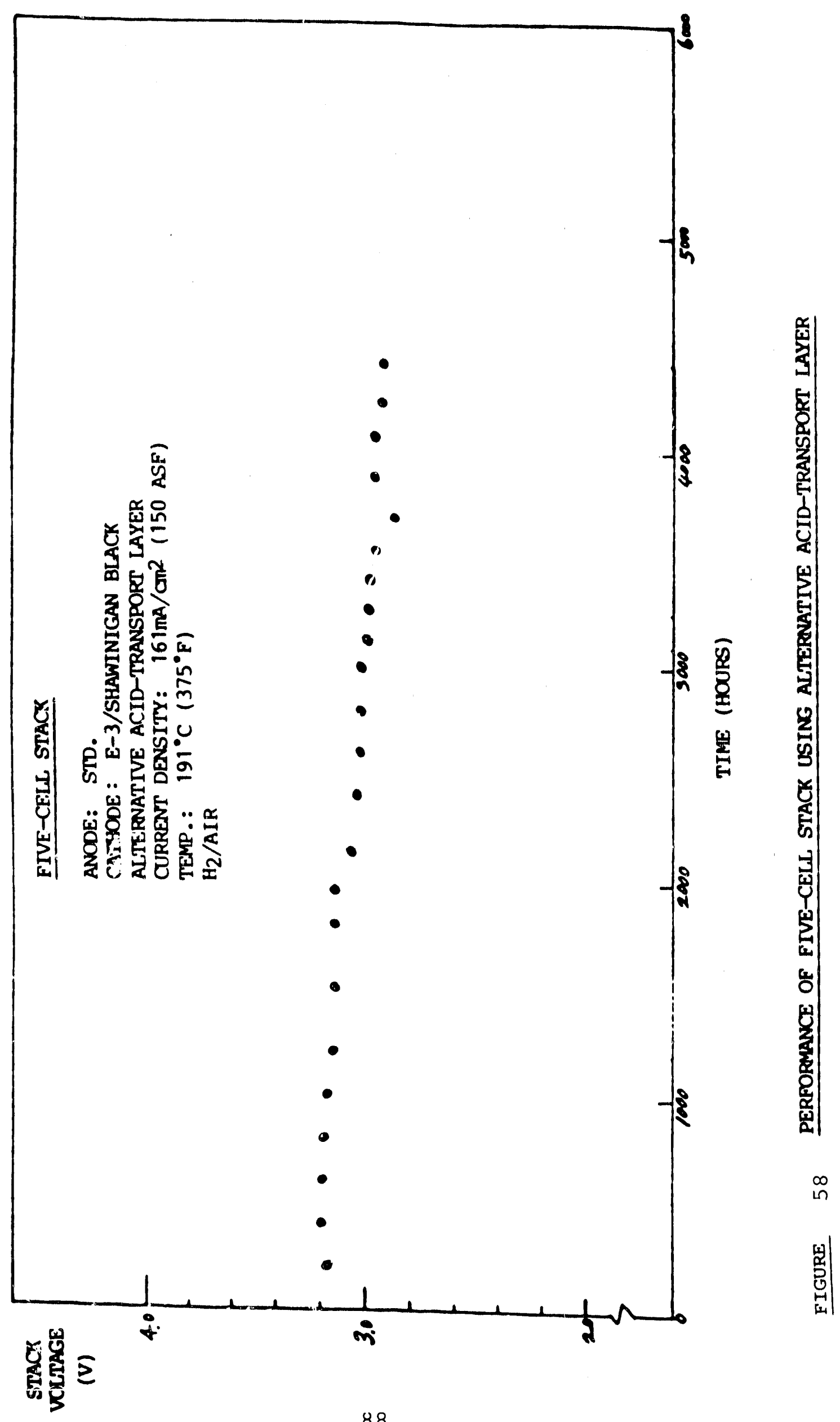




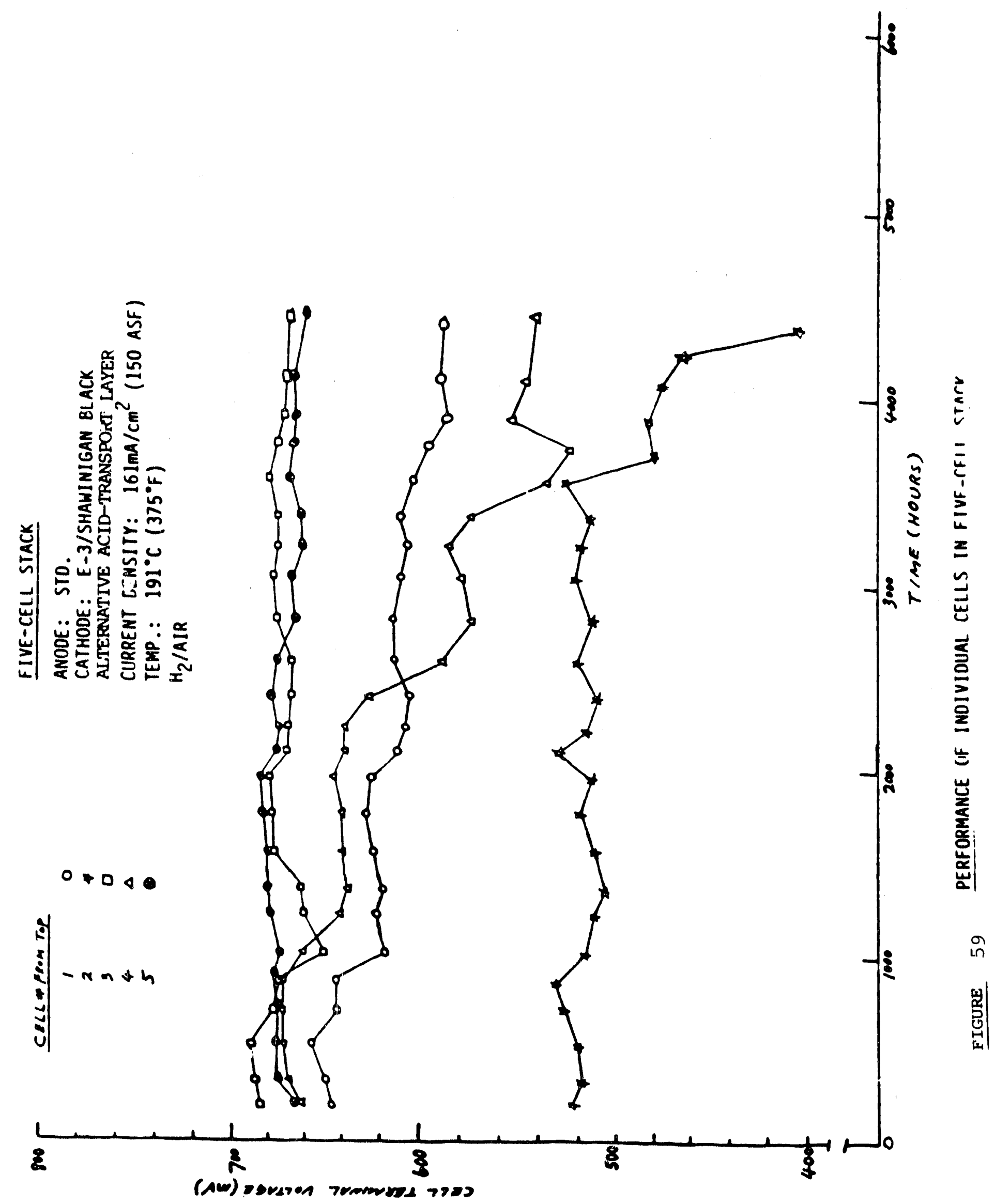




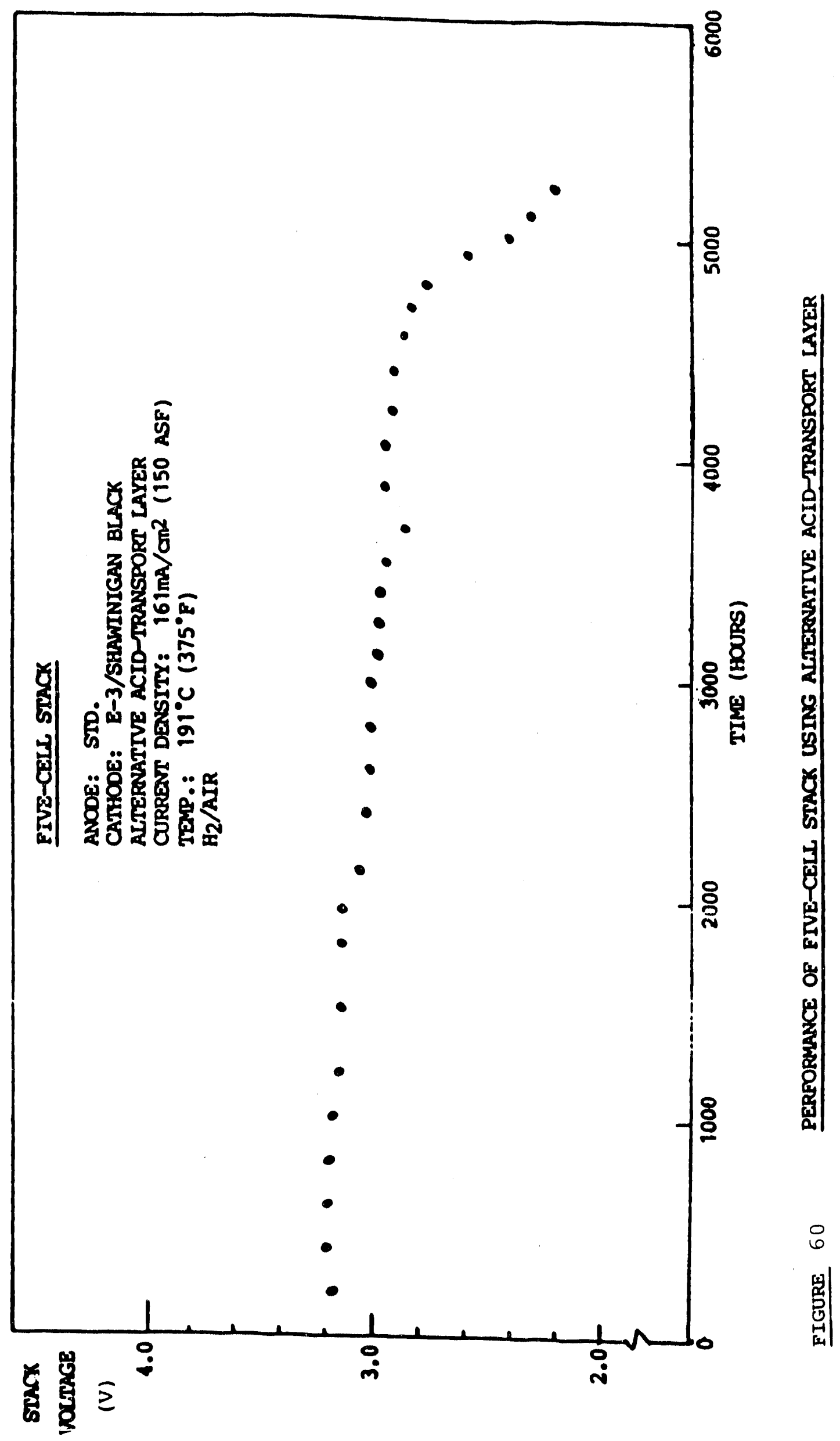




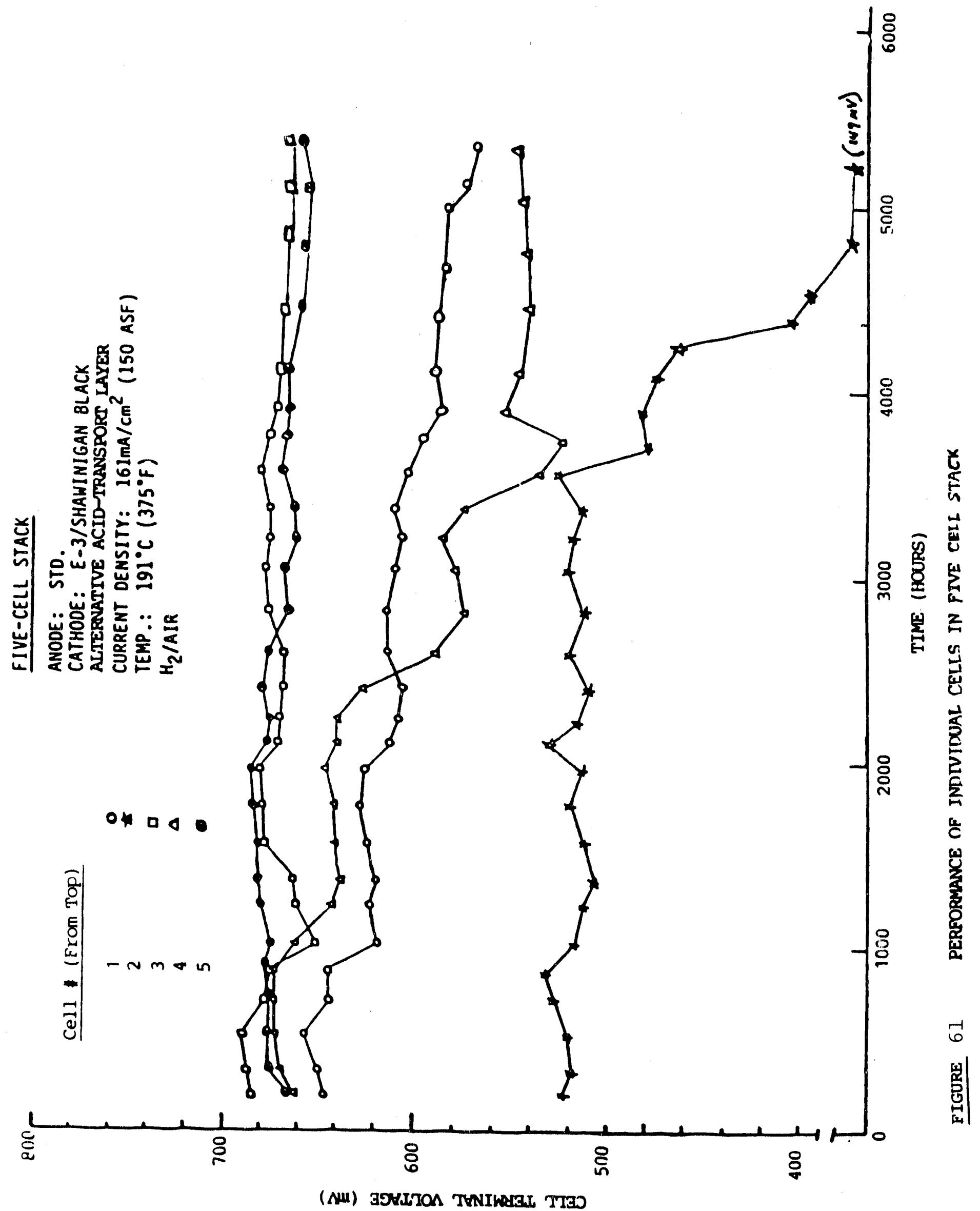




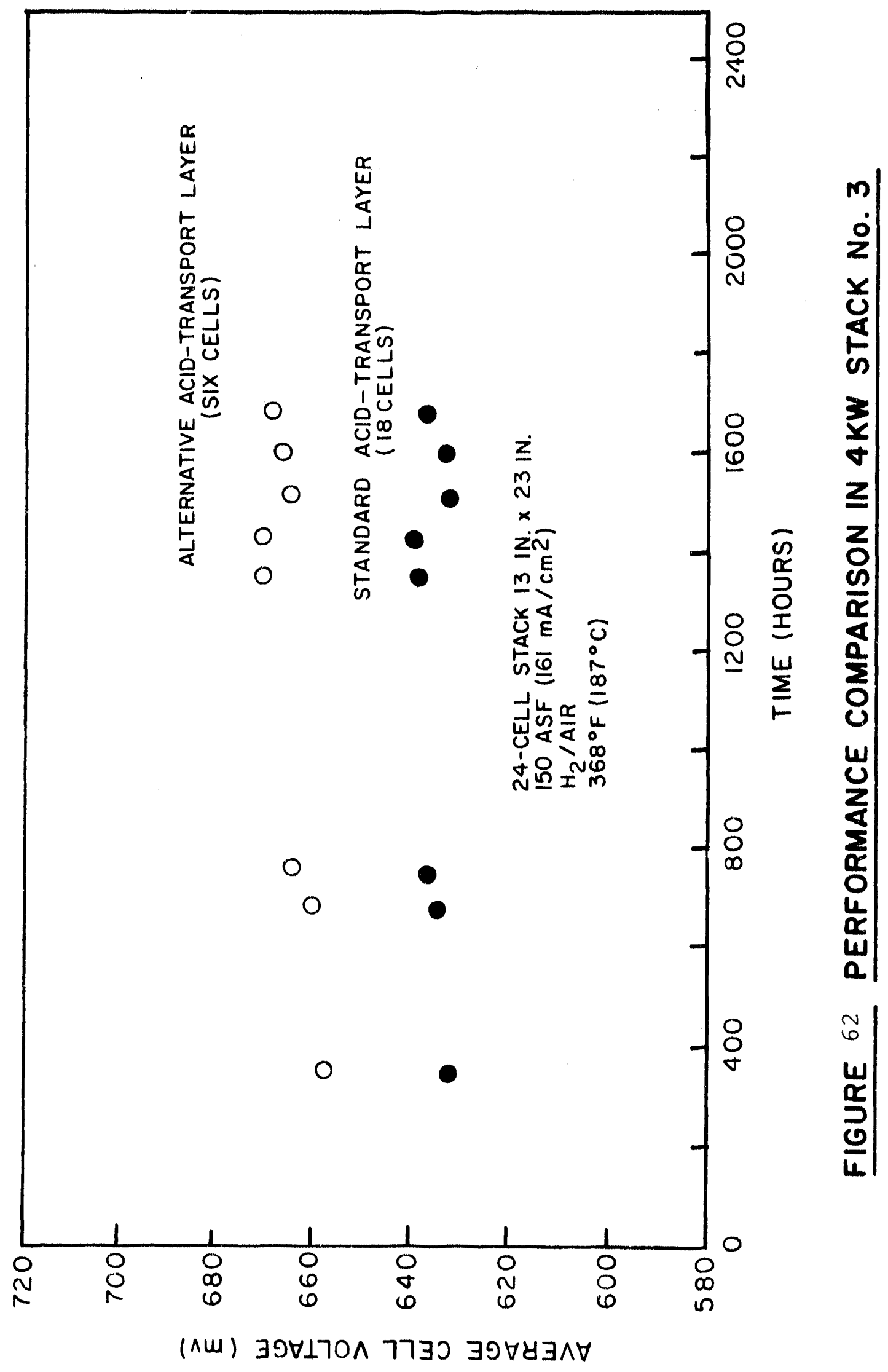




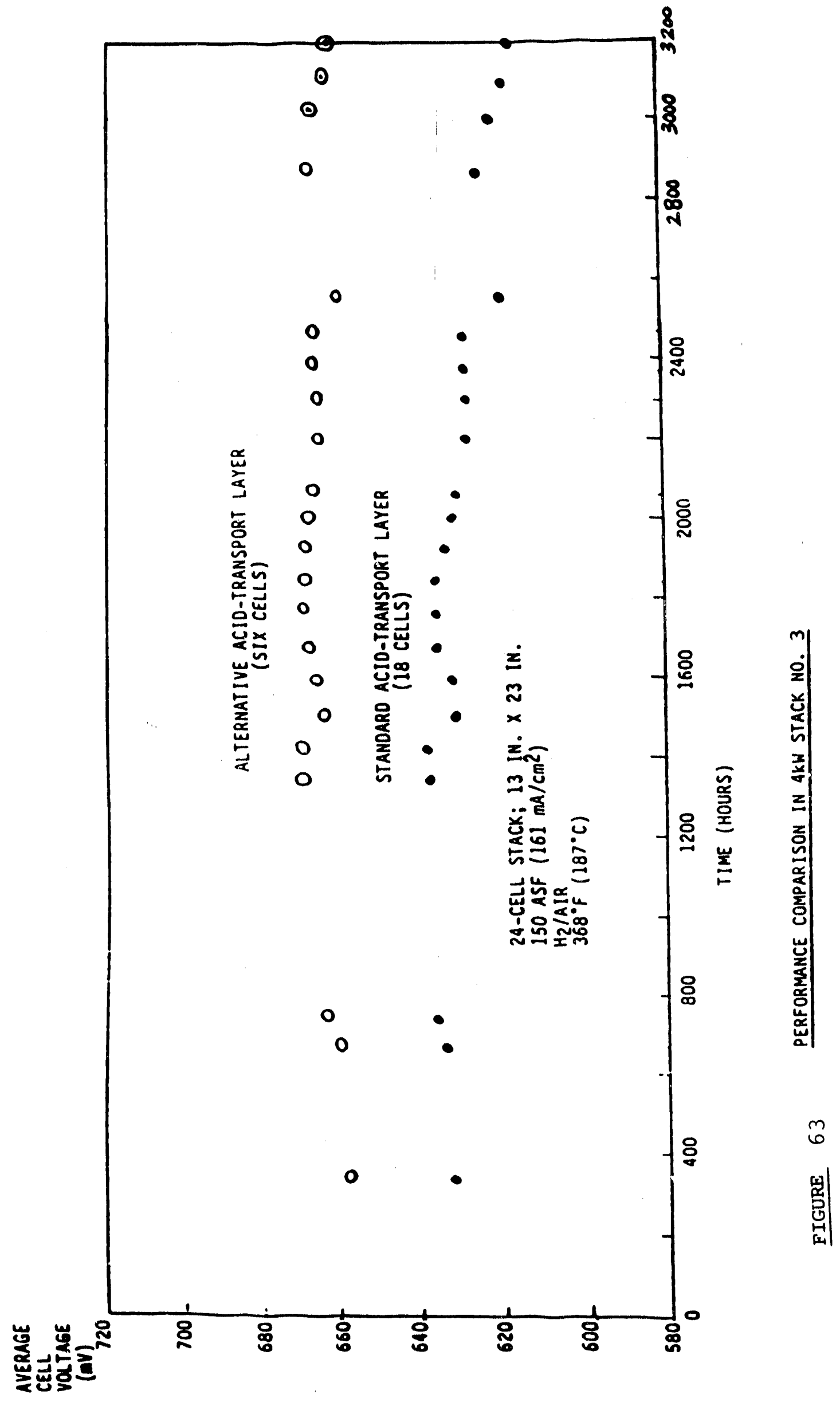




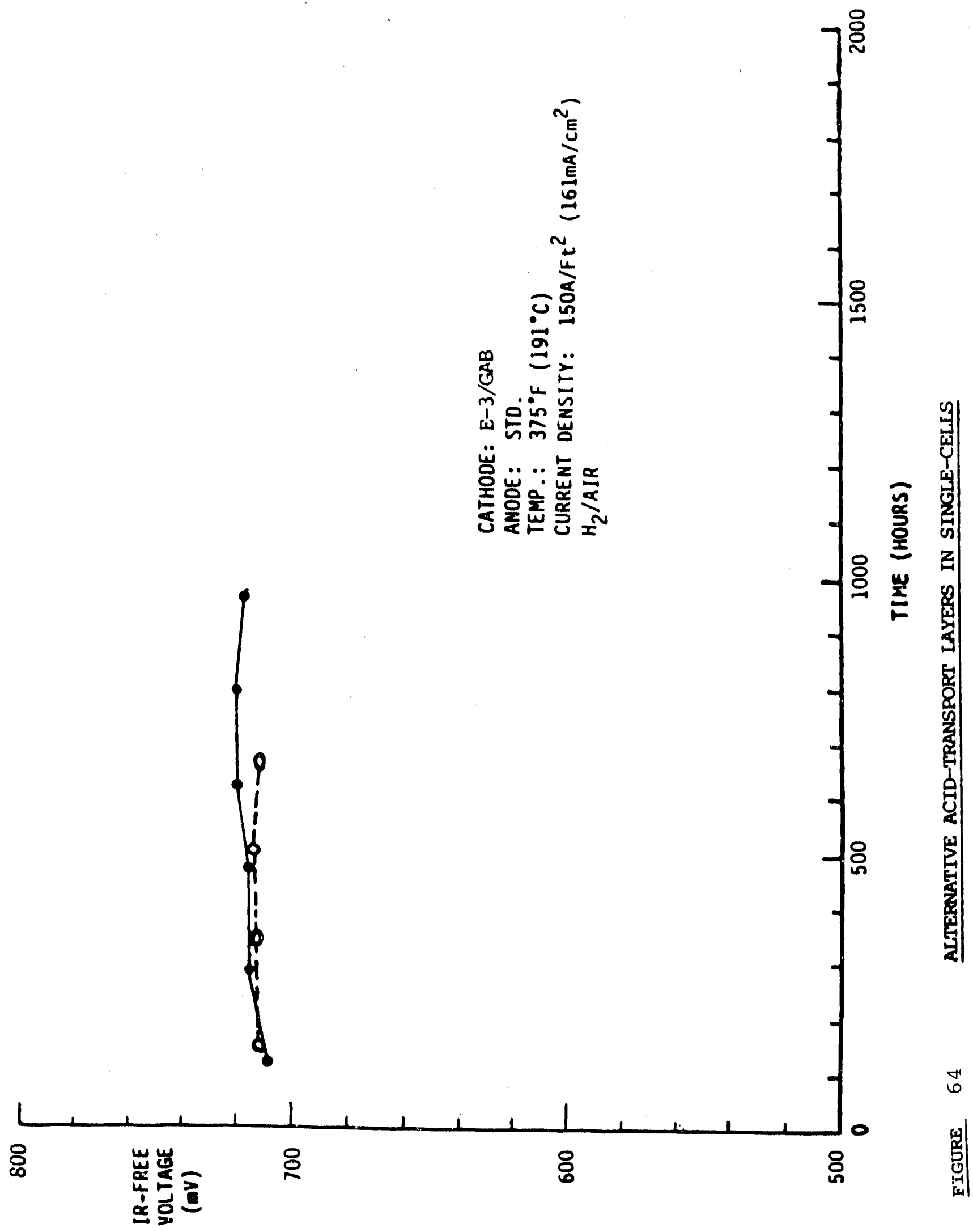




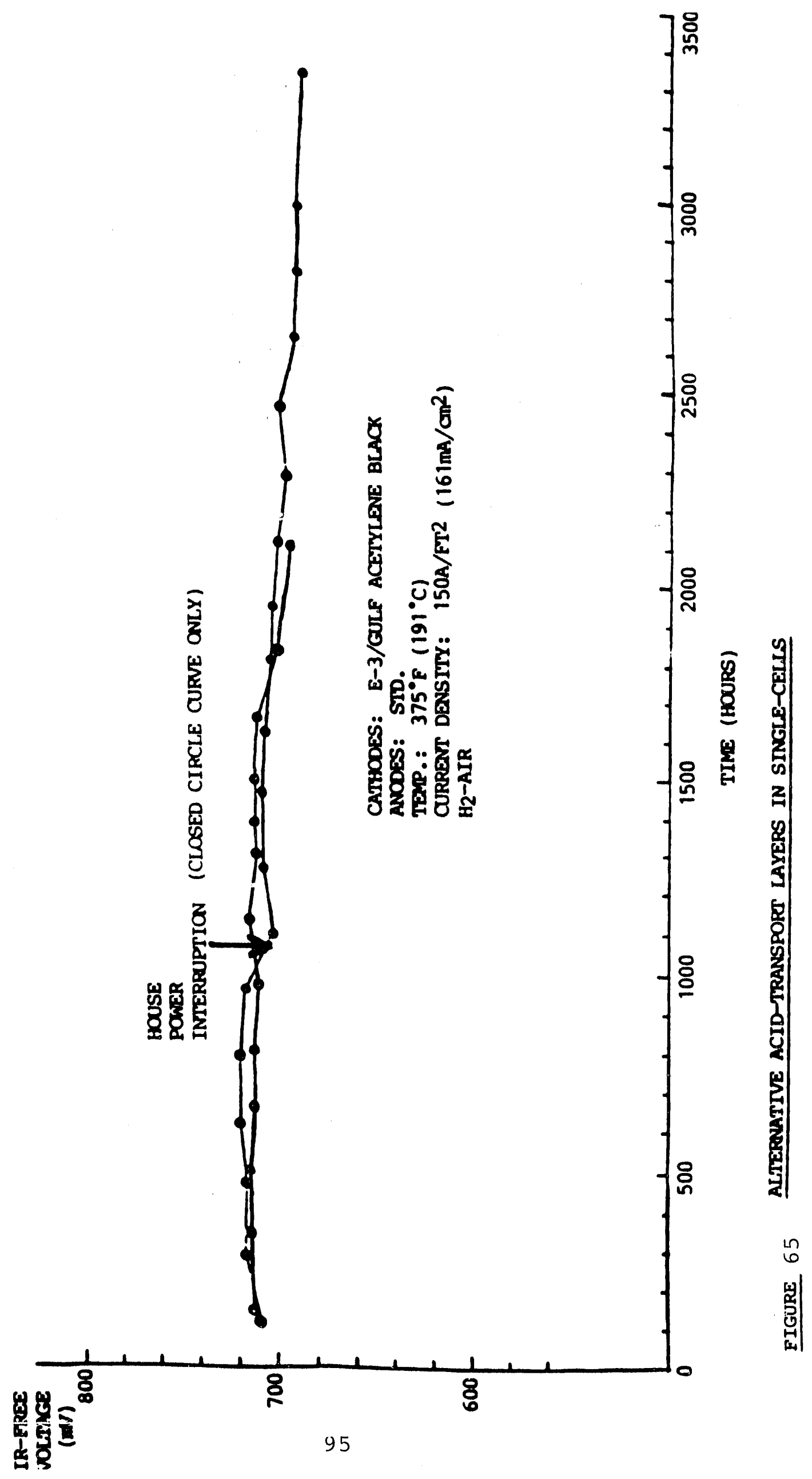




\section{Alternative Carbon Paper}

Single cells were tested to evaluate new carbon paper electrode substrate materials from both Toray and Great Lakes; these were replacement candidates for the stackpole material (PC206), which was no longer available from stackpole.

A cell in which Toray paper was evaluated showed good stability through the first 3300 hours; but it decayed rapidly during November 1987 , losing $36 \mathrm{mV}$ at $161 \mathrm{~mA} / \mathrm{cm}^{2}$ (to $0.665 \mathrm{~V}$ IRfree); this is shown in Figure 66. It was shut down at the end of November (after 4000 hours on load) because of a heating pad failure.

Several processing variations for the Great Lakes paper were evaluated in single-cell tests. They involved both fluoropolymer loading and sintering temperature. One cell in which this paper was used in both cathode and anode showed stable performance and appeared to be recovering well from a power-failure/fuel-loss incident after about 3300 hours of operation. Figure 67 illustrates the results after over 6000 hours. Although somewhat less attractive than the stackpole paper in terms of its handlability, the test results showed that its performance was undistinguishable from stackpole PC206.

A second cell made with this paper started similarly well; however, it had to be shut down in early Derember because of an electrical failure in the single-cell fixture. Its 1200-hour performance history is shown in Figure 68 .

\section{B. COST REDUCTION}

\section{Larger Substacks Between Cooling Plates}

The use of five cells per cooling plate instead of four in 1983 stacks No. 1,2 and 3 produced satisfactory thermal profiles. Consequently, subsequent stacks were made with at least $20 \%$ fewer cooling plates. Still later, the number of cells per cooling plate was increased to 6 , for a total reduction of $33 \%$ in the number of cooling plates.

\section{Non-Metallic Cooling Plates}

The concept of the non-metallic cooling plates is described in Appendix 6.

A simpler way to connect the cooling tubes to the coolant manifold, using Swagelok fittings with Teflon ferrules and a direct connection without a viton gasket between the tubes and the fittings, was included in the $25 \mathrm{~kW}$ stack. 


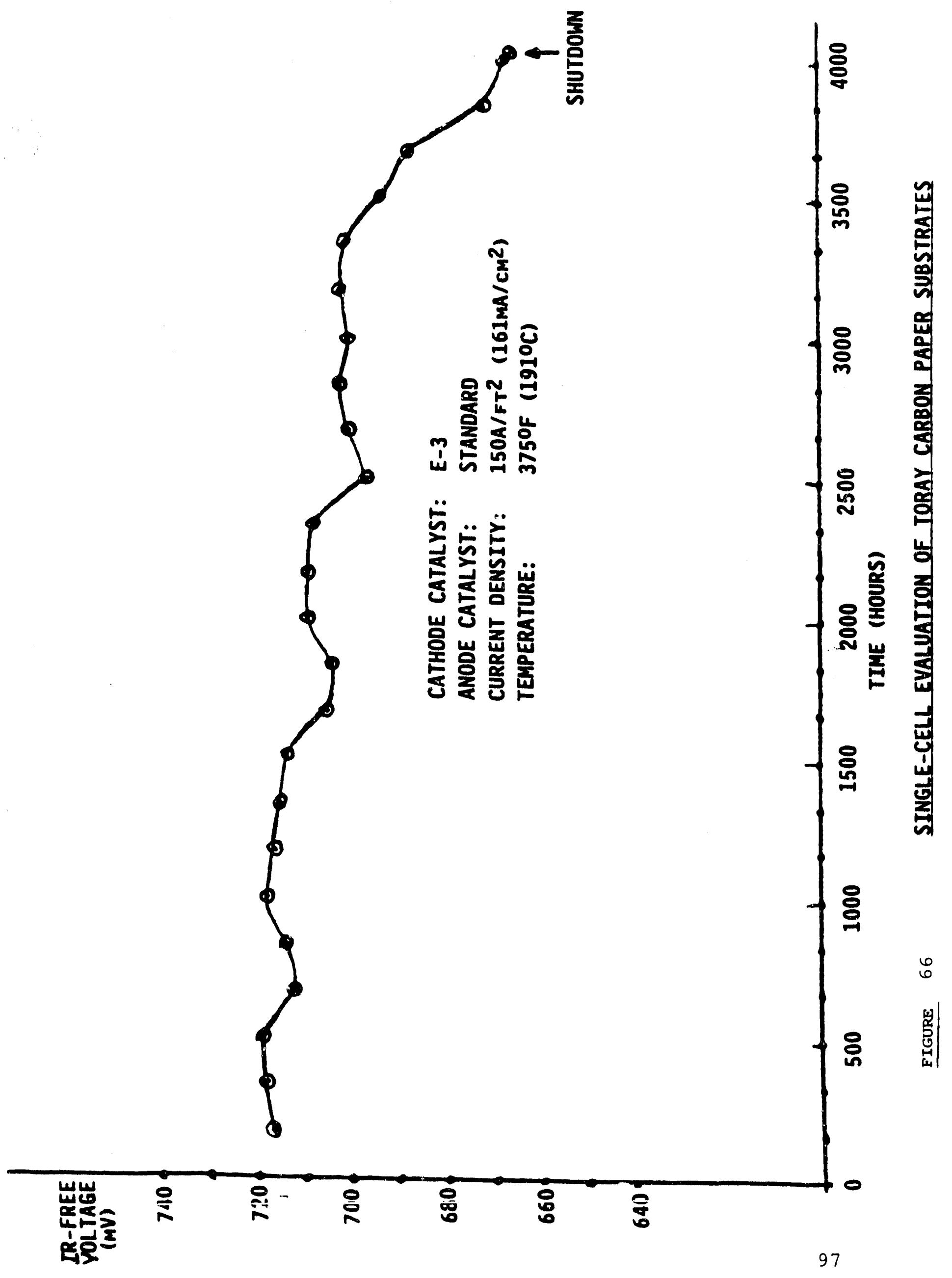




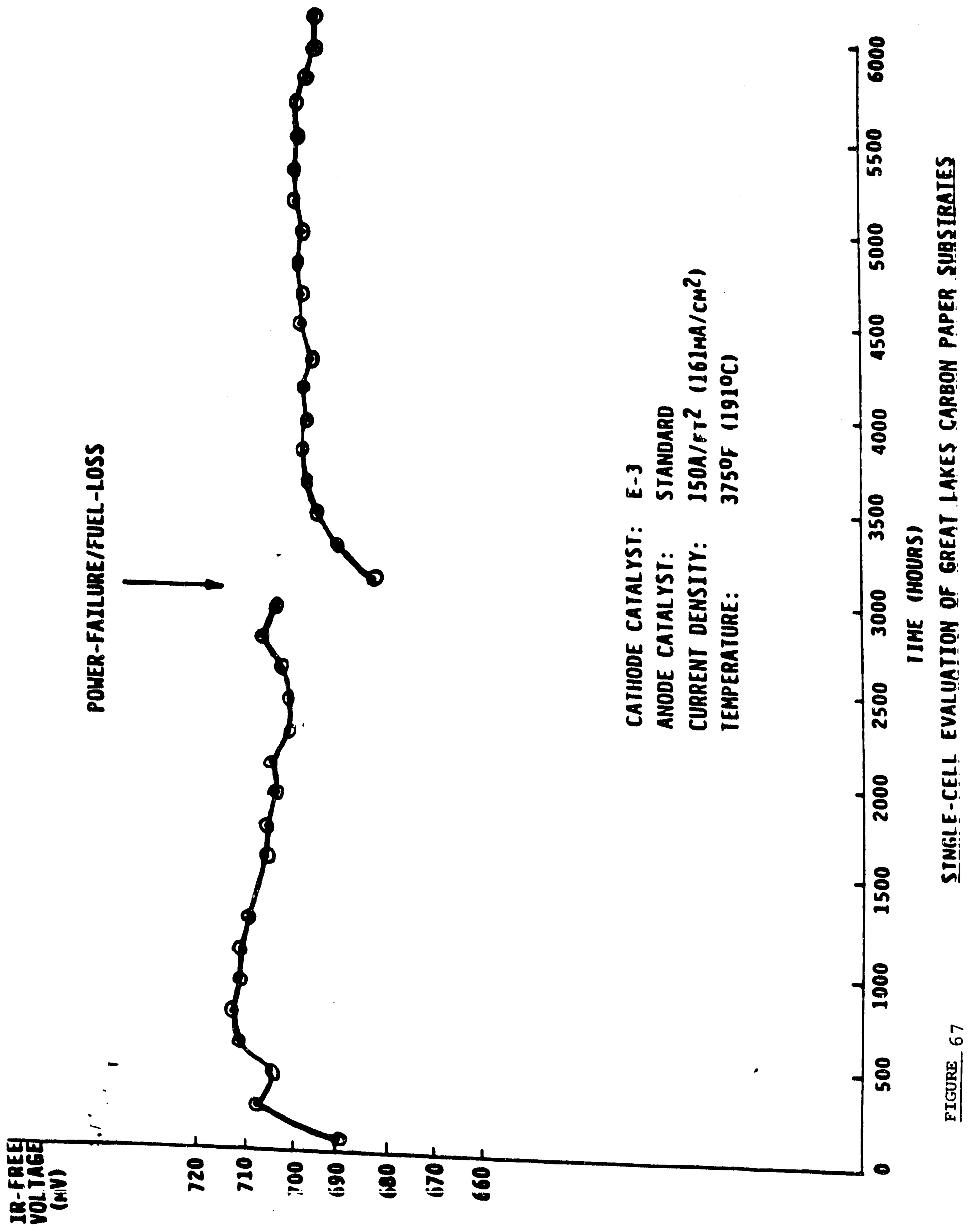




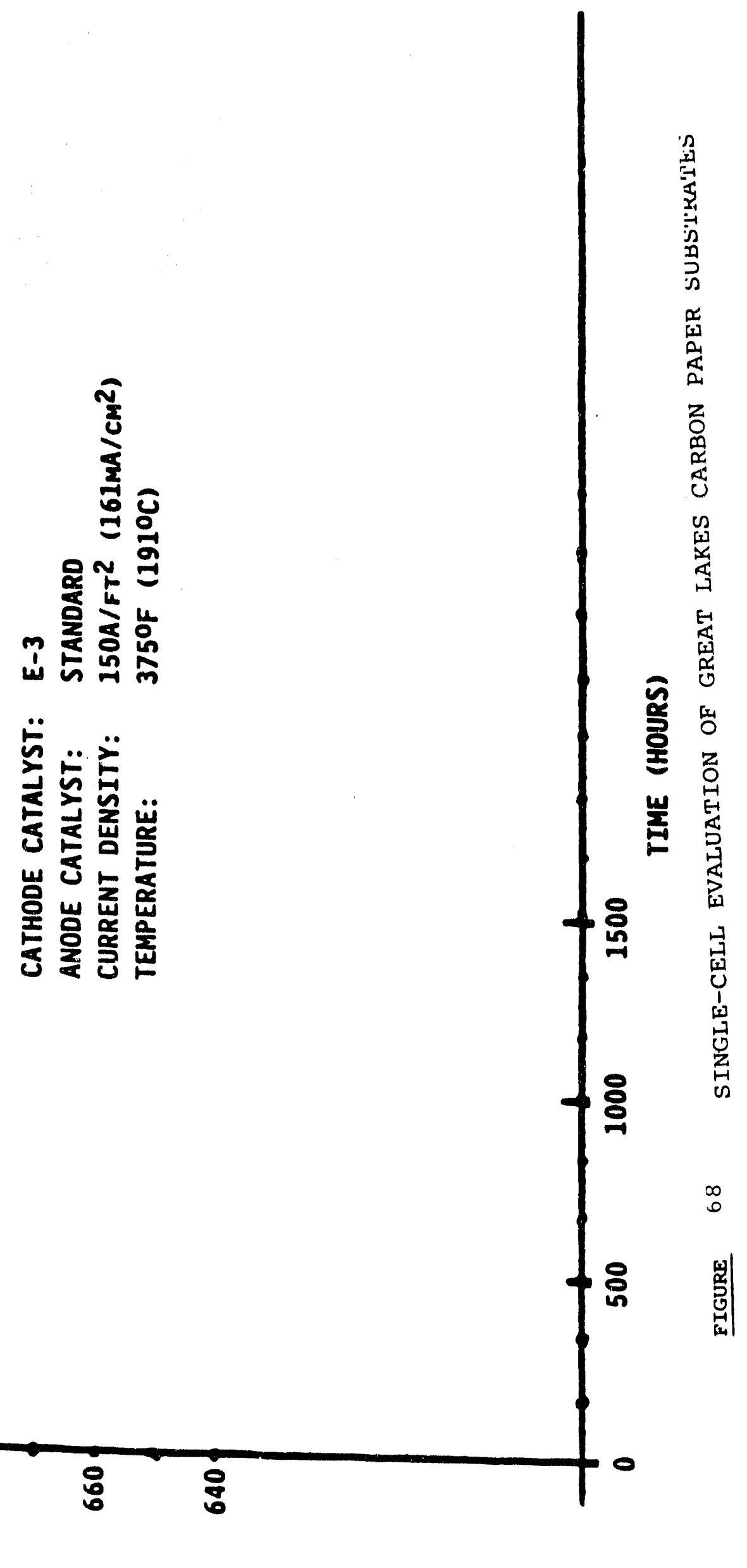


To cut back on the number of end-connections, design work and experiments were conducted with larger diameter cooling tubes than those used on pre-1985 stacks. Among the results (see Table V) was the elimination of two out of four end-connections. This came about through the use of a single tube array instead of two tube arrays, since the $\angle \triangle P$ in a single length of the larger tube is smaller than that of two paraliel lengths of smaller tubing. Performance and reliability tests of the tubes and their endconnections at $200^{\circ} \mathrm{C}$ were successfully carried out to $70 \mathrm{psi}$, as was the design and fabrication of sample grooves that can accommodate the larger tubing.

\section{Current collectors}

The concept of current collectors made of base metal coated with a protective and electronically conductive carbon-polymer composite was set aside. While they have performed reasonably well, irregular flaws occurred often enough to cast doubt on the achievability of a five-year life for this component. of special concern was the fact that a corroded or delaminated current collector (at the bottom) could not be repaired or replaced without taking the entire stack apart.

A different current collector was built into the first $25 \mathrm{~kW}$ stack. One feature of the concept, a 0.0015 " gold sheet backed by a layer of Grafoil, was successfully tested in 1984 stack No. 2 . The foil prevented corrosion of the bottom current collector, as evidenced by the absence of significant interface resistance.

A more advanced current collector concept (see Appendix 7), based on the use of standard gold-clad base metal wire made at Engelhard's Plainville plant, was studied in 1985. This design is substantially cheaper than gold foil, easier to connect to the external load, and potentially as corrosion-resistant as the foil. Analysis of a design based on this type of collector showed that the cost of the recoverable gold cladding would be well under $\$ 10 / \mathrm{kW}$ in a $25 \mathrm{~kW}$ stack. Electrical tests on small graphite coupons showed an IR-drop of under 100 millivolts (out of a stack voltage of over 100 volts).

A simulated one-ft ${ }^{2}$ current-collecting plate of this type using all-copper 0.125-inch diameter wire (see Figure 69) was assembled and tested in september 1985. The voltage drop was measured to be an acceptable $38 \mathrm{mV}$ at an equivalent current density of $150 \mathrm{~A} / \mathrm{ft}^{2}$. Furthermore, the voltage drop would be significantly lower with the $8 \%$ (by weight) gold cladding, as per design.

Corrosion testing of the Engelhard-fabricated gold-clad ba.e metal wire, the basis for this less expensive current-collecting plate, showed no sign of phosphoric acid penetration through the 


\section{LARGER DIAMETER COOL ING TUBES}

CHANGING THE I.D. OF THE COOLING TUBES FROM 0.250"

TO $0.375^{\prime \prime}$ HAS THE FOLLOWING EFFECTS:

- number of end connections per cooling plate: 2 (VS. 4)

- $\triangle$ T FROM COOLANT to anjaCent CARBON ELEMENT: $11^{\circ} \mathrm{F}$ (VS. $10^{\circ} \mathrm{F}$ )

- cONLANT $\triangle P: 2.8$ PSI (VS. 3.9 PSI)

- CARBON K-ELEMENT THICKNESS: NO CHANGE ( $0.187 ")$ 


$$
\frac{D L}{6 \nu}
$$


gold cladding after ten months of immersion at $200^{\circ} \mathrm{C}$. Figure 70 and Table VI illustrate the rate of weight loss in one of these tests; extrapolation of these results showed that trouble-free service far beyond the projected stack life of five years can be expected from this design.

A current collector assembly based on this type of wire also performed well in $4 \mathrm{~kW}$ stack No. 3 .

Evaluation of these current collectors continued via testing of the $25 \mathrm{~kW}$ stack as well as one-ft2 stacks being utilized in other programs. No increase in IR-loss with time was observed at this interface.

\section{Bipolar Plates}

A method of cutting graphite plates with a kerf loss of about $0.030 "$ was demonstrated by the Glass Fab Co. in Rochester, $N$. Y. A diamond bandsaw cut graphite at the rate of about $1 / 4$ square foot per minute. A trial cut was successful. This technique, when scaled up, could greatiy reduce the material cost of the stack.

Lower cost graphite materials were evaluated for possible use in bipolar plates. A material designated "PH" supplied by the SERS Divisinn of Pechiney S.A. was tested for corrosion resistance; also, $A B A-t y p e$ bipolar plates made from this mate:ial were tested for through-plane gas leakage and electrical resistance. The corrosion tests showed $\mathrm{PH}$ to be superior to both graphite materials previously used ("HLM" from Great Lakes carbon and "940G" from Airco-Speax). Figure 71 shows the respective corrosion currents at $0.8 \mathrm{~V}$ versus RHE, while Figure 72 illustrates the corrosion current as a function of potential. A lower "Tafel" slope of the $\mathrm{PH}$ material is apparent from Figure 72 ; this indicates that the advantage of this material from a corrosion resistance standpoint is even greater at typical fuel cell operating potentials (i.e., about $0.7 \mathrm{~V}$ ).

ABA-type plates comprised of $\mathrm{PH}$ graphite bonded with PFA Teflon film showed an ohmic loss of less than $2 \mathrm{mV}$ at $161 \mathrm{~mA} / \mathrm{cm}^{2}$. Air permeability at room temperature was undetectable.

\section{IMPROVED RELIABILITY}

\section{Non-Metallic Cooling Plates}

The heat-transfer performance of the non-metallic cooling plates in 1983 stack No. 3 exceeded the goals established for this component. Under realistic operating conditions (See Figures 73 and 74), the effective temperature difference (log mean) from the 


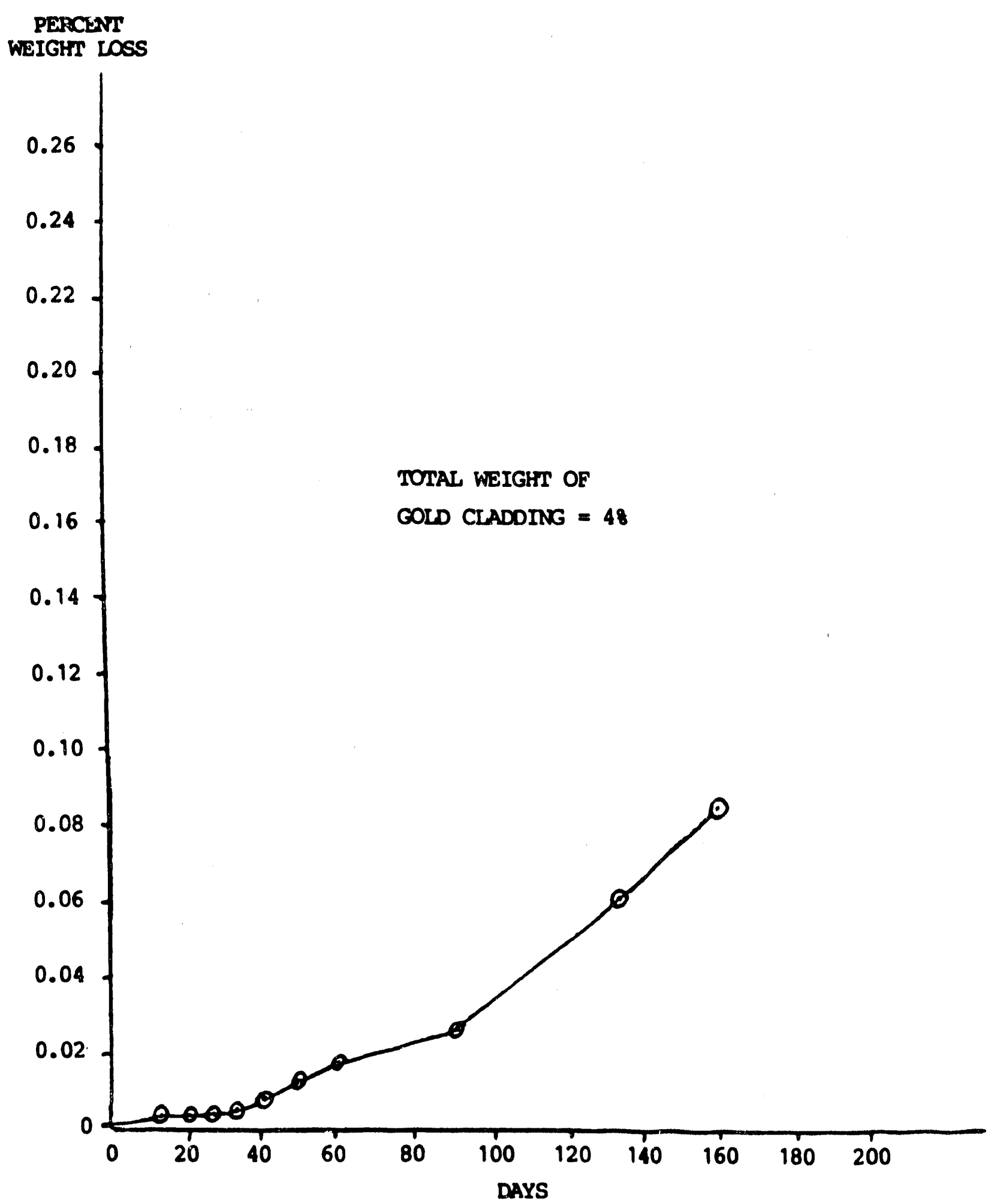

FIGURE 70 CORROSION TEST OF GOLD-CLAD WIRE 
CORROSION TESTING OF GOLD-CLAD WIRE

IN CONCENTRATED FHOSPHORIC ACID

TEMPERATURE: $200^{\circ} \mathrm{C}$

INITIAL WEIGHT: $13.4370 \mathrm{~g}$

LATEST WEIGHT: $13.3992 \mathrm{~g}$

DAYS ON TEST: 272

RATE OF LOSS: $0.37 \% / Y E A R$

LOSS IN FIVE YEARS: 1.98 


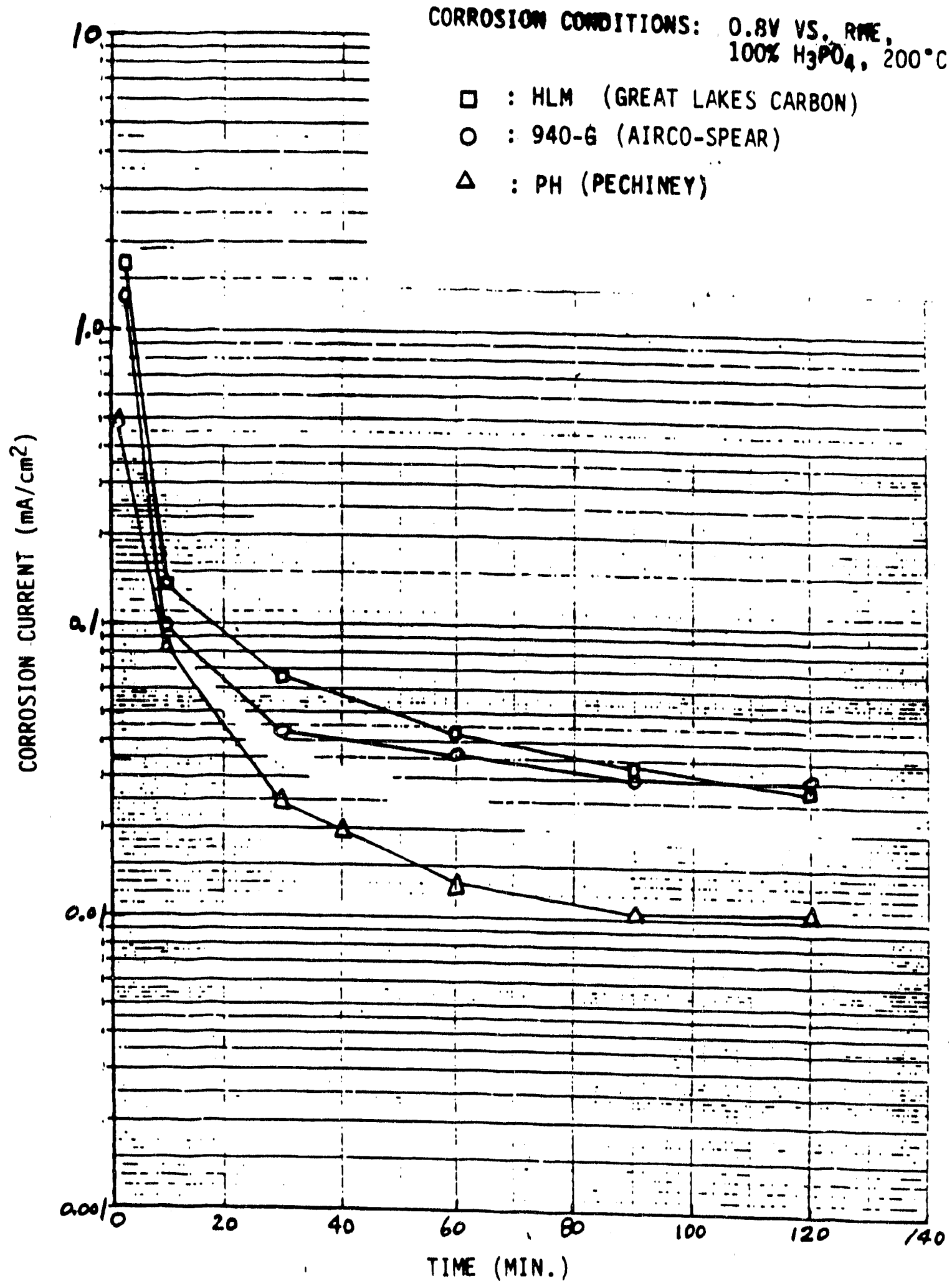

FIGURE 71 CORROSION CURRENT OF GRAPHITE PLATES 


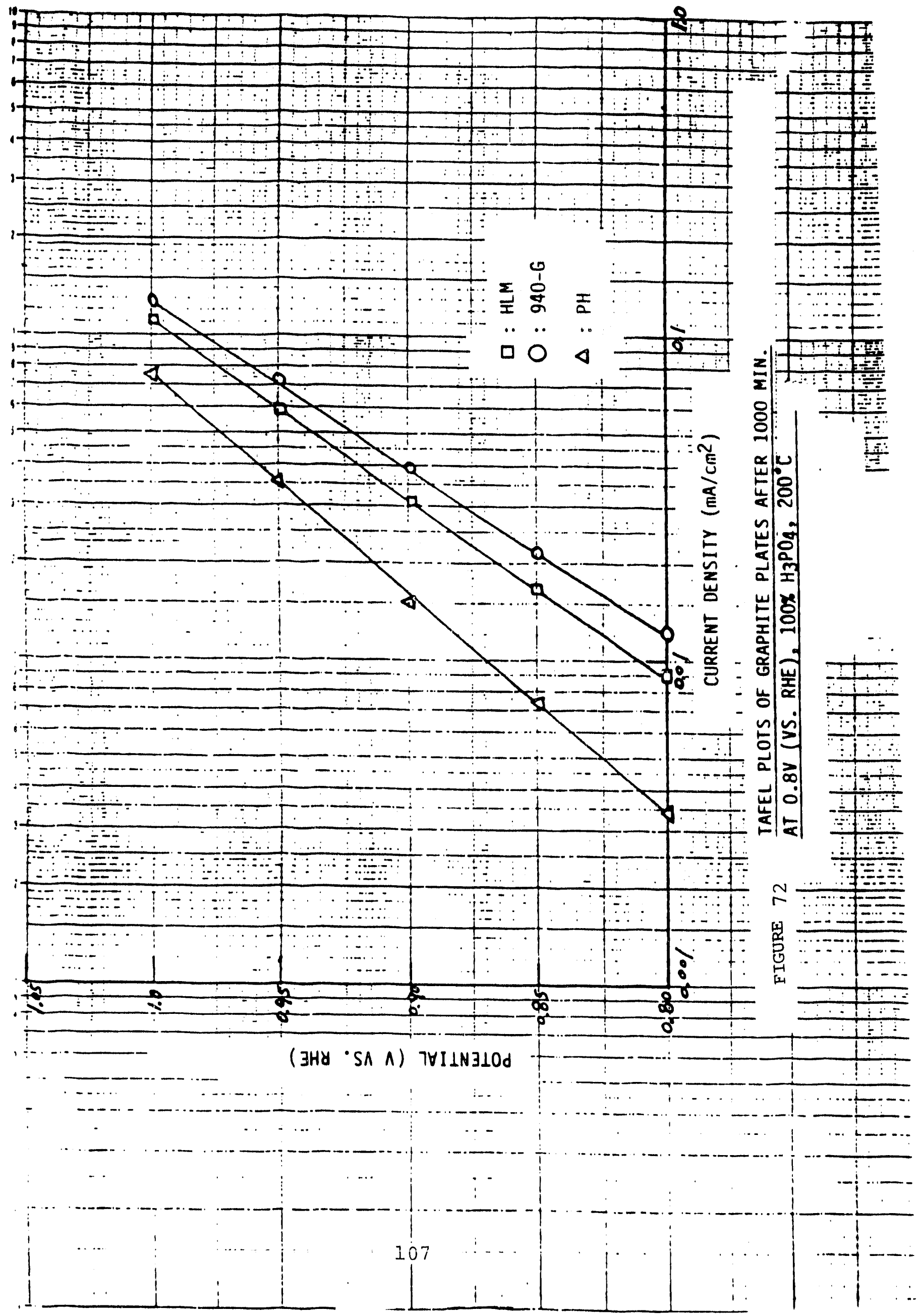




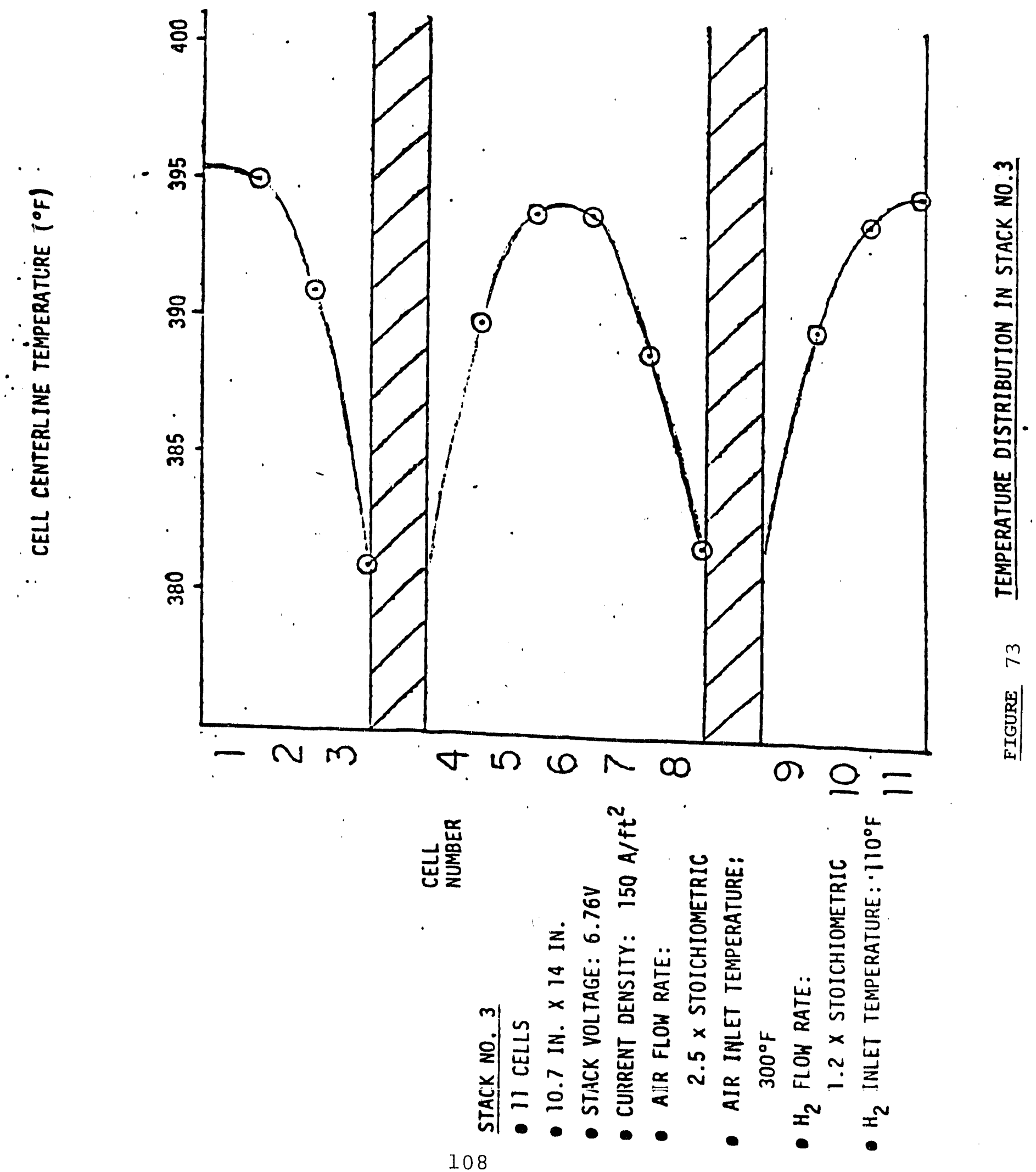




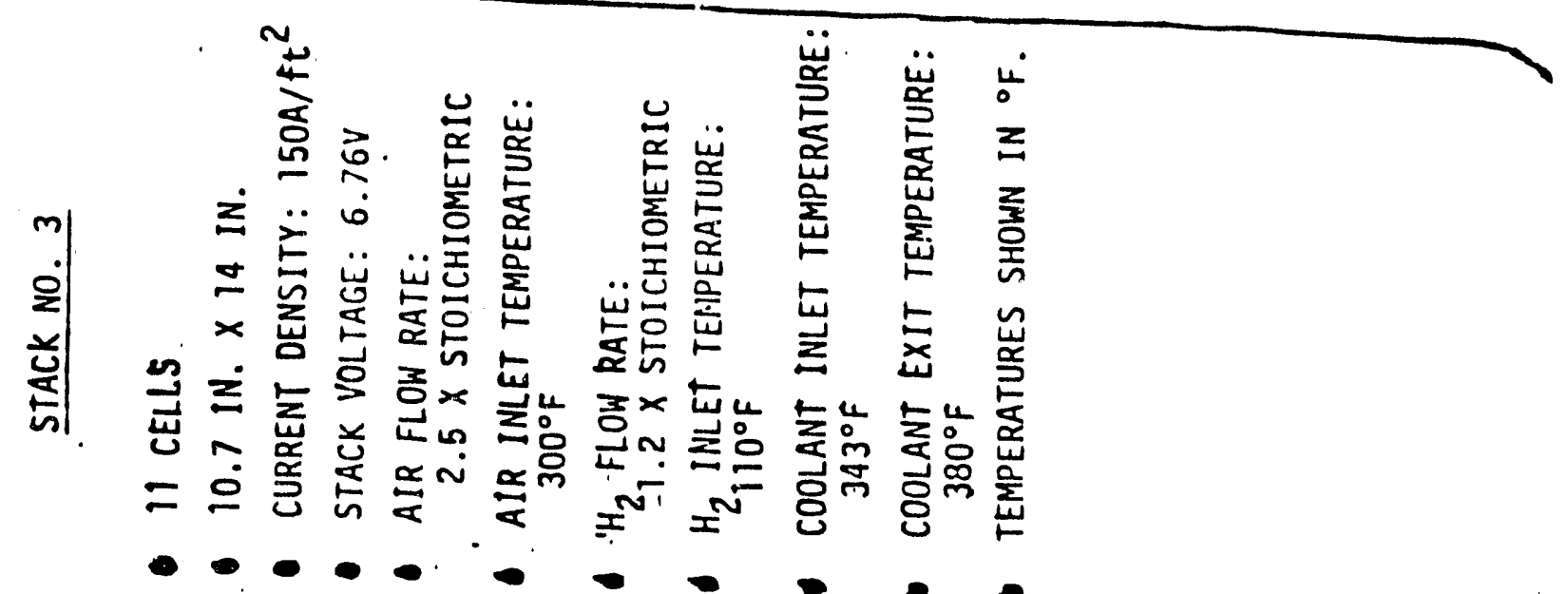

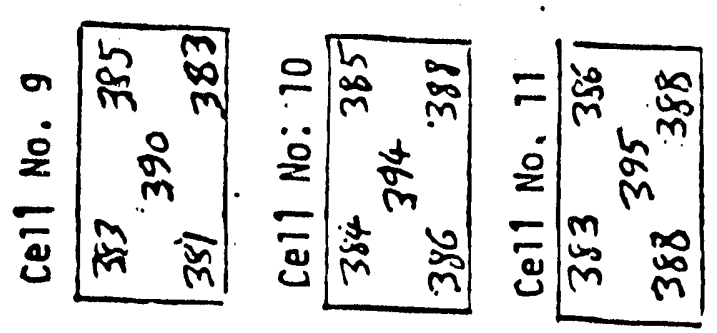

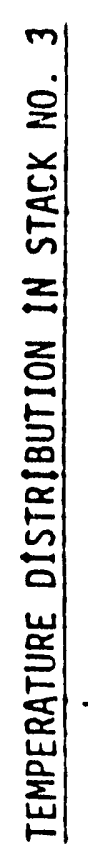

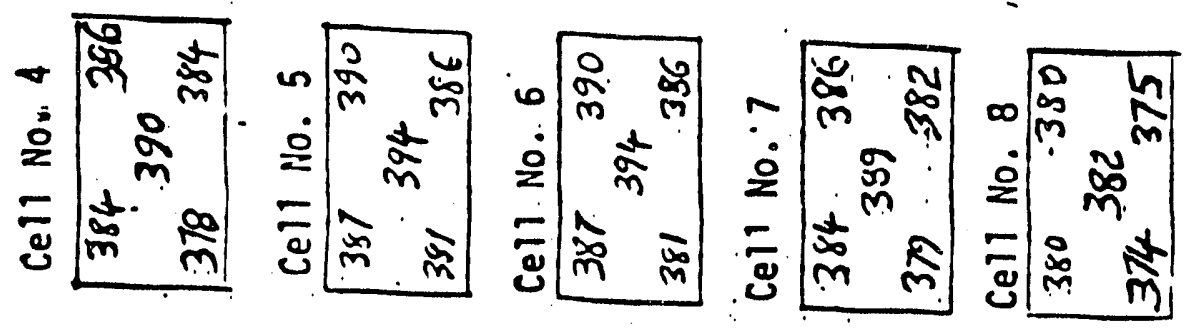

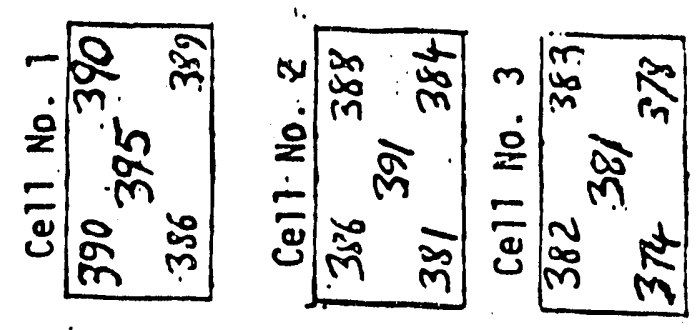


cooling fluid to the adjacent cell element was only $9.4^{\circ} \mathrm{F}$, compared to the goal of $18^{\circ} \mathrm{F}$. The corresponding overall heat transfer coefficient was $116 \mathrm{Btu} / \mathrm{hr}-\mathrm{ft} \mathrm{t}^{2}-\mathrm{OF}$. The steady-load performance history to date is shown in Figure 75 ; the vertical arrows indicate periods during which losses were sustained through hot open-circuit exposure. The non-metallic cooling plates were also successfully tested in 1984 stacks No. 1 and 2. (See Task III of this report).

\section{Bipolar Plates}

Wetproofing of $A B A$ bipolar plates requires that the fluoropolymer wetproofing be cured at elevated temperature, preferably at $550^{\circ} \mathrm{F}\left(288^{\circ} \mathrm{C}\right)$. However, the presence of the PES $B-e l e m e n t$ in the finished $A B A$ plate required a lower curing temperature to avoid a loosening of the film bond. Films of polyetheretherketone (PEEK) and PFA Teflon, unlike PES, do not soften at $288^{\circ} \mathrm{C}$. Tests to determine the suitability of these two materials as substitute B-elements were therefore carried out; they showed electrical and sealing properties as good as those of PES, provided the film-bonding temperatures were $700^{\circ} \mathrm{F}\left(370^{\circ} \mathrm{C}\right)$ for PFA and $750^{\circ} \mathrm{F}\left(400^{\circ} \mathrm{C}\right)$ for PEEK. The tests also showed that care must be taken to maintain a uniform temperature throughout the plate being bonded. Such results are enhanced through the use of a thick layer of thermal insulation around the edges.

Corrosion tests for the three candidate B-element materials were carried out as shown in Figure 76. While the corrosion currents at $0.9 \mathrm{~V}$ (versus RHE) were quite similar, the Tafel slope for PFA was far lower than those for PES and PEEK, as shown in Table VII. Therefore, the corrosion rate for PFA at typical fuel cell cathode potential (about $0.7 \mathrm{~V}$ vs. RHE) would be substantially lower.

Previous electrical testing of bipolar plates required that, to obtain reliable data on the distribution of through-plane electrical resistance ( $i . e$, across the B-element of an ABA plate), it be divided into small segments for individual testing of local areas. Testing of plates with metallic contacts covering their entire surfaces does not correctly simulate the current distribution in a stack; stack current densities are much more uniform than those generated by equipotential contacts.

A more meaningful test was devised which forces essentially equal amounts of current through each 2 inch $x 2$ inch region of any unsegmented plate, using the circuit and the physical arrangement shown in Figures 77 and 78 , respectively. Voltage probes directly contact the two surfaces across any region of the plate, yielding the desired data on local variations in $\mathrm{B}$-element resistance. The plate tester was used to retest unused plates and to analyze used plates from dismantled stacks; the tester also 

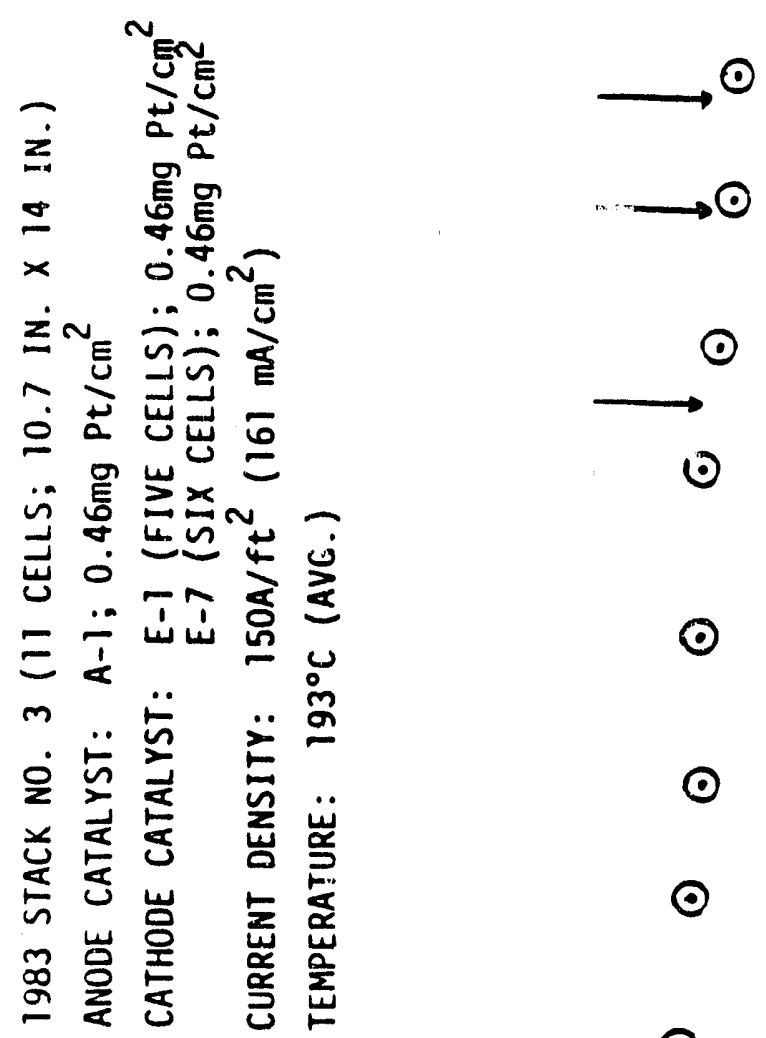

$\odot$

$\odot$

$\odot$

$\odot$

$\odot$

$\odot$

$\odot$

$\odot$

$\odot$

๑

岀

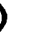

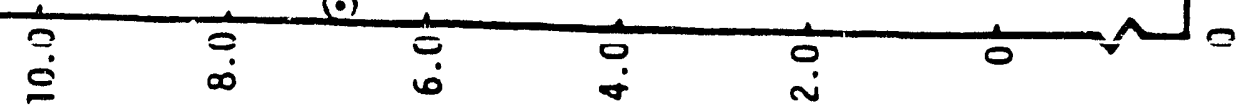




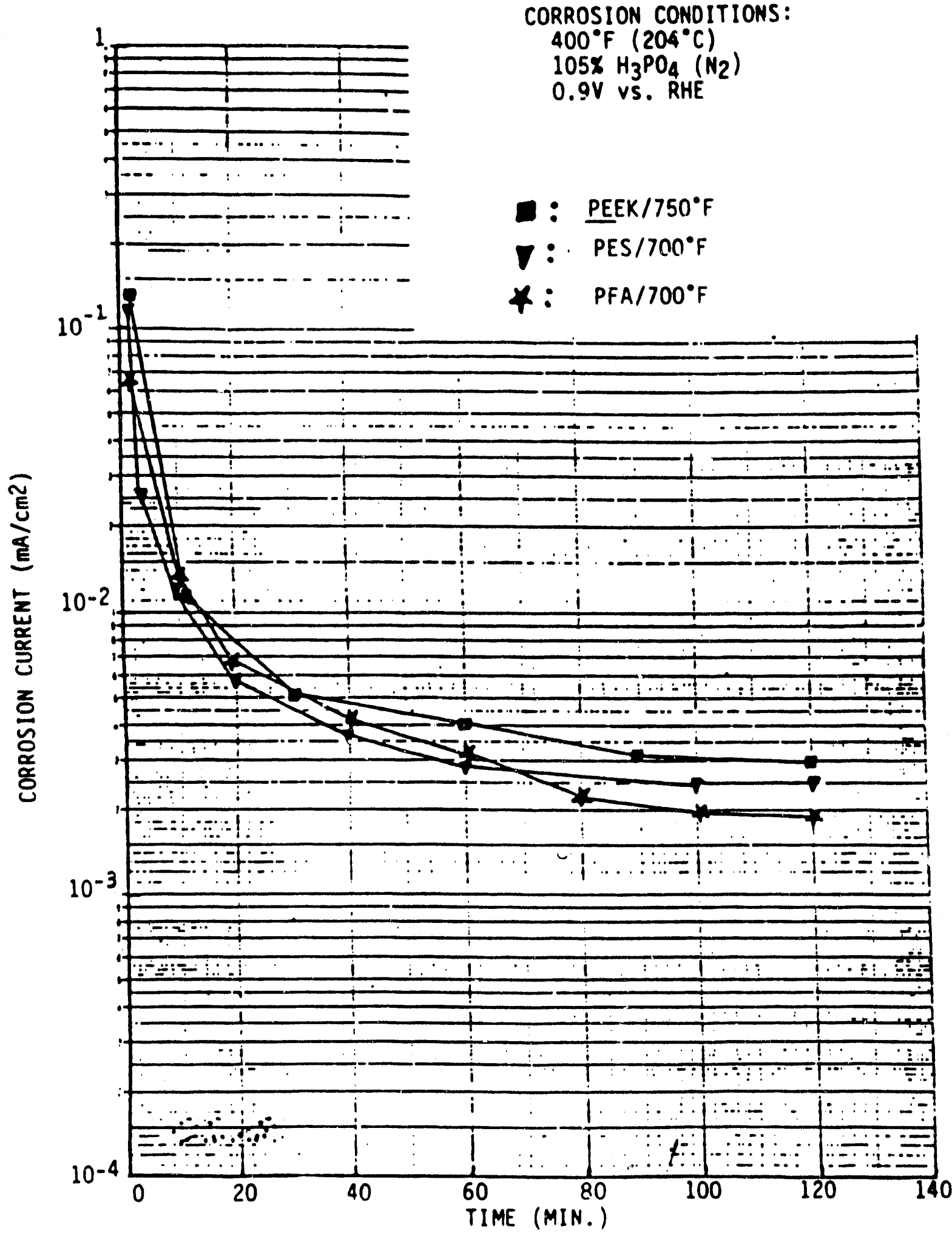

FIGURE 76 CORROSION CURRENT OF B-ELEMENTS 


\section{TABLE VII}

Tafel Slopes for Bipolar Plate B-Element Matertals after 1000-Min Test

$$
\text { Test Conditions: } \begin{aligned}
& 0.9 \mathrm{~V} \text { versus RHE } \\
& 400^{\circ} \mathrm{F}\left(204^{\circ} \mathrm{C}\right) \\
& 105 \% \mathrm{H}_{3} \mathrm{PO}_{4}\left(\mathrm{~N}_{2}\right)
\end{aligned}
$$

$\begin{array}{lc}\text { Material } & \text { Tafel Slope (mV/Decade) } \\ / 750^{\circ} \mathrm{F} & 285 \\ \text { PES } / 700^{\circ} \mathrm{F} & 275 \\ \text { PFA } / 700^{\circ} \mathrm{F} & 184\end{array}$




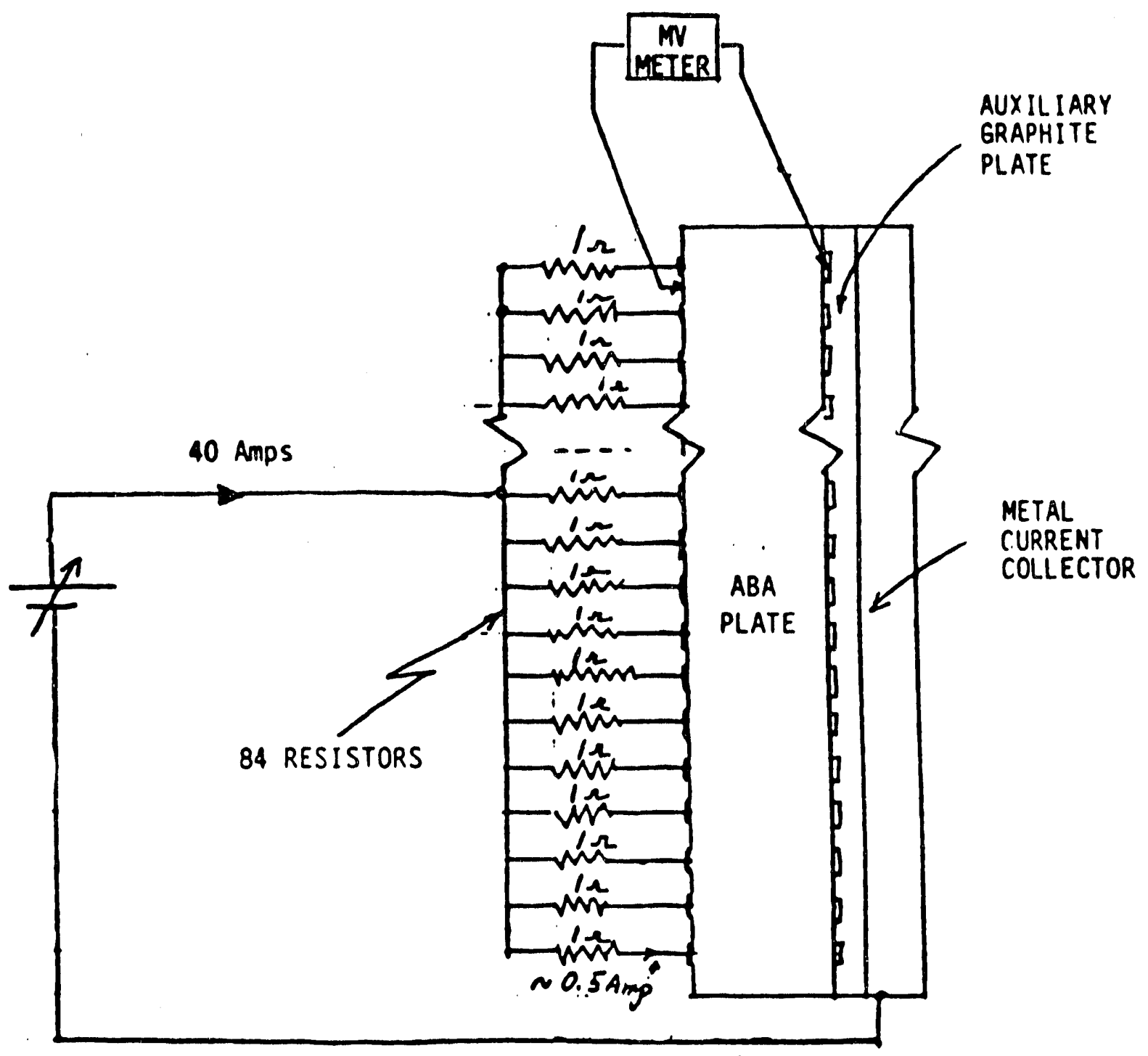

FIGURE 77 TEST CIRCUIT FOR ABA PLATES 


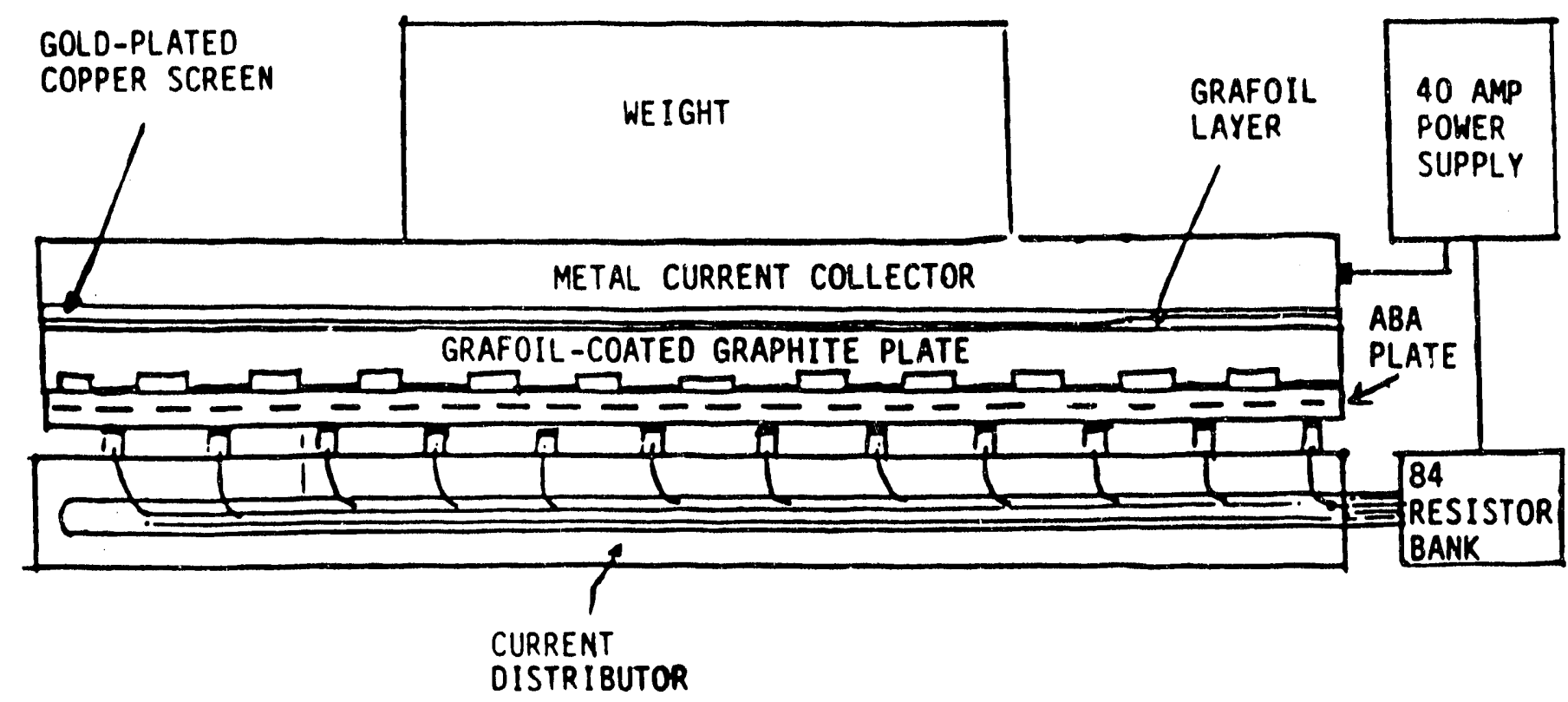

FIGURE 78 ELECTRICAL TEST FIXTURE FOR ABA PLATES 
served in production quality control. The tests showed that care must be taken to provide a uniform film-bonding temperature. Consequently, the hot-press was equipped with thermal insulation and additional heating elements to insure such uniformity.

\section{Carbon supports}

Fig. 79 shows the single-cell performance and stability of cells using an alternative type of cathode carbon support

(Shawinigan Black) and the standard cathode carbon support. The cell decay for the standard support after the first 2000 hours was $14 \mathrm{mV}$; for the altternative, more corrosion-resistant support, there was virtually no voltage decay up to 1800 hours, and the rapid decay after 1800 hours was due mainly to (1) electode flooding with a consequently high $0_{2}$-gain and (2) $\mathrm{H}_{2} / \mathrm{air}$ crossover, rather than to activation polarization losses (losses of platinum surface area or intrinsic catalyst activity). This test was ended at 3072 hours due to increasing electrode flooding and reactant gas cross-over. However, a tear-down examination showed that significant corrosion product from the single-cell aluminum blocks had accumulated under the carbon plates. This increased the stress on the carbon paper and caused it to crack, resulting in the flooding and cross-over.

Full-size electrodes (13" x 23") were also prepared using the E-3/Shawinigan Black cathode catalyst. Short-term single-cell evaluation of sections cut from these electrodes $(2-3 / 4$ " $\times 2-3 / 4$ " active area) showed an IR-free voltage of $0.724 \mathrm{~V}$ at $191^{\circ} \mathrm{C}$ and $161 \mathrm{~mA} / \mathrm{cm}^{2}, \mathrm{H}_{2} / \mathrm{air}$, a performance similar to that obtained with $10.7 " \times 14 "$ electrodes.

The assessment of more corrosion-resistant cathode carbon support materials then shifted to Gulf Acetylene Black (GAB) as a possible replacement for Shawinigan Black, which became obsolete. $A$ cathode using $E_{-}-3$ catalyst on $G A B$ was tested in a single-cell. This cell showed a peak performance of $0.711 \mathrm{~V}$ IR-free $\left(161 \mathrm{~mA} / \mathrm{cm}^{2}\right.$, $191^{\circ} \mathrm{C}, \mathrm{H}_{2}$-air) after about 600 hours, but it was evident that the optimum electrode structure had not yet been achieved with this catalyst. Performance was $0.686 \mathrm{~V}$ (same conditions) at shut-down after about 2650 hours on load. GAB later became the standard cathode carbon support.

\section{Cathode Wetproofing}

A single-cell test in which variations in cathode hydrophobicity were examined (See Appendix 3) was carried out. While peaking at about $0.705 \mathrm{~V}$ (IR-free, $161 \mathrm{~mA} / \mathrm{cm}^{2}, 191^{\circ} \mathrm{C}$ ) after 1900 hours, the cell was putting out $0.676 \mathrm{~V}$ after 4600 hours. The performance history over its 5200 hours on load is shown in Figure 80. After a significant drop at about 2000 hours, this cell ran 


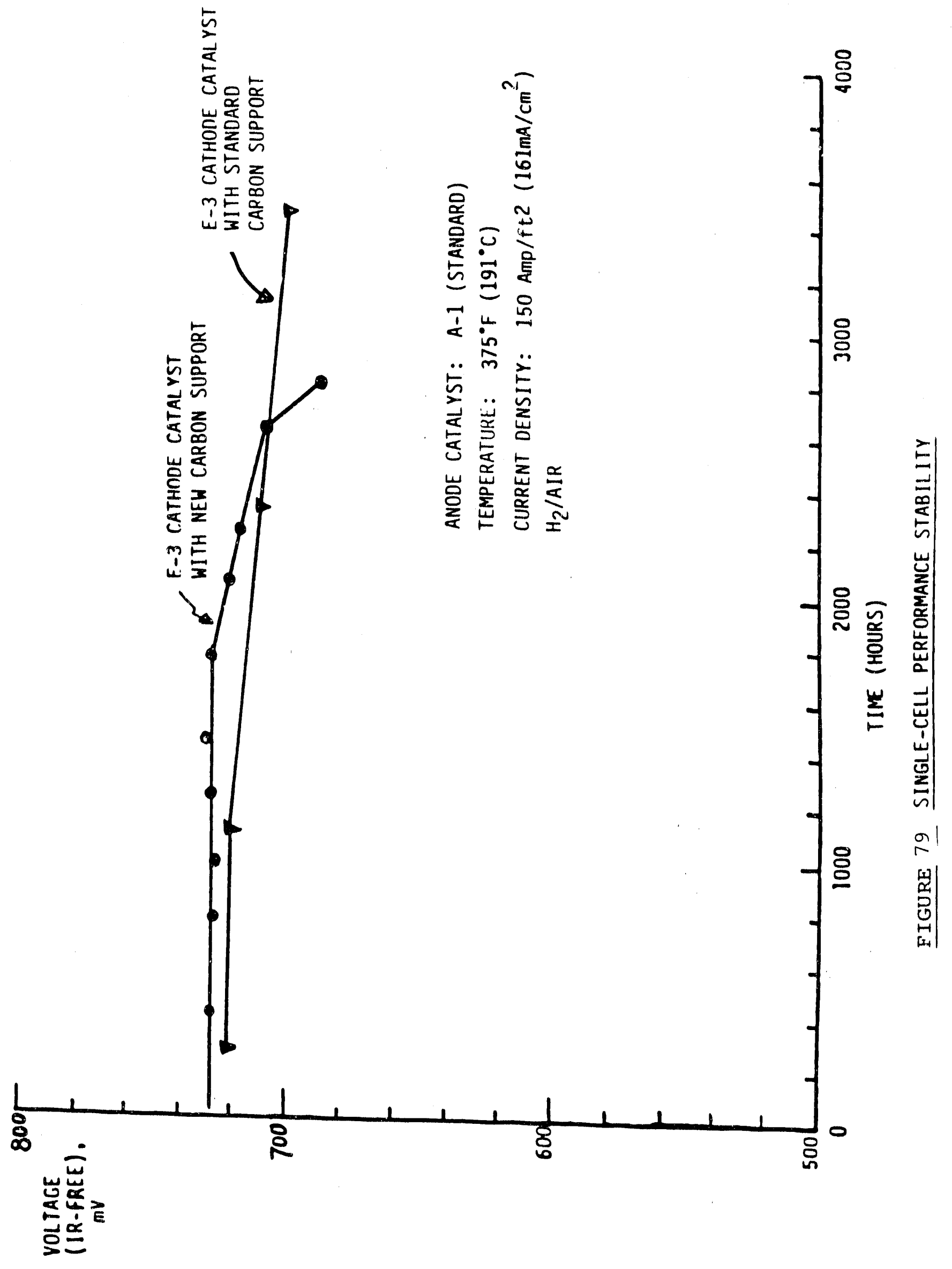




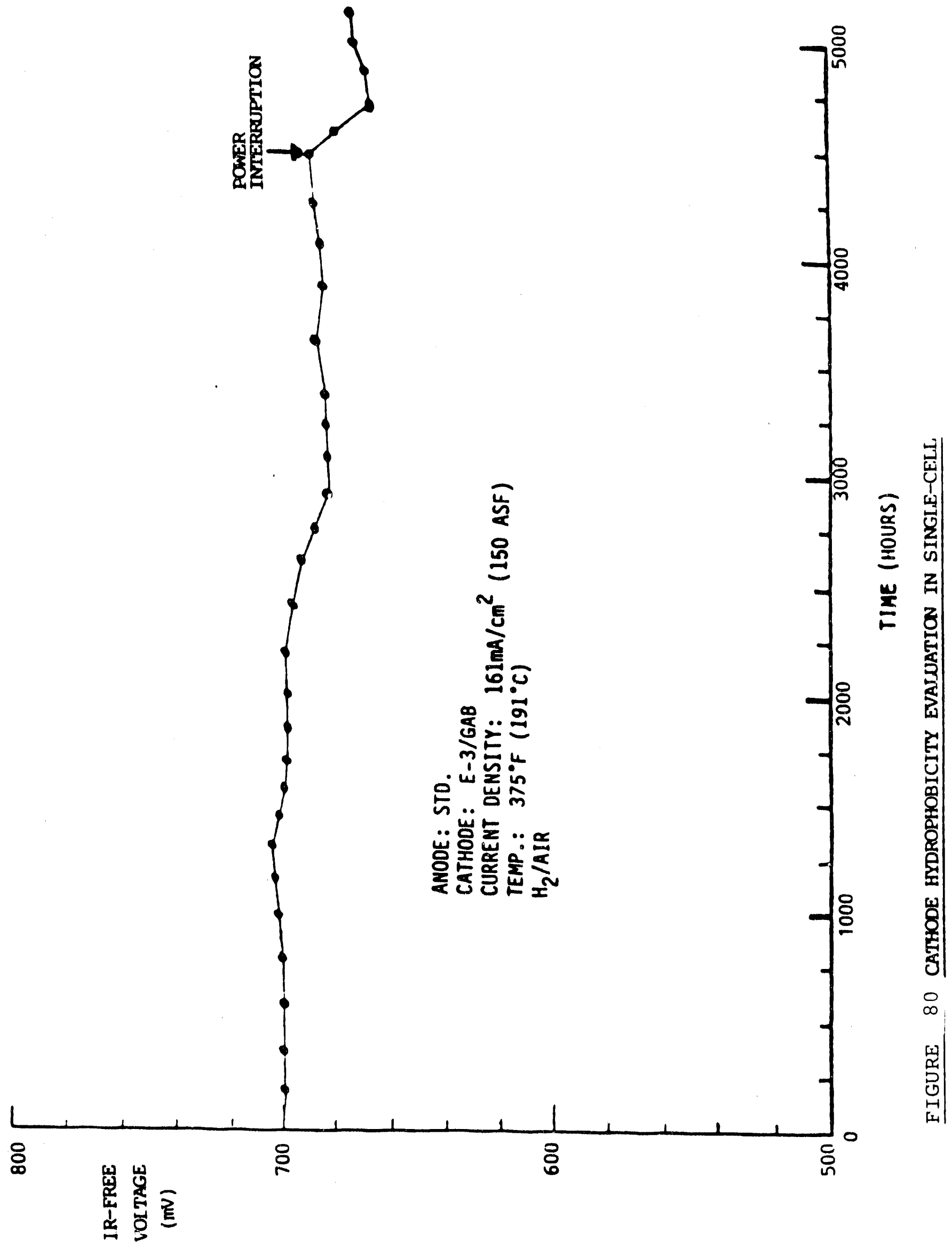


stably for quite a while at about $0.680 \mathrm{~V}$; a house power failure (resulting in a hot no-load condition) after about 4500 hours caused an additional loss in performance, as shown in Figure 81. Nevertheless, overall stability was encouraging. The cell was shut down due to a gradual build-up of corrosion products from the aluminum frame of the test fixture, which eventually blocked the entrance of the reactant air.

A second phase involving the hydrophobiclty of the cathode was subsequently carried out (See Appendix 3). Two preparations with different additives were evaluated in single cells, but an air-supply malfunction destroyed them both. one was shut down after 700 hours on load at $0.686 \mathrm{~V}$ IR-free $\left(\mathrm{H}_{2}-\mathrm{air}\right)\left(161 \mathrm{~mA} / \mathrm{cm}^{2}\right.$ and $\left.191^{\circ} \mathrm{C}\right)$, while the other was shut down after 860 hours at $0.690 \mathrm{~V}$. These techniques require further investigation.

\section{Automated Electrolyte Replenishment System}

1983 stack No. $3(11-\operatorname{cell}, 10.7$ in. $x 14$ in.) ran successfully for 6900 hours on load with the automated electrolytereplenishment system previously demonstrated in 1983 stack No. 1 . Figure 88 shows the open-circuit voltage history.

\section{Gas and Coolant Manifolds}

Testing of the two 198425 -cell stacks showed the need for improvements in protecting the manifolds. The proposed improvements fell into three categories: better corrosion resistance, periodic removal of excess phosphoric acid, and replaceability of vulnerable parts.

Corrosion resistance was improved by switching, wherever possible, from Teflon-coated aluminum, copper, brass, or low carbon steel to Teflon-coated Type-316 stainless steel, a material which has shown much better resistance to phosphoric acid corrosion than any of the other base metals used so far. The coolant manifolds were further protected by moving them from the hydrogen exhaust manifold to the hydrogen inlet manifold in the $25 \mathrm{~kW}$ stack. To avoid interfering with the baffles that distribute the flow of fuel gas to the cells, the main portion of the coolant manifolds was placed outside the fuel manifold.

Acid tends to accumulate at the bottoms of the gas manifolds, causing corrosion. To prevent this, the manifold bottoms of the $25 \mathrm{~kW}$ stack were provided with removable trays from which acid could be periodically drained. The trays can be replaced from time to time at minimum cost and lost time.

\section{Stack Start-Up and Shut-Down}

Thermal cycling of single-cells was successfully carried out. 


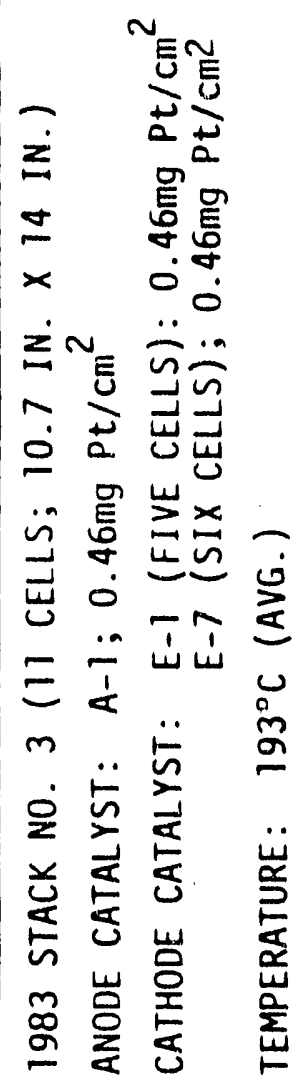

$\odot$

$\odot$

$\odot$

$\odot$

$\odot$

(

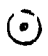

$\odot$

$\odot$

$\odot$

○

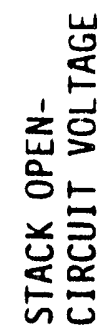

(

$\odot$ $\odot$ 
The main precautions shown to be required were a continued supply of $105 \% \mathrm{H}_{3} \mathrm{PO}_{4}$ and the presence of an electrical load at any temperature higher than $270^{\circ} \mathrm{F}$. These cycling tests were partly the basis for the following start-up and shutdown procedures which were used on the $25 \mathrm{~kW}$ stack:

Rated Coolant Flow:

Coolant Temperature:

Control Mechanism:

Start-up Procedure:
$125 \mathrm{ml} / \mathrm{s}$
$175 \pm 10^{\circ} \mathrm{C}$
Thermocouple at the stack turns heat exchanger fan on and off to maintain a stack temperature of about $195^{\circ} \mathrm{C}$.

(1) Turn coolant pump on.

(2) Heat coolant with start-up burner to $140^{\circ} \mathrm{C}$ while stack is on nitrogen.

(3) Turn reactant gases (reformate and air) on, nitrogen off, and set stack current to 25 A.S.F.

(4) Raise temperature to $160^{\circ} \mathrm{C}$.

(5) Raise stack current to 50 A.S.F.

(6) Raise temperature to $175^{\circ} \mathrm{C}$.

(7) Raise stack current to 75 A.S.F.

(8) Raise temperature to $195^{\circ} \mathrm{C}$ and keep those settings for about one day. 
(9) Rajise stack current to 150 A.S.F. and keep the temperature at about $195^{\circ} \mathrm{C}$.

Shutdown Procedure:

(1) Set stack current to 50 A.S.F.

(2) Immediately lower stack temperature to $160^{\circ} \mathrm{C}$.

(3) Lower stack current to 25 A.S.F.

(4) Lower stack temperature to $140^{\circ} \mathrm{C}$.

(5) Turn reactant gases off and nitrogen on.

(6) Lower stack temperature to $125^{\circ} \mathrm{C}$ (for hot standby) or cool down to room temperature (for complete shutdown).

A five-cell, 10.7" $x 14 "$ stack designed to examine the effectiveness of the shutdown/start-up procedure ran for about 2200 hours, including six room-temperature shutdowns. The loss from peak performance was similar to the loss pattern in stacks not subjected to periodic shutdowns. The history of this stack is shown in Figure 82 .

\section{Single Cell Life Test Fixtures}

A fixture in which the aluminum body was replaced by Type 316 stainless steel was used in single-cell testing to allow more meaningful long-term tests to be conducted without the complicating effects of fixture corrosion. This fixture showed no sign of corrosion after a test of 1800 hours duration and two additional, shorter-term runs. Type 316 stainless steel fixtures later became standard equipment in the fuel cell stations.

\section{Dry Five-Cell stack}

A dry five-cell stack ( 10.7 inches $x 14$ inches) was built to test the feasibility of acid-filling after assembly. After this stack had been preheated to $215^{\circ} \mathrm{F}$, $105 \% \mathrm{H}_{3} \mathrm{PO}_{4}$ was added to each individual cell through the acid-reservoir wicks and Kureha paper (acid-transport layer) shelves. (See Figure 83). The rate of 


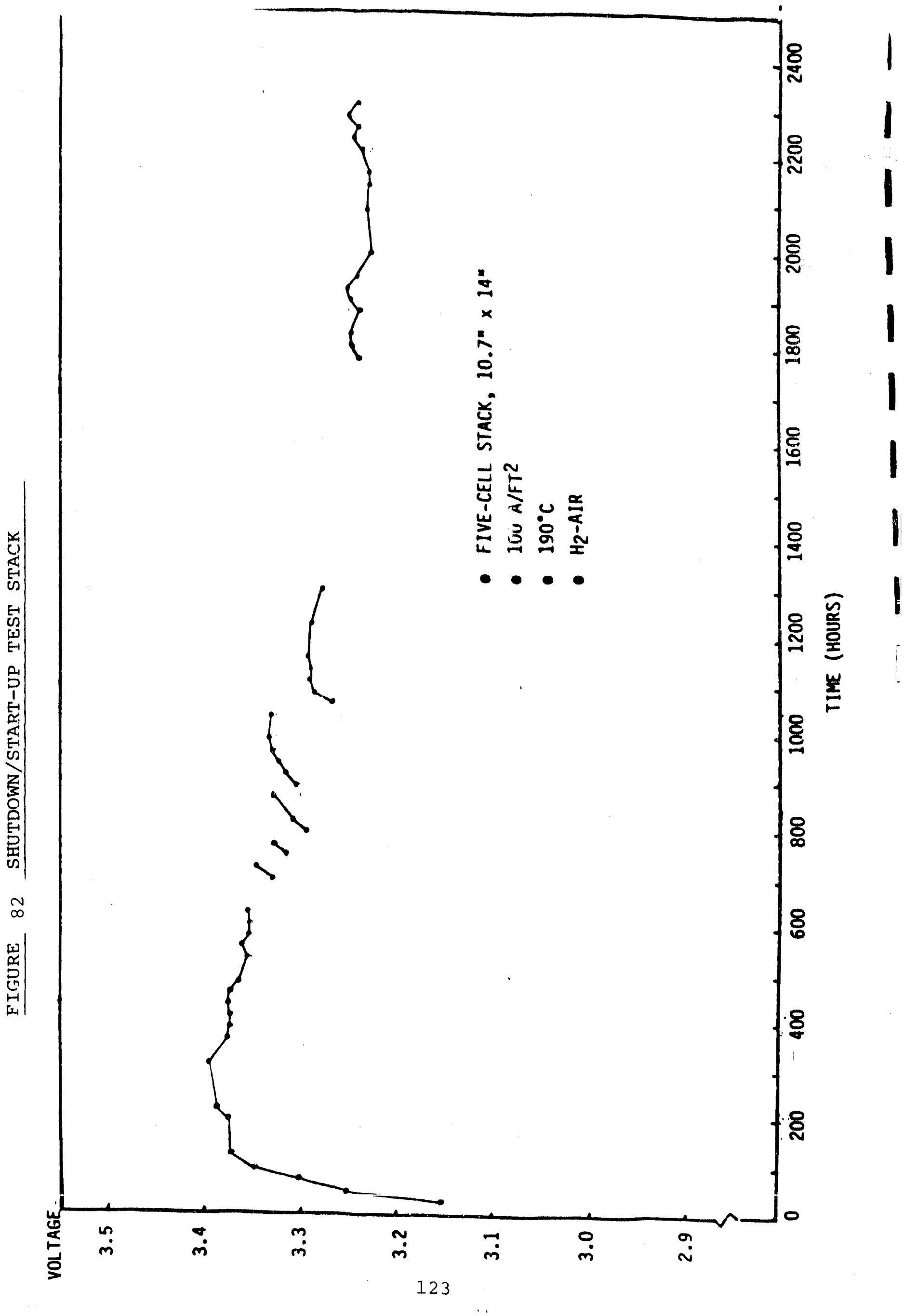



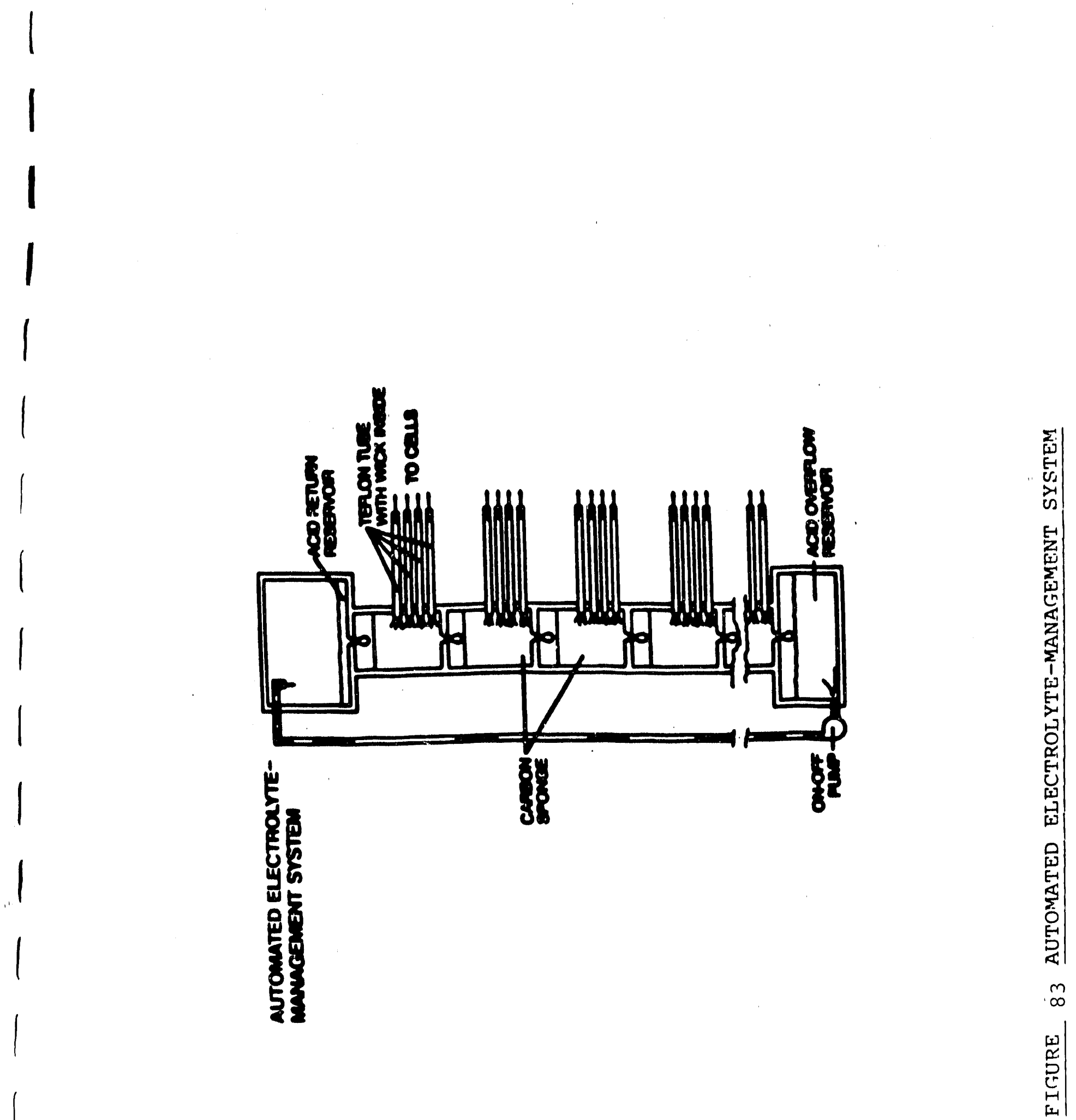
acid uptake by the stack is shown in Figure 84 : the total acid uptake was essentially the same as what would have been charged during stack assembly in a standard construction. Load was applied when the acid uptake reached about $80 \%$ of this level.

The stack ran for about 500 hours on load. For the first 350 hours, it used hydrogen fuel; the average cell voltage was about $0.64 \mathrm{~V}\left(161 \mathrm{~mA} / \mathrm{cm}^{2}, 191^{\circ} \mathrm{C}\right)$, close to what is typical for the standard stack construction (as was the average open-circuit voltage of $0.86 \mathrm{~V}$ per cell). The remainder of the test used simulated reformate fuel $\left(1 \% \mathrm{CO}, 24 \% \mathrm{CO}_{2}, 75 \% \mathrm{H}_{2}\right)$ at a hydrogen utilization rate of $80 \%$. The average $\mathrm{H}_{2}$-gain was $28 \mathrm{mV}$; this was a few millivolts higher than typical, and was attributed to several hours of hot, no-load exposure as the result of a house power failure. These results were encouraging, suggesting that far greater flexibility was feasible in the assembly and transport of fuel cell stacks.

\section{TASK V - FUEL PROCESSING SUPPORT}

The intent of this task was to provide background data to support the design and construction of an optimized methanol fuel processor under Task III. Most of this task was devoted to screening and longevity testing of catalysts for methanol/steam reforming. The task was described and discussed in Engelhard's Interiin Report for the period February 1981 - January 1984 .

\section{TASK VI - IMPROVED ELECTROCATALYSTS}

Developmental electrocatalyst formulations were prepared under Engelhard sponsorship. These were provided to the main program and results reported under Task IV.

Development work was pursued on both cathode and anode catalysts; however, the focus was mainly on improved cathode activity (See Task IV). 


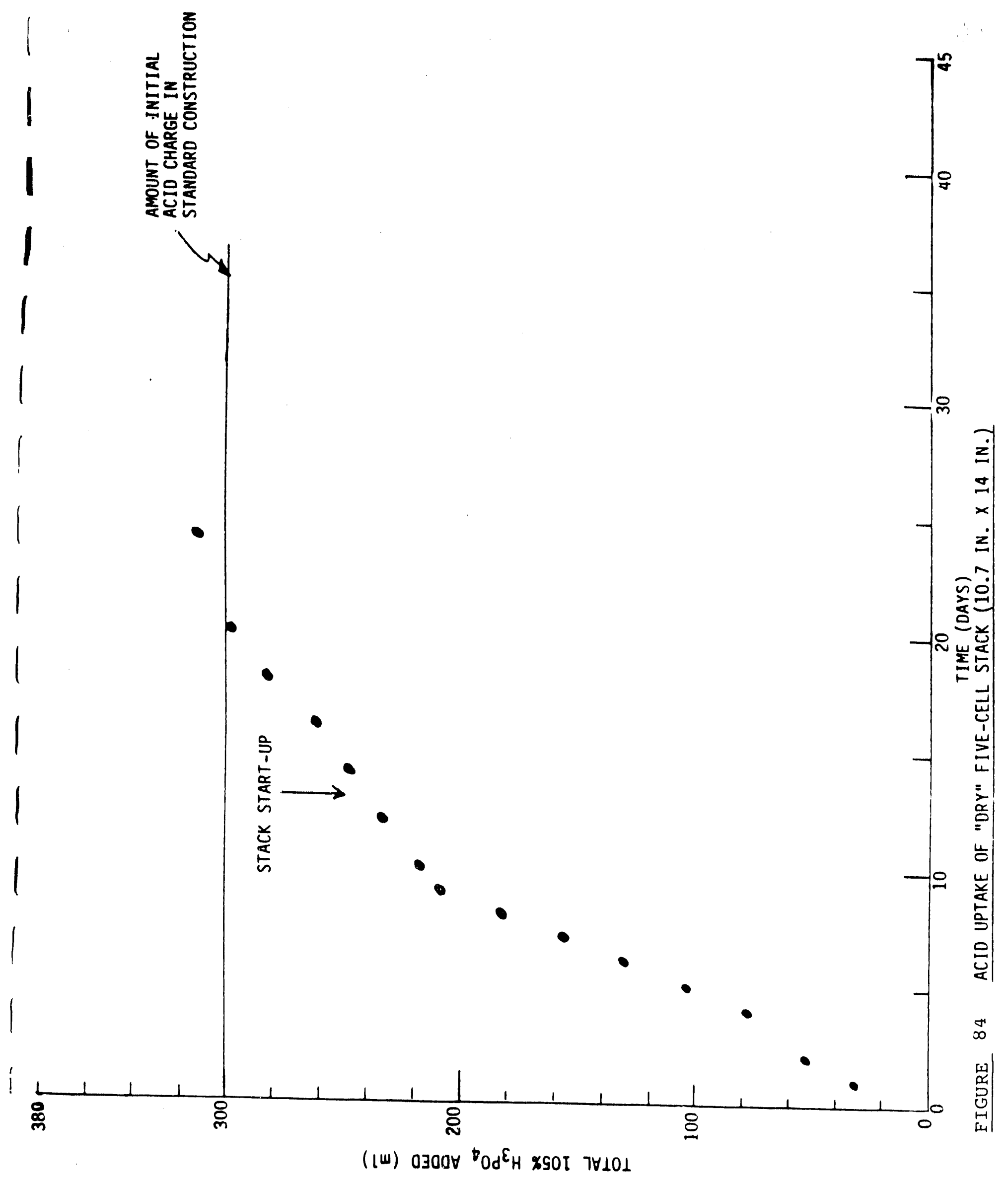



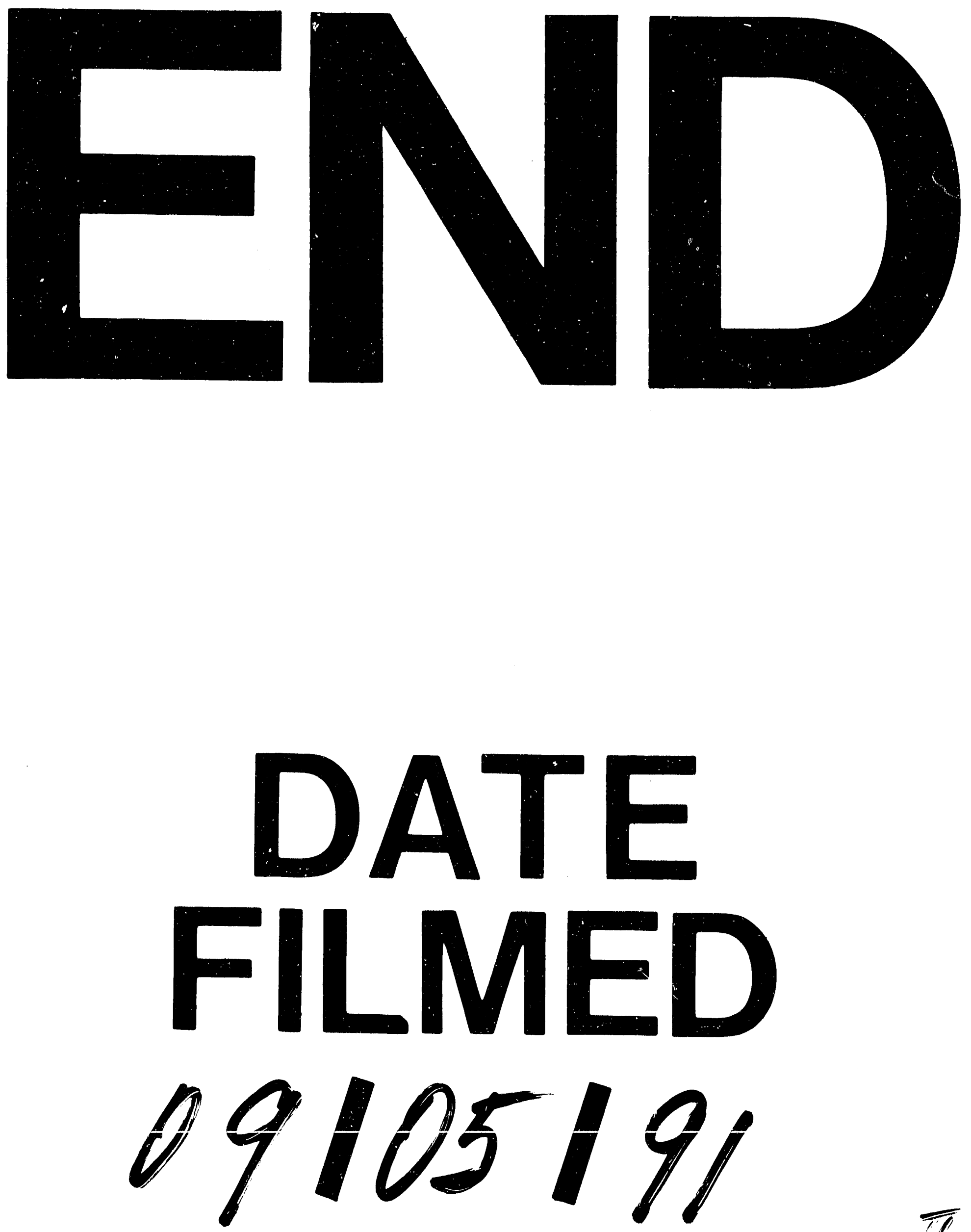
